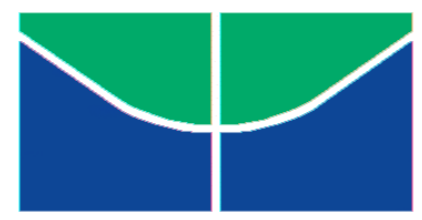

Universidade de Brasília Faculdade de Educação

Programa de Pós-Graduação em Educação

\title{
INTERAÇÃO SOCIAL E NEURORREABILITAÇÃO DE ADOLESCENTES COM LESÃO CEREBRAL: UM ESTUDO EXPLORATÓRIO EM TORNO DA REDE SOCIAL 5DNET DA REDE SARAH DE HOSPITAIS DE REABILITAÇÃO
}

Doutoranda: Luciana de Souza Pinto Alvarenga Rossi

Orientador: Professor Doutor Gilberto Lacerda Santos

Brasília 


\section{INTERAÇÃO SOCIAL E NEURORREABILITAÇÃO DE ADOLESCENTES COM LESÃO CEREBRAL: UM ESTUDO EXPLORATÓRIO EM TORNO DA REDE SOCIAL 5DNet DA REDE SARAH DE HOSPITAIS DE REABILITAÇÃO}

Tese apresentada ao Programa de PósGraduação em Educação da Universidade de Brasília - UnB, como requisito parcial para a obtenção do título de Doutora em Educação, na área de confluência Educação, Tecnologias e Comunicação, sob a orientação do Professor Doutor Gilberto Lacerda Santos.

Brasília-DF 

Rossi, Luciana de Souza Pinto
Alvarenga RR831i INTERAÇÃO SOCIAL E NEURORREABILITAÇÃO DE

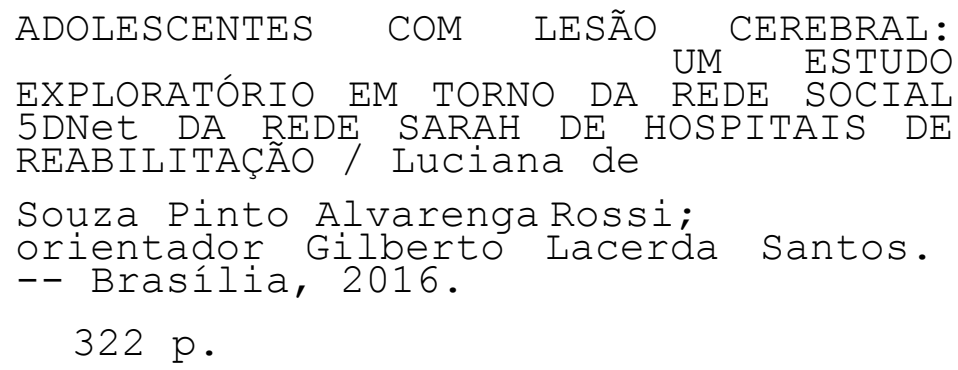


Universidade de Brasília

Faculdade de Educação

Programa de Pós-Graduação em Educação

TESE DE DOUTORADO

INTERAÇÃO SOCIAL E NEURORREABILITAÇÃO DE ADOLESCENTES COM LESÃO CEREBRAL:

UM ESTUDO EXPLORATÓRIO EM TORNO DA REDE SOCIAL 5DNet DA REDE SARAH DE HOSPITAIS DE REABILITAÇÃO

\section{Luciana de Souza Pinto Alvarenga Rossi}

Orientador:

Dr. Gilberto Lacerda Santos

Banca examinadora:

Dr. Marcelo Giordan Santos-USP Dr $^{\mathrm{a}}$ Lucia Willadino Braga- Rede Sarah de Hospitais

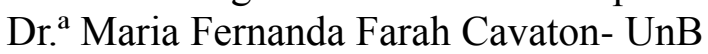

Dr. Carlos Lopes - UnB

Dr. Lúcio França Teles-UnB 
DEDICATÓRIA

Aos meus pais (in memoriam) 


\section{AGRADECIMENTOS}

Ao Francisco, meu companheiro incondicional.

Ao Pedro, meu filho e minha maior força.

Ao meu grande amigo e orientador, Gilberto Lacerda, com quem muito aprendi sobre a arte de seguir em frente nos tortuosos caminhos das novas descobertas. Muito obrigada pela supervisão técnica, pelos ensinamentos e apoio pessoal.

À Lucia Braga pelas discussões, apoio ao projeto e amizade de tantos anos.

À Vera Lawisch pela compreensão de todos os dias.

Ao Flavio Bercott por me salvar no último minuto.

Ao estatístico Sandro Barbosa pela ajuda nas análises.

À bibliotecária Luciana Sollaci pelo apoio.

A toda equipe do projeto 5D: adolescentes, alunos de graduação e profissionais da Rede Sarah, pelo trabalho conjunto.

A todos os pesquisadores e colegas do Laboratório Ábaco pelas novas descobertas.

A toda equipe e alunos da Pós-Graduação da Faculdade de Educação da UNB, muito obrigada. 


\section{RESUMO}

Os programas educacionais de reabilitação devem ser acomodados aos diferentes interesses e etapas da vida e procurar incorporar ferramentas mediadoras que sejam significativas para novas aprendizagens. Este estudo teve por objetivo criar uma rede social como estrutura de apoio e expansão do sistema educacional Quinta Dimensão (5D) voltada para a reabilitação de pré-adolescentes e adolescentes com lesão cerebral. O sistema educacional 5D é fundamentado na teoria histórico-cultural da atividade e em conceitos da aprendizagem colaborativa, bases teóricas aplicadas à rede social desenvolvida, nomeada 5DNet. Construído sobre os princípios metodológicos da pesquisa ação, participaram deste projeto educacional e de investigação alunos de graduação em psicologia e pedagogia e adolescentes com lesão cerebral. A implantação da rede social 5Dnet foi avaliada segundo parâmetros da Análise de Redes Sociais (ARS) e análise de conteúdo, a partir de dados qualitativos levantados juntos aos seus usuários. Os resultados comprovam a hipótese de expansão educacional da aprendizagem e de ressignificação do objeto da atividade. Demonstraram uma nova ecologia para a aprendizagem intergeracional; para a aprendizagem colaborativa; apontam repercussões na comunicação com a utilização da linguagem multimodal; e fornecem parâmetros para reabilitação das funções executivas de autoregulação, pensamento metacognitivo e planejamento a partir do uso compartilhado da rede social implantada.

Palavras chave: adolescência; lesão cerebral; sites de redes sociais; reabilitação 


\begin{abstract}
Educational rehabilitation programs should be compliant with an individual's interests and life stages, and should include meaningful mediation tools conducive to new learning and acquisitions. The goal of this study was to create a social network as a system for supporting and expanding the Fifth Dimension ("5D") Educational Program, which is dedicated to the rehabilitation of pre adolescents and adolescents with brain injury. The 5D educational system is founded on the cultural-historical theory of activity and collaborative learning concepts; these theoretical bases were applied to the new 5DNet social network. This educational and investigative project was built on methodological principles of action research. It involved undergraduate college students majoring in Psychology and Teaching, as well as teenagers with brain injury. The implementation of the 5DNet was evaluated according to the parameters set forth by the Social Networks Analysis (ARS) and was based on qualitative data gathered from the network's users. The results proved the hypothesis of educational learning expansion and the reassignment of meaning to activity goals. The outcomes of the study included the demonstration of a new ecology for intergenerational learning; for collaborative learning; and repercussions in communication with multimodal language. It also provided parameters for rehabilitating the executive functions of selfregulation, metacognitive thought, and planning, based on the shared use of this new social network.
\end{abstract}

Key words: adolescence; brain injury, social networking sites; rehabilitation 


\section{RÉSUMÉ}

Les programmes éducatifs de réhabilitation doivent s'accommoder aux différents intérêts et aux différentes étapes de la vie, cherchant à intégrer des outils de médiation qui aient un rôle significatif dans le développement de nouveaux apprentissages. Cette étude a eu pour but la création d'un réseau social fonctionnant comme une structure de support et d'expansion du système éducatif Quinta Dimensão (5D) orienté vers la réhabilitation des pré-adlescents et d'adolescents atteints d'une lésion cérébrale acquise. Le système éducatif 5D s'appui sur la théorie historico-culturelle de l'activité et sur des concepts de l'apprentissage collaboratif, celles-ci étant les bases théoriques appliquées au réseau social 5DNet. Conçu sur les principes méthodologiques de la recherche-action et de l'analysen de contenu, ce projet éducatif et de recherche a compté sur la participation de stagiaires des facultés de psychologie et d'éducation et d'adolescents cérébro-lésés. La mise en place du réseau social 5DNet a été évaluée selon les paramètres de l'Analyse de Réseaux Sociaux (ARS) et à partir de données qualitatives collectées auprès de ses usagers. Les résultats obtenus attestent l'hypothèse de l'expansion éducative de l'apprentissage et de la resignification de l'objet de l'activité. Ils attestent aussi la réussite concernant l'établissement d'une nouvelle écologie pour l'apprentissage intergénérationnel; pour l'apprentissage collaboratif; ils indiquent des effets positifs sur la communication avec l'utilisation du langage multimodal; et fournissent des paramètres pour la réhabilitation des fonctions exécutives d'autorégulation, de pensée métacognitive et de planification à partir de l'utilisation partagée du réseau social mis en place.

Mots clés: adolescence ; lésion cérébrale ; sites des réseaux sociaux ; réabilitation 


\section{Lista de figuras}

Figura 1 - Visão Geral Esquemática do Labirinto e outros artefatos 5D

Figura 2 - Linha do tempo dos principais sites de rede sociais, 1996-2014.................. 74

Figura 3 - Plano de ação para criação da Rede Social...................................................... 87

Figura 4 - Layout do Blog 5DLog indexado ao labirinto, 2010 .................................. 102

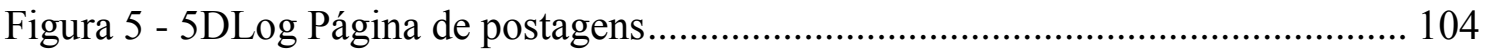

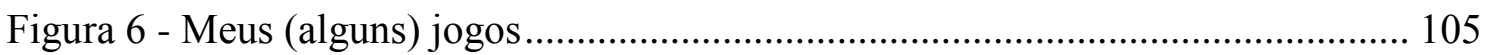

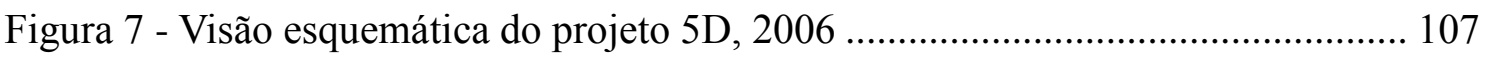

Figura 8 - Visão esquemática da expansão do projeto 5D com a rede social 5DNet, 2015

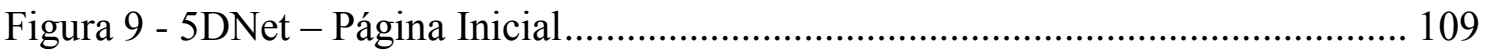

Figura 10 - Conexões da Rede Social 5DNet .............................................................110

Figura 11 - Centralidade da Rede Social 5DNet ......................................................114

\section{Lista de Tabelas}

Tabela 1 - Revisão da literatura: redes sociais e reabilitação......................................... 54

Tabela 2 - Grade de Horários 5D na Rede Sarah de Hospitais.................................... 90

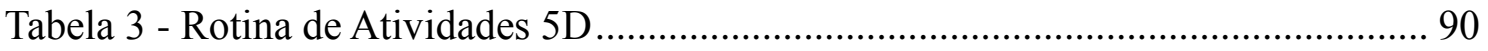

Tabela 4 - Descrição das categorias de estudo .............................................................. 98

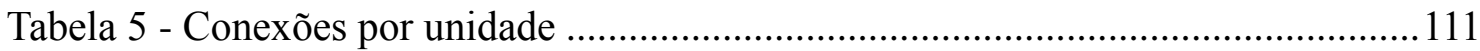

Tabela 6 - Adolescentes com maior grau de centralidade .........................................114 
Tabela 7 - Estagiários com maior grau de centralidade ...............................................114

Tabela 8 - Caracterização dos participantes adolescentes ...........................................116

Tabela 9 - Caracterização dos participantes estagiários ...............................................118

Tabela 10 - Análise descritiva dimensão interatividade: adolescentes e estagiários .... 120

Tabela 11 - Análise descritiva dimensão educação: adolescentes e estagiários ............ 133

Tabela 12 - Análise descritiva dimensão função executiva: adolescentes e estagiários 144 


\section{SUMÁRIO}

1. A adolescência e o adolescente com lesão cerebral: alguns desafios......... 14

2. Projeto Quinta Dimensão: uma alternativa educacional ............................. 22

2.1 Fundamentos teóricos do projeto 5D: Teoria Histórico-Cultural da Atividade ....... 25

2.2 A origem social do pensamento ....................................................................... 28

2.3 Zona de desenvolvimento proximal: elemento central no sistema educacional 5D... 30

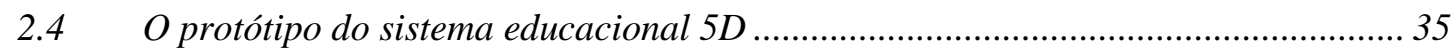

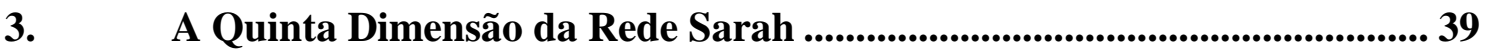

3.1 Adaptações nos artefatos da atividade ............................................................. 40

3.2 Ajustes no sistema educacional ............................................................... 41

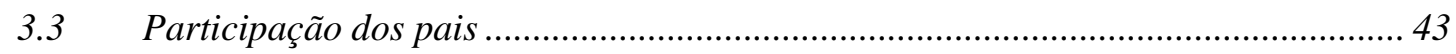

3.4 Desenvolvimento de um projeto de estágio para os alunos de graduação............... 45

4. A expansão da 5D: o problema de estudo ....................................................... 48

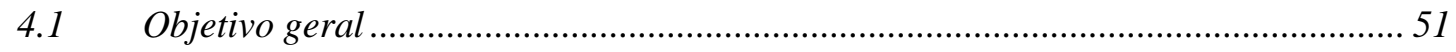

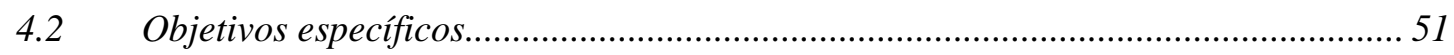

5. Rede social, educação e reabilitação .......................................................... 52

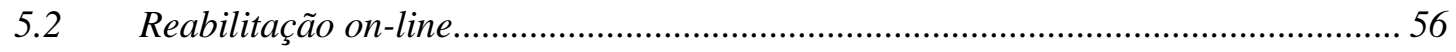

5.3 Padrões de uso, segurança e educação ................................................................. 58

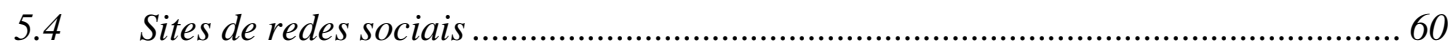

6. Sites de redes sociais: estrutura, história e aplicação em educação .......... 65

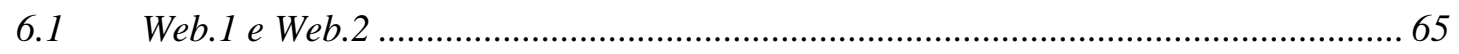

6.2 A estrutura e as especificidades dos sites de redes sociais.................................... 68

6reve história dos sites de redes sociais..................................................... 72

Sites de redes sociais educacionais ............................................................... 77

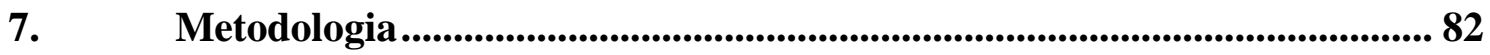




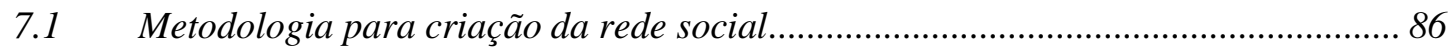

7.1.1 Organização do ambiente e material educacional ..................................................... 88

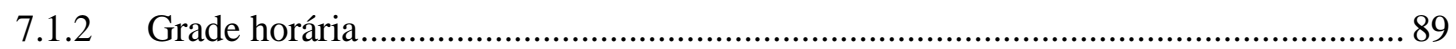

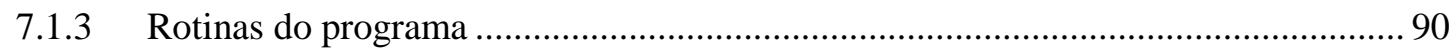

7.1.4 Diretrizes iniciais de uso da rede social no contexto 5D .......................................... 91

7.2 Metodologia para avaliação da rede social .............................................................. 91

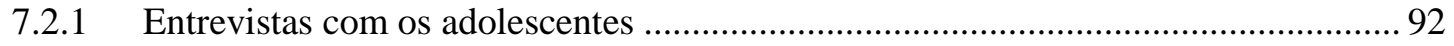

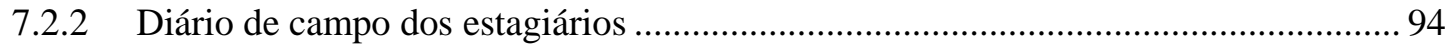

7.3 Procedimento de análise das entrevistas dos adolescentes e diários de campo dos

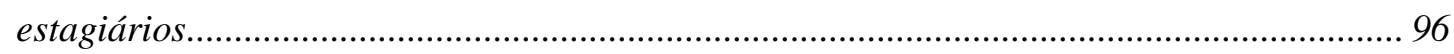

8. Análise e discussão dos dados .................................................................... 100

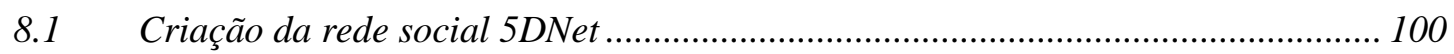

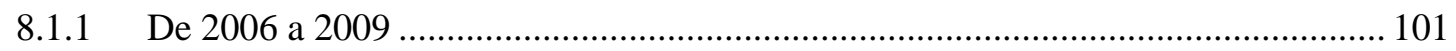

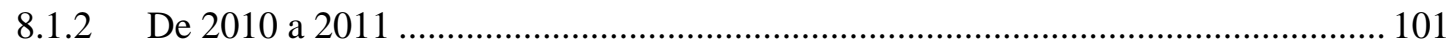

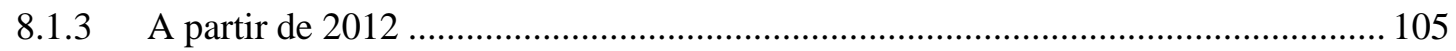

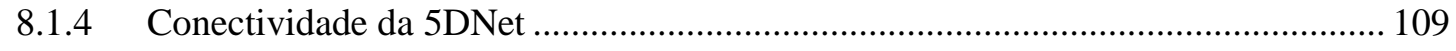

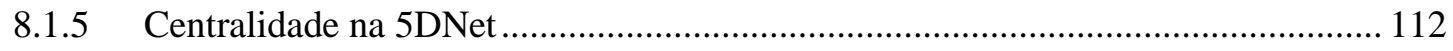

8.2 Caracterização da amostra para análise da rede social.........................................115

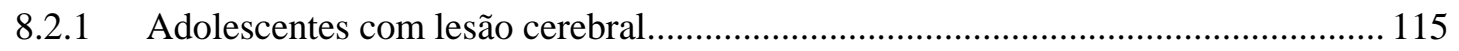

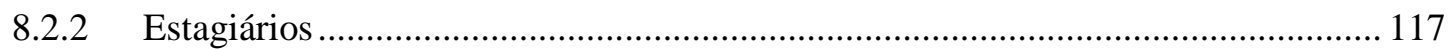

8.3 Avaliação dos usuários da 5DNet adolescentes com lesão cerebral e estagiários. 119

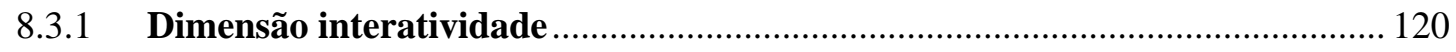

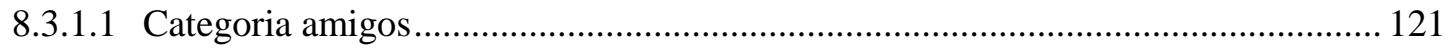

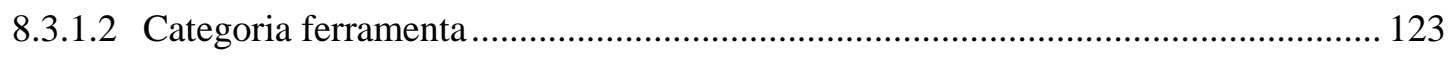

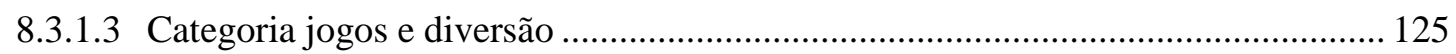

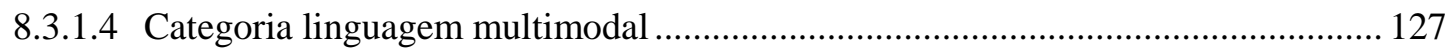

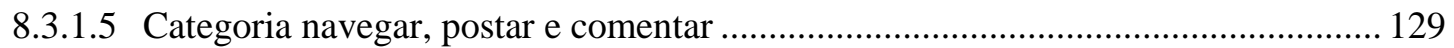




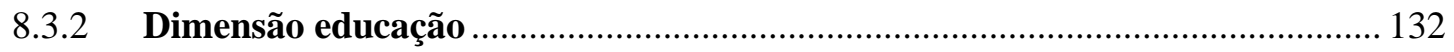

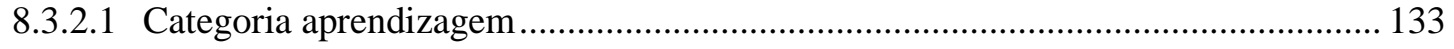

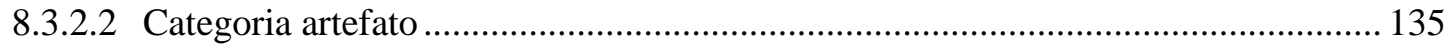

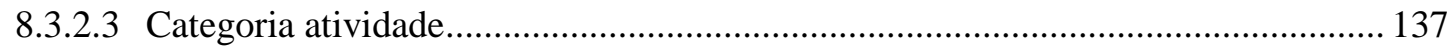

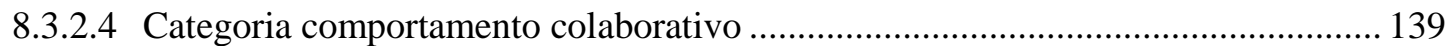

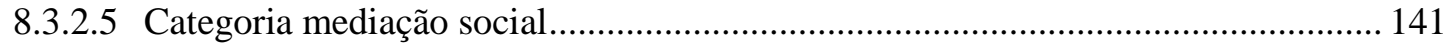

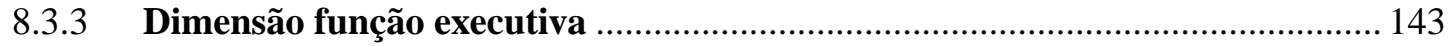

8.3.3.1 Categoria autorregulação.................................................................................. 145

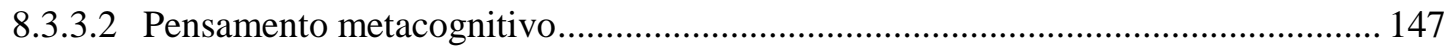

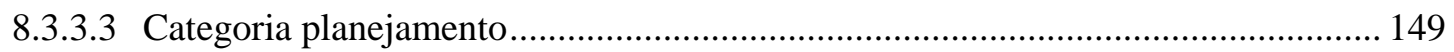

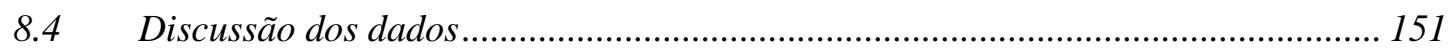

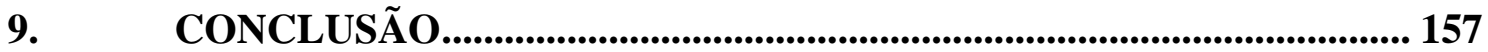

REFERÊNCIAS BIBLIOGRÁFICAS ...................................................................... 164

APÊNDICE A - ENTREVISTA ESTUDANTES .............................................. 170

APÊNDICE B - ENTREVISTA ADOLESCENTES ................................................... 221 


\section{A ADOLESCÊNCIA E O ADOLESCENTE COM LESÃO CEREBRAL: ALGUNS DESAFIOS}

O presente estudo tem como objetivo central a criação de uma rede social como estrutura de apoio e de expansão de um sistema educacional voltado para a reabilitação de adolescentes com lesão cerebral. Trata-se, portanto, de um estudo que se situa no âmbito das aplicações pedagógicas das tecnologias digitais de informação, comunicação e expressão, no contexto da pedagogia clínica, e que tem como foco os adolescentes.

A palavra "adolescência" vem do latim adelesco, que significa "crescer". As mudanças físicas, biológicas e psicológicas associadas à puberdade têm um significado social tanto para os jovens quanto para sua comunidade e variam com os contextos culturais e as características individuais. O início da adolescência, que ocorre em torno da puberdade, é caracterizado por alterações significativas nos níveis hormonais e na aparência física. Esse período de vida também é marcado pelo desenvolvimento das habilidades sociais e comportamentais, bem como pela maturação neurofisiológica nas regiões do cérebro envolvidas na cognição social (COLE M; COLE S, 2004; GODDINGS et al., 2012).

A compreensão de como se desenvolvem as habilidades sociais no fim da segunda infância e início da adolescência é relativamente recente (BURNETT; BLAKEMORE, 2009), ainda que as pesquisas na área da Psicologia Social sobre a adolescência tenham se desenvolvido muito nos anos 1970, a investigação a respeito dos processos mentais e os componentes subjacentes aos comportamentos sociais complexos não foram tão explorados(GODDINGS et al., 2012). Neste momento de transição uma série de habilidades cognitivas comportamentais continuam a se desenvolver e aprimorar com o convívio social, com a maturação e a poda neurológica 
(BLAKEMORE, 2010). Nesta fase, os adolescentes aprimoram a capacidade para compreender a perspectiva emocional do outro, colocando-se no lugar dos seus amigos, conseguem perceber pequenos sinais da expressão facial das emoções e optar por valorizar ou não a opinião de terceiros (COLE M; COLE S, 2004).

O inicio da adolescência também marca mudanças nos padrões do comportamento social. $\mathrm{Na}$ adolescência, há um interesse crescente nas relações entre pares: os adolescentes gastam muito mais tempo com os amigos com quem se identificam e, consequentemente, menos tempo com a família. Gradualmente aprofundam suas relações, níveis de compromisso, intimidade e aceitação das diferenças entre amigos. Surge assim uma identidade social mais integrada com diferentes tipos de relacionamentos.

A hipótese projetada de perda de intimidade entre os adolescentes em função da urbanização e outros processos sociais não se concretizou (KON, IGOR; LOSENKOV, 1978). A facilidade de mobilidade, as tensões da vida cotidiana nas grandes cidades e a expansão dos ciclos de amizade com o advento das redes sociaisonline, ao invés de tornarem as amizades mais superficiais, aumentaram a possibilidade de escolha individual e fortaleceram as necessidades psicológicas individuais de intimidade. O que muda neste novo desenho são as normas sociais de como se apresentar e fazer negociações, uma vez que a identificação pública envolve outro tipo de habilidade e percepção social. Embora os jovens negociem e renegociem constantemente as normas para a exibição de amizade e as práticas sociais subjacentes nas redes sociais na internet, os comportamentos online considerados socialmente adequados refletem, em grande parte, o que é apropriado e aceito em contextos off-line como na escola, em clubes, no bairro, entre outros (MIZUKO, 2009). 
O processo de crescimento e de construção do comportamento independente requer que a família flexibilize suas fronteiras, de modo a permitir ao adolescente vivenciar situações novas e negociar seus interesses com segurança e responsabilidade sobre suas próprias ações. Muitas vezes isso implica na participação em situações consideradas de maior vulnerabilidade. Jogos eletrônicos têm sido utilizados para testar o comportamento de adolescentes em situações potencialmente perigosas como, por exemplo, em jogos de direção. Na presença de amigos, os adolescentes, e em menor extensão os jovens adultos, tendem a assumir mais riscos durante a condução, como não parar em um semáforo amarelo. Por outro lado, estes níveis não aumentam quando os adolescentes estão sozinhos (BURNETT; BLAKEMORE, 2009).

Apesar dos esforços de pais, escolas e órgãos públicos para educar os adolescentes e fornecer-lhes informações preventivas, muitos continuam a se envolver em situações de exposição. Acredita-se muitas vezes que os adolescentes se envolvem em comportamentos limite porque não sabem dimensioná-los e avaliá-los. No entanto, estudos demonstram que os adolescentes são tão bons quanto os adultos na avaliação do risco através de uma ampla gama de comportamentos (STEINBERG, 2007). Varias mudanças na fisiologia do cérebro durante a puberdade explicam este comportamento. Nos últimos anos, tem havido um aumento considerável de estudos de imagem cerebral usando a ressonância magnética funcional (fMRI). Estes estudos demonstram que várias áreas do cérebro tornam os adolescentes mais sensíveis às recompensas ocasionadas por relacionamentos com seus pares do que os adultos (STEINBERG, 2007). Isso motiva os adolescentes a se concentrar em seus pares em situações de tomada de decisões.

Além disso, os adolescentes ficam mais ansiosos e agitados do que os adultos quando excluídos pelos colegas (GODDINGS et al., 2012). A região do cérebro conhecida como córtex pré-frontal é importante para ajudar as pessoas a lidar com a 
avaliação negativa de seus pares, a auto regulação do comportamento e a tomada de decisão. No entanto, durante a adolescência, esta região do cérebro ainda está em desenvolvimento de modo que os adolescentes podem não ser tão eficazes no controle do desconforto durante a exclusão social de pares. Isso provavelmente contribui para engajarem-se em comportamentos de vulnerabilidade e exposição, sobretudo para evitar este tipo de exclusão (BLAKEMORE, 2010).

Adquirir uma lesão cerebral na infância ou na adolescência pode trazer consequências de longo prazo alterando em diferentes níveis o curso da aprendizagem e do desenvolvimento. Dentre os adolescentes com lesão cerebral acompanhados na Rede Sarah ${ }^{1}$, os diagnósticos mais frequentes são a paralisia cerebral e a lesão cerebral adquirida. Dados do Centro Nacional de Controle de Qualidade ${ }^{2}$ da Rede Sarah indicam que no Brasil as principais causas das lesões cerebrais na adolescência são acidentes de trânsito, acidentes com arma de fogo e atropelamento. Grande parte das lesões adquiridas nestas fases da vida é classificada como sendo de natureza leve (FORSYTH, 2010), mas, mesmo consideradas leves, uma série de alterações neuropsicológicas,

1 A Rede Sarah é constituída por 9 unidades localizadas em Brasília (duas unidades), Belo Horizonte, Salvador, Rio de Janeiro, Belém, Macapá Fortaleza e São Luís. É uma rede pública, não estatal. Tem por o objetivo oferecer assistência médica e de reabilitação qualificada e gratuita a todos os níveis da população brasileira, além de desenvolver atividades educacionais de formação, de prevenção e de pesquisa no campo da saúde, em cooperação com o poder público. As unidades da Rede Sarah estão interligadas por tecnologia de comunicação à distancia (www.sarah.br).

2 O Centro Nacional de Controle de Qualidade da Rede Sarah (CNCQ) desenvolve indicadores epidemiológicos, consolida dados estatísticos para pesquisas e análises do perfil dos usuários e atendimento na Rede. 
comportamentais e sociais em desenvolvimento podem ser interrompidas e tornar-se aparentes apenas quando o seu processo de desenvolvimento tenha sido completado ou quando crescerem as expectativas sociais destas demandas. Estudos têm demonstrado que as habilidades que estão em um rápido processo de desenvolvimento ou são ainda imaturas no momento da lesão são mais suscetíveis a seus efeitos com o passar do tempo (FORSYTH, 2010).

A extensão do impacto da lesão cerebral na infância e na adolescência ainda é desconhecido (FORSYTH, 2010) e está associado a uma série de variáveis como a história individual, fatores ambientais, educacionais, acesso a programas de reabilitação e a fisiopatologia do quadro.

As habilidades cognitivas e o comportamento social interativo são regulados por sistemas cerebrais semelhantes (YLVISAKER et al. ,2007). Existe uma interdependência entre ambos e seria muito difícil entendê-los separadamente. Muitas vezes é dada mais ênfase às questões cognitivas do que às interações entre cognição e comportamento social, ainda que as dificuldades com elementos básicos da comunicação social possam estar entre as consequências de longo prazo mais debilitantes após lesão cerebral (RYAN et al., 2013). Dentre as dificuldades de comunicação, o comprometimento nas habilidades pragmáticas, incluindo dificuldades em manter o turno de uma conversa, em ajustar a linguagem para responder às restrições de um diálogo à distância, associado a dificuldades em reconhecer dicas não verbais, são fatores que, juntos, contribuem para um ajustamento social improdutivo (ANDREWS; ROSE; JOHNSON, 1998).

No dia a dia, os adolescentes tentam unir-se a seus amigos e companheiros de escola, ou a outros grupos sociais. Entretanto, as dificuldades comportamentais sociais associadas às alterações cognitivas decorrentes da lesão cerebral podem criar um grande 
obstáculo à integração social bem-sucedida. Isso gera um ciclo: com as oportunidades reduzidas de convívio com amigos, os adolescentes vivenciam situações de isolamento social, o que irá levar, consequentemente, a uma diminuição das interações em diferentes contextos, e tudo ocorre em uma fase da vida onde a cooperação dos pares é fundamental para a autoestima. Com menos oportunidades de socialização e comunicação, funções neurocognitivas cujo desenvolvimento se aprimora na troca social ficam prejudicadas (PRIGATANO; GUPTA, 2006).

A médio prazo, o isolamento é um dos maiores problemas destes jovens. Ele ocorre de forma gradual e a sensação de perda dos amigos vem com o tempo. As dificuldades de interação e comunicação tornam-se mais evidentes durante a adolescência, exatamente no período do desenvolvimento em que se impõe o aumento da demanda das habilidades sociais.

A maneira como pensamos sobre os outros desempenha um papel importante na forma como compreendemos, sentimos e interagimos com o mundo ao nosso redor (FLAVELL, J; MILLER, P; MILLER, 1999). Para um jovem adulto que adquiriu uma lesão cerebral na infância, a redução na competência social pode provocar experiências de rejeição que reforcem uma visão pessoal negativa das suas habilidades sociais, que parecem tornarem-se divergentes dos seus pares em um período do desenvolvimento que é caracterizado pelo aumento da autonomia e da pressão para atingir metas comuns relacionadas à formação profissional, trabalho e relacionamentos adultos. A complexidade das relações sociais e a capacidade de agir apropriadamente nas diferentes situações podem contribuir para certo distanciamento dos pares e para a sua exclusão dos grupos sociais nas diferentes etapas da vida (PRIGATANO; GUPTA, 2006). O que vai caracterizar o desenvolvimento destes jovens é uma complexa interação de fatores neurobiológicos, sociais e educacionais: o fortalecimento das redes 
sociais, a redução do isolamento, reestabelecer um sentimento de pertencimento são elementos fundamentais no desenho de um projeto educacional. Talvez sejam esses os maiores desafios de programas de reabilitação, o que certamente teria uma ampla repercussão em vários domínios da vida.

A reabilitação é um contrato de vida e deveria ser pensada a partir desta perspectiva. Uma criança com lesão cerebral será um adulto com lesão cerebral $^{3} \mathrm{e}$ provavelmente precisará do acompanhamento de reabilitação de longo prazo. É preciso acomodar o projeto educacional de reabilitação às diferentes fases da vida e procurar incorporar novas ferramentas educacionais a esses programas. Um jovem não pode ficar refém de um centro de reabilitação, ele tem uma série de interesses e desafios pela frente (BRAGA, 2009). Esses interesses mudam de geração em geração, transformamse no tempo e este continuum requer muita atenção para uma intervenção sensível a estas mudanças. Os projetos de reeducação (ou educação) devem ser desenhados a partir dos interesses dos sujeitos neles envolvidos para maximizar os benefícios da abordagem e da recuperação neurológica. Um processo compreensivo de reabilitação ocorre a partir do enriquecimento do ambiente natural de vida, da valorização e do respeito aos interesses pessoais e aos valores individuais, de forma prazerosa e sustentável. Um programa deve ser integrado ao cotidiano de vida, incorporando ferramentas, linguagens, modos de comunicação e relacionamento social próprios de cada etapa do desenvolvimento, do contexto e do momento histórico. É um processo dinâmico que exige o diálogo entre as áreas da educação e da saúde, mas que ainda constitui um grande desafio a ser enfrentado.

\footnotetext{
${ }^{3}$ Comunicação pessoal: Lucia Willadino Braga, Brasília, Janeiro de 2000.
} 
Independente dos fundamentos teóricos e conceituais que sejam adotados nesta prática, a educação é o recurso fundamental para novas aprendizagens para todos aqueles que sofreram alguma alteração em seu desenvolvimento. No entanto, incorporar novas ferramentas culturais e novos valores aos programas de reabilitação é um processo árduo: muitas vezes esta área se vê impregnada pelo raciocínio médico-clínico e tende a uma compreensão monolítica do desenvolvimento humano.

Em pleno século XXI, na era das tecnologias digitais de informação, comunicação e expressão, seria muito difícil pensar em conceber o desenho de um programa educacional de reabilitação para adolescentes com lesão cerebral que não incorporasse as ferramentas sociais digitais, contemporâneas, mediadoras das interações sociais e da aprendizagem. Por outro lado, não basta reconhecer sua importância e dispor de um arsenal tecnológico sem entender como podemos utilizá-lo, estes são os nossos maiores desafios neste estudo. 


\section{PROJETO QUINTA DIMENSÃO: UMA ALTERNATIVA EDUCACIONAL}

O Projeto Quinta Dimensão (5D) foi originalmente concebido por uma equipe do Laboratório de Cognição Humana Comparada da Universidade da Califórnia, dirigido pelo professor Michael Cole. ${ }^{4}$ Antes de começarmos a apresentar os fundamentos teóricos e a detalhar o protótipo desse sistema educacional, uma descrição geral e subjetiva da atividade favorece a compreensão da sua dinâmica, sua gênese e o processo de construção do programa. Durante quase uma década, professores da Universidade da Califórnia e seus alunos de graduação reuniram-se inúmeras vezes com crianças da escola primária em vários centros de programa extraescolar, a fim de participar de uma experiência educacional incomum. Eles brincavam com vários jogos relacionados às lições de casa das crianças; os estudantes universitários e as crianças trocavam ideias sobre seu cotidiano na universidade e na escola ; escreviam uns para os

${ }^{4}$ Michael Cole é professor de Psicologia e Comunicação no Departamento de Comunicação da Universidade da Califórnia, em San Diego, e diretor do Laboratório de Cognição Humana Comparada. Desenvolveu os estudos de Doutorado na Indiana University, sob orientação de William Estes, obtendo seu título em Teorias Matemáticas da Aprendizagem. Movido pela curiosidade em melhor compreender o regime soviético em plena Guerra Fria, pelo interesse por Pavlov, dada sua formação em Psicologia da Aprendizagem, e pela promessa da Psicologia russa em compatibilizar behaviorismo e estudos da linguagem, aprendeu russo e foi aceito em um pós-doutorado em Moscou, sob a supervisão de Alexandre Luria. Michael Cole não é um intelectual enclausurado em seu contexto local ou mesmo nacional: substantiva parte de seus trabalhos foi desenvolvida em outros países, suas postulações teóricas referemse, em grande medida, à questão das diferenças culturais no funcionamento psicológico e o intercâmbio internacional tem sido um dos principais eixos de seu trabalho.

Em 2004, Lucia Willadino Braga, neurocientista e diretora-presidente da Rede Sarah de Hospitais de Reabilitação, firmou um convênio entre a Rede Sarah e a Universidade da Califórnia, e o programa Quinta Dimensão passou a ser estudado para ser desenvolvido com jovens com lesão cerebral. 
outros sobre as características de uma figura inventiva que vivia na internet; o que pensavam sobre um game ou uma animação que estava em evidência no cinema; entre outros múltiplos temas de interesse comum entre os membros do grupo (COLE, 2006).

Professores universitários engajaram-se nessa atividade com o objetivo de proporcionar aos alunos uma experiência prática relacionada ao seu curso na graduação e de desenvolver pesquisas em programas extraescolares bem-sucedidos. Durante estes encontros o bem-estar das crianças estava nas mãos dos alunos de graduação cuja motivação era a aplicação prática do conhecimento teórico adquirido na academia. O importante era que as crianças e os alunos universitários se divertissem com a atividade (COLE, 2006).

Este projeto provou seu sucesso no alcance de seus objetivos básicos - promover um modelo de atividade extraescolar viável e que favoreça o avanço das aquisições acadêmicas, particularmente as habilidades de letramento para a criança, enquanto fornece ao aluno de graduação experiências práticas para complementar seus estudos teóricos. Essa experiência cresceu, consolidou-se e tem sido implantada por centros universitários em uma variedade de comunidades, não apenas nos Estados Unidos, mas também em outros países. A estratégia de implementação, avaliação e sustentabilidade desse projeto contém referenciais importantes para educadores, pesquisadores e para o desenvolvimento de políticas educacionais mais amplas. É possível que essa experiência possa ser útil a todos que se preocupam com a educação e o bem-estar do adolescente e no modo como eles enfrentam os desafios de uma economia recém-globalizada.

Na concepção deste projeto, foram desenvolvidas hipóteses acerca da motivação para aprendizagem com o uso das tecnologias da informação. Além disso, o uso das tecnologias na colaboração entre universidade e comunidade poderia contribuir para favorecer a educação superior. 
O cenário descrito acima foi impulsionado por questões sociais. Havia, no início da concepção desse projeto, na década de 1980, uma atenção voltada para a ausência de supervisão e apoio de crianças que ficavam sozinhas em casa ou sob supervisão de um irmão com menos de 13 anos. Ocasião em que os objetivos e o estudo dos programas extraescolares estavam em questão e evidência nos Estados Unidos. Todo este contexto motivou o desenvolvimento do sistema educacional 5D, um programa institucional extraescolar, mas com uma nova perspectiva educacional.

Em síntese, o projeto 5D envolve professores universitários, alunos de graduação, crianças e adolescentes da comunidade inseridos na rede de ensino em um processo educacional colaborativo. Um resumo dos objetivos básicos do sistema 5D apresenta uma primeira sistematização do programa original:

1. Atender a necessidade de favorecer aquisições educacionais, oferecendo um ambiente rico para a criança e o adolescente nas horas que permanecerem fora do colégio, com base em teorias apropriadas à idade-atividade.

2. Usar as tecnologias computacionais para atrair o interesse de meninas e de minorias para o programa, de modo a combater a sub-representação desses grupos em posições de autoridade na sociedade em geral e nas profissões em particular.

3. Criar uma estrutura de interação que se retroalimente, tire proveito da diversidade e que reúna crianças, adolescentes e adultos de várias idades e de diversos grupos sociais.

4. Criar um programa educacional sustentável. 


\subsection{Fundamentos teóricos do projeto 5D: Teoria Histórico-Cultural da Atividade}

O programa 5D fundamenta-se em conceitos da Psicologia histórico-cultural, os quais, a partir dos trabalhos de Lev Semenovich Vygotsky(VIGOTSKI, 1994a, 1994b), inspiraram novas formas de pensar o papel da cultura e do desenvolvimento. Esses conceitos são seminais no desenho do programa, pois compartilham ideias-chave que podem ter características diferentes de acordo com as necessidades locais, população e ambiente onde for aplicado.

A teoria histórico-cultural da atividade representa um grupo de teorias que enfatizam a mediação cultural do comportamento enquanto movimento central na constituição da mente humana. Ela está fundamentada na tradição da Psicologia russa, movimento iniciado por Lev Vygotskye seus colegas Alexander Luria e Alexei Leont'ev (ENGESTRÖM, 1987). Enfatiza o papel da cultura e da sociedade na organização dos ajustes proximais do desenvolvimento, onde a mudança individual é estudada. Assim como Jean Piaget e Henry Wallon, Lev Vygotskypreocupa-se e estuda a gênese do pensamento, suas origens e desenvolvimento (OLIVEIRA, 1999).

A teoria da atividade destaca o processo social do desenvolvimento humano, a importância da mediação semiótica nesse processo e a concepção da constituição das funções mentais que ocorrem de forma integrada nos planos filogenético, históricocultural, ontogenético e microgenético. Segundo Vigotski, uma explicação adequada do funcionamento mental humano só poderia ser alcançada através da compreensão de como esses vários domínios genéticos operam dentro de um sistema integrado (WERTSCH; TULVISTE, 1992).

O estudo da singularidade humana diz respeito à filogenia, a história 
evolucionária de uma espécie. Toda espécie tem uma história própria que irá definir os limites e as possibilidades do seu funcionamento. O nosso modo de funcionamento psicológico está relacionado com as características da espécie humana. Nesse plano, teríamos que olhar para trás da história da nossa espécie, a fim de compreender como os processos que são tipicamente humanos se originaram da família taxonômica dos grandes primatas Hominídeos, anteriores ao Homo sapiens, até os dias atuais (OLIVEIRA, 1999). O Homo sapiens desenvolveu-se em um ambiente singular moldado por inúmeras gerações anteriores que lutava pela sobrevivência (COLE, 1998). Esse ambiente foi (e ainda é) constituído por artefatos, pelo conhecimento sobre como construir e usar tais artefatos, por crenças, valores (ideias sobre o que vale a pena) e tudo mais que guia nossas interações com o mundo, com as outras pessoas, com as outras gerações. Os antropólogos denominam de cultura esse acúmulo de artefatos, conhecimentos, crenças e valores (COLE M; COLE S, 2004).

O plano sociogênico está relacionado ao contexto histórico e cultural, que, de certa forma, é fonte do funcionamento psicológico humano. É a parte do ambiente construída pelo homem e o padrão de vida que adquirimos no convívio social (COLE, 1998). Cada cultura organiza o desenvolvimento de uma maneira, o que significa que as fases desse processo são lidas pelas diferentes culturas de forma diversa (OLIVEIRA, 1999). Em síntese, o domínio sociocultural diz respeito à mediação e aos diferentes tipos de ferramentas de mediação adotadas e valorizadas pela sociedade onde crescemos e nos desenvolvemos.

A ontogenia corresponde ao desenvolvimento do indivíduo durante seu tempo de vida, isto é, o indivíduo da espécie e sua passagem pela vida (OLIVEIRA, 1999). Os padrões qualitativamente novos de comportamento que emergem durante $o$ desenvolvimento são chamados de estágios de desenvolvimento. O que um indivíduo 
faz, ou não, depende (inclusive) da etapa do seu desenvolvimento. Por exemplo, existe uma sequência de etapas do desenvolvimento motor relacionadas à maturação cefalocaudal Primeiro a criança adquire o equilíbrio cervical, depois de tronco, até chegar a andar. Essa sequência de eventos tem relação com a filogenia, certamente, e a ontogênese não é pura maturação, porque há uma interpretação cultural dessas etapas, como citamos anteriormente. O domínio ontogenético estuda a apropriação das ferramentas de mediação e como elas são integradas na atividade cognitiva durante os processos de desenvolvimento de um indivíduo.

A inter-relação entre esses planos é fundamental para que possamos compreender como esses domínios se organizam no curso do desenvolvimento. Não há uma sequência linear entre eles, só poderíamos entender a ontogenia como um nível superior à filogenia ou à história cultural, na medida em que a ontogenia sempre se constituiu como um dos mais recentes planos do desenvolvimento (COLE, 1998). A concepção de ampliação de limites nos conduz a esse continuum no desenvolvimento humano. A cultura retroage sobre a filogênese, no sentido de transformar aquele limite que originalmente seria uma restrição, expandindo-o através dos artefatos culturais (OLIVEIRA, 1999).

O quarto plano postulado por Vigotski, chamado microgênese, está relacionado ao processo de aprendizagem de uma dada habilidade, com o desdobramento de um ato psicológico único, próprio de cada sujeito (WERTSCH; TULVISTE, 1992). Na sua essência, a microgênese foca no pensamento momento a momento; essa noção pode ser definida como o ato da cognição. Todo ato psicológico tem a sua história, por exemplo, a história de como alguém aprende a ler, escrever, desenhar, usar um equipamento eletrônico. Como ocorre a passagem entre o não saber e o saber. Esse percurso é 
absolutamente individual e singular, nunca será idêntico em dois sujeitos, é na experiência de cada um que a individualidade se constrói e essa singularidade é datada historicamente (OLIVEIRA, 1999).

\subsection{A origem social do pensamento}

A teoria de Vygotskyenfatiza o desenvolvimento das funções mentais superiores, sociais em sua origem, culturalmente mediadas e envolvidas no controle voluntário e consciente da realização de uma ação (WERTSCH; TULVISTE, 1992). As funções mentais superiores são processos tipicamente humanos como memória, atenção, planejamento, ações intencionais, elaboração conceitual, uso da linguagem e representação simbólica das ações. Essas atividades são de natureza superior porque se diferenciam de mecanismos mais elementares como ações reflexas, reações automatizadas ou processos de associações simples entre eventos. A interação social humana, mediada culturalmente, forma o núcleo da teoria histórico-cultural sobre como essas funções superiores se desenvolvem. A ênfase na origem social do pensamento está fortemente ligada à centralidade da cultura como um meio específico da vida humana (WERTSCH; TULVISTE, 1992).

No seu sentido mais geral, o termo "cultura" foi usado para se referir a um conjunto de padrões de comportamentos humanos, socialmente herdados, e a um sistema de artefatos que serve como recurso para a vida atual de um grupo social, originalmente pensados por habitantes de um país ou de uma região (D’ANDRADE, 1981). Na tentativa de especificar com mais cuidado a noção de cultura como herança social, os antropólogos tendem a interpretá-la de forma polarizada, como algo externo, material, ou interno, como conhecimentos e crenças. A teoria da atividade, por sua vez, 
transcende essa dicotomia concebendo a cultura tanto em sua dimensão material quanto em sua dimensão ideal.

Por um lado, os artefatos possuem aspectos ideais porque incorporam, ao mesmo tempo, propósitos humanos anteriores, pregressos, além das formas de interação que eles mediam no presente. Por outro lado, os artefatos são instrumentos que se materializam na morfologia de uma palavra falada ou escrita, na gestualidade ou em um objeto sólido, como um lápis. Como consequência da natureza dupla ideal-material do sistema de artefatos, o ser humano vive em mundo simultaneamente natural e artificial (COLE, 1998).

Esse ponto de vista da cultura motiva de maneira especial a primazia dada ao contexto social e interindividual do desenvolvimento. Por exemplo, se pensarmos em uma criança, serão os adultos e as crianças mais velhas que já tenham se apropriado do patrimônio cultural do grupo que serão capazes de organizar o ambiente, de modo que ela possa adquirir e eventualmente transcender sua herança cultural.

Artefatos, na forma de instrumentos e signos, funcionam como uma ferramenta psicológica para regular o processo do comportamento, o que por sua vez é a base para o desenvolvimento das funções mentais superiores (NARDI, 1996).Vygotskyenfatiza que as formas do comportamento individual mediadas pela linguagem emergem em comportamentos colaborativos, mediados por artefatos, entre duas ou mais pessoas. É através da participação em atividades sociais mediadas que os indivíduos são expostos pela primeira vez a artefatos como meios para "interferir" no comportamento dos outros membros do grupo social. Só mais tarde o sujeito virá a utilizar esse sistema mediacional para transformar internamente seus próprios comportamentos. É neste processo de apropriação e internalização que as funções mentais mediadas, voluntárias e historicamente contextualizadas se desenvolvem (VIGOTSKI, 1994a). Com base nessas 
premissas, Vygotskydesenvolve o conceito da origem social do funcionamento psicológico individual, ou seja, postula que toda função no desenvolvimento cultural da criança aparece duas vezes: a primeira no nível social, entre sujeitos, e depois, no nível individual, intrapsicológico, incorporados e transformados pela criança. Lev Vygotskydenominou essa ideia de lei genética do desenvolvimento cultural (VIGOTSKI, 1994a).

\subsection{Zona de desenvolvimento proximal: elemento central no sistema educacional 5D}

Um dos elementos centrais na organização da 5D é a participação de diferentes gerações: crianças, alunos universitários e professores. A 5D é organizada para criar uma versão institucionalizada do conceito de zona de desenvolvimento proximal (ZDP), desenvolvida por Vygotsky(COLE, 2006).

Como observado anteriormente, na apresentação da lei genética do desenvolvimento cultural, o desenvolvimento individual das funções mentais superiores (ou seja, a internalização e apropriação dos instrumentos de mediação e seus usos) ocorre por meio da interação social. Vygotskypropôs que a internalização e a apropriação do processo social aconteçam por meio da participação da criança com adultos ou com companheiros, em atividades que vão um pouco além de sua competência. É a partir dessa perspectiva que formula a noção de zona de desenvolvimento proximal (ZDP), a qual define da seguinte maneira:

"zona de desenvolvimento proximal é a distância entre o nível de desenvolvimento real, que se costuma determinar por meio da solução 
independente de problemas e o nível de desenvolvimento potencial determinado através da solução de problemas sob a orientação de um adulto ou em colaboração com companheiros mais capazes" (VIGOTSKI, 1994a; p.112)

O nível de desenvolvimento real caracteriza o desenvolvimento de forma retrospectiva, é uma etapa já superada e ultrapassada pela criança. É um ciclo já completado do desenvolvimento. No entanto, para compreendermos adequadamente o desenvolvimento, devemos considerar não só o que a criança já é capaz de fazer sozinha, mas também a sua capacidade de desempenhar tarefas de adultos ou companheiro mais capaz, algo que Vygotsky denominou nível de desenvolvimento potencial.

A ZDP seria, então, o caminho que o indivíduo vai percorrer para desenvolver funções que estão em processo de amadurecimento e que se tornarão funções consolidadas estabelecidas no seu nível de desenvolvimento real. A ZDP é, pois, um domínio psicológico em constante transformação: aquilo que uma criança é capaz de fazer com ajuda de alguém hoje, ela conseguirá fazer sozinha amanhã (OLIVEIRA, 1999).

O conceito de ZDP reflete a preocupação de Vygotskycom a compreensão da dinâmica entre aprendizagem e desenvolvimento, e, mais especificamente, como a aprendizagem conduz o desenvolvimento. O desenvolvimento na ZDP é caracterizado por mudanças qualitativas nas relações estruturais entre as funções psicológicas. Os indivíduos podem adquirir conhecimentos ou habilidades (aprendizagem), por meio da resolução colaborativa de problemas; a aprendizagem também pode ser vista como uma mudança qualitativa na forma como o indivíduo passa a usar essas habilidades, compartilhando conhecimento com seus pares, ou na mudança qualitativa na forma 
como o indivíduo se relaciona com o ambiente, com independência e autonomia para realizar uma tarefa de forma independente. Nos voltarmos para as capacidades futuras seria, então, o caminho para uma intervenção educacional. Fornecer apoio, demonstração, assistência e pistas são fundamentais para uma prática pedagógica eficiente.

Desde que foi introduzido no Ocidente, o conceito de ZDP tem sido interpretado de várias maneiras. Uma tendência tem sido interpretar a ZDP como uma zona de mudança individual, mudança esta conduzida por novas aquisições de habilidades específicas (GRIFFIN; COLE, 1984). No entanto, a noção de internalização desenvolvida por Vygotskyreferiu-se à aquisição e à transformação do modo como as crianças interagem com os outros em ambientes específicos para resolução de problemas. Nesse sentido, a ZDP deve ser pensada como uma característica não apenas da criança ou do ensino, mas também da criança envolvida em uma atividade colaborativa dentro de uma série de ambientes sociais organizados de diferentes formas.

A "metáfora do andaime" foi uma noção muito usada pelos pesquisadores interessados nas formas como os arranjos ambientais ajudam na aquisição de etapas seguintes do desenvolvimento e parece ter uma forte semelhança com o conceito ZDP. A noção básica é de que a intervenção ou tutoria do adulto deva ser inversamente proporcional ao nível de competência da criança em uma dada tarefa. Assim, por exemplo, quanto maior a dificuldade que a criança tenha em alcançar um objetivo, mais diretiva a intervenção materna deve ser. Muitos autores usam a noção da metáfora do andaime como um sinônimo da ideia de ZDP (GRIFFIN; COLE, 1984). Para alguns propósitos, de fato pode ser. Por exemplo, quando a tarefa for construir uma torre de blocos, a noção do andaime, neste caso, vem facilmente à cabeça como uma metáfora, ou quando dispomos de uma informação na memória que ajude a criança a continuar o 
seu raciocínio. Mas esta metáfora se torna mais problemática quando o foco não está na execução de uma tarefa específica, mas nas mudanças da criança. Uma noção fundamental acerca da ZDP é que a descoberta de novos objetivos é central para o processo de desenvolvimento (VIGOTSKI, 1994a). Se reduzimos o apoio ao tamanho da dificuldade, o desenvolvimento passa a ser limitado pela sabedoria do adulto, e isso mudaria totalmente o sentido proposto pela psicologia histórico cultural acerca do conceito de ZDP (LECUSAY; ROSSEN; COLE, 2008). Não existem etapas previsíveis ou comuns na ZDP, nem medidas estandardizadas para mensurá-las e, certamente, o adulto tem uma função mais ambígua na relação com a criança (GRIFFIN; COLE, 1984). A noção de ZDP inclui, portanto, modelos voltados para o futuro e modelos voltados para o passado em uma atividade que se desenvolve nestas contradições.

Essa interpretação desloca o foco do indivíduo para o sistema social do ensino e outros arranjos sociais educacionais, os quais emergem de atividades colaborativas e recíprocas entre todos os envolvidos no processo educacional. O foco, portanto, deve estar no uso colaborativo dos meios mediacionais para obter e criar significados, e, ainda, comunicar-se. As diferenças de experiências entre os sujeitos envolvidos em um sistema de aprendizagem deveriam, então, através de conversa exploratória entre o grupo e outras mediações sociais, ajudar as crianças a apropriar-se ou tomar o controle de sua própria aprendizagem. Assim, a ZDP não precisa ser criada individualmente, mas de maneira coletiva, na medida em que os sujeitos interagem em um sistema social diversificado com zonas de apoio mútuo e continuamente mostrando o que sabem, o que estão aprendendo, como estão usando o que sabem e como estão lidando com situações instrucionais novas e mais avançadas.

Um dos grandes esforços para organizar as atividades da quinta dimensão pode ser visto em termos da concepção de um sistema social que crie zonas de 
desenvolvimento proximal para o grupo e para o indivíduo. A Quinta Dimensão pretende ser compreendida com uma ZDP em larga escala, como princípio básico para a organização da atividade (COLE, 2006). Embora mantenha o princípio de um grupo de pessoas de diferentes níveis de desenvolvimento, a estrutura de participação na 5D é projetada para minimizar as diferenças de poder entre os participantes, com foco particular sobre a dinâmica de interação entre alunos de graduação, crianças e adolescentes com quem trabalham. Essas condições incentivam uma ambiguidade saudável sobre quem é mais capaz que o outro na ZDP. Por exemplo, alunos de graduação que participam do projeto 5D pela primeira vez muitas vezes são confrontados com jovens que podem ser participantes de longa data no programa. A familiaridade com a cultura da Quinta Dimensão posiciona as crianças e os adolescentes como os companheiros mais experientes do que os alunos de graduação, que precisam de apoio para ser introduzidos no programa. Essa circunstância cria, por sua vez, uma zona potencial para comunicação mais deliberada entre os estudantes, as crianças e os adolescentes, o que, por sua vez, abre diferentes oportunidades para interação colaborativa entre o grupo.

Ao organizar a interação social na Quinta Dimensão, de maneira a permitir a colaboração entre sujeitos com diferentes níveis de conhecimento, a tentativa foi criar para os participantes do programa original, em particular os alunos de graduação, oportunidades para conceituar de novas maneiras a aprendizagem e a sua interrelação com o desenvolvimento. Ao invés de pensar a aprendizagem em termos do que o adulto pode oferecer à criança, foi criada a possibilidade para o aluno de graduação pensar na educação enquanto processo que emerge da compreensão mútua (COLE, 2006).

Zonas de desenvolvimento não podem existir sem a via da compreensão mútua entre os participantes do sistema educacional. É através da consciência de como o outro 
compreende a situação de interação que os processos comunicativos se tornam viáveis. Em síntese, a teoria da atividade que embasa o sistema educacional 5D expande (radicalmente) a nossa noção do que é uma unidade de análise da aprendizagem. Então, aprender não está limitado ao que acontece internamente em um indivíduo, mas sim relacionado a algo que é distribuído, compartilhado entre indivíduos, pares sociais, artefatos materiais e seus recursos semióticos, todos imersos em uma ampla ação social coletiva. Portanto, atividades não são unidades isoladas, mas sim nós em uma rede hierárquica que se entrelaçam influenciados por outras atividades e mudanças no ambiente. A influência externa muda alguns elementos da atividade, causando desequilíbrios nessa rede. A teoria da atividade usa o termo "contradição" para indicar esse desajuste dentro dos seus elementos componentes, entre elementos, entre diferentes atividades ou entre diferentes fases de uma atividade específica. Contradições manifestam-se, tais como problemas, rupturas, desarranjos, confrontos. A teoria da atividade interpreta a contradição como fonte de desenvolvimento (NARDI, 1996).

\subsection{O protótipo do sistema educacional 5D}

O protótipo desse sistema foi concebido como um quadro para a compreensão dessa intervenção educacional e como valor de referência para experiências do programa em outros contextos. Na prática, foi pensado um desenho de atividade, no qual todos os envolvidos quisessem e gostassem de participar.

Esse protótipo mescla o interesse dos adolescentes nos games com o interesse educacional teórico dos games; foi pensado de forma a propiciar várias oportunidades de comunicação oral e escrita e estratégias para resolução de problema. As ferramentas digitais foram incluídas na atividade, pensando em fomentar as chances de comunicação 
entre o grupo. $\mathrm{Na}$ medida do possível, seria importante reconhecer o esforço do adolescente pelo seu engajamento em um jogo em particular, ou pelo seu esforço intrínseco na atividade, de forma que a sua maior motivação fosse retornar e crescer na própria atividade. Essa estrutura permanece relativamente constante entre as diferentes gerações do programa (COLE, 2006).

A ferramenta central do sistema são os computadores. O computador serve como ponto de partida para todo um universo de atividades. De acordo com as regras da 5D, os adolescentes fazem progresso no programa através de um labirinto. O labirinto é um espaço simbólico que pode ser representado por um cartaz, como labirinto físico ou, ainda, eletrônico, onde estão indexados todos os jogos e as outras ferramentas disponíveis no sistema 5D. Conforme avançam nesse espaço virtual, vão ganhando mais e mais autonomia e propriedade no sistema como um todo.

A presença de um labirinto virtual com múltiplas salas cumpre muitas funçõeschave no programa: fornece uma representação total do conjunto de jogos e desafios em que o adolescente pode engajar-se; é uma ferramenta de distribuição de atividades de uma maneira flexível, mesmo que um jogo esteja ocupado, existem alternativas negociáveis para substituí-lo; isso mostra ao adolescente que ele pode fazer escolhas entre uma série de alternativas, quaisquer que sejam seus objetivos específicos.

Dentro de cada sala do labirinto estão indexados vários desafios a cumprir. $\mathrm{O}$ desafio foi a ferramenta criada para regular a relação entre o jogo e a educação, regular o nível de dificuldade no engajamento em determinado jogo e para garantir a possibilidade de divisão de trabalho. Além disso, ele torna possível à equipe que trabalha nessa elaboração garantir que sejam incorporadas ao programa habilidades educacionais, tais como leitura, escrita e pensamento reflexivo. Para cumprir seus desafios, a criança compartilha suas dúvidas com os alunos de graduação, na busca de 
soluções conjuntas para os problemas criados por esse sistema de atividades.

Três outras características desse parque de atividades educacionais requerem menção. A primeira é a figura mítica; e a segunda, uma constituição. Historicamente, foi a figura mítica quem deu a 5D às crianças, ou seja, um lugar para jogar e aprender. Essa figura nunca aparece fisicamente, mas desempenha muitas funções remotamente. Ela reordena as relações de poder entre os participantes e ajuda a resolver conflitos, mediando disputas e negociando regras. Nunca aparece pessoalmente. Não é nem do sexo feminino, nem do masculino. Não mora em um lugar específico. É híbrido. Comunica-se sempre pela linguagem escrita, por meio de e-mails o que cria muitas oportunidades para que os adolescentes se engajem em situações de comunicação, leitura e escrita de forma espontânea e contextual. Essa figura tem um papel importante na dinâmica do grupo. Na presença de um conflito no grupo, não há confronto na medida em que essa figura irá intervir na situação e ajudar a reordenar as relações, baseando-se, inclusive, na constituição, que foi escrita por essa entidade, com a colaboração de todos, e está disponível on-line para consulta e para ajudar a comunidade a alcançar seus objetivos. Novas regras, que irão compor a constituição ou a exclusão de outras, podem ser debatidas e sugeridas pelo grupo à figura mítica.

E, por último, o livro de dicas um recurso onde os adolescentes e os alunos de graduação descrevem estratégias e descobertas acerca dos jogos. Essa ferramenta encoraja a comunidade 5D a acumular informações e a construir a sua própria história no tempo, além disso, quando as coisas ficam difíceis, por exemplo, caso um adolescente não consiga passar de uma fase de um jogo, ele tem um recurso a mais para procurar ajuda. É possível que um companheiro de 5D já tenha enfrentado situação semelhante e registrado como resolveu o problema. Cada projeto $5 \mathrm{D}$ desenvolve e incorpora diferentes artefatos e meios mediacionais, a depender do contexto em que será 
inserido.

Em síntese, a 5D foi concebida por uma equipe do LCHC da Universidade da Califórnia cujo objetivo foi desenvolver um programa educacional que apoiasse ao mesmo tempo a formação prática de alunos de graduação e a aprendizagem escolar de crianças e adolescentes que enfrentavam uma situação social de isolamento. $\mathrm{O}$ projeto fundamenta-se na psicologia histórico-cultural e tem por princípios:

1. Promover a aprendizagem colaborativa entre diferentes gerações (estudantes universitários, crianças e adolescentes);

2. Criar situações de interação que favoreçam o desenvolvimento de habilidades sociais como base para novas aprendizagens;

3. Usar as tecnologias, games e jogos diversos como elementos de motivação para aprendizagem escolar;

4. Propiciar oportunidades contextualizadas de comunicação oral e escrita;

5. Desenvolver estratégias compartilhadas para a resolução de problemas. 


\section{A QUINTA DIMENSÃO DA REDE SARAH}

Para implantar a 5D na Rede Sarah, não havia outra maneira senão por meio de um processo gradual de adaptação do sistema educacional à população com lesão cerebral. Várias características do projeto educacional original favoreceram esse processo e sabíamos que era um programa promissor para adolescentes, tanto por seus fundamentos teóricos quanto por sua consonância com os projetos de reabilitação da Rede Sarah. Estava demonstrado que o modelo poderia ser efetivamente usado em uma ampla variedade de ambientes culturais fora dos Estados Unidos, pois já havia sido adotado com sucesso na Rússia, na Finlândia, na Dinamarca e no México, com diferentes populações (COLE, 2006).

Nas suas origens na Califórnia, o programa funcionava em instituições comunitárias, que por natureza são inclusivas. Isso levou à participação de algumas crianças com necessidades especiais, com quadro muito diferente umas das outras: algumas estavam em uso de medicamento para melhorar os sintomas da desordem de atenção e hiperatividade, outras tinham retardo mental e uma delas, diagnóstico de Síndrome de Asperger (COLE, 2006). Evidências informais apontavam que crianças com necessidades especiais poderiam se beneficiar do programa, mas nada ainda sistematizado. Sabíamos que nossa experiência iria diferir dos outros projetos pela natureza da população com a qual estávamos trabalhando. Tratava-se de adolescentes com lesão cerebral, a maioria com problemas de ajuste comportamental.

A primeira questão que procuramos entender foi se o modelo básico da Quinta Dimensão poderia ser adaptado para uso em um hospital de reabilitação. Iniciamos o programa plenamente conscientes de que a 5D poderia variar significativamente em detalhes de implementação, mas não sabíamos ainda em quais. A nossa suposição era de 
que estaríamos criando, de fato, um novo projeto. A implantação e adaptação do projeto 5D na Rede Sarah começou em 2006, especificamente na unidade de Brasília. Esse protótipo foi extremamente importante, pois serviu de base para a consolidação do programa na rede.

As primeiras adaptações realizadas seguiram quatro eixos principais:

. Adaptações nos artefatos mediadores da atividade.

. Ajustes no protótipo do sistema educacional.

. Participação dos pais.

. Desenvolvimento de um projeto de estágio para os alunos de graduação.

\subsection{Adaptações nos artefatos da atividade}

Para iniciarmos o programa, convidamos para participar do projeto piloto um grupo de crianças e pré-adolescentes entre 8 e 12 anos de idade, com lesão cerebral. Esse grupo apresentava formação bastante heterogênea, não só no que se refere ao desenvolvimento cognitivo e motor, mas também em relação às experiências prévias com tecnologia. A maioria deles tinha pouco ou nenhum acesso a jogos de computador e conhecimento limitado sobre o uso de e-mail, busca na internet e edição de texto. Vários adolescentes já haviam tido contado com algumas dessas ferramentas na escola. Cinco jovens possuíam computador em casa, mas raramente o usavam. Apenas duas crianças do grupo tinham videogame em casa. Todas inseridas na rede de ensino, o que sempre foi uma prerrogativa não negociável para participar do projeto; e todas com algum nível de defasagem idade-série. Duas crianças tinham graves alterações motoras e excelente capacidade cognitiva. Incorporar novos artefatos à atividade possibilitou que diferentes rotas de interação sujeito-mediação-objeto, que operam no sistema, fossem 
intensificadas.

Para crianças com limitações motoras e fala pouco inteligível, foram implementadas formas alternativas de comunicação para expandir seus meios de expressão e intensificação dos níveis de troca e interação entre o grupo. Alguns desses artefatos foram incorporados ao sistema como: acionadores para o controle de sistema eletrônico; pranchas de comunicação com símbolos pictográficos para apoio ampliação do vocabulário expressivo, acionamento de voz, o uso do teclado virtual com sistema de varredura e ajuste de tamanho da fonte.

\subsection{Ajustes no sistema educacional}

Conforme descrito no protótipo do projeto original, em princípio, toda vez que um adolescente acessa um jogo na 5D o seu engajamento é mediado por um cartão de tarefa que especifica o que ela tem que realizar para obter créditos como performance iniciante, média ou avançada da tarefa em questão. Esse mesmo desempenho é um critério para "promover" o adolescente à função de assistente, um papel atribuído pela figura mítica, ou seja, à medida que aprimora seu desempenho no sistema educacional, altera-se seu status social no grupo.

No entanto, as especificidades do desenvolvimento de crianças com lesão cerebral nos fizeram questionar e rever essa estratégia de engajamento e desnivelamento do grupo. Uma vez que o potencial, o limite e o grau de desempenho das crianças com lesão cerebral são muito variáveis (BRAGA; CAMPOS DA PAZ JUNIOR, 2008), algumas crianças com lesão cerebral poderiam ter bastante dificuldade em atingir níveis 
específicos de desempenho em algumas tarefas. Um adolescente com alterações neurocognitivas pode não ser capaz de alcançar diferentes fases de um jogo de videogame, cuja complexidade aumenta gradativamente. Contudo, isso não quer dizer que ele não possa se desenvolver em outros domínios do comportamento ou cumprir desafios que se tornassem fatores de desnivelamento do grupo. Assim, desenvolvemos o que chamamos de projetos individuais em um sistema coletivo de atividades. Esses projetos eram calibrados pela ZDP e relacionados ao papel social de cada um na microcultura. Por exemplo, um garoto de 13 anos que nasceu com uma esquizencefalia, uma rara malformação congênita cerebral, tinha uma atração especial por quadrinhos e adorava mangás. Ao mesmo tempo em que navegava no labirinto como todos os colegas, essa sua motivação e talento tornou-se um desfio pessoal reconhecido pelo grupo. E ainda poderíamos apontar vários outros exemplos, tais como: um garoto que gostava de cinema e imagens; outro, de som; uma menina, de fantasias. A proposta era desnivelar o grupo pela habilidade.

A Figura 1 fornece uma visão geral da 5D na Rede Sarah. O artefato central que está no coração da 5D é um labirinto com 17 salas, cada uma contendo três atividades e cada atividade relacionada a uma habilidade. Mantivemos uma área de atividades não computacional, com jogos de tabuleiro, pintura, quadrinhos, além de um parque eletrônico contando inicialmente com um Playstation ${ }^{\circledR}$. Todas as atividades estavam indexadas ao labirinto. O contato com a figura mítica poderia ser feito através de bilhetes deixados em um mural, ou mesmo por e-mail, e um livro de dicas garantia o registro das descobertas acerca dos jogos. 


\section{D - Rede SARAH}

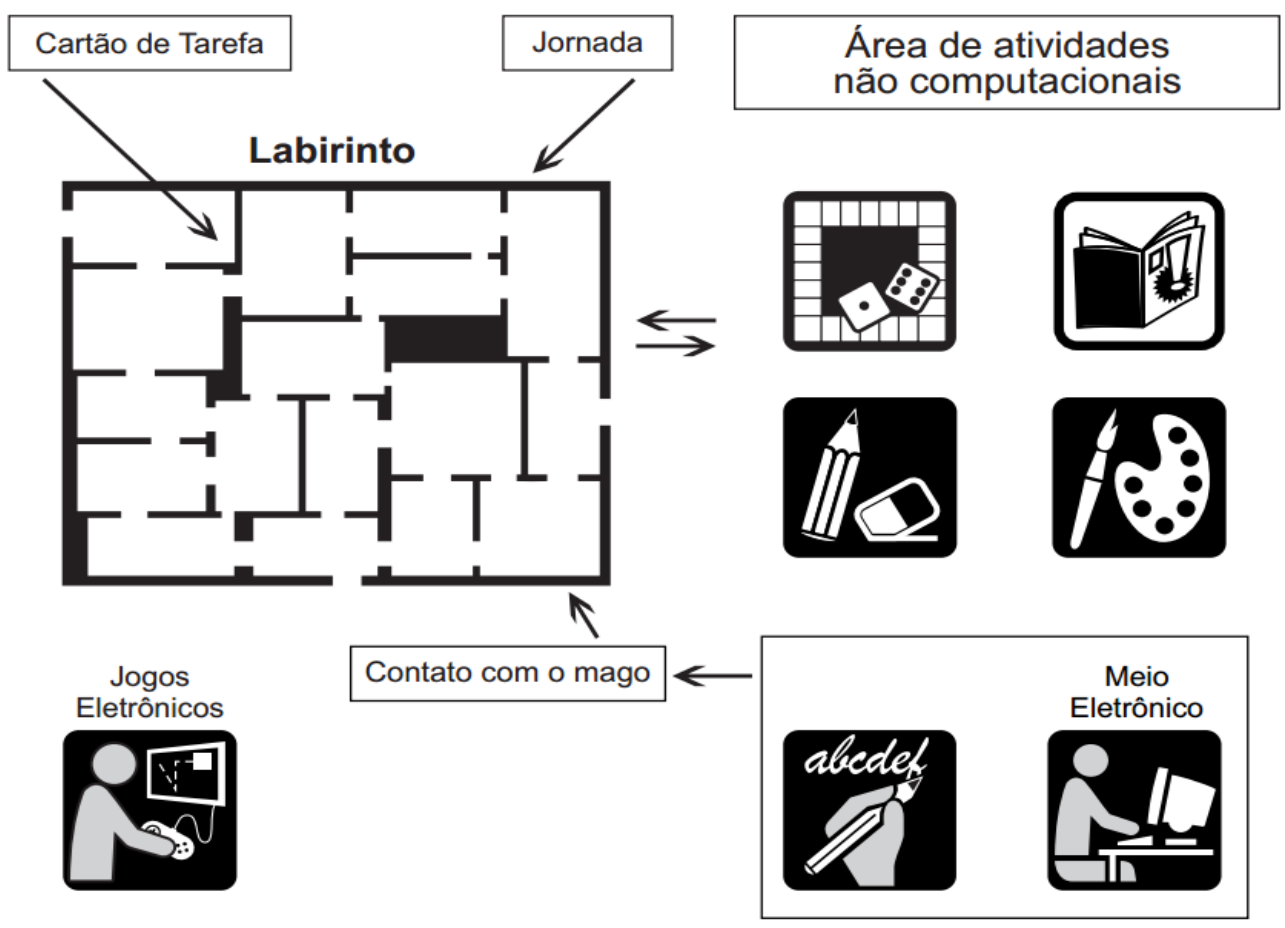

Figura 1 - Visão Geral Esquemática do Labirinto e outros artefatos 5D

\subsection{Participação dos pais}

Toda vez que uma criança ou um adolescente vem ao centro de reabilitação, algum membro da família está presente. $\mathrm{O}$ modelo de participação da família no programa de reabilitação na Rede Sarah vem sendo desenvolvido e aprimorado desde a década de 1980 (BRAGA; CAMPOS DA PAZ JUNIOR, 2008; BRAGA; CAMPOS DA PAZ JUNIOR; YLVISAKER, 2005; BRAGA, 2009). É a família que convive com o adolescente no dia a dia, que tem informações relevantes sobre seu filho, sobre o que enfrenta na vida cotidiana e a sua perspectiva é fundamental para que a equipe técnica trabalhe em um projeto individualizado e significativo de reabilitação. É esperado que o 
seu envolvimento no programa de reabilitação varie ao longo do desenvolvimento, assim como variam as interações entre pais e filhos e os interesses sociais conforme a etapa da vida. Dada a estrutura do projeto 5D, tínhamos que estudar como essa família seria inserida no programa uma vez que ela não participava do projeto original.

Diferentemente do modelo original da Quinta Dimensão, os adolescentes tratados na Rede Sarah não moram nas redondezas do hospital, algumas possuem problemas de locomoção e dependem das famílias para trazê-las ao centro de reabilitação. Sendo assim, a criança sempre está na companhia dos pais. Inicialmente, os pais chegavam às salas do projeto, localizadas na área de reabilitação e especialmente adaptadas para esse fim, interessados em participar das atividades de seus filhos com os estudantes universitários. Essa reação dos pais era esperada, haja vista que eles se acostumaram a mediar as interações e o desenvolvimento de seus filhos. No entanto, os pais logo perceberam que seus filhos estavam estabelecendo relações com os estudantes sem a necessidade de sua presença. Alguns adolescentes chegaram a pedir aos pais que aguardassem fora da sala de atividades.

Para acomodar essa nova situação, foi criado no projeto 5D um espaço específico para os pais: quinzenalmente é realizado um grupo de pais com a participação das famílias dos adolescentes que frequentam o projeto e da equipe de técnica de reabilitação. Não é um grupo terapêutico, mas um grupo de troca de experiências. No começo de cada semestre, juntas, equipe técnica e família fazem um cronograma de temas de interesse sobre desenvolvimento. Esses temas são debatidos ao longo dos encontros, os pais colaboram e elaboram o conteúdo selecionado para discussão, são encorajados a fazer associações sobre o que está sendo discutido, o desenvolvimento do filho e o seu próprio desenvolvimento, utilizando a mesma base 
conceitual usada no sistema educacional com os adolescentes. A cada encontro são repassadas informações sobre as atividades do projeto 5D.

Um primeiro estudo dessa proposta foi realizado, analisando a percepção dos pais acerca dessa experiência. Os pais testemunham a independência e a melhoria nas interações sociais e na autoestima de seus filhos. Uma das mães relatou: "Minha filha estava estagnada, mas vejo quanto cresceu agora. Ela está mais independente e foi até capaz de viajar sozinha nas últimas férias. Ela está confiante o suficiente para fazer novos amigos”. Outra mãe expressou uma importante situação envolvendo autoestima. "[Meu filho] estava jogando basquete com alguns colegas normais. O time dele estava perdendo, então ele chamou um de seus colegas e disse: 'Tome o meu lugar, você pode jogar melhor do que eu. Devo essa mudança de atitude do meu filho a esse programa". A questão da participação dos alunos de graduação também foi enfatizada pelas famílias: "O fato de haver estudantes ajudou meu filho a se tornar mais centrado e focado... eles são próximos em idade" (BRAGA; ROSSI; COLE, 2010).

\subsection{Desenvolvimento de um projeto de estágio para os alunos de graduação}

O programa para alunos de graduação foi organizado em três módulos (I, II e III), cada um com duração de um semestre. Participam do projeto estudantes de graduação em Psicologia e Pedagogia. A proposta era criar um grupamento vertical de estudantes. O estagiário pode ficar até um ano e meio no projeto. O que muda nesse período é a experiência individual de cada um deles, o que faz com que assumam gradual e naturalmente diferentes tarefas. O fluxo de entrada e saída, ao longo da implantação do projeto, garantiu a pluralidade necessária a esse sistema educacional. Os 
alunos são encorajados a interagir com os adolescentes usando conceitos da aprendizagem colaborativa e fornecendo o mínimo de ajuda possível, mas o bastante para que, juntos, façam novas descobertas. Trabalhando em pares ou em pequenos grupos, constroem coletivamente seu conhecimento através da troca constante de informações, de pontos de vista e de questionamentos.

Ao término de cada sessão de atividades, os de alunos de graduação refletem acerca da sua interação com os adolescentes. A equipe de supervisão do estágio acompanha a discussão, fornece dicas práticas, busca o apoio de todo o grupo na análise das situações vivenciadas e sugere leituras técnicas. A grade teórica se forma a partir das necessidades de cada grupo. Há uma base de leituras previstas que é complementada pela necessidade e pelo questionamento de cada grupo de alunos. Além da discussão supervisionada, os alunos elaboram um diário de campo sobre suas interações com o adolescente. Esses diários de campo são dados primários sobre esse sistema cultural. Utilizando a narrativa descritiva, iniciam o diário de campo com observações gerais sobre o cenário das suas interações para aqueles que irão ler as anotações. Em seguida, fazem um zoom nas suas interações com os adolescentes e a equipe de reabilitação naquele dia, descrevem o comportamento dos adolescentes, evitando interpretá-lo. Fazem um resumo das atividades realizadas e artefatos utilizados e, para fechar, narram seus pensamentos e opiniões sobre o que aconteceu naquele dia. O que aprenderam sobre si mesmos e sobre os outros. Procuram fazer pequenas análises e relações teóricopráticas.

Cada diário era lido e comentado por diferentes componentes do grupo, equipe técnica de reabilitação e colegas de estágio, promovendo uma rede de comunicação e, também, uma estratégia para acompanharmos o desenvolvimento dos alunos. Os alunos 
tinham a oportunidade de comentar e responder a comentários de seus colegas on-line. O site também ajudou na comunicação em geral, assim como na disseminação da bibliografia, no debate e na discussão a respeito do desempenho das crianças. 


\section{A EXPANSÃO DA 5D: O PROBLEMA DE ESTUDO}

A motivação dos adolescentes com lesão cerebral pelo universo tecnologia do projeto 5D era evidente. Dispúnhamos de muitos artefatos de interesse do grupo, próprios para idade e para aumentar o repertório de interação social, mas tornou-se preponderante a opção pela navegação na internet; pelo uso de jogos eletrônicos e de um espectro amplo de diálogos possíveis in-game e out-game; pelo uso de sites de música associados a compartilhamento; pelo interesse por imagens para expressão. Os participantes estavam interessados, acima de tudo, nas relações com colegas da 5D. Havia muito prazer em conectarem-se uns com os outros através do ambiente dos jogos, dos desafios coletivos. A tensão competitiva digital ocorria, mas era transformada em desafios e em momentos de aprendizagem. Ao invés de esforçar-se, como normalmente faria na escola, em direção ao acerto, na 5D os adolescentes buscavam ajuda no sentido colaborativo impresso na relação entre pares, entre o grupo, com a ajuda da figura mítica e de toda a estrutura social do sistema educacional. Essa forma de participação foi prevista e detalhadamente estudada na implantação do sistema educacional com sujeitos com lesão cerebral, mas havia algo a mais que estava se manifestando nesse grupo: o interesse pela interação social mediada pelo computador.

Todo esse movimento foi gradual e compassado com a expansão do programa. Em agosto de 2007, tínhamos dois grupos em funcionamento em Brasília, um às quartas e sextas-feiras e o outro às terças e quintas-feiras. Os alunos de graduação que participavam de um grupo ou de outro se conheciam, promoviam algum nível de interação entre os grupos compartilhando e-mails, sugestões para mudanças de regra, e 
muito rapidamente essa necessidade cresceu. O mesmo aconteceu com os adolescentes com lesão cerebral que passaram a usar o Livro de Dicas e um mural para deixar recados ou informações sobre os jogos para os colegas. Em 2010, quando abrimos o grupo 5D em São Luís, passamos a usar o sistema de videoconferência para interação e troca de experiência entre os alunos de graduação, como uma forma de integração dos projetos nas diferentes unidades da Rede Sarah e da supervisão educacional do estágio. Contudo, ainda não tínhamos uma forma de integração efetiva entre os participantes dos programas, e o pouco que tínhamos era mais restrito aos estagiários.

A partir de 2010 o impulso de crescimento do programa 5D foi realmente intenso. Por um lado, o modelo educacional era absolutamente consonante com os princípios teóricos e filosóficos do trabalho de reabilitação desenvolvido na Rede Sarah, e, por outro, esse projeto foi extensamente discutido com a equipe de pesquisa em Educação, Tecnologias e Comunicação do laboratório Ábaco, da Faculdade de Educação na Universidade de Brasília, de onde surgiram possíveis alternativas associando tecnologia da educação e reabilitação para a 5D.

A intensidade de todo esse movimento pode ser facilmente evidenciada pelo percurso de implantação e pelo alcance que o programa tomou. Em um período de sete anos, o projeto foi implantado em seis diferentes unidades da Rede Sarah localizada em Brasília, São Luís, Rio de Janeiro, Macapá, Belém e Fortaleza, e foram abertos dez diferentes grupos. Nunca um só grupo retrocedeu, ao contrário, apenas crescemos. Saímos de uma célula experimental, focal e localizada no Centro-Oeste, em Brasília, para, num espaço relativamente curto de tempo, expandirmos o projeto para as regiões Norte, Nordeste e Sudeste do Brasil.

Tínhamos implantado em diferentes unidades de uma rede de hospitais de reabilitação um mesmo programa, com os mesmos princípios e fundamentos, para 
população com características e necessidades semelhantes e a possibilidade de distribuir conhecimento entre o grupo passou a ser um foco de interesse quase natural para estudo. Isso significava expandir o ambiente de aprendizagem.

A expansão é uma forma de aprendizagem que transcende as dimensões lineares, socioespaciais individuais e de ação. Pensar numa abordagem expansiva da aprendizagem é compreendê-la em uma perspectiva temporal mais ampla do que a atividade específica ou a área de ação imediata. Expandir é o resultado de um processo de transição de ações desempenhadas por indivíduos para uma nova atividade coletiva (SANNIO, A; GANIELS, H; GUTÍÉRREZ, 2009).

Portanto, a partir do interesse na comunicação remota manifestado pelos adolescentes com lesão cerebral e estagiários associado ao curso de crescimento do programa com a implantação de novos grupos nas diferentes unidades da rede Sarah, nossa hipótese era de que a inserção de uma rede social digital no sistema educacional 5D poderia expandir e dar novos significados às oportunidades de aprendizagem e obteríamos, assim, parâmetros para concebermos uma rede educacional aplicada à reabilitação, ao mesmo tempo em que responderíamos à motivação dos membros do grupo.

Concluindo, a possibilidade de expansão da 5D significava uma possível alternativa para a transformação qualitativa da atividade. Todas essas reflexões não intencionavam qualquer forma de ruptura, ao contrário, queriam incluir e transcender o objeto de ação da atividade e, assim, navegar em diferentes zonas de desenvolvimento colaborativo. Um site de redes sociais que interligasse todos os programas $5 \mathrm{D}$ nos diferentes estados permitiria, a partir da construção de um perfil de cada usuário, a interação por meio de comentários e a exposição pública dentro do sistema 5D. A ideia de uma rede fechada e experimental estava embasada na vulnerabilidade 
comportamental dos adolescentes após uma lesão cerebral. Além dos adolescentes, os alunos de graduação também seriam atores dessa rede, o mesmo grupo de sujeitos diretamente envolvido no sistema 5D off-line, seriam eles, os adolescentes e os alunos, que formariam e moldariam as estruturas sociais dessa rede, por meio dessa nova perspectiva de interação.

Nesse contexto foram delimitados os objetivos deste estudo.

\subsection{Objetivo geral}

Expandir o sistema educacional 5D por meio da criação de uma rede social concebida para promover o desenvolvimento de habilidades colaborativas em adolescentes com lesão cerebral.

\subsection{Objetivos específicos}

- Implantar uma rede social que atenda às características e ao trabalho de reabilitação com adolescentes com lesão cerebral no contexto do sistema educacional 5D.

- Analisar a avaliação feita pelos usuários da rede social implantada (adolescentes com lesão cerebral e alunos de graduação de Psicologia e Pedagogia) quanto à sua utilização.

- Comparar a avaliação dos usuários da rede: alunos de graduação e adolescentes com lesão cerebral. 


\section{REDE SOCIAL, EDUCAÇÃO E REABILITAÇÃO}

A questão principal que norteou esta revisão bibliográfica foi identificar nas fontes da literatura o estado da arte sobre o uso de redes sociais na reabilitação de adolescentes com lesão cerebral. Essa questão fundamenta-se em uma série de evidências, dados da literatura, acerca da importância de favorecer a comunicação e o comportamento social de adolescentes com lesão cerebral nos programas de reabilitação (DROTAR et al., 2004; RYAN et al., 2013; TURKSTRA; MCDONALD; DEPOMPEI, 2001), na valorização e respeito aos meios de interação social que, hoje, são próprios do interesse dessa fase de vida e na intenção de incorporar sites de redes sociais aos programas de reabilitação dos jovens em acompanhamento na Rede Sarah.

Com esse objetivo, conduzimos uma revisão criteriosa em três grandes bancos de dados acadêmicos que incluem os domínios da saúde, da psicologia e da educação: PubMed; PsycINFO e Eric. Fechamos como público-alvo a população de sujeitos com lesão cerebral. Como estratégia de busca, usamos os seguintes termos: "internet" ou "social networking site" ou "eletronic mail" e "brain injures", sendo que o termo internet engloba "blogging” e "social mídia". Não estabelecemos limites quanto ao tipo, ano ou língua de publicação. No entanto, limites foram colocados à idade dos

participantes do estudo para garantir que as fontes estivessem relacionadas à adolescência e à pré-adolescência, público-alvo do programa 5D. Toda duplicação e sobreposição de publicação foi excluída.

Inicialmente foram identificadas 59 fontes que preencheram os critérios para a inclusão nesta revisão. Todas eram artigos. Depois de uma análise dos títulos e sumário desses 59 artigos, selecionamos 17 fontes que corresponderam aos critérios relevantes para esta revisão. As fontes bibliográficas estão listadas na tabela 1, segundo a ordem de 
data de publicação e primeiro autor palavras-chave, tamanho da amostra, faixa etária, população alvo do estudo e tipo de rede social utilizada na Internet. Essas fontes incluíam dois estudos exploratórios (AHMED et al., 2013a, 2013b); sete ensaios clínicos randomizados (CAREY; WADE; WOLFE, 2008; KARVER et al., 2014; KUROWSKI et al., 2013, 2014; WADE et al., 2010, 2011, 2012); um estudo descritivo/qualitativo (RAGHAVENDRA et al., 2012); cinco estudos antes e depois (RAGHAVENDRA et al., 2013; WADE; MICHAUD; BROWN, 2005; WADE; WOLFE; PESTIAN, 2004; WADE et al., 2008, 2009); uma revisão sistemática da literatura (KILOV et al., 2010); e um estudo transversal multicêntrico (YOUNG et al., 2009). A primeira publicação localizada data de 2004 e as duas últimas, de 2014, quando fechamos este levantamento. Os artigos listados na tabela 1 serão citados ao longo deste capítulo, conforme sua numeração.

\subsection{Termos de busca, convergências e preocupações}

A primeira análise que nos chamou a atenção neste levantamento tem relação com os fatores de busca. Os termos "internet", "social networking site", "eletronic mail", "blogging" e "social mídia" foram todos usados para descrever comunicações síncronas que ocorrem através da internet entre duas ou mais pessoas, o que tornou difícil filtrar os resultados e identificar fontes adequadas para inclusão nesta revisão. Tudo isso gerou, inicialmente, um número de fontes relativamente grande de publicações $(n=59)$. Essas publicações, supostamente, atenderiam aos objetivos deste levantamento. No entanto, apenas $28 \%(\mathrm{n}=17)$ dos artigos tinham relação direta com o tema em questão. Além disso, 88\% dos artigos foram publicados entre 2008 e 2014, 
sendo assim publicações recentes. Estas são evidências de que o uso de sites de redes sociais na reabilitação do adolescente com lesão cerebral é, ainda, um tema novo de estudo, com bibliografia específica escassa e recente.

Tabela 1 - Revisão da literatura: redes sociais e reabilitação

\begin{tabular}{|c|c|c|c|c|c|c|}
\hline \multicolumn{7}{|c|}{$\mathbf{N}^{\mathbf{0}}$} \\
\hline & Data Autor & Palavras chave & Amostra (n) & Faixa etária* & Populaçãa*** & Mídia* \\
\hline 1 & 2014, Karver & $\begin{array}{l}\text { Traumatismo craniano; } \\
\text { adolescentes; telesaúde; } \\
\text { Solução de problemas; } \\
\text { reserva cognitiva }\end{array}$ & 132 & $12-17$ & $\begin{array}{c}\text { Adolescentes } \\
\text { com TCE e } \\
\text { familiares }\end{array}$ & Ss \\
\hline 2 & 2014, Kurowski & $\begin{array}{l}\text { Lesão cerebral; online, } \\
\text { terapia, função executiva, } \\
\text { criança, adolescente }\end{array}$ & 132 & $12-17$ & $\begin{array}{l}\text { Adolescentes } \\
\text { com TCE e } \\
\text { familiares }\end{array}$ & Ss \\
\hline 3 & 2013, Ahmed, a & $\begin{array}{l}\text { Ética, confidencialidade, } \\
\text { privacidade, } \\
\text { confiabilidade }\end{array}$ & $\mathrm{N} / \mathrm{C}$ & Adultos jovens & $\mathrm{N} / \mathrm{C}$ & SRS; Ss \\
\hline 4 & 2013, Ahmed, b & 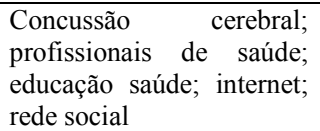 & 8 profissionais & $\mathrm{N} / \mathrm{C}$ & Profissionais & $\mathrm{N} / \mathrm{C}$ \\
\hline 5 & 2013, Kurowski & $\mathrm{N} \backslash \mathrm{C}$ & 132 & 14-17 & $\begin{array}{l}\text { Adolescentes } \\
\text { com TCE e } \\
\text { familiares }\end{array}$ & Ss \\
\hline 6 & 2013, Raghavendra & $\begin{array}{l}\text { Deficiência, Internet, } \\
\text { intervenção, participação } \\
\text { social, juventude }\end{array}$ & 18 & $10-18$ & $\begin{array}{c}\text { Jovens } \\
\text { deficientes } \\
\text { (incluindo } \\
\text { sujeitos com } \\
\text { LCA) e } \\
\text { familiares }\end{array}$ & SRS \\
\hline 7 & 2012, Raghavendra & $\begin{array}{l}\text { Internet, jovens, } \\
\text { deficiência física, padrões } \\
\text { de uso, facilitadores, } \\
\text { barreiras }\end{array}$ & 15 & $11-18$ & $\begin{array}{c}\text { Jovens } \\
\text { deficientes } \\
\text { (incluindo } \\
\text { sujeitos com } \\
\text { LCA) }\end{array}$ & $\mathrm{N} / \mathrm{C}$ \\
\hline
\end{tabular}


continuação

\begin{tabular}{|c|c|c|c|c|c|c|}
\hline \multirow[b]{2}{*}{$\mathbf{N}^{\mathbf{o}}$} & \multirow[b]{2}{*}{ Data Autor } & \multirow[b]{2}{*}{ Palavras chave } & \multirow[b]{2}{*}{ Amostra (n) } & \multirow[b]{2}{*}{ Faixa etária* } & \multicolumn{2}{|c|}{ contmu } \\
\hline & & & & & População** & Mídia* \\
\hline 9 & 2011, Wade & $\begin{array}{c}\text { Adolescentes, lesão } \\
\text { cerebral traumática, } \\
\text { telesaúde, } \\
\text { intervenções } \\
\text { comportamentais }\end{array}$ & 41 & 11-18 & $\begin{array}{l}\text { Adolescentes } \\
\text { com TCE e } \\
\text { familiares }\end{array}$ & Ss \\
\hline 10 & 2010, Kilov & $\begin{array}{l}\text { Adolescente, } \\
\text { comunicação, chatroom, } \\
\text { internet, computador, } \\
\text { lesão cerebral }\end{array}$ & $\mathrm{N} / \mathrm{C}$ & $\mathrm{N} / \mathrm{C}$ & $\mathrm{N} / \mathrm{C}$ & $\mathrm{N} / \mathrm{C}$ \\
\hline 11 & 2010, Wade & 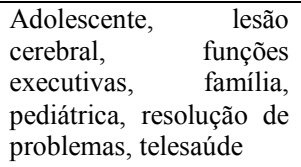 & 137 & $11-18$ & $\begin{array}{l}\text { Adolescentes } \\
\text { com TCE e } \\
\text { familiares }\end{array}$ & Ss \\
\hline 12 & 2009 , Young & $\begin{array}{lr}\text { Criança; } & \text { adolescente; } \\
\text { questionário } & \text { online; } \\
\text { deficiência; avaliação; } & \text { qualidade de vida }\end{array}$ & 69 & $8-13$ & $\begin{array}{c}\text { Crianças e } \\
\text { adolescentes } \\
\text { com } \\
\text { deficiência. }\end{array}$ & Ss \\
\hline 15 & 2008, Wade & $\begin{array}{lr}\text { Lesão } & \text { cerebral } \\
\text { adquirida; } & \text { intervenção; } \\
\text { resolução de problema. }\end{array}$ & 9 & $10-18$ & $\begin{array}{c}\text { Crianças e } \\
\text { adolescentes } \\
\text { com TCE e } \\
\text { familiares }\end{array}$ & Ss \\
\hline 16 & 2005, Wade & $\begin{array}{l}\text { Telesaúde; lesão cerebral } \\
\text { adquirida; intervenção; } \\
\text { resolução de problema; } \\
\text { online. }\end{array}$ & 6 & $5-16$ & $\begin{array}{c}\text { Crianças e } \\
\text { adolescentes } \\
\text { com TCE e } \\
\text { familiares }\end{array}$ & Ss \\
\hline 17 & 2004, Wade & $\mathrm{N} \backslash \mathrm{C}$ & 6 & $6-15$ & $\begin{array}{l}\text { Crianças e } \\
\text { adolescentes } \\
\text { com TCE e } \\
\text { familiares }\end{array}$ & Ss \\
\hline
\end{tabular}

Ss- softwares sócias; SRS - sites de redes sociais; N/C - não consta.

** TCE = Traumatismo Crânio-Encefálico. LCA = Lesão Cerebral Adquirida

Fonte: PubMed; Psyc INFO e ERIC, 2015

Se olharmos para todas as publicações, como um conjunto, uma preocupação

latente está presente em todos os estudos: como incorporar os recursos da comunicação

remota aos programas de tratamento de crianças e adolescentes com lesão cerebral, o

que não necessariamente significa como incorporar sites de relacionamento social. Há o

reconhecimento da importância da utilização comunicação mediada pelo computador 
em reabilitação, mas não há um consenso e caminho para atingir tal objetivo. A quase totalidade dos estudos é justificada pelas características dos modos urbanos de vida (por exemplo, falta de tempo, problemas em conciliar agenda de pais e filhos); ou, ainda, pela dificuldade de acesso de certas populações aos grandes centros de tratamento associada ao custo social dos programas que, de maneira geral, se fazem preponderantes na vida do sujeito.

\subsection{Reabilitação on-line}

A maioria das fontes localizadas (65\%) tem como meta de estudo o desenvolvimento de modelos de tratamento a distância para adolescentes com lesão cerebral (Textos:1,2,5,8,9,11,13,14,15,16,17). Com esse objetivo, alguns programas de intervenção on-line são comparados à terapia tradicional face a face e os achados preliminares indicam que os resultados alcançados no tratamento on-line são semelhantes aos presenciais e, mais do que isso, teriam várias vantagens sobre o tratamento convencional. A acessibilidade é vista como uma das principais vantagens, uma vez que os serviços on-line podem ser acessados em casa, ou em outro ambiente, quando a família e o adolescente estão disponíveis, o que minimiza barreiras e aumenta a frequência à adesão. Além disso, todos podem dispor de mais tempo terapêutico, uma vez que podem rever os materiais on-line repetidamente, sem conciliar os horários com o terapeuta. Alguns desses estudos comparam diferentes modelos de tratamento on-line, a intervenção acompanhada a distância por uma equipe de terapeutas da reabilitação com o uso orientado da WEB que fornecem informações gerais sobre lesão cerebral, grupos de discussão abertos, bancos de perguntas e respostas sobre manejo comportamental após o trauma de crânio (Textos:1,2,5,8,9,11,14). Em tese, essa 
modalidade de acesso baseada fundamentalmente na disponibilidade de informação poderia ajudar as famílias a superarem algumas dificuldades enfrentadas com o filho adolescente.

A estrutura da intervenção on-line, de maneira geral, é muito bem desenhada e justificada no que se refere às necessidades dos adolescentes com lesão cerebral. São programas de tratamento com ênfase no desenvolvimento de habilidades de autoconhecimento, autorregulação, planejamento e resolução de problemas. Ela incorporou em seu desenho a linguagem pragmática e o processamento social da informação para trabalhar dfasagens na competência social após o o traumatismo de crânio.

Apesar de concebido para o acompanhamento on-line, o desenho desses projetos é muito similar ao tratamento off-line. É um software com número estabelecido de sessões a serem realizadas, metas a serem alcançadas, etapas predeterminadas a serem vencidas, dentro de diferentes habilidades que podem estar alteradas em função da lesão cerebral. Essa intervenção combina o conteúdo do tratamento com videoconferência para comunicação equipe-família e sessões de terapia off-line. Os programas podem ser individualizados, a depender do desenvolvimento de cada adolescente, mas com fluxos e processos de trabalho fechados. Técnicas de autoavaliação são utilizadas ao término de cada etapa, e toda a família é envolvida no processo.

Os estudos dos programas de tratamento on-line são muito consistentes. A maioria são ensaios clínicos randomizados com follow-up em média entre seis e dezoito meses, no entanto, existem fatores limitantes, no que se refere à expansão desses projetos: todos os estudos foram feitos com equipamentos e com sinal de internet cedidos às famílias pelos financiadores das pesquisas, esses benefícios foram retirados após o término dos estudos. Apesar de esses projetos serem legítimos e consistentes no 
campo da investigação, apresentam clara distância entre teoria e prática, o que em educação é extremamente questionável.

\subsection{Padrões de uso, segurança e educação}

Os estudos exploratórios (Textos:3,4,7) e o artigo de revisão (Texto:10), até pela característica da investigação, levantam questões gerais muito ponderadas, como padrões de uso das redes sociais, fatores relacionados a segurança, cyberbullying e privacidade para evitar expor o adolescente com lesão cerebral nas redes sociais e

minimizar riscos. E, por último, apontam para a necessidade de programas educacionais para uso seguro da web.

Quanto aos padrões de uso, houve um artigo que descrevia o uso de computador, e-mail e internet associado às habilidades de pessoas com lesão cerebral, aos quadros de afasias e a dificuldades cognitivas (Texto:10). Por outro lado, um estudo com jovens com lesão cerebral descreve um padrão nada específico de navegação na internet em geral e nos sites de redes sociais dessa população. Jovens com deficiência relataram o uso de uma variedade de redes on-line como e-mails, sites de mensagens instantâneas (para conversar com uma ou várias pessoas em tempo real), sites de redes sociais como o MySpace e o Facebook, uso de jogos on-line, bem como aqueles baixados e jogados off-line. Gostavam de navegar em sites de esportes, tais como os de clubes de futebol e de netball, locais para encontrar informações sobre jogos e pontuações. Além disso, referiram o uso da internet para várias atividades, incluindo trabalhos da escola, lazer e recreação, e construir conexões sociais (Texto:7). Amigos e irmãos têm um papel importante em apoiar o adolescente a formar seu perfil nas redes sociais e em outros sites. 
No entanto, o que diferencia o padrão de uso são as regras da família que, diferentemente do que fazem com o filho sem deficiência, tentam assegurar que a lista de amizade on-line do filho deficiente seja checada, especialmente nos sites de redes sociais, e isso de alguma forma limita o filho a se conectar somente com as pessoas que os pais conhecem e nas quais eles sentem que podem confiar (Textos:7,10).

A discussão sobre segurança e exposição nos sites de redes sociais não é específica dos adolescentes com lesão cerebral, ela é muito mais ampla, e as próprias configurações desses ambientes não foram desenhadas para garantir a privacidade, mas, ao contrário, para garantir a exposição e a interlocução e o acesso à informação. No entanto, outras variáveis se somam a essa análise, quando falamos de adolescentes com lesão cerebral. Em tese, a vulnerabilidade desse adolescente está associada a um padrão de desinibição e impulsividade comportamental e à dificuldade de julgamento e análise das relações sociais, sintomas muito frequentes após a lesão cerebral.

Os estudos deste levantamento trazem um dilema ético e também limitações metodológicas associadas à utilização de sites de redes sociais com adolescentes com lesão cerebral (Textos:4,10). O tema é mais comumente associado ao risco do que ao benefício (por exemplo, exposição a predadores e a conteúdo inapropriado, distração dos trabalhos escolares, mentiras sobre a própria identidade). No entanto, há o debate, ainda que muito reservado, sobre os mitos relacionados às consequências negativas e aos riscos associados ao uso desses ambientes por adolescentes.

A necessidade de programas educacionais a respeito de modelos de uso da internet para adolescentes com lesão cerebral é tratada de forma direta em alguns artigos pesquisados (Textos:4,6,7,10), e de forma indireta em outros, como meio de viabilização de diferentes modelos de tratamento (Textos:1;2;5;8,9;12;13;14;16;17). Essa necessidade não se restringe ao adolescente, porém diz respeito a um espectro mais 
amplo de pessoas envolvidas no cotidiano desses adolescentes (por exemplo, familiares, profissionais de saúde, professores). Sugere-se que esses programas sejam adaptados às habilidades exigidas nos vários meios de relacionamento on-line (Texto:10). Por exemplo, diferentemente das habilidades requeridas para responder a um e-mail, o uso de sites de redes sociais tem demandas linguísticas, cognitivas e requerem, ainda, percepção de sinais subjetivos de mudança de comportamento (Texto:10).

Um estudo sobre sujeitos com deficiência, incluindo aqueles com lesão cerebral adquirida (Texto:6), o qual investiga a eficácia da intervenção educativa individualizada para facilitar o uso e a participação social dos jovens com deficiência nos sites de relacionamento social de forma segura, demonstra que programas educativos contextualizados podem trazer mudanças objetivas, como performance de uso e subjetivas, como satisfação pessoal. O benefício de programas educativos de utilização segura das redes sociais não estaria restrito à população com deficiência, no entanto, existem especificidades desses projetos quando destinados à população com e sem alterações neurocognitivas e comportamentais.

\subsection{Sites de redes sociais}

Sites de redes sociais podem ser definidos como um serviço na web que permite aos indivíduos construir um perfil público ou semipúblico dentro de um sistema limitado; articular uma lista de outros usuários com quem eles compartilham uma conexão; e navegar na sua lista de ligações, postagens feitas por outros dentro do sistema. A natureza e a nomenclatura dessas conexões podem variar de site para site (BOYD; ELLISON, 2007).

O que torna os sites de rede social únicos não é apenas a possibilidade de fazer 
novos contatos, mas sim permitir que os usuários articulem e tornem visíveis ou não as suas redes sociais. Isso pode resultar em conexões entre indivíduos que de outra forma não poderiam ser feitas. Existem outras formas de comunicação mediadas pelo computador que não necessariamente se configuram como redes de relacionamento. Os sites de redes sociais seriam, então, uma categoria do grupo de softwares sociais.

De toda a bibliografia levantada sobre o tema, apenas em três artigos (Textos:6,7,10) o objeto de estudo era o uso que adolescentes com deficiência, incluindo aqueles com lesão cerebral, faziam de sites de rede social. Um artigo explora a questão da imaginação e criatividade de crianças e adolescentes com deficiência ao responder questionários on-line (Texto:12). Dois outros artigos exploraram o tema "sites de rede social" (Textos: 3,4 ) na perspectiva do profissional que trabalha com sujeitos com lesão cerebral, e os restantes (Textos:1,2,5,8,9,12,13,14,16,17) tratavam da comunicação mediada pelo computador com uso de webcam (Skype, videoconferência ou outros aplicativos), o que é um avanço na área da saúde, em geral, e da reabilitação, em específico, mas completamente diferente do uso de um site de redes sociais em programa de reabilitação.

O objetivo desta revisão foi demarcar o ineditismo da investigação proposta, a partir do mapeamento do estado da arte do uso de redes sociais como instrumentos de apoio à reabilitação de adolescentes com lesão cerebral. Outro objetivo importante foi identificar, nas fontes de dados da literatura da área de saúde, educação e psicologia, estudos sobre o uso de sites de redes sociais em reabilitação com adolescentes com lesão cerebral, suscetíveis de subsidiar nosso trabalho. A partir desta revisão, foi possível integrar as informações de um conjunto de pesquisas realizadas na área, bem como identificar temas que ainda necessitam de evidências, auxiliando na orientação para investigações futuras. 
Esta revisão bibliográfica evidenciou uma total escassez de literatura na área de uso de redes sociais em reabilitação, o que coloca em evidência a pertinência dessa investigação de doutorado. Os bancos de dados pesquisados e os termos de busca foram selecionados de forma que pudéssemos ter a maior abrangência na pesquisa. No entanto, parece haver falta de consenso na terminologia da literatura para descrever o meio de comunicação de interesse neste estudo.

Após análise detalhada das fontes localizadas, podemos concluir que os sites de redes sociais ainda não foram incorporados aos programas de reabilitação de adolescentes com lesão cerebral, donde o ineditismo da nossa proposta de estudo. As ferramentas de mídias sociais são sistemas projetados para possibilitar a interação social a partir do compartilhamento e da criação colaborativa de informação nos mais diversos formatos (RECUERO, 2009). Existe um grupo extenso de mídias sociais construídas com base nos fundamentos tecnológicos da Web 2.0 e que permitem a criação e a troca de conteúdo gerado pelo utilizador. Essas mídias sociais podem ter diferentes formatos, como blogs, compartilhamento de fotos, videologs, scrapbooks, e-mail, mensagens instantâneas, compartilhamento de músicas, crowdsourcing, VoIP, entre outros. Os estudos apresentados que utilizavam a comunicação mediada pelo computador não incorporavam elementos fundamentais na forma de diálogo nas redes sociais, como sistemas que permitem a construção de um perfil pessoal, a interação através de comentários e a exposição pública da rede de relacionamentos de cada ator, elementos característicos desse ambiente. Os trabalhos utilizam sim uma forma de comunicação mediada pelo computador, mas em um esquema de relação predefinido e hierárquico, dentro de um conjunto fechado de prerrogativas (Textos: 1,2,5,8,9,12,13, 14,16,17).

Por outro lado, existe na literatura o reconhecimento dos profissionais da saúde, dos próprios adolescentes, dos seus familiares e dos pesquisadores em relação à 
relevância do tema (Textos:6,7,10). Entretanto, há uma insegurança baseada, sobretudo, no não se saber como fazê-lo, no temor da exposição e do risco social desse adolescente. São preocupações importantes e fundamentadas nas características cognitivas e comportamentais desses jovens.

O debate e a contraposição frequentemente registrados no campo das ciências sociais aplicadas à saúde não é um fato recente. A aproximação dessas áreas de estudo tem repercussões fundamentais na adequação dos programas educacionais em reabilitação. Nos últimos dez anos, em sentido contrário do ocorrido na área da educação, as publicações sobre as mídias sociais e a aprendizagem no campo da saúde foram pouco exploradas. Por um lado, as mídias vão sendo incorporadas cada vez mais às nossas vidas e de forma mais precoce a cada geração, e, por outro, uma lacuna de conhecimento pode se abrir.

Nesse estágio do conhecimento, as investigações qualitativas e retrospectivas são bastante esclarecedoras e trazem bases importantes para pesquisas futuras e isso foi muito bem caracterizado nos poucos estudos que localizamos nesse sentido. Jovens com deficiência podem sim aprender a usar a internet para construir redes sociais com seus pares, com familiares e amigos; para desenvolver o uso dessa ferramenta, sugere-se a intervenção individualizada e sob medida para facilitar a participação social dessa população no meio midiático: as famílias precisam de treinamento no conhecimento de informática e internet, e de apoio para que adquiram consciência dos potenciais benefícios das tecnologias na reabilitação; e como esses jovens podem ainda apresentar problemas básicos de letramento digital, de alguma forma essa questão precisa ser abordada, para aumentar ainda mais o uso seguro e bem-sucedido de redes sociais na internet. 
Com base nos achados das pesquisas sobre o uso de redes sociais em saúde, concluímos, neste levantamento, que trata-se de um tema de pesquisa não explorado, original na sua concepção, posto que não há na literatura especializada nenhuma experiência acerca do uso dessa ferramenta em situação de reabilitação de jovens com lesão cerebral. Por essa razão, há potencial para expandir as fontes da literatura e os programas educacionais na área, a fim de permitir que as populações com lesão cerebral possam usar esses novos ambientes de comunicação de forma efetiva. Um projeto dessa natureza não apenas os capacitaria a participar de fóruns sociais e educacionais, como também poderia contribuir para aumentar o sentimento de pertencimento, reduzir a sensação de isolamento, minimizar estigmas e a vulnerabilidade social. 


\section{SITES DE REDES SOCIAIS: ESTRUTURA, HISTÓRIA E APLICAÇÃO EM EDUCAÇÃO}

Neste capítulo, abordaremos aspectos econômicos, estruturais, históricos e acadêmicos relacionados aos sites de redes sociais (SRSs). Começamos por definir o que constitui um site de rede social, suas principais características e, em seguida, apresentamos uma perspectiva sobre a breve história do seu intenso desenvolvimento. Fechamos esta sessão apresentando alguns estudos sobre a utilização educacional e as perspectivas dos SRSs, especificamente no ambiente escolar.

\subsection{Web.1 e Web.2}

A história dos sites das redes sociais talvez esteja muito mais identificada com questões econômicas do que educacionais. Inclusive a apropriação desse ambiente, como espaço coletivo de construção de conhecimento e intenções de grupo, não se dá ao acaso, não é fruto da análise dos educadores, mas um fenômeno que nasce da iniciativa de jovens, com pequenas em presas e grandes ideias e, posteriormente, é alavancada pelos economistas. O termo "bolha" é um apelido dado pelo mercado financeiro em referência ao superaquecimento de um determinado ativo. O sentido é que uma bolha acaba por inflar, causada por movimentos especulativos, cujas consequências econômicas costumam ser devastadoras para o setor por ela atingido.

A formação da chamada bolha da internet ocorreu entre 1995 e 2000 e foi um fenômeno muito relevante no mundo tecnológico. Quando a situação veio à tona, o desenvolvimento tecnológico não tinha atingido o nível que conhecemos hoje. Poucas pessoas usufruíam da internet e as redes sociais ainda não faziam parte do cotidiano dos 
usuários. No entanto, as perspectivas eram grandes e muitos investidores fizeram aportes altos em empresas da área, ${ }^{5}$ somando lucros absurdos com o crescimento da bolha. O mercado virtual não parava de inflar e novas empresas, organizações não governamentais, estatais e tantos outros segmentos acabaram também entrando no mundo tecnológico.

Entende-se que o marco que representa a fronteira entre o passado e o presente da vida da internet, digamos assim, foi o estouro da bolha.com, nome dado à grande desvalorização das ações das empresas de tecnologia em 2001. O fenômeno foi sinônimo de prejuízo para muitos investidores do mundo tecnológico. No entanto, foi um fato bastante importante para que a internet ganhasse grandes proporções nos anos seguintes e, principalmente, de forma mais consolidada (O’REILLY, 2005).

Com esse quadro, o mercado financeiro ficou em uma espécie de latência, e mesmo com o estouro da bolha.com e todas as suas consequências, a internet continuava viva; as inovações e o desenvolvimento tecnológico, curiosamente, seguiam em frente, ainda que com maior dificuldade de financiamento. Esse fato foi marcante e, paradoxalmente, a web estava mais importante do que nunca, apresentando novas e instigantes aplicações, com sites eclodindo com surpreendente regularidade. Ou seja, foi no ápice do evento negativo que nasceram as principais mudanças que indicariam que, ao contrário do que o mercado financeiro supunha, a web se transformaria, a internet mostraria a sua força e as empresas sobreviventes ao colapso passariam a ser foco de estudo e interesse dos investidores e programadores da área.

\footnotetext{
${ }^{5}$ Entre elas MSN-Hotmail, Google, Yahoo e Amazon.
} 
Foi em meio a esse contexto que o conceito de Web 2.0 foi desenvolvido e proposto pela primeira vez de forma inédita e pública (O’REILLY, 2005). Longe de um consenso, na ocasião, desenhou-se um esboço sobre o paralelo comparativo entre Web1.0 e o que viria a ser a Web 2.0. Sairíamos de uma web centralizada para um sistema inteligente compartilhado e coletivo. A nova web não iria apenas mediar sujeitos, mas muito além, ela em si teria características de inteligência que iria nos rastrear, ser também mediadora, nos fazer sugestões, classificar nossos interesses e cruzar eventos. o conhecimento não seria mais centralizado, mas sim construído, e os textos seriam publicados e escritos coletivamente. Talvez estivesse nascendo ali um ambiente que poderia futuramente ser apropriado pelo sistema educacional.

Em síntese, após a crise a internet evoluiu. Vimos nascer, no início dos anos 2000, um sistema mais aberto e colaborativo que, sem dúvida, é o território sobre o qual os websites de redes sociais irão se consolidar. Os anos precoces da história das redes sociais antecedem esse movimento, mas a sua expansão é diretamente relacionada aos conceitos e novos recursos da Web 2.0. Algumas características marcam o ecossistema personalizado de um site Web 2.0 (CORMODE GRAHAM; BALACHANDER KRISHNAMURTHY, 2013):

- Incorpora um forte componente social. Os usuários são concebidos como o primeiro foco do sistema com páginas de perfil em destaque incluindo características tais como: idade, sexo, localização, depoimentos ou comentários sobre o usuário por outros usuários;

- proporciona a capacidade de novas conexões entre os usuários por meio de links ou amigos, a adesão em grupos com diferentes interesses e as assinaturas ou feeds RSS com atualizações de outros usuários; 
- possibilita a postagem de conteúdo com formatos variados: fotos, vídeos, blogs, comentários, avaliações sobre o conteúdo de outros usuários e alguma autonomia para controlar sua privacidade e seu nível de compartilhamento;

- e, por fim, outras características mais técnicas que estão relacionadas à disponibilidade de Application Programming Interface (API) ${ }^{6}$ para adição de vários tipos de conteúdo por terceiros (por exemplo, vídeos no formato Flash), e a comunicação com outros usuários por meio de e-mail ou sistemas de mensagem instantânea.

\subsection{A estrutura e as especificidades dos sites de redes sociais}

Existe uma grande diferença entre a comunicação mediada pelo computador e um site de redes sociais. Os sites são uma consequência da apropriação pelos internautas das ferramentas de comunicação mediada pelo computador; são espaços utilizados para a expressão das redes sociais na internet (RECUERO, 2009), entretanto, ambos não se confundem.

\footnotetext{
${ }^{6}$ API, Application Programming Interface (em português: Interface de Programação de Aplicação) é um conjunto padronizado para programação de procedimentos, funções e chamadas, fornecidos por aplicações e sistemas operacionais para que outros sistemas utilizem seus recursos e serviços. Desta forma o programador do sistema consumidor não necessita conhecer os detalhes de implementação do que deseja utilizar, apenas os parâmetros de entrada e saída, diminuindo assim o tempo de desenvolvimento, entretendo mantém-se uma dependência do sistema fornecedor. Como exemplo, o mapa do Google (googlemaps), que fornece a outros sistemas, por meio de API, os recursos de mapa e geolocalização.
} 
Neste estudo, utilizamos a definição de sites de redes sociais como serviços baseados na web que permitem aos indivíduos: (1) construir uma persona por meio de um perfil ou página pessoal dentro de um sistema limitado; (2) compartilhar conexões por meio de comentários $;^{7}$ e (3) visualizar uma lista de ligações pessoais e navegar sobre aquelas construídas por terceiros dentro de um dado sistema (BOYD; ELLISON, 2007). A natureza e a nomenclatura desses recursos podem variar de site para site, porém o princípio se mantém. Essa conceituação foi apresentada neste estudo quando realizamos o levantamento acerca do uso de redes sociais em reabilitação, no qual evidenciamos que o uso da comunicação mediada pelo computador não se configurava em uma rede social de relacionamentos (ver Capítulo5).

Frequentemente os encontros nas redes sociais são entre sujeitos que mantêm laços latentes, que compartilham algum nível de interesse comum, de conexão off-line e que já fazem parte de sua rede social mais extensa (HAYTHORNTHWAITE, 2005).

Apesar da implementação de uma variedade enorme de interfaces, a nossa impressão é que a espinha dorsal dos sites continua sendo os perfis visíveis, públicos, nos quais é exposta, inclusive, uma lista articulada de amigos que também são usuários do sistema. O perfil de um usuário é gerado por meio de respostas simples, que incluem descritores como idade, local de moradia, nascimento e uma seção "sobre mim”, de interesses pessoais. A maioria dos sites também incentiva os usuários a fazer upload de uma foto de perfil. Para aprimorá-lo, alguns sites permitem que os usuários adicionem

\footnotetext{
${ }^{7}$ Comentários dentro de uma rede social na internet não se restringem a escrita, mas há toda uma gama de interações (matéria-prima das relações e dos laços sociais) que utilizam qualquer interface disponível no software social, como fotos, vídeos, ícones, entre outras.
} 
conteúdo multimídia ou modifiquem a aparência e os sentimentos do seu perfil. Um perfil poderia ser compreendido como um modo de apresentação por meio de uma plataforma eletrônica; mas, mais do que isso, são páginas exclusivas onde, por meio desta digitação, me torno pessoa (BOYD; ELLISON, 2007, apud Sunde N, 2003, p. 3).

A visibilidade de um perfil varia conforme o site e de acordo com o critério definido pelo utilizador. Sistemas de rastreamento propõem novas conexões aos usuários, a ideia é sempre aumentar a rede de relações. As variações estruturais em torno de visibilidade de acesso são uma das principais formas pelas quais os sites se diferenciam uns dos outros.

Os rótulos dos relacionamentos estabelecidos na internet podem incluir, entre outros, amigos, contatos e fãs. Para fazer novos amigos, na maioria dos sites, exige-se confirmação bidirecional; contudo, não é uma regra. Laços unidirecionais são rotulados como seguidores ou fãs, mas também podem ser chamados de amigos. O uso do termo "amigo" pode ser confundido, porque não significa, necessariamente, um laço de amizade, e as razões para as pessoas se conectarem são variadas (RECUERO, 2009), mas isso não é uma especificidade das relações nos sites de redes sociais.

De maneira geral, o sequenciamento das interações em uma rede social se dá por meio de comentários. Esses comentários são rastros de diálogos que se somam com opiniões favoráveis ou desfavoráveis às postagens feitas. Esse recurso funciona como um diálogo aberto. Além das postagens abertas, os sites têm, muitas vezes, um recurso de mensagens privadas semelhante ao webmail. Ambos, mensagens e comentários privados, são extremamente populares, mas não são universalmente disponíveis.

Dentro da complexidade da comunicação entre seus usuários, a interface se apresenta de maneira silenciosa, mas essencial. Por exemplo, ao entrar em um site pela primeira vez o usuário precisa dominar elementos da interface digital, tais como: onde 
introduzir um texto, como enviá-lo, para quem será enviado, quem poderá ou não ter acesso a ele. Esses elementos constituem, por sua vez, objetos de mediação da comunicação no ciberespaço. O discurso dos internautas será influenciado por suas características e sua significação envolve, assim, a sua apreensão (JOSÉ; CINTRA, 2003). De maneira geral, essas interfaces são muito intuitivas e a curva de aprendizagem desses dispositivos é muito rápida. No entanto, essa apropriação é bem mais profunda do que simplesmente aprender comandos, envolvendo, assim, todo o espectro da cultura da comunicação remota.

Muitas vezes, esperamos das artes do virtual um fascínio espetacular, uma compreensão imediata, intuitiva e sem cultura. Como se a novidade do suporte devesse anular a profundeza temporal, a espessura do sentido, a paciência da contemplação e da interpretação. Contudo, a cibercultura não é, justamente, a civilização do zapping. Antes de encontrar o que procuramos na World Wide Web é preciso aprender a navegar e familiarizar-se com o assunto. Para integrar-se a uma comunidade virtual é preciso conhecer seus membros e faz-se necessário que eles o reconheçam como um dos seus. As obras e os documentos interativos, em geral, não fornecem nenhuma informação ou emoção imediata se não thes forem feitas perguntas, se não lhes for dedicado um tempo para percorrê-los ou compreendê-los, permanecerão selados. (LÉVY, 1999, p.68).

A formação da cultura de uma comunidade virtual é muito interessante e parece ter vida própria, distanciando-se facilmente da sua concepção. Muitos sites têm como grupo-alvo pessoas de regiões geográficas específicas ou mesmo grupos linguísticos, embora isso nem sempre determine o círculo dos usuários do site. O Orkut, por exemplo, foi lançado nos Estados Unidos com uma única interface em inglês, mas foram os brasileiros que se tornaram rapidamente o grupo dominante de usuários (BOYD, 2006). O fato de alguns sites serem projetados com orientação específica, seja 
étnica, religiosa, política ou outras categorias de identidade, não garante totalmente a segmentação da sua apropriação pelos usuários. Existem ainda situações, talvez seja o que ocorra com a maioria dos sites, em que as redes sociais são concebidas para serem amplamente acessíveis, no entanto, por algum fenômeno, atraem populações homogêneas e, dessa forma, não é raro encontrar grupos segregando-se por nacionalidade, idade, nível de escolaridade ou outros fatores de segmentação dos seus usuários (STALD, 2008). Em síntese, é o poder da interação entre os usuários no ambiente on-line que impulsiona o formato da rede de relacionamentos, direciona o seu sucesso, o seu fracasso e a sua vulnerabilidade.

\subsection{Breve história dos sites de redes sociais}

É muito difícil precisar quando surgiu o primeiro site de redes sociais, mesmo porque a sua história se caracteriza por transformações conceituais e pelo constante aprimoramento de recursos tecnológicos. Conforme descrito acima, a Web 2.0 agrupa uma combinação de inovações na internet, mas não há uma definição precisa do seu significado, do seu alcance e nem seria útil usar uma etiqueta binária 1.0 e 2.0 para categorizar todo um movimento de comunicação que foi ou viria pela frente (GRAHAM; KRISHNAMURTHY, 2013).

De acordo com os conceitos abordados neste capítulo, poderíamos dizer que o SixDegrees foi o primeiro site de rede social que reuniu uma série de recursos que hoje caracterizam esse ambiente. Seu nome faz referência aos seis graus de amizade, ou seja, pressupõe que a cada seis pessoas que conhecemos, existe um amigo em comum. Esse site foi lançado em 1997 e, na ocasião, permitia aos usuários criar perfis, listar os amigos e, a partir de 1998, disponibilizou a possibilidade de o usuário navegar em uma 
lista de amizades. Esses recursos já haviam sido lançados antes, no entanto, de forma isolada. Por exemplo, naquela ocasião os perfis eram utilizados em sites para encontrar parceiros; em 1996, o AIM e o ICQ de mensagens instantâneas mantinham uma lista de amigos para os usuários, embora não fossem visíveis; em 1995, o Classmates.com ajudava pessoas filiadas à sua escola ou faculdade a encontrar antigos colegas de primeiro ou segundo grau, ou mesmo colegas de faculdade anos depois do seu término, mas os usuários não podiam criar perfis ou lista de amigos até anos mais tarde. O fato é que o SixDegrees foi o primeiro a combinar todos esses recursos de forma inédita. Ele lançou no mercado a onda de conectar-se e enviar mensagens em uma rede, atraiu milhões de usuários, mas não se tornou um negócio sustentável e, em 2000, o serviço simplesmente foi encerrado. Seus fundadores levantaram a hipótese de que ele estivesse à frente do seu tempo.

Conforme citado acima, nem todo site de rede social começa de forma semelhante e segue um curso linear. Ao contrário, na maioria das vezes a rede configura-se em mutação, pois toma formas variadas na medida do fluxo de comunicação entre os seus usuários e das características da sua estrutura. Por exemplo, QQ começou como um serviço chinês de mensagens instantâneas; o LunarStorm surgiu como um site da comunidade; o Cyworld, como um fórum de discussão coreano; e o Skyrock (anteriormente Skyblog), como um serviço de blogs francês, antes de utilizar recursos dos sites de rede social (BOYD; ELLISON, 2007).

A Figura 2 representa o lançamento de uma série de grandes sites de redes sociais, ao longo dos anos, além de alguns relançamentos com novos recursos e configurações. Entre 2002 e 2005 muitos sites novos foram lançados. Nessa ocasião, muitos projetos assumiram a fórmula de sites focados em perfis, tentando repetir o sucesso inicial de Friendster ou, até mesmo, tentando atingir grupos demográficos 
específicos. Enquanto os sites que eram focados em populações específicas procuravam atrair um vasto grupo de usuários, sites profissionais como LinkedIn, Visible Path e Xing focaram no interesse profissional e ficaram conhecidos por empresários.

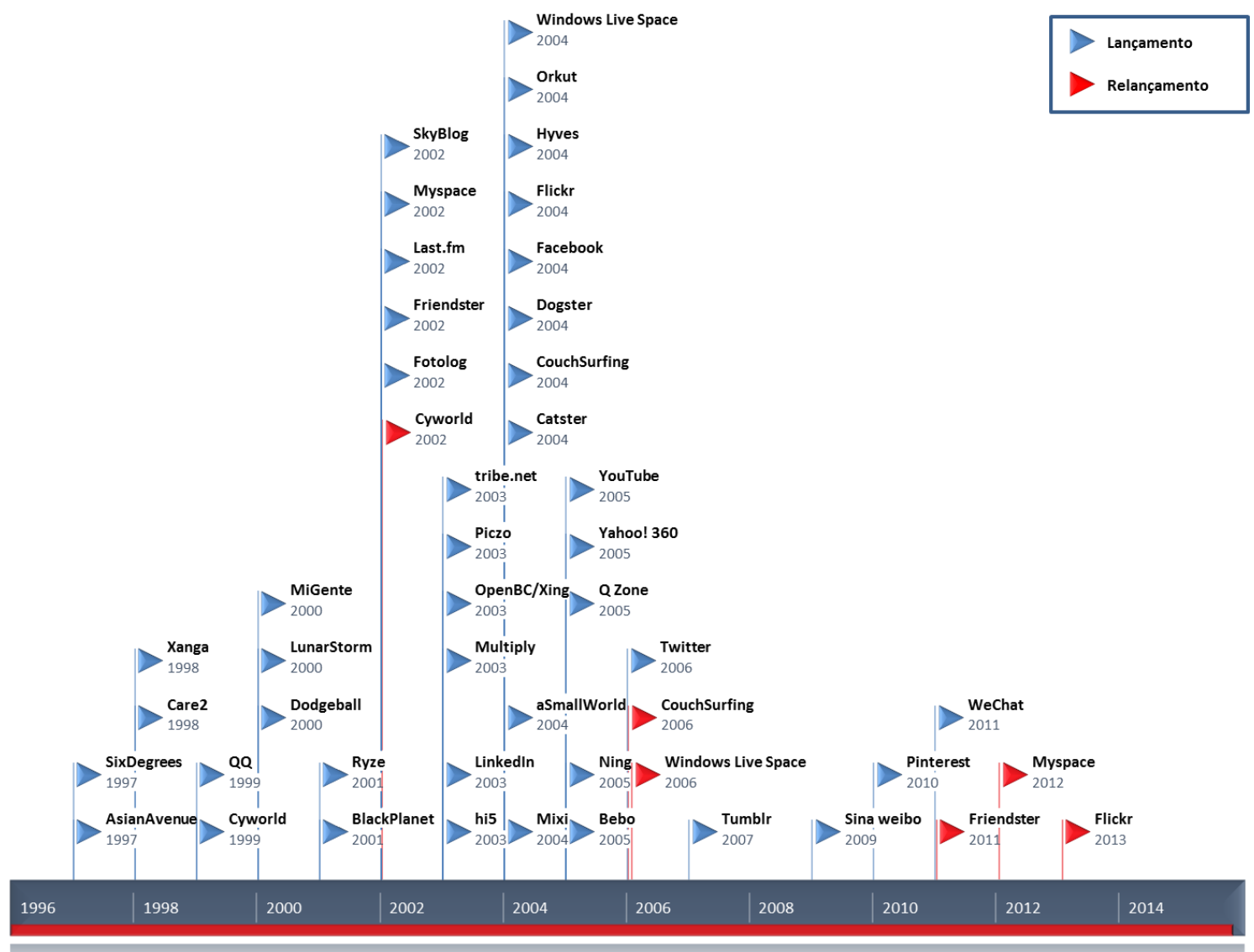

Figura 2 - Linha do tempo dos principais sites de rede sociais 1996-2014

(fontes: BOYD, 2007; STALD, 2008 e pesquisas abertas aos próprios sites na Internet)

Em paralelo a esse movimento, foram desenvolvidos sites para os apaixonados por causas específicas, como Dogster e Catser, para os defensores das causas dos animais, que ajudam a conectar desconhecidos com base em interesses comuns; o Care2, que ajuda ativistas a se conhecerem e se encontrarem; o Couchsurfing, que conecta viajantes a donos de sofás disponíveis para hospedagem; e o MyChurch, que 
junta as igrejas cristãs aos seus membros; enfim, uma série de comunidades e interesses vêm à tona em uma possibilidade de organização social inteiramente inédita.

Enquanto as mídias sociais se desenvolviam e a onda do conteúdo gerado pelo usuário crescia, alguns websites focados em compartilhamento de mídia começaram a implementar funções que caracterizam os sites de redes sociais, chegando mesmo a se transformarem em verdadeiras redes de relacionamento. Exemplos pontuais e muito difundidos, inclusive no Brasil, são o Flickr, para compartilhamento de fotos; o Last.fm, para quem tem o hábito de ouvir música; o YouTube, para compartilhamento de vídeos; entre muitos outros mais atuais.

Se pensarmos na extensão e no significado do surgimento dessas redes, facilmente podemos dizer que acertaram na inclusão. Talvez, este não tenha sido o foco, mas foi o alvo atingido. O tempo, a localização, a idade, as desigualdades, as coletividades, sejam quais forem, passam então a ter outras possibilidades de organização nas redes sociais.

Ainda há certa polaridade quanto ao futuro dos sites de redes sociais. Essa polaridade vai muito além do simples fato de uma comunidade migrar de um site para outro, pois isso caracteriza a vida dessa ferramenta e não seus limites. Estudiosos da área consideram que em 2012, passado o grande período de boom das redes sociais, ela enfim supera a visão de algo passageiro, para desempenhar um papel efetivo como ferramenta de comunicação em tempo real e coletivo. Finalmente, qualquer pessoa que deseje criar um site de rede social de nicho pode fazê-lo, existem plataformas que incentivam os usuários a criar a sua própria rede.

Atualmente, não há dados precisos sobre quantas pessoas usam as redes sociais, embora pesquisas de marketing indiquem que é um setor que cresce em popularidade. No Brasil, em 2014, acompanhamos um grande desenvolvimento no cenário digital, 
com isso, a audiência das redes sociais vem crescendo e se tornando cada vez mais relevante. Hoje, o Brasil lidera algumas estatísticas de uso dos sites na população geral: é o país latino com maior número de visitantes únicos diários em redes sociais; é responsável por $10 \%$ do tempo total consumido globalmente em redes sociais, ocupando o segundo lugar no ranking; o número de fãs em páginas do Facebook cresceu 179\% entre janeiro de 2013 e junho de 2014 (VIEIRA, 2005). No Brasil, década de 1970 vários projetos têm sido desenvolvidos por centros universitários, órgãos públicos e mesmo a implementação de políticas públicas, com alcance em diferentes setores da sociedade, para difusão das tecnologias (LACERDA SANTOS, G.; GALÁN, J., 2012).

Ao mesmo tempo em que há o crescimento exponencial, não há normatização ou um consenso de uso das redes no âmbito educacional. Empresas, escolas, instituições públicas e privadas lançam suas regulamentações conforme seus interesses. Como se trata um instrumento que pode ter vários usos, educacional, profissional, pessoal, publicitário, entre muitos outros, suas aplicações e alcances acabam sendo analisadas de uma maneira única, o que nem sempre reflete sua potencialidade.

Fato é que a ascensão das redes sociais na internet foi prevista, indicava uma mudança na organização das comunidades on-line, cuja tendência era a organização dessas redes em torno das pessoas e não de grupos de interesses, isto é, redes sociais estruturadas como redes pessoais ou egocêntricas, nas quais o indivíduo é o centro da sua própria comunidade, projeção que vem se consolidando (STALD, 2008). 


\subsection{Sites de redes sociais educacionais}

Como toda breve história de fenômenos maiores, descrever a apropriação dos sites de redes sociais pelo sistema educacional seria sempre algo incompleto. Nesse sentido, optamos por discutir alguns aspectos relacionados ao curso dos fatos e questionamentos atuais sobre como as redes sociais foram dialogando com o cenário educacional.

Atualmente, há muito interesse das escolas e universidades no potencial das mídias para alavancar ou complementar as atividades de educação formal e melhorar os resultados da aprendizagem. Enquanto os esquemas de e-learning estão integrados em muitos contextos educativos, o uso dos sites de redes sociais segue outro caminho, mais polêmico.

De fato, ainda há necessidade de evidências sobre o impacto do uso dos sites de redes sociais na educação formal dos jovens. Nas últimas duas décadas, o aumento de computadores nas escolas foi significativo e, acompanhado pela queda de custos e pelo advento da internet e da Web 2.0, permitiu que os computadores se tornassem uma poderosa ferramenta de comunicação. As salas de aula do mundo industrializado sentiram essa mudança (COLE M; COLE S, 2004) e certamente as escolas têm um papel crucial como ambiente para promoção da inclusão digital preparando seus alunos para o exercício da cidadania em diferentes espaços sociais.

Se por um lado a perspectiva é promissora, avançamos quantitativamente no número de equipamentos, acesso a internet e reconhecimento da importância do seu uso na educação, por outro o Índice de Avanço Tecnológico (IAT), criado para avaliar a disseminação das tecnologias, demonstra que o Brasil está em $43^{\circ}$ lugar ranqueado atrás de países como Panamá, Trinidad e Tobago e Romênia, entre 72 países (LACERDA 
SANTOS, G.; GALÁN, J., 2012). Este índice considera indicadores como capacidade de inovação, difusão das tecnologias mais recentes e antigas e taxa de escolaridade.

O sucesso ou fracasso dos computadores em sala de aula tem relação com a sua forma de apropriação. As mudanças que ocorrem no ambiente de sala de aula dependem muito do seu número, da sua capacidade, como e por que são introduzidos nos diferentes ambientes educacionais. Na década de 1990, alguns estudos apontavam para um conjunto de possibilidades de uso do computador em sala de aula: o computador como tutor, havia uma expectativa de que pudesse desempenhar o papel de um professor em sala de aula, mas até os dias atuais, isso ainda não se concretizou, e talvez não seja esse o caminho; o computador como aluno, para que as crianças aprendessem programação associada a disciplinas específicas a partir dessa experiência; o computador como recurso, relacionado à disponibilização das máquinas e informações abundantes para os alunos, partindo do pressuposto de quanto maior o número de informações, maior a chance de novas aprendizagens; e, por último, o computador como transformador, ou seja, pesquisadores na área do desenvolvimento argumentam que o maior efeito do uso de computadores na sala de aula é reorganizar a experiência educacional intercambiando as interações dos alunos, não apenas com as matérias a serem aprendidas, mas também com o professor, os colegas, a escola como instituição e o mundo (COLE M; COLE S, 2004, apud Crook, 1996). Existem múltiplas formas de aplicação das tecnologias nas escolas que, em última instância, são relacionadas ao acesso à informação em tempo real - o que possibilita uma dinâmica mais contemporânea para o ambiente educacional, à redução da distância entre as pessoas, ampliando, assim, o círculo de interlocução e, finalmente, à livre expressão nas escolas por meio das redes sociais (LACERDA SANTOS; BRAGA, 2012) 
Com o constante debate na mídia, nas escolas e as pesquisas na área sobre a possibilidade de dependência, efeitos adversos e a vulnerabilidade dos adolescentes diante do uso das redes sociais, os pais e até mesmo alguns profissionais da área educação tornam-se cada vez mais cautelosos com seu uso (FALLIS, 2013). Esses aspectos têm sido muito enfatizados e, muitas vezes, servem de justificativa para a não inclusão das tecnologias nas escolas, mas é preciso cautela nesta análise pois o tema pode polarizar os estudos acerca do uso das redes sociais.

Há uma divergência de perspectiva entre pais e filhos. De acordo com o relatório realizado pela USC Annenberg School Center for the Digital Future, em 2009, 69\% das crianças referiam-se à internet e as rede sociais como algo muito importante ou extremamente importante para seus trabalhos escolares; enquanto os pais têm uma visão diferente: $76 \%$ deles acreditam que a internet não tem efeito sobre as notas escolares dos filhos. Navegar na internet para trocar informações relacionadas à escola é provavelmente uma das razões mais aceitáveis atualmente pelas famílias para seu uso (COLLINS, P.; RAHILLY, K.; RICHARDSON, I.; THIRD, 2011)

Outro argumento dos pais e educadores gira em torno da questão atencional. $\mathrm{O}$ pressuposto é de que as novas tecnologias digitais de informação, comunicação e expressão representam um problema para a atenção, processo cognitivo essencial para a aprendizagem. Os adolescentes se confrontam com muitos apelos durante o estudo, como assistir a um vídeo, enviar um e-mail ou compartilhar alguma informação nas redes sociais; diante de tantas solicitações, o risco é que a intenção de saída desapareça. Importante ressaltar que os internautas jovens e adolescentes navegam cada vez menos nos motores de busca e sabem cada vez melhor definir seus interesses na internet e avaliar os documentos localizados. Eles perdem menos tempo e se dispersam menos e são mais objetivos nas redes de relacionamento (BOUBÉE, 2011). Se os estudantes 
estão usando as redes sociais cada vez mais em atividades educacionais, isso é excelente, mas não exime o sistema educacional de ensiná-los a como utilizá-la enquanto objeto de aprendizagem para favorecer a aquisição de conhecimentos. Hoje, a maioria dos alunos que sai do ensino básico não está preparada para isso (ZHU et al., 2011).

Concluindo, a utilização dos sites de redes sociais enquanto sistemas colaborativos, com forte componente social, vem se estabelecendo entre os jovens independentemente da sua aplicação educacional. Vimos que os sites são voláteis, tomam formas variadas, são substituídos, as comunidades migram, mas o uso da ferramenta se consolida cada vez mais. A literatura evidencia que houve uma crença quase ingênua de que as tecnologias iriam transformar as práticas pedagógicas de sala de aula. Como vimos, a tecnologia promove e permite que sejam praticados diferentes tipos de competências e comportamentos, no entanto não promoveu mudanças fundamentais na prática do ensino tradicional.

Estas constatações evidenciam a pertinência do caminho que estamos percorrendo neste estudo, isto é, criar uma rede social para educação incorporada a um contexto onde as estruturas, ferramentas educacionais e conceitos se constituam como uma base para as interações online e, consequentemente, a sua expansão intensifique os processos de aprendizagem.

A Quinta Dimensão é um sistema educacional baseado na construção compartilhada do conhecimento. Das suas bases conceituais emergem três elementos chave para a aprendizagem: a interação social, o uso da tecnologia e o ensino orientado para a autonomia. Este sistema não enfatiza o que aprender, mas como aprender e em que direção devemos seguir. Por um lado, conforme descrito nesta revisão bibliográfica, um dos pontos fundamentais na ecologia da web 2.0 para a educação foi deslocar e 
ampliar o foco de atenção do acesso à informação para o acesso a outras pessoas. Os objetivos deste estudo então se corroboram na medida em que os recursos dos sites de rede sociais aqui descritos podem intensificar o potencial de interação social da 5D. Por outro lado, o desenho destas interações remotas irá apoiar-se em um sistema educacional fundamentado. A capacidade de apoiar, modificar e expandir os vários aspectos da troca de experiência, talvez, se configure como o impacto mais profundo das redes sociais na aprendizagem, ainda que não tenha sido plenamente realizado. 


\section{METODOLOGIA}

Esta investigação foi construída sobre os princípios metodológicos da pesquisaação participativa. A opção por uma abordagem metodológica é fortemente afetada pelo tipo de problema que o pesquisador se dispõe a enfrentar, somado a uma série de outras circunstâncias, como contexto de estudo, apoio logístico, entre outras. Para um estudo dessa natureza, a diferença crucial reside no compromisso do pesquisador em tomar a mudança como parte do ato de investigação. Fundamental para a pesquisa-ação é a ideia de que o mundo social só pode ser entendido ao tentar mudá-lo.

A escolha dessa abordagem deu-se em função do entrelaçamento de uma série de fatores: a harmonia entre a natureza do método e o objetivo maior deste estudo, expandir o sistema educacional 5D por meio da inserção de uma rede social. Escolhemos a pesquisa-ação, sobretudo, porque temos um compromisso de longa data com o desenvolvimento de estratégias e métodos mais eficazes para promover o desenvolvimento social e educacional de jovens com lesão cerebral. Escolhemos a pesquisa-ação, pela relação ativa que existe nessa abordagem entre pesquisadores e pesquisados.

A pesquisa-ação tem uma extensa história em muitos campos da prática social. Em linhas gerais poderia ser definida como um processo democrático preocupado com o desenvolvimento prático do conhecimento alicerçado em uma visão participativa de mundo. Nela reúne-se ação e reflexão, na busca de soluções para as questões ou situações prementes. Apropriado para investigação em configurações similares ao ambiente educacional que explora as perspectivas individuais e coletivas na formação do sujeito, o objetivo de uma pesquisa-ação participativa é unir as pessoas de forma colaborativa para gerar uma mudança social em uma direção desejável (KEMMIS; 
MCTAGGART, 2007). Constituída ao longo do tempo a partir de uma série de áreas de estudo existem fortes elementos da pesquisa-ação na obra de John Dewey, tanto em sua obra filosófica quanto em seus estudos e experiências em educação (OQUIST, 1978). Kurt Lewin trabalhou extensamente na perspectiva da pesquisa-ação nos EUA na década de 1940 e seguiu por um tempo trabalhando a noção de investigação em colaboração com partes interessadas, tinha uma intenção libertadora e o apoio e interesse de uma ampla gama de cientistas sociais (LEWIN, 1946). No Brasil, Paulo Freire desenvolveu e promoveu a abordagem de pesquisa-ação para investigação e modificação do cenário de opressão social (FREIRE, 2007). O que une todas essas tradições de estudo ao sistema educacional 5D é a noção do conhecimento socialmente construído, dentro de um sistema de valores compartilhados pelo grupo, que promove a interação, a troca de experiência e a autonomia individual.

Elementos epistemológicos estão sempre implícitos na discussão sobre métodos de investigação científica, pois irão explorar os diferentes pontos de vista acerca dos efeitos da modificação da realidade no processo de produção do conhecimento. Na pesquisa-ação, a produção de conhecimento, com toda a sua complexidade, deve ser relacionada a contextos históricos e sociais específicos. Portanto, respostas às indagações teóricas devem fazer referência ao desenvolvimento humano e contar com a participação dos grupos investigados para busca de elucidação. Nessa perspectiva, uma questão sobre educação não pode ser entendida como uma indagação lógica abstrata, mas, sobretudo, como uma questão socialmente e historicamente situada. Para a pesquisa-ação, estaria aí a base epistemológica da produção de conhecimento.

A práxis social é o ponto de partida e de chegada para a construção do conhecimento, une a teoria produzida pela inteligência humana ativa, crítica e criativa, com a prática, interações humanas com ambientes naturais e sociais (OQUIST, 1978). 
Esse modo de explanação empregada nas práxis e baseada no conhecimento é dialético. Fundamenta-se em uma série de proposições ontológicas, dentre elas, a noção de que todos os fenômenos estão em constante mudança. O conhecimento seria, então, a compreensão da dinâmica da mudança; e essa mudança não ocorre arbitrariamente. Os processos de transformação social, ao mesmo tempo que dela dependem, também resultam da combinação de fatores externos que condicionam a transformação interna humana.

Ao longo do cotidiano do processo de implantação e adaptação do programa 5D na Rede Sarah, enfrentamos uma série de desafios. Apesar disso, tínhamos contextos Institucionais muito favoráveis. Por um lado, os princípios de abordagem ao paciente na Rede Sarah foram desenhados ao longo dos anos de forma humanizada e com a participação dos maiores interessados, pacientes e família (BRAGA, 2009); e, por outro, encontramos no grupo de pesquisa do Laboratório Ábaco, coordenado pelo professor Dr. Gilberto Lacerda, na Universidade de Brasília um campo aberto de possibilidades de estudo. Não conseguiríamos desenhar um projeto de reabilitação que atendesse as demandas sociais e educacionais mais atuais dos jovens com lesão cerebral, se nos encerrássemos em uma célula estéril, distante de quem vive cotidianamente a situação. Envolver os membros de grupos sociais no processo de investigação é um valor fundamental partilhado por pesquisadores-ação, subjacente à sua capacidade de compreender e abordar as questões em colaboração com suas comunidades.

Trata-se de um procedimento muito bem planejado e pensado enquanto prática social de produção de conhecimentos com impacto direto em ações sociais. A pesquisaação exige o mesmo rigor necessário em qualquer outra abordagem metodológica de natureza científica (LEWIN, 1946). Existe uma espiral de ciclos de estudo 
autorreflexivo que descreve essa metodologia. Como se fossem etapas de um plano geral. Isso inclui: averiguação e planejamento de uma mudança; ação e observação dos processos envolvidos e as consequências da mudança; reflexão sobre processos e implicações; replanejamento; novamente observação e ação; novamente reflexão e assim por diante (TRIPP, 2005). O reconhecimento dessas etapas tem quatro funções: primeiro, deve avaliar a ação, verificando se o que foi alcançado está acima ou abaixo das expectativas; depois, fornecer ao pesquisador a oportunidade de aprender, por exemplo, a possibilidade de ter novos insights a respeito da força e das limitações de certas técnicas de ação; além disso, uma averiguação bem-feita deve servir como base para o planejamento da próxima etapa; e, finalmente, serve como base para modificação e ajuste de todo o plano (LEWIN, 1946). Espera-se que uma gestão social racional continue numa sequência de passos, cada uma composta por esse ciclo de planejamento e ação e por evidências sobre o resultado geral da ação.

Durante a realização deste estudo, tivemos que contar com muita habilidade e apoio para lidar com uma série de eventos. Ao mesmo tempo que implantávamos o programa nas diferentes unidades da Rede Sarah, desenvolvíamos a rede social, lutávamos por afirmá-la como mais uma ferramenta do sistema educacional e, além de tudo isso, buscávamos compreendê-la. Avaliar um projeto dessa natureza, que já dura uma década, foi um desafio complexo e delicado. A dimensão desse projeto evidencia que a problemática abordada, no contexto deste estudo de doutoramento, não surgiu aleatoriamente, mas encadeada e em decorrência de uma situação preexistente e fortemente ancorada em um contexto social e historicamente situado, conforme apontado acima. 


\subsection{Metodologia para criação da rede social}

O plano de ação para a criação da rede social foi composto por três grandes etapas interligadas, cujo processo ocorreu de forma intercalada no tempo.

Na primeira etapa, de 2006 a 2009, que antecede o princípio deste estudo formal, ocorreu o início do processo de implantação do programa 5D nas diferentes unidades da Rede Sarah e as primeiras tentativas de troca de informações e integração compartilhando o livro de dicas entre os grupos situados em Brasília. Em 2009 os alunos, estagiários do programa, passaram a usar uma plataforma educacional, para postarem dúvidas, compartilharem textos, trocarem ideias com os profissionais que supervisionam o programa. A segunda etapa, de 2010 a 2011, quando surgiu a problemática em estudo, consistiu na implantação da primeira tentativa de rede social, o blog 5DLog.

A terceira etapa, já no contexto formal do doutoramento, iniciado em 2012, compreendeu a formatação da problemática de investigação, a concepção, 0 desenvolvimento e a implantação da rede social denominada 5DNet e o levantamento de dados junto aos seus usuários. A Figura 3 exibe a síntese do que foi esse plano, remontando ao início do programa na Rede Sarah, em 2006. 


\section{Plano de ação 5DNet}

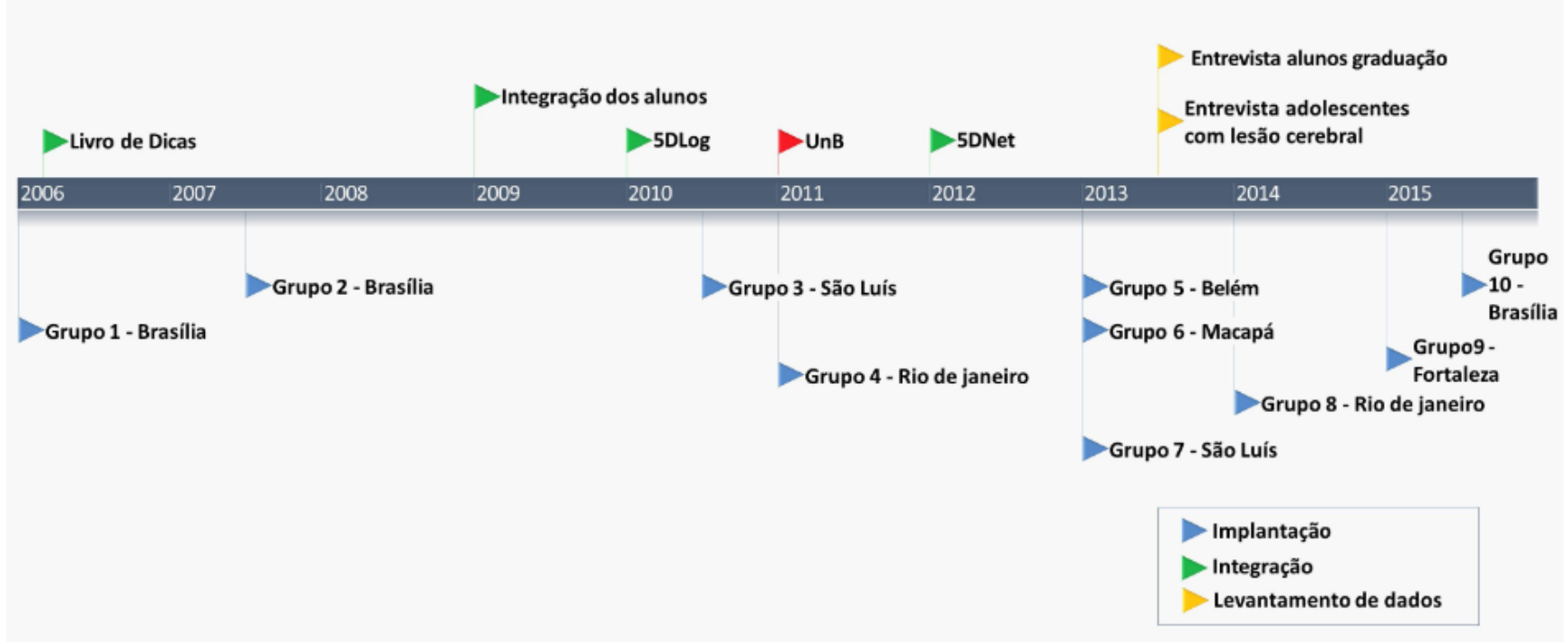

Figura 3 - Plano de ação para criação da Rede Social

Os componentes da primeira e da segunda etapa foram descritos e nos conduziram à elucidação das questões de pesquisa e, consequentemente, à validação da expansão do projeto 5D com a criação de uma rede social.

Para análise de desempenho da rede social 5DNet, objeto deste estudo e criada na terceira etapa do projeto, utilizamos dois parâmetros: a conectividade e a centralidade da 5DNet. Esses dados têm estrutura matricial e suas células representam as medidas de relacionamento entre os indivíduos, foco do nosso interesse. Para tanto utilizamos um software de análise estatística de redes sociais, o UCINET 6.596 for Windows ${ }^{\circledR}$. Para visualização gráfica da rede foi utilizado Visone, Analysis and 
Visualization of Social Networks, ${ }^{8}$ versão 2.6.5®. Printscreens da rede foram utilizados para ilustrar os seus recursos.

Alguns procedimentos foram necessários como apoio à criação, organização e implantação da rede social 5DNet. A organização do ambiente, a grade horária e a rotina garantiram o alinhamento dos programas 5D nas diferentes unidades da Rede Sarah, além disso, foram desenhadas diretrizes iniciais para utilização da rede social em um contexto de reabilitação. Todos os procedimentos serão detalhados a seguir.

\subsubsection{Organização do ambiente e material educacional}

O sistema 5D tem um ambiente organizado para a atividade. Em cada unidade da Rede Sarah há um espaço físico destinado ao projeto. Nesse ambiente há uma série de computadores (entre 10-12 máquinas) que são distribuídos de maneira planejada em forma de ilhas para facilitar o trabalho em grupo; todos os computadores são ligados em rede dentro do mesmo ambiente e entre as diferentes unidades. Cada usuário tem um login de identificação e acesso ao sistema 5D, onde estão indexados todos os games ou outros jogos disponíveis e registradas as atividades realizadas pelo adolescente. Além dos computadores e dos games, o programa foi equipado com um Xbox com Kinect ${ }^{\circledR}$, com um Playstation ${ }^{\circledR}$ e um console de Wii ${ }^{\circledR}$. Junto aos equipamentos eletrônicos mantivemos, ainda, jogos de tabuleiro, revistas em quadrinhos e material para pintura. O acervo dos programas das diferentes unidades da Rede Sarah não se modifica muito;

\footnotetext{
${ }^{8}$ Disponível em: https://visone.info
} 
no entanto, ajustes ao contexto local foram feitos a depender dos interesses e hábitos dos adolescentes do local onde seria implantado. Procuramos selecionar jogos que enfatizassem as diferentes formas de raciocínio, de habilidades sociais e de habilidades para a resolução de problemas. Entre eles, usamos jogos que envolvem cálculo, computação, sequenciamento lógico, análise e priorização de informações. O nosso objetivo é oferecer tantas opções quanto possíveis para o adolescente selecionar uma atividade de interesse e motivação.

\subsubsection{Grade horária}

A grade de horário do programa 5D na Rede Sarah foi organizada estrategicamente de forma que pudéssemos ter a maior malha possível de usuários online. O programa ocorre duas vezes por semana, sempre no horário contrário ao da educação formal, tanto do estagiário quanto do adolescente com lesão cerebral. A carga horária semanal de atividades do estagiário é de 12 horas ( 8 presenciais e 4 remotas) e a do programa para o adolescente em reabilitação é de 5 horas semanais. Em média, cada grupo é formado por 10-12 adolescentes com lesão cerebral e 10-12 estagiários. Na Tabela 2 são apresentados os dias e períodos em que são realizados o programa nas diferentes unidades, por exemplo, nos grupos de terça e quinta à tarde, aconteciam em paralelo seis grupos, estimou-se que 120 sujeitos em potencial (entre adolescentes e estagiários) pudessem acessar a rede social no mesmo período. 
Tabela 2 - Grade de Horários 5D na Rede Sarah de Hospitais

\begin{tabular}{ccccc}
\hline \multirow{2}{*}{ Segunda } & Terça* & Quarta & Quinta & Sexta \\
\hline \multirow{3}{*}{ Manhã } & RIO G1 & & RIO G1 & \\
& MCP G1 & & MCP G1 & \\
& SLZ G1 & & SLZ G1 & \\
\hline \multirow{2}{*}{ Tarde } & BSB G1 & & BSB G1 & \\
& RIO G2 & BSB G2 & RIO G2 & BSB G2 \\
& MCP G2 & BSB G3 & BCP G2 & BSB G3 \\
& BEL G1 & FTZ G2 & SLZ G2 & FTZ G2 \\
& SLZ G2 & & FTZ G1 & \\
\hline
\end{tabular}

Rio-Rio de Janeiro; MCP-Macapá; SLZ- São Luis; BSB- Brasília; BEL-Belem; FTZ- Fortaleza

\subsubsection{Rotinas do programa}

As rotinas de atividades para os grupos nas diferentes unidades foram construídas de forma semelhante. Ajustes contextuais são possíveis e, mais do que isso, importantes e desejáveis, mas estão no âmbito da organização social no próprio grupo e não estão relacionados à macro-organização. Na Tabela3 é apresentada, sumariamente, a rotina do programa 5D nas diferentes unidades, a duração de cada etapa e seus participantes.

Tabela 3 - Rotina de Atividades 5D

\begin{tabular}{l|l|l}
\hline \multicolumn{1}{c}{ Duração da atividade } & \multicolumn{1}{c}{ Estagiários } \\
\hline $30^{*} *$ & Planejamento, organização do & Adolescentes \\
& material, discussão sobre temas \\
& sobre o programa, responder \\
& mensagens enviadas ao mago & \\
\hline $2 \mathrm{~h}^{* *}$ & Interação social no parque de atividades \\
\hline $30^{* * *}$ & Encerramento das atividades em situação espontânea: pais, adolescentes, \\
& estagiários e equipe técnica \\
\hline $1 \mathrm{~h}^{*}$ & Supervisão de atividades \\
\hline$*$ inicio e término estagiários; $* *$ inicio e término adolescentes
\end{tabular}

* inicio e término estagiários; ** inicio e término adolescentes 


\subsubsection{Diretrizes iniciais de uso da rede social no contexto 5D}

As mesmas estratégias de mediação social utilizadas no programa $5 \mathrm{D}$ foram aplicadas para estimular o uso da rede social durante sua implantação. De fato, a nossa intenção era não ter um script predeterminado de utilização da rede, mas permitir que ela fosse gradualmente apropriada pelos usuários do sistema educacional de maneira prazerosa e natural. É claro que no processo de mediação social o estagiário estava atento ao interesse do grupo em dar um sentido e incorporar essa nova ferramenta ao projeto, cientes de que havia desafios, mas também conscientes da importância para os adolescentes em ter um espaço protegido de utilização da rede social. Mas tudo isso deveria acontecer na parceria entre ambos. Trabalhando juntos, ajudando uns aos outros e divertindo-se. Essas eram as diretrizes compartilhadas entre todos os estagiários envolvidos no projeto e discutidas periodicamente nas supervisões do estágio.

\subsection{Metodologia para avaliação do uso da rede social}

Esta etapa do estudo funcionou ao mesmo tempo como avaliação e aprimoramento da rede social, e permitiu a elaboração de uma compreensão ampliada sobre os efeitos dessa experiência, a partir de uma sequência de entrevistas semiestruturadas realizadas com os usuários da 5DNet, adolescentes em reabilitação e estagiários, alunos de graduação em Psicologia e Pedagogia.

O levantamento de dados acerca da rede social implantada foi multicêntrico, conduzido em várias unidades da Rede Sarah simultaneamente. Foram entrevistados 33 adolescentes com lesão cerebral e 34 estagiários das unidades de Brasília, Rio de 
Janeiro e São Luís. Essas unidades foram selecionadas porque compartilhavam, à época, maior tempo de participação e experiência no projeto. Foram entrevistados todos os usuários da rede social que frequentavam o programa, na data da coleta de dados. Em média os adolescentes entrevistados utilizavam a rede social havia um ano e quatro meses - o mais novo participante estava no projeto havia dois meses e o mais experiente, dois anos e sete meses. Todos os adolescentes entrevistados apresentavam razoável expressão verbal, conseguindo entender e responder às solicitações. ${ }^{9}$ O mesmo desnivelamento de experiência caracterizava o grupo. Em média os estagiários tinham sete meses de programa, os mais novos tinham três meses de projeto e os mais experientes um ano e quatro meses. Ao contrário de outros métodos objetivos de investigação, a heterogeneidade do grupo, neste caso, é desejável, pois incorpora os processos de criação e utilização da rede social nos seus diferentes momentos.

\subsubsection{Entrevistas com os adolescentes}

O trabalho de levantamento de dados com os adolescentes seguiu princípios éticos e metodológicos da entrevista semiestruturada (MANZINI, 2004). Todas as entrevistas foram realizadas em um período de duas semanas. A intenção era que essa entrevista fosse um diálogo o mais natural possível, dentro do contexto do projeto. Neste sentido, optamos por que elas fossem realizadas pelos estagiários, mas

\footnotetext{
${ }^{9}$ Os pais foram informados dos nossos objetivos e, caso concordassem, seus filhos eram convidados a participar dessa etapa do estudo. Todos os pais aceitaram a participação. Os responsáveis assinaram o Termo de Consentimento Livre Esclarecido. Os adolescentes só participaram desse diálogo na medida do seu interesse.
} 
supervisionadas por um profissional de reabilitação local. Para o treinamento, os estagiários participaram de uma técnica de dramatização do tipo role playing, de forma que, apesar de terem a vivência com o adolescente com lesão cerebral no cotidiano do programa 5D, pudessem estar mais preparados para explorar as questões envolvidas em situações de levantamento de dados.

Existem definições precisas sobre a entrevista semiestruturada e o seu caráter aberto favorece que o entrevistado responda as perguntas dentro de suas possibilidades individuais, o entrevistador não deve perder de vista o seu foco, sobretudo com sujeitos com lesão cerebral, em função de suas alterações de pensamento. Familiarizados com os adolescentes, os estagiários também foram orientados a apoiar a construção do pensamento, tomando o turno da fala, usando um estilo positivo e ajudando na elaboração de ideias mais complexas ou, ainda, usando técnicas de apoio à elaboração do raciocínio, introduzindo tópicos no diálogo, explicando, mantendo o tema, enfim, apoiando no que fosse necessário.

Considerando-se as questões de estudo, método de investigação e perfil da população entrevistada, optamos por elaborar um roteiro guia como parâmetro para os estagiários, a fim de obter informações sobre as principais áreas de interesse, incluindo o sentido da rede social, a colaboração entre o grupo, conhecimentos e habilidades adquiridos, ação e operação da ferramenta. Nesse roteiro foram apresentadas orientações gerais, possíveis interferências durante a entrevista, procedimento e consignas gerais. ${ }^{10} \mathrm{O}$ roteiro foi revisado e foi verificada a validade das consignas em relação aos objetivos do estudo.

${ }^{10}$ Roteiro de entrevista com os adolescentes: 5DNet 


\subsubsection{Diário de campo dos estagiários}

Conforme descrito no desenvolvimento do projeto de estágio, durante a sua formação os alunos são ensinados a documentar detalhadamente o seu trabalho em diários de campo e a elaborar documentos reflexivos com base em suas notas. São orientados, ainda, a exercitar os textos narrativos e descritivos de suas atividades no programa. Esses arranjos parecem induzir a uma forma única de ensino teórico-prático (COLE, 2006).

Uma vez que todos os alunos já estavam muito habituados a essa forma de documentação, faziam isso após cada dia de atividade, duas vezes por semana, durante o período em que permaneciam no estágio; optamos por utilizá-la como estratégia para

As consignas listadas abaixo irão servir de base para uma entrevista/diálogo com o adolescente. Devem ser gravadas, para posterior transcrição. Explique nosso objetivo, estamos querendo compreender, conhecer, sua opinião, o que ele acha/pensa sobra a 5DNet. Caso o adolescente levante algum tema sobre a 5DNet que não esteja incluído neste roteiro é importante valorizar e explorar o assunto e, depois, retomar a sequência do diálogo com base no roteiro. Alguns adolescentes têm alterações de fala e linguagem. Nessa situação além de gravar, faça anotações sobre o diálogo, para que depois possamos transcrevê-lo.

Durante o diálogo use conectores de pensamento, palavras de ligações ou o que julgar que irá ajudar na troca de ideias entre você e seu entrevistado.

Antes da entrevista, grave os dados cadastrais: seu nome completo (entrevistador); unidade em que faz o estágio; nome da criança completo (entrevistado).

1. Na sua opinião, para que serve a 5DNet?

2. O que você gosta de ver na 5DNet?

3. O que você gosta de fazer na 5DNet?

4. Qual foi a coisa mais interessante que você viu ou fez na 5DNet?

5. Mudaria alguma coisa? 
levantamento de dados com os estagiários acerca da 5DNet. ${ }^{11}$ Nosso interesse era levantar informações que fossem parte do cotidiano, de maneira que o questionário estivesse imerso na sua experiência prática de formação. Para o levantamento de dados com os estagiários elaboramos um roteiro dos domínios investigados. Esse material foi indexado ao site educacional do estágio onde são postadas, regularmente, todas as tarefas e atividades do programa de formação. Todos os questionários foram entregues na mesma data. Os alunos ficaram livres para inserir novos temas que não tivessem sido pensados a princípio, mas que julgassem relevantes. ${ }^{12}$

11 Todos os estagiários foram convidados a participar dessa atividade e esclarecidos dos seus objetivos. Quatro estagiários não permitiram que seu perfil fosse incluído na tabela da amostra, mas autorizaram a utilização de suas entrevistas (diário de campo).

12 Roteiro para registro dos estagiários acerca da 5DNet

As questões ou consignas abaixo são um roteiro para que possamos refletir sobre sua experiência e o sentido da 5DNet. Você pode respondê-las uma a uma ou fazer um relato corrido que contemple os diferentes tópicos. Fique à vontade para fazer referência a qualquer tema que não tenha sido contemplado neste roteiro, mas que tenha relação direta ou indireta com a 5DNet. E que julgue relevante. Caso sinta necessidade, consulte suas notas ou diários de campo.

1. Com que frequência, em que situações e com quais objetivos você usa a 5DNet?

2. Para você, qual a função dessa ferramenta dentro da microcultura 5D?

3. Durante o semestre, você mediou a interação de alguma criança na 5DNet? Relate com uma pequena descrição e reflexão.

4. Relate sua impressão sobre a 5DNet, descrevendo pontos positivos ou restritivos.

5. Pensando na utilização da 5DNet e em como torná-la melhor, deixe suas sugestões/análise. 


\subsection{Procedimento de análise das entrevistas dos adolescentes e diários de campo dos estagiários}

As mesmas etapas e processos foram seguidos para tratamento dos dados de ambos os grupos, tomando a análise de conteúdo como referência (BARDIN, 2011).

$1^{\mathrm{o}} \mathrm{O}$ primeiro trabalho foi organizar o material, transcrever integralmente as entrevistas com os adolescentes gravadas em meio digital. Após a transcrição, dúvidas foram checadas com os estagiários. Os diários de campo dos estagiários já foram entregues em meio digital, em formato de texto.

$2^{\circ}$ Em seguida, foi estabelecido o primeiro contato efetivo com todo os documentos, em conjunto. As entrevistas e os diários de campo foram lidos e relidos exaustivamente, conforme proposto por estudiosos da análise de conteúdo, deixandonos nos invadir por primeiras impressões como uma forma de encontrar orientações preliminares sobre o conjunto do material (BARDIN, 2011). Neste momento, trabalhamos em conjunto com os 67 documentos: 33 entrevistas dos adolescentes com lesão cerebral e 34 diários de campo dos estagiários. Ter trabalhado com o material unificado, em um primeiro momento, permitiu a posterior comparação entre os grupos.

$3^{\circ} \mathrm{Na}$ sequência, passamos a elaborar indicadores com base na frequência e repetição explícita de palavras. Já nessa etapa, utilizamos o software Nvivo Qualitative Analysis Software, ${ }^{13}$ que nos auxiliou na organização e na operacionalização de análises. A unidade de registro selecionada foram palavras-tema. Tomamos bastante cuidado nessa escolha, pois é muito conhecido que uma mesma palavra pode ser preenchida por ter diferentes significados, no entanto, como estávamos tratando da

${ }^{13}$ Nvivo, Qualitative Analysis Software, QRS International Pty ltda. Versão, 2010. 
análise de dados cuja origem era um ambiente muito bem desenhado (projeto 5D), com sujeitos (adolescentes e estagiários) com experiência na atividade e no uso da rede social, julgamos que esse contexto daria o suporte necessário para essa escolha. Além disso, existe um vocabulário previsível dentro do programa, pois são termos e conceitos que fazem parte das bases conceituais do sistema educacional.

$5^{\circ}$ A principal regra de enumeração escolhida foi a frequência. É reconhecido que a importância e a relevância de uma unidade de registro aumentam com a frequência de vezes em que aparece nas narrativas (BARDIN, 2011). Tratamos todo o material como um texto corrido, ou seja, não foi feita análise questão a questão, pois a estrutura dos textos variou muito, nós mesmos deixamos isso em aberto, e eram temas que se sobrepunham. Esse procedimento nos permitiu chegar a três $(n=3)$ diferentes dimensões compostas por treze categorias $(n=13)$ : a dimensão interatividade foi formada por seis categorias $(\mathrm{N}=6)$; a dimensão educação, por cinco categorias $(\mathrm{n}=5)$; e a dimensão função executiva, por três categorias $(n=3)$. Optamos pelo termo “dimensão" porque ele se caracteriza por diferentes aspectos de uma dada circunstância. As dimensões estão interligadas, mas fazem menção a diferentes faces do uso da 5DNet. Uma mesma narrativa pode se repetir em diferentes categorias.

As dimensões interatividade e educação estão muito ligadas ao cotidiano do projeto 5D. A interatividade está relacionada ao processo expressão e socialização mediado pelo computador que permitiu ao grupo ter acesso a todos os participantes dosistema educacional, expandir a interação social e formar novos vínculos, utilizando diferentes recursos para comunicação. Essa dimensão caracteriza-se pela participação ativa dos usuários da 5DNet no ciberespaço e demonstra a apropriação e a imersão da rede social no sistema educacional 5D; a educação configurou-se a partir das bases conceituais educacionais do programa 5DNet aplicadas à rede social 5DNet por seus 
usuários; e a dimensão função executiva, que está associada ao uso de redes sociais no contexto 5D em neurorreabilitação, agrupou um conjunto de processos mentais os quais regulam o desempenho cognitivo, a comunicação e o comportamento social.

As categorias foram agrupadas e descritas em torno de suas propriedades de forma objetiva e sintética (Tabela 4). Nomeamos cada categoria de forma que fosse a mais explicativa possível do seu conteúdo. Essa primeira descrição, que decorre da préanálise de conteúdo, serviu como uma máscara para que pudéssemos analisar detalhadamente cada documento, entrevistas e diários de campo.

Tabela 4 - Descrição das categorias de estudo

\begin{tabular}{|c|c|c|}
\hline Dimensão & Categoria & Descrição \\
\hline \multirow[t]{5}{*}{ Interatividade } & Amigos & $\begin{array}{l}\text { Caracteriza-se pela relação de reciprocidade e trocas de experiências no ambiente virtual, em } \\
\text { torno das diferentes situações vivenciadas no programa 5D e seus artefatos. Esses atores podem } \\
\text { ou não ter ou formar laços de amizade (RECUERO, 2009) }\end{array}$ \\
\hline & Ferramenta & $\begin{array}{l}\text { A ferramenta é um instrumento que se interpõe entre o sujeito e o objeto do seu trabalho, } \\
\text { ampliando as possibilidades de transformação da natureza (OLIVEIRA, 1999) }\end{array}$ \\
\hline & Linguagem multimodal & $\begin{array}{l}\text { São formas de comunicação que integram uma série de recursos gráficos, som, imagem e } \\
\text { animação, associados ou não à linguagem textual. Utilizada para fazer parte, interagir ou } \\
\text { registrar atividades realizadas na 5DNet (SAWAYA, 2003) }\end{array}$ \\
\hline & $\begin{array}{l}\text { Navegar, Postar e } \\
\text { comentar }\end{array}$ & $\begin{array}{l}\text { Caracteriza-se pela navegação ciberespaço. Ao navegar, os internautas vasculham informações, } \\
\text { passam o tempo percorrendo de maneira descontraída as inúmeras postagens da 5DNet, } \\
\text { compartilham mensagens ou reagem postagens (SAWAYA, 2003) }\end{array}$ \\
\hline & Jogos e diversão & $\begin{array}{l}\text { Abrange o conceito de entretenimento interativo prazeroso. São experiências com significado, } \\
\text { fornecem um conjunto de limites dentro de um ambiente seguro para explorar, refletir } \\
\text { experimentar situações novas com autonomia (FRAU-MEIGS, 2006) }\end{array}$ \\
\hline \multirow[t]{5}{*}{ Educação } & Aprendizagem & $\begin{array}{l}\text { Processo pelo qual o comportamento ou desempenho dos adolescentes ou estagiários } \\
\text { modificado como resultado da experiência de utilização da ferramenta 5DNet no contexto } 5 \mathrm{D} \\
\text { (COLE M; COLE S, 2004) }\end{array}$ \\
\hline & Artefato & São instrumentos simbólicos auxiliares do processo psicológico (OLIVEIRA, 1999) \\
\hline & Atividade & $\begin{array}{l}\text { A atividade é uma ação intencional orientada para um objetivo; sua constituição não é fixa } \\
\text { pode mudar de forma dinâmica (COLE, 1998) }\end{array}$ \\
\hline & $\begin{array}{l}\text { Comportamento } \\
\text { colaborativo }\end{array}$ & $\begin{array}{l}\text { Envolve habilidades como capacidade de negociar em grupo, aproximar-se do colega e solicitar } \\
\text { ajuda aos pares. Nessa dinâmica ocorre o deslocamento do foco da cognição individual para o } \\
\text { conhecimento compartilhado e construído através da interação e troca entre o grupo (COLE M, } \\
\text { COLE S, 2004) }\end{array}$ \\
\hline & Mediação social & $\begin{array}{l}\text { Durante a interação social, adolescentes e estagiários têm a oportunidade de construir } \\
\text { pensamentos mais complexos, resolver problemas, alcançar determinadas formas de raciocínio, } \\
\text { às quais não chegar fazer sozinhos, sem a ajuda de um par mais capaz em uma dada habilidade } \\
\text { ou área de conhecimento (COLE, 2006) }\end{array}$ \\
\hline \multirow[t]{3}{*}{ Função executiva } & Autorregulação & $\begin{array}{l}\text { A autorregulação está relacionada capacidade de controlar as emoções e os comportamentos } \\
\text { diante de impulsos internos e de demandas externas, o que favorece a concentração, a } \\
\text { participação de atividades em grupo e o alcance de objetivos (FEENEY; YLVISAKER, 2006) }\end{array}$ \\
\hline & $\begin{array}{l}\text { Pensamento } \\
\text { metacognitivo }\end{array}$ & $\begin{array}{l}\text { Refere-se à capacidade de refletir e refletir sobre os próprios pensamentos, permite avaliar o } \\
\text { grau de dificuldade de um problema e escolher a estratégia para resolvê-lo de maneira flexível } \\
\text { (COLE M; COLE S, 2004) }\end{array}$ \\
\hline & Planejamento & $\begin{array}{l}\text { Trata-se de um curso a ser seguido em função de objetivos definidos previamente. Para isso é } \\
\text { preciso ter em mente o que está acontecendo no presente, o que quer que aconteça no futuro e o } \\
\text { que é necessário para passar de uma etapa a outra (COLE M; COLE S, 2004) }\end{array}$ \\
\hline
\end{tabular}


$6^{\circ}$ Após todo o tratamento do material, procedemos à analise descritiva de frequência das categorias de cada dimensão citada pelos usuários da 5DNet. Foram analisados o número de sujeitos que fizeram referência a uma dada categoria, número de citações da categoria e percentual de citação por categoria; seguida da analise qualitativa das narrativas por grupo de usuários e, por fim, procedemos à comparação das avaliações dos sois grupos de usuários. 


\section{ANÁLISE E DISCUSSÃO DOS DADOS}

Em uma pesquisa-ação, a evolução teórica ocorre durante o próprio processo de investigação e é resultado da constante interação entre a coleta e a análise de dados (OQUIST, 1978). A organização e apresentação dos resultados, a análise e discussão de dados refletem esse processo. Em primeiro lugar, serão apresentados os dados que retratam o curso de criação da rede social 5DNet e, em seguida, a avaliação qualitativa das entrevistas com seus usuários, categorias e dimensões levantadas, fornecendo ao mesmo tempo respostas às questões de estudo, somadas a soluções abrangentes para problemas práticos educacionais.

\subsection{Criação da rede social 5DNet}

O processo de criação e implantação da rede social se deu de modo natural. Natural no que se refere à sua caracterização e necessidade. Foi concebida em decorrência da intenção de comunicação e troca de informações entre grupos de sujeitos (adolescentes com lesão cerebral e estagiários) que compartilhavam interesses comuns, mas não tinham um meio para dividir suas experiências. Esse processo difere do curso descrito na literatura acerca do desenvolvimento dos sites de redes sociais na internet que, muitas vezes, se molda como consequência de intenções de comunicação, e não como causa (STALD, 2008). De maneira geral, sites de redes sociais não são concebidos por seus usuários, são configurados por eles, mas isso é diferente. Por exemplo, conforme descrito no Capítulo 5 uma rede configura-se em mutação e toma a forma que seus usuários imprimem a ela. Com isso, pode se distanciar da concepção 
original. $\mathrm{Na} 5 \mathrm{DNet}$, o processo se dá de forma inversa, ela foi se aproximando gradualmente da intenção inicial, e isso é muito singular.

\subsubsection{De 2006 a 2009}

A integração entre os grupos na 5D começou com o que foi chamado, originalmente, de Livro de Dicas. A princípio, o livro de dicas serviu como um meio mediacional intragrupo, em que adolescentes e alunos de graduação descreviam estratégias de navegação em diferentes jogos. Esse livro, com essa concepção, foi o embrião da rede social. Entre 2007 e 2009, ele passou a ser o elo entre os dois primeiros grupos do projeto em Brasília e o principal mecanismo de troca entre grupos. Consequentemente, os registros no livro e as dicas de jogos se ampliaram, também eram registradas perguntas e propostos desafios, como charadas, de um grupo ao outro.

\subsubsection{De 2010 a 2011}

Em 2010 criamos um blog coletivo, 5DLog. Uma ferramenta mais dinâmica, cuja estrutura permitia atualizações rápidas a partir de acréscimos ou posts. Era organizado de forma cronológica inversa, podendo ser comentado por todos os usuários do projeto. Funcionou como um diário coletivo on-line, combinando texto e imagens. A Figura 4 ilustra o layout dessa página e a indexação do 5DLog ao labirinto, esse blog integrou quatro grupos do projeto (dois grupos em Brasília, um no Rio de janeiro e outro em São Luís), no período de 2010 a 2012. 


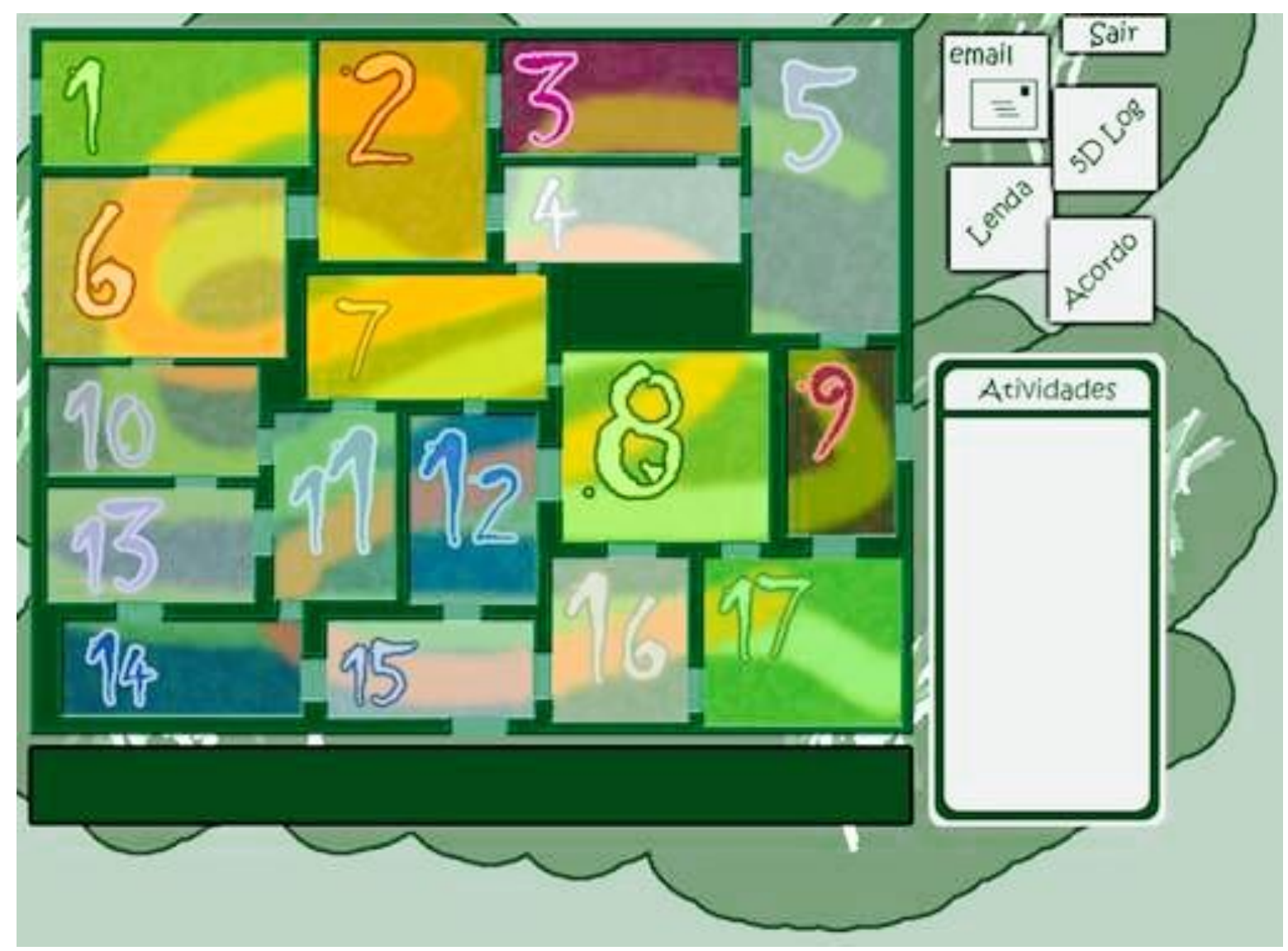

Figura 4 - Layout do Blog 5DLog indexado ao labirinto, 2010

A substituição do texto manuscrito para o meio digital não foi abrupta e se deu de forma compartilhada entre o grupo de adolescentes e os estagiários. No entanto, o conteúdo da comunicação foi relativamente modificado em relação ao Livro de Dicas. Usamos o termo "relativamente" porque essa mudança no conteúdo da comunicação significou uma soma, e não uma substituição. Além das dicas dos jogos e do acúmulo de informações históricas sobre a comunidade 5D, adolescentes e alunos de graduação passaram a se expressar no 5DLog de forma a proporcionar pistas sobre eles mesmos, suas ideias, posições pessoais, feitos pessoais; essa modificação deu uma nova configuração à interação social entre os grupos que não estavam fisicamente próximos e que passaram, então, a se conhecer. 
Historicamente, os web blogs são apropriados como formas de expressão do self e percebidos pelos demais interlocutores como tal. É unicamente por conta dessa percepção que as redes sociais vão emergir nesses espaços (RECUERO, 2009). A Figura 5 ilustra a postagem de uma adolescente de 12 anos, com lesão cerebral adquirida após um atropelamento. A postagem foi redigida e elaborada em cooperação com um par, uma aluna de graduação estagiária. O texto transcrito ilustra a mudança de perspectiva nos registros eletrônicos, além de retratar a natureza reflexiva pessoal sobre um artefato do programa e suas hipóteses. Essa postagem foi denominada teoria de Og@mm. Nela, a adolescente identifica o caráter comunicacional do 5DLog e convoca os colegas a ajudá-la. ${ }^{14}$ Uma segunda postagem toma quase o formato de um diário. Intitulada meus (alguns) jogos (figura 6), foi elaborada por um adolescente de 12 anos, também com lesão cerebral adquirida após um acidente automobilístico aos 10 anos, e expressa muito bem a natureza relacional dessa ferramenta, de sua confiança e intimidade com o grupo. ${ }^{15}$

Além do deslocamento das formas de expressão, a possibilidade de utilização e combinação de elementos visuais e textuais no 5DLog abriu uma nova perspectiva de

\footnotetext{
14 “Ele não comentou muito sobre ele. Uns dias atrás fiquei matutando na minha cachola: como surgiu o misteriosoOg@mm? E criei uma teoria que eu gostaria que vocês comentassem sobre ela bem assim: Alguém misterioso criou este tal Og@mm creio que ele tenha alguma ligação com o Sarah para saber isso ou como ele disse que vive na internet entrou no site www.sarah.com e descobriu o que fazemos. Ele certamente concluiu que a rede de computadores do Sarah estaria bem frágil porque todos estariam descansando, então entrou e desinstalou o muiraquitã e instalou o programaOg@mm."

15 “Eu jogo, porque eu adoro os desafios, josto muito do personagem Wander, Agro colossus. Agoro desenho japones (Anime). O nome do jogo é Shadow of the Colossus. Adoro os jogos do SONY ICO. PS: minha prima gosta muito desse jogo tambem e minha irma tambem."
} 
comunicação entre o grupo. Com a utilização de textos multimodais, que empregam diferentes modalidades de formas linguísticas, abrimos uma nova frente de diálogo no programa. Há um claro deslocamento do contexto da palavra para a combinação palavra e imagem, não apenas como suporte, mas como princípio de expressão.

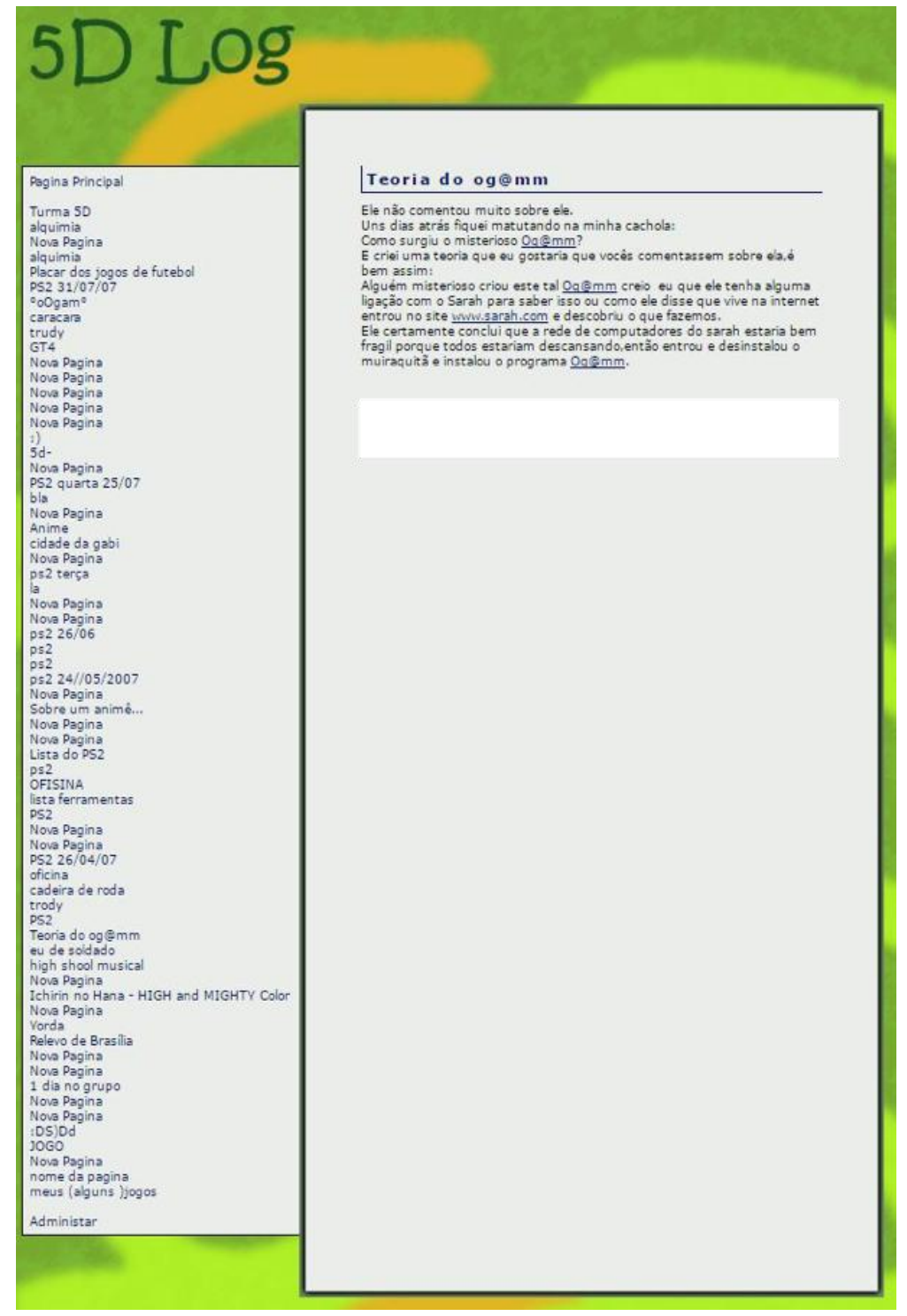

Figura 5 - 5DLog Página de postagens 


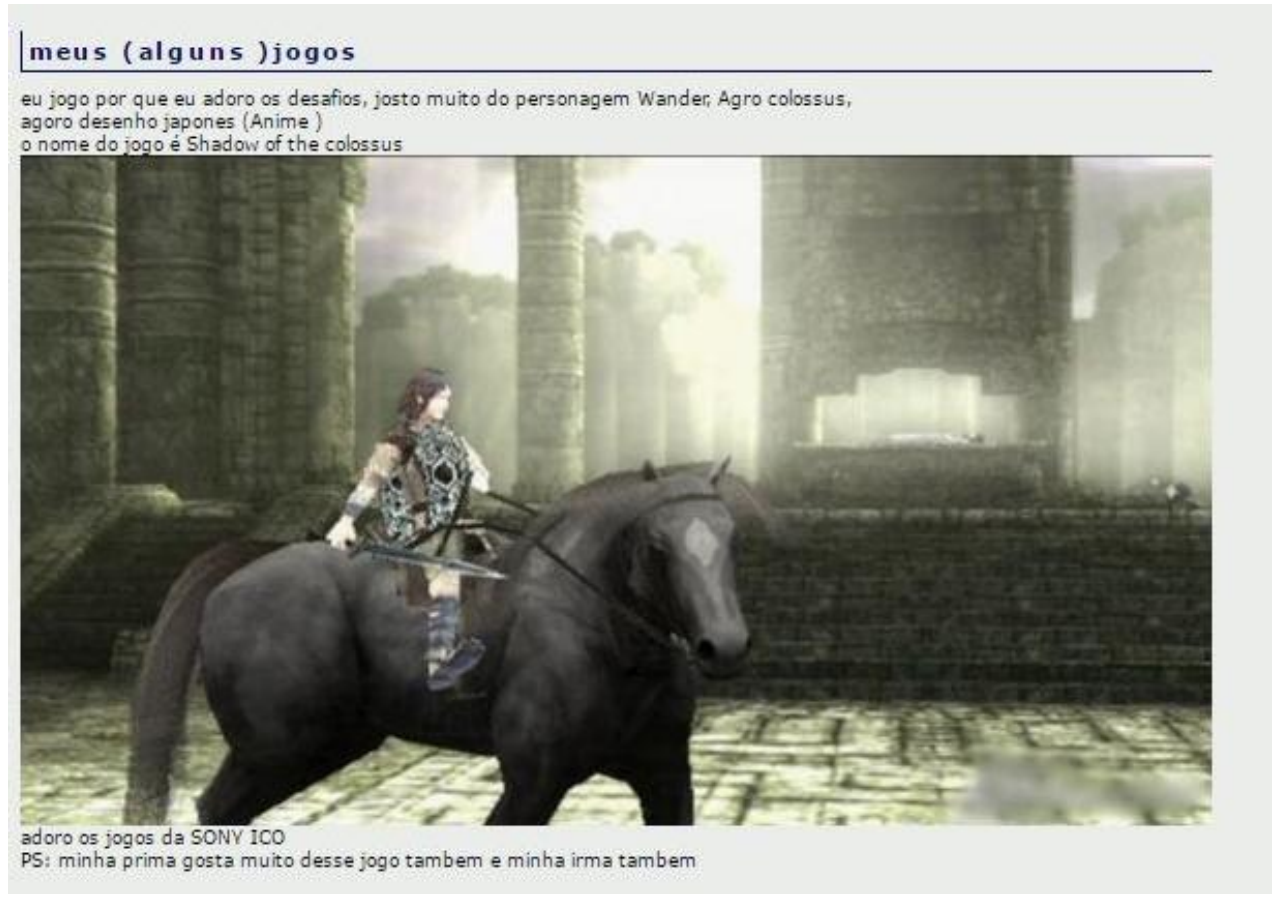

Figura 6 - Meus (alguns) jogos

\subsubsection{A partir de 2012}

Entre 2012 e 2015 evoluímos com a proposta, criamos e aprimoramos a rede social 5DNet. Para desenvolvimento dessa rede, utilizamos o SharePoint, uma plataforma de aplicações web da Microsoft ${ }^{\circledR}$ que possibilita a criação de portais e intranets, gestão de conteúdo, portais colaborativos e publicação de aplicações web (SHARE POINT - OFFICE, 2010). Com esse recurso criamos soluções personalizadas para suprir necessidades específicas do grupo, fazendo com que a colaboração ocorresse de forma mais fluida e intuitiva e, assim, os usuários pudessem ter uma experiência de rede social e seguir as atividades de um colega. Essa rede foi intitulada 5DNet. Ela integrou nove grupos da 5D implantados nas unidades da Rede Sarah e está ativa desde agosto de 2012. Ao longo de sua existência, foram cadastrados 394 usuários na 5DNet, entre eles 190 adolescentes e 204 estudantes de graduação. 
Por ser uma rede experimental educativa e fechada, eliminamos a fase de pedido de amizade, muito comum nos sites de rede social. Na 5Dnet, todos já são amigos. Ela oferece a oportunidade aos adolescentes e estagiários de interagirem com pessoas que vivem situação semelhante, seja no processo de reabilitação ou de formação complementar acadêmica.

Retomamos a Figura 7, apresentada no início deste estudo, que nos forneceu uma visão geral da 5D adaptada à Rede Sarah, só que nesta etapa ela retorna como elemento de comparação à Figura 8, que demonstra esquematicamente a expansão do projeto 5D por meio da criação de uma rede social e seu potencial de conectividade. É importante salientar que todas as ferramentas mediadoras foram mantidas, assim como todos os artefatos educacionais, inclusive a possibilidade de comunicação por e-mail e pela escrita manual através de um mural. O único artefato que deixou de ser usado foi o Livro de Dicas. A 5Dnet não substituiu nada, ela somou. Apoiada em uma sólida estrutura educacional, ela capitalizou uma nova forma de interação social e abriu portas para a expansão do projeto. 
5D - Rede SARAH

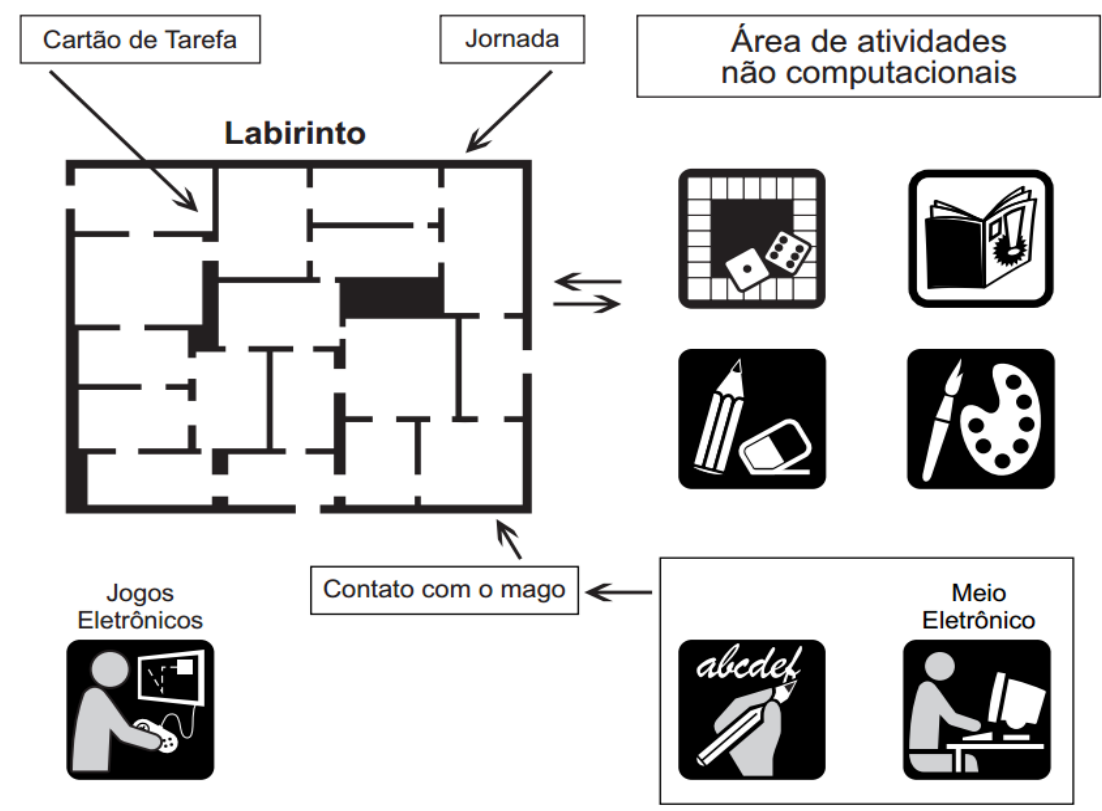

Figura 7 - Visão esquemática do projeto 5D, 2006

\section{D Quinta Dimensão}

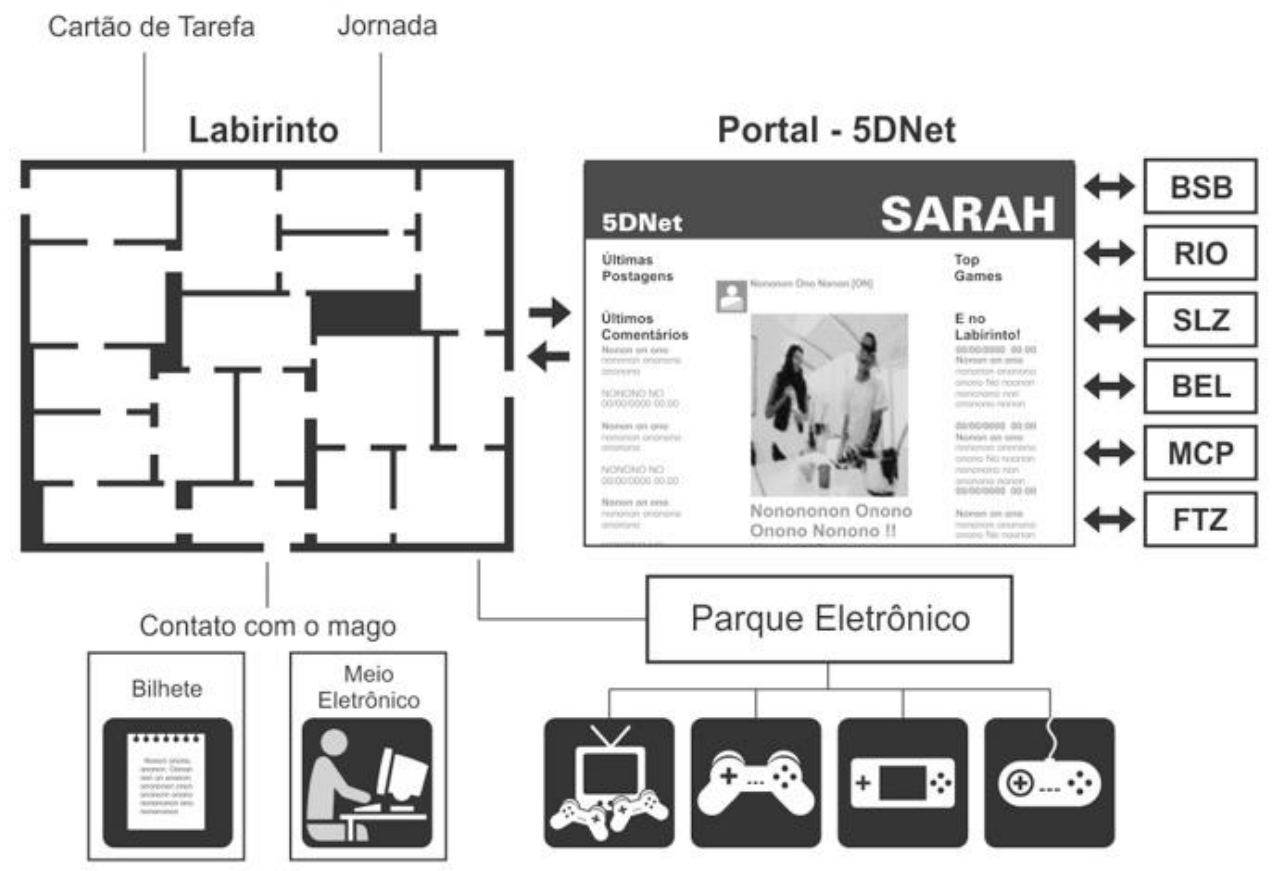

Figura 8 - Visão esquemática da expansão do projeto 5D com a rede social 5DNet, 2015 
Logo abaixo, a Figura 9 retrata o que se tornou o layout do portal 5DNet. Antes de tudo, como em toda rede social, o usuário preenche seus dados e insere uma imagem no seu perfil. A própria rede configura, no perfil pessoal, a unidade da Rede Sarah de onde o usuário participa do projeto. Ao acessar a rede, o usuário tem três possibilidades de atualizar-se acerca das postagens da comunidade 5D: primeiro, no ícone últimas postagens os usuários podem ser informados do que foi postado mais recentemente e por quem, isso permite que fiquem por dentro das novidades do grupo; em seguida, há o campo todos os meus posts, no qual aparece a sua linha tempo; e, por último, a opção últimos comentários, aqui o usuário acessa os comentários mais recentes feitos a qualquer postagem. A informação é sempre colocada em comum. À direita da tela, os usuários têm acesso ao Top game, trata-se do ranking de jogos do programa 5D. Os primeiros da lista são os jogos preferidos pelos adolescentes, os mais disputados e acessados. Em seguida, há o ícone E no Labirinto!, que é atualizado constantemente, sempre que alguém inicia uma atividade no labirinto em qualquer unidade da Rede Sarah. A ideia era que a 5DNet gerasse informações atualizadas sobre os interesses de todos os participantes do projeto $5 \mathrm{D}$, mostrasse que o labirinto fazia parte da jornada de toda a comunidade, despertasse a curiosidade e o interesse de uns pelos outros, mostrasse que compartilhavam um ambiente comum, apesar da distância física. Ligada ao labirinto, que indexa todas as informações sobre as atividades realizadas pelos adolescentes, a 5DNet passa a gerar informações sobre o grupo, além de possibilitar que se comuniquem, postem, comentem ou simplesmente naveguem sem compromisso pela comunidade virtual. Além de todos esses recursos, também é possível anexar imagens, sons e expressar-se por meio de emoticons. 


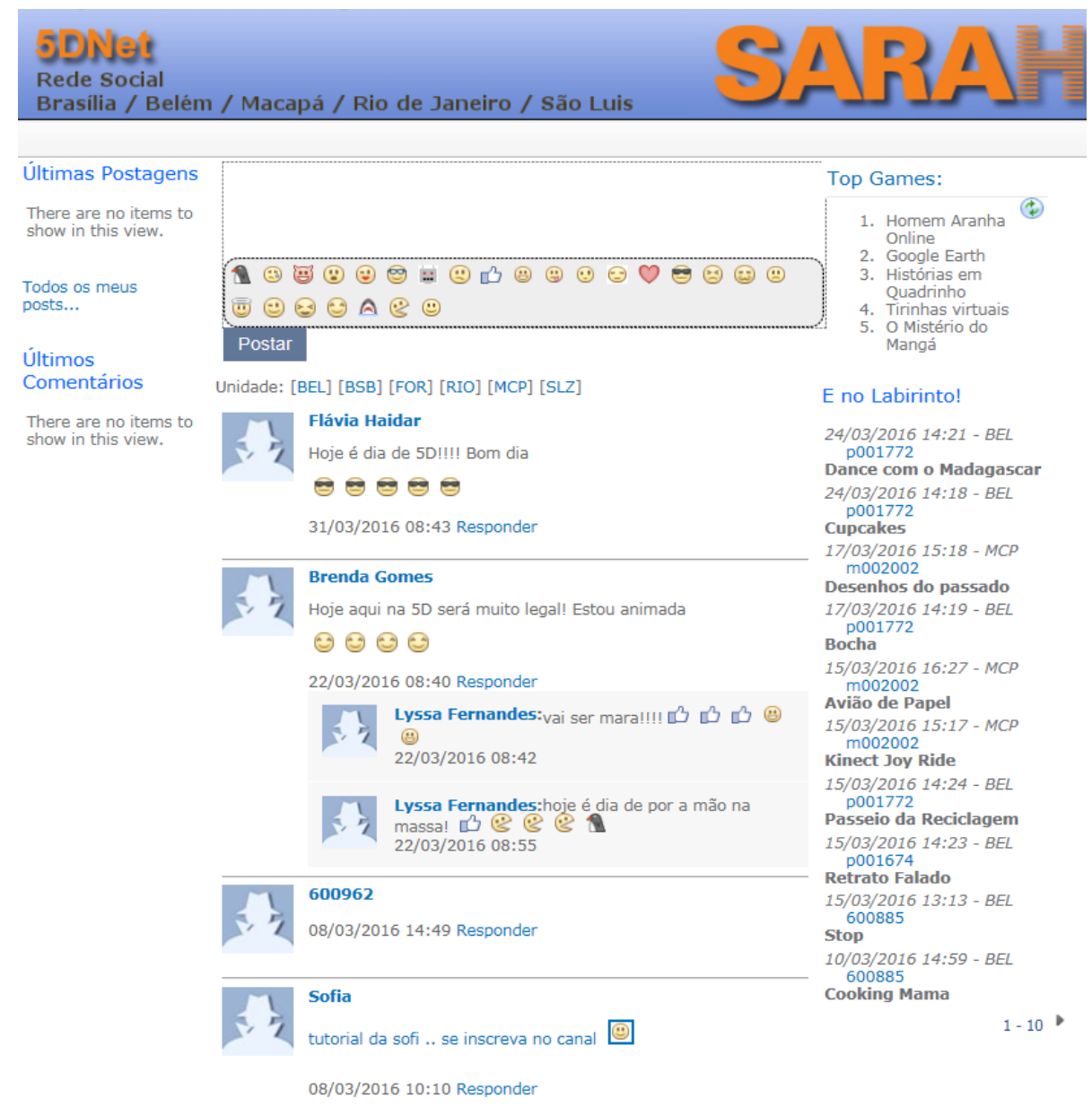

Figura 9 - 5DNet - Página Inicial

\subsubsection{Conectividade da 5DNet}

O fluxo total de interações no período estudado foi de 6.009 conexões. Essas conexões constituíram o ciberespaço, um espaço metafórico estrutural onde não é necessária a presença física do sujeito e o contato face a face para que a comunicação se constitua como fonte de relacionamento. As conexões foram compostas por 2.413 postagens e 3.596 comentários. Postagens sem comentários não foram caracterizadas como conexões, podem até ter sido lidas, terem provocado algum efeito, mas não tínhamos como contabilizá-las. 
Na Figura 10 são apresentadas todas as conexões entre o grupo no período, uma figura simbólica da malha de interações sociais, para além do contato presencial no programa 5D. As unidades da Rede Sarah são representadas por cores e os usuários, por círculos. Os usuários são os nós que moldam a estrutura social virtual. Quanto mais centrais estão os nós, maior a sua penetração na rede social e, provavelmente, maior a sua influência sobre o grupo; quanto mais periféricos estão, menor a interação.

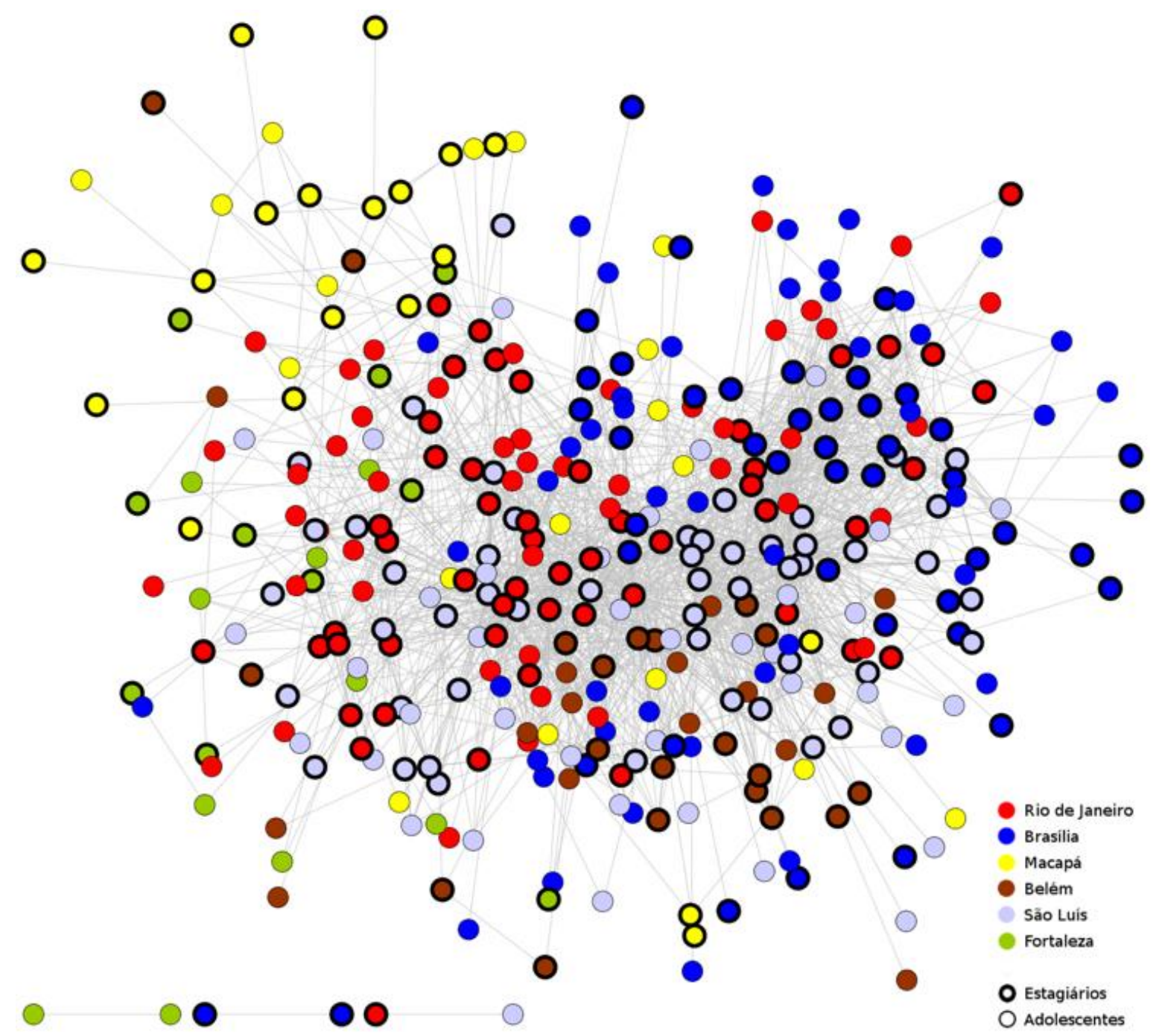

Figura 10 - Conexões da Rede Social 5DNet 
O grupo do Rio de Janeiro tem nós centrais e periféricos e mantém conexões com todos os outros grupos, seus nós estão muito bem distribuídos topograficamente, ou seja, penetram por todo o espaço cibernético; o mesmo ocorre com Brasília, mas com um pequeno recuo em relação a Macapá e Fortaleza e com muitos laços entre seus três grupos; Belém, se distribuiu no espaço inferior direito, mas bem distribuído, de forma que mantém conexões com todas as unidades, exceto com Fortaleza; São Luís se mantém mais à esquerda do espaço de interações e um aspecto chama a atenção, estagiários ocupam locais estratégicos; por fim, Macapá formou uma rede mais situada no espaço, mas alguns nós se distribuem por todo o ambiente, esse grupo está mais conectado entre si.

Tabela 5 - Conexões por unidade

\begin{tabular}{lrrr}
\hline \multicolumn{1}{c}{ Unidade } & Usuários cadastrados & Conexões & $\begin{array}{r}\text { Conexões unidade } \\
(\%)\end{array}$ \\
\hline Belém & 35 & 520 & $8,65 \%$ \\
Brasília & 90 & 1.258 & $20,94 \%$ \\
Fortaleza & 20 & 123 & $2,05 \%$ \\
Macapá & 37 & 194 & $3,23 \%$ \\
Rio de Janeiro & 98 & 2.077 & $34,56 \%$ \\
São Luís & 89 & 1.837 & $30,57 \%$ \\
\hline Total & 369 & 6.009 & $100,00 \%$ \\
\hline
\end{tabular}

Conforme descrito anteriormente, os grupos 5D foram implantados gradualmente ao longo dos anos e o número de grupos nas unidades da Rede Sarah não é equivalente, portanto o número de usuários cadastrados na 5DNet varia conforme a unidade. A Tabela 5 apresenta o número de usuários por unidade, conexões por grupo de usuários e o percentual de conexões em cada unidade. Em Belém, foram cadastrados 35 usuários; em Brasília, 90; em Fortaleza, 20; em Macapá, 37; no Rio de Janeiro, 98; e em São Luís, 89. Ao todo foram 369 usuários cadastrados na 5DNet até o fechamento 
desses dados. Em tese, existe um número máximo de conexões possíveis em todos os nós de uma rede, quanto mais conexões, mais densas a rede e, por sua vez, quanto maior a densidade, maior a coesão entre o grupo. Mas, na prática, tudo isso é muito relativo. $\mathrm{O}$ número de conexões em cada unidade segue claramente outra lógica. Por exemplo, entre Macapá e Belém há uma diferença de quatro usuários, no entanto, Belém possui uma malha de 326 conexões a mais que Macapá; Entre Brasília e Rio de janeiro há uma diferença de cinco usuários, mas o Rio de Janeiro apresenta 819 conexões a mais que Brasília. Apesar dessa diferença percentual, a 5DNet configurou-se como uma rede distribuída na medida em que não há valoração hierárquica desses nós que podem receber e disseminar a informação para quem desejarem.

\subsubsection{Centralidade na 5DNet}

A centralidade é outro parâmetro importante para análise das redes sociais. Frequentemente encontramos nas redes alguns nós com uma posição privilegiada devido à sua relação no espaço virtual. Esse lugar privilegiado geralmente está associado a quanto esse nó é central para a rede social, definido pelo número de ligações incidentes sobre ele, ou seja, a sua popularidade na rede (RECUERO, 2009). A medida da centralidade em uma rede social é dada por graus de conexão, que por sua vez corresponde ao número máximo de ligações que um nó pode ter. Na 5DNet o grau máximo de conexão é igual a 369, o que corresponde ao número de usuários cadastrados, conforme descrito acima.

A configuração das relações na 5DNet se deu de tal forma que não encontramos nós significativamente privilegiados em relação aos demais. De maneira geral, é uma rede igualitária quanto ao aceso e o número de conexões. Os graus de centralidade 
variaram de 1 a 96. Dos 369 usuários, 57,18 \% deles apresentaram grau de centralidade entre 1 e $9 ; 22,49 \%$ entre 10 e 19 graus; $15,71 \%$ entre 20 a 39 graus; e $4 \%$ entre 40 a 99 graus. Isso é muito interessante porque espelha como essa rede foi concebida. Ainda que fosse uma rede educativa, não tínhamos por objetivo privilegiar nós ou fomentar essa posição no espaço cibernético. Ao contrário.

Na Figura 11 são destacados os cinco adolescentes e os cinco alunos de graduação com maior centralidade 5DNet e as tabelas 6 e 7 quantificam essa relação, respectivamente. Apontamos isso como ilustração e para demonstrar mais uma vez a relatividade do poder na rede social. É possível perceber que, sob esse parâmetro, alguns estudantes de graduação do Rio de Janeiro e de São Luís teriam tido um pouco mais de popularidade. O mesmo ocorre em relação aos adolescentes, com a inclusão de um usuário de Belém. Ou seja, a partir da sua topologia e centralidade, podemos afirmar que o controle de 5DNet está distribuído pelos nós e que a sua principal característica é que ninguém se tornou dono da rede. As relações de poder estão muito bem equacionadas e distribuídas. 


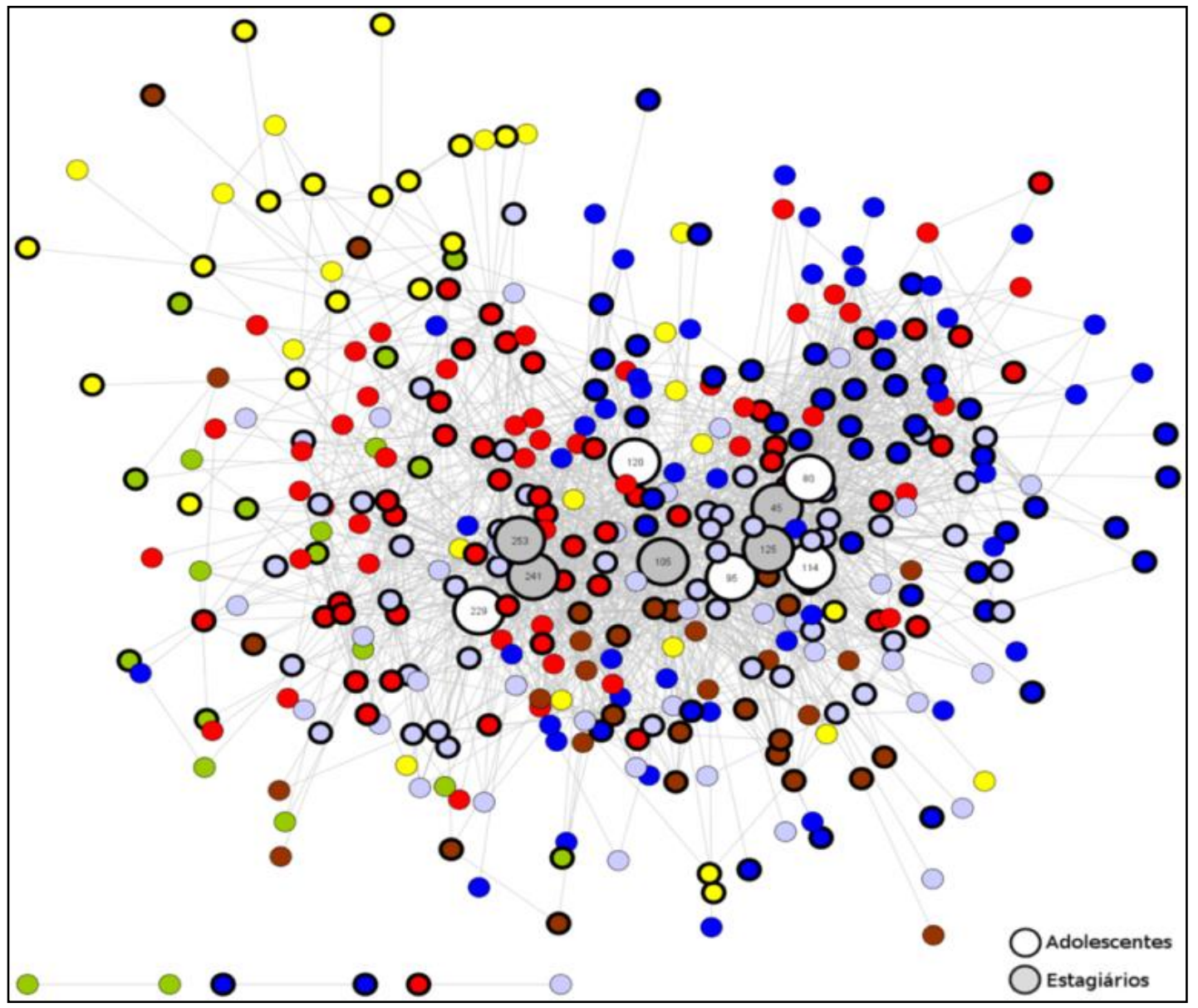

Figura 11 - Centralidade da Rede Social 5DNet

Tabela 6 - Adolescentes com maior grau de centralidade

\begin{tabular}{rlllr}
\hline id & Nome & Unidade & $\begin{array}{r}\text { Grau de } \\
\text { centralidade }\end{array}$ \\
\hline 80 & VLV & RIO & 44 \\
95 & FAMB & BEL & 40 \\
114 & EASS & SLZ & 36 \\
120 & IGPN & RIO & 30 \\
229 & KVBS & SLZ & 27 \\
\hline
\end{tabular}

Tabela 7 - Estagiários com maior grau de centralidade

\begin{tabular}{rlllr}
\hline id & Nome & Unidade & $\begin{array}{r}\text { Grau de } \\
\text { centralidade }\end{array}$ \\
\hline 105 & CSHA & RIO & 96 \\
241 & CBGL & RIO & 64 \\
45 & IESN & SLZ & 64 \\
253 & RCG & RIO & 59 \\
125 & AFS & SLZ & 57 \\
\hline
\end{tabular}




\subsection{Caracterização da amostra para análise da rede social}

Nesta etapa do estudo ocorreu a avaliação da 5DNet à partir dos seus usuários adolescentes com lesão cerebral e estagiários.

\subsubsection{Adolescentes com lesão cerebral}

Participaram da avaliação da 5DNet 33 adolescentes com lesão cerebral em acompanhamento na Rede Sarah, procedentes das três unidades incluídas na pesquisa: Brasília $(\mathrm{n}=22)$, Rio de Janeiro $(\mathrm{n}=8)$ e São Luís $(\mathrm{n}=3)$. Em média, os adolescentes tinham 13 anos de idade $(\mathrm{DP}=2,3)$, todos os participantes usavam a 5DNet regularmente. Alguns haviam usado o 5DLog, e acompanharam a transformação e a construção da nova rede. Dez adolescentes $(n=10)$ tinham diagnóstico de paralisia cerebral $(\mathrm{PC})$ uma menina $(\mathrm{n}=1)$ tinha microcefalia e a maioria do grupo $(\mathrm{n}=22)$ apresentava quadro de lesão cerebral adquirida, destes, a quase totalidade por traumatismo crânio encefálico (TCE), um adolescente com acidente vascular cerebral e outro com encefalite viral (EV).

Todos os adolescentes tinham independência motora, andavam, $43 \%$ com quadro de hemiplegia, 39\% sem qualquer dificuldade de movimento e $18 \%$ com outras alterações. Como a maioria do grupo apresentava TCE, os principais problemas associados à lesão cerebral estavam relacionados às funções do lobo frontal: labilidade do humor, agitação, irritação, impulsividade, planejamento, além de outras alterações, como memória, atenção e linguagem. Todos os adolescentes estavam inseridos na rede de ensino, 32 deles cursavam o ensino fundamental e apenas 1 aluno estava no ensino médio, $79 \%$, entre o $3^{\circ}$ e o $7^{\circ}$ ano. A maioria eram meninos (Tabela 8 ) 
Tabela 8 - Caracterização dos participantes adolescentes

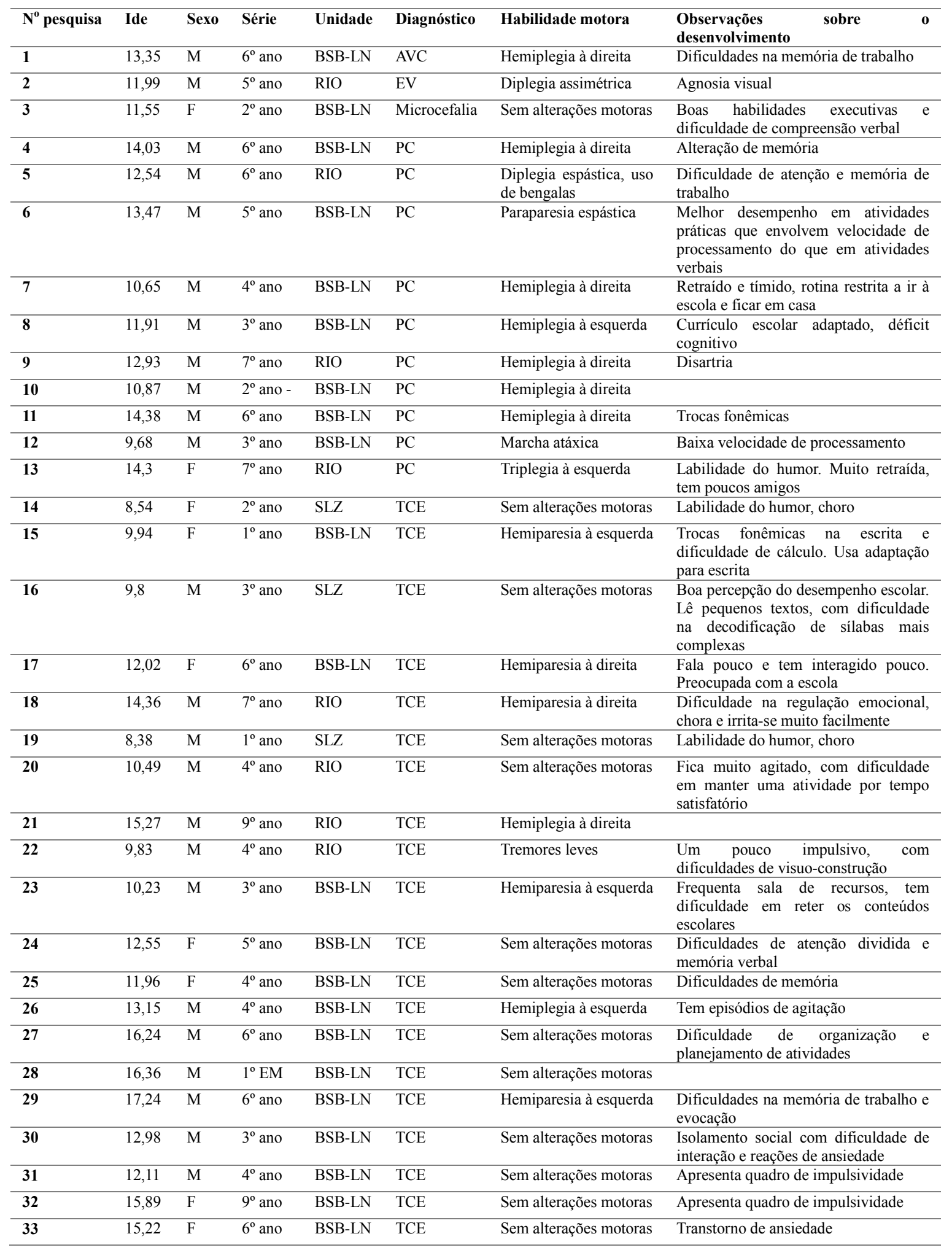




\subsubsection{Estagiários}

No que se refere aos estagiários, foram incluídos no estudo 34 alunos de graduação que estavam envolvidos no programa à época do levantamento de dados. Quatro alunos pediram para não ser identificados na amostra, mas autorizaram a utilização das informações dos seus diários de campo. Os trinta alunos identificados frequentavam as unidades de Brasília $(\mathrm{n}=8)$, Rio de Janeiro $(\mathrm{n}=12)$ ou São Luís $(\mathrm{n}=$ 10). Os estagiários tinham, em média, 20 anos de idade ( $\mathrm{DP}=1,2)$, o aluno mais novo tinha 18 anos e o mais velho, 22 anos de idade. Mais da metade dos estagiários identificados $(60 \%)$ cursava graduação em Psicologia e os demais $(40 \%)$ cursavam Pedagogia. A maioria era do sexo feminino $(n=25)$. Quando ingressaram no projeto, $50 \%$ estava no primeiro semestre da graduação, $37 \%$ no segundo semestre, $6.5 \%$ no terceiro semestre e $6.5 \%$ no quarto semestre (Tabela9).

A diferença de idade entre o grupo de adolescentes e o de estagiários era em média de 7 anos. Podemos dizer que a colaboração entre sujeitos que ainda guardam interesses e papéis sociais comuns e caracterizam-se enquanto duas gerações se configurou exatamente como desejávamos para o estudo. Isso criou um laço de identificação entre o grupo que foi fundamental para o desenho e uso da rede social 5DNet, nos moldes que planejamos. 
Tabela 9 - Caracterização dos participantes estagiários

\begin{tabular}{|c|c|c|c|c|c|}
\hline $\mathrm{N}^{0}$ pesquisa & Sexo & Idade & $\begin{array}{c}\text { Curso } \\
\text { graduação }\end{array}$ & $\begin{array}{c}\text { Semestre } \\
\text { graduação }\end{array}$ & Unidade estágio \\
\hline 1 & $\mathrm{~F}$ & 21,91 & Psicologia & 3 & Brasília \\
\hline 2 & $\mathrm{~F}$ & 22,08 & Psicologia & 1 & Brasília \\
\hline 3 & $\mathrm{~F}$ & 19,95 & Pedagogia & 2 & Brasília \\
\hline 4 & $\mathrm{~F}$ & 19,56 & Psicologia & 1 & Brasília \\
\hline 5 & $\mathrm{~F}$ & 19,56 & Psicologia & 2 & Brasília \\
\hline 6 & $\mathrm{M}$ & 21,86 & Psicologia & 1 & Brasília \\
\hline 7 & $\mathrm{~F}$ & 21,70 & Psicologia & 2 & Brasília \\
\hline 8 & $\mathrm{~F}$ & 18,17 & Psicologia & 1 & Brasília \\
\hline 9 & $\mathrm{~F}$ & 21,52 & Pedagogia & 1 & Rio de Janeiro \\
\hline 10 & $\mathrm{~F}$ & 19,48 & Pedagogia & 1 & Rio de Janeiro \\
\hline 11 & $\mathrm{~F}$ & 19,20 & Pedagogia & 1 & Rio de Janeiro \\
\hline 12 & $\mathrm{~F}$ & 21,74 & Pedagogia & 1 & Rio de Janeiro \\
\hline 13 & $\mathrm{~F}$ & 19,96 & Pedagogia & 1 & Rio de Janeiro \\
\hline 14 & $\mathrm{~F}$ & 19,73 & Pedagogia & 1 & Rio de Janeiro \\
\hline 15 & $\mathrm{M}$ & 21,86 & Psicologia & 1 & Rio de Janeiro \\
\hline 16 & $\mathrm{~F}$ & 18,92 & Pedagogia & 1 & Rio de Janeiro \\
\hline 17 & $\mathrm{~F}$ & 18,79 & Psicologia & 1 & Rio de Janeiro \\
\hline 18 & $\mathrm{~F}$ & 20,28 & Psicologia & 2 & Rio de Janeiro \\
\hline 19 & $\mathrm{~F}$ & 20,36 & Pedagogia & 2 & Rio de Janeiro \\
\hline 20 & $\mathrm{~F}$ & 19,99 & Psicologia & 1 & Rio de Janeiro \\
\hline 21 & $\mathrm{~F}$ & 21,44 & Psicologia & 1 & São Luís \\
\hline 22 & $\mathrm{~F}$ & 19,80 & Pedagogia & 4 & São Luís \\
\hline 23 & $\mathrm{M}$ & 18,49 & Psicologia & 2 & São Luís \\
\hline 24 & $\mathrm{M}$ & 18,67 & Psicologia & 2 & São Luís \\
\hline 25 & $\mathrm{~F}$ & 18,87 & Pedagogia & 2 & São Luís \\
\hline 26 & $\mathrm{M}$ & 19,26 & Psicologia & 2 & São Luís \\
\hline 27 & $\mathrm{~F}$ & 21,13 & Pedagogia & 4 & São Luís \\
\hline 28 & $\mathrm{~F}$ & 21,79 & Psicologia & 2 & São Luís \\
\hline 29 & $\mathrm{~F}$ & 19,24 & Psicologia & 3 & São Luís \\
\hline 30 & $\mathrm{~F}$ & 19,36 & Psicologia & 2 & São Luís \\
\hline
\end{tabular}




\subsection{Avaliação dos usuários da 5DNet adolescentes com lesão cerebral e estagiários}

Nesta etapa serão analisadas e discutidas as avaliações da rede social 5DNet feitas por seus usuários, adolescentes com lesão cerebral e estagiários e comparada as avaliações entre os dois grupos.

Após codificação inicial dos dados, observamos que as dimensões interatividade, educação e função executiva são muito distintas, com diferentes complexidades, e abordam aspectos complementares na utilização da rede social 5DNet. Por exemplo, para fazer referência à categoria navegar (dimensão interatividade), os atores usam uma linguagem coloquial, sintética, própria desse meio de comunicação. No entanto, ao explicar o pensamento metacognitivo (dimensão função executiva), os usuários tecem comentários reflexivos, relacionados a essa forma de raciocínio. Isso não estabelece uma hierarquia entre as dimensões de uso da 5DNet, mas caracteriza uma diferença de complexidade entre elas.

Assim, optamos por analisar as dimensões interatividade, educação e função executiva separadamente, uma vez que a comparação entre elas poderia gerar distorções quanto ao uso da rede social 5DNet em reabilitação. Os resultados serão apresentados conforme as etapas descritas abaixo para cada uma das três $(\mathrm{N}=3)$ dimensões levantadas neste estudo:

1) Estatística descritiva dos adolescentes e estagiários;

2) Análise qualitativa das narrativas dos adolescentes por categoria, seguida da análise qualitativa das narrativas dos estagiários por categoria e da comparação entre ambas; 
Ao final da apresentação e análise de resultados iremos tecer alguns comentários e discussão geral para cada dimensão.

\subsubsection{Dimensão interatividade}

A dimensão interatividade constitui-se a partir de um conjunto de categorias que, de forma direta ou indireta, possibilitam o contato interpessoal e o diálogo a partir da comunicação mediada pelo computador. Na Tabela 10 é apresentado um sumário das categorias que compõem a dimensão interatividade, quantos adolescentes e estagiários fizeram referência a cada categoria e o número total de vezes e percentual de citação.

Tabela 10 - Análise descritiva dimensão interatividade: adolescentes e estagiários

\begin{tabular}{|c|c|c|c|c|c|c|c|}
\hline \multirow[t]{2}{*}{ Dimensão } & \multirow[t]{2}{*}{ Categoria } & \multicolumn{3}{|c|}{ Adolescentes $(n=33)$} & \multicolumn{3}{|c|}{ Estagiários $(\mathrm{n}=34)$} \\
\hline & & Sujeitos* & Citações** & $\%$ & Sujeitos* & Citações** & $\%$ \\
\hline \multirow[t]{5}{*}{ Interatividade } & Amigos & 17 & 30 & 12,24 & 22 & 49 & 11,16 \\
\hline & Ferramenta & 9 & 13 & 5,31 & 25 & 70 & 15,95 \\
\hline & Jogos e diversão & 23 & 64 & 26,12 & 13 & 24 & 5,47 \\
\hline & Linguagem multimodal & 20 & 67 & 27,35 & 31 & 179 & 40,77 \\
\hline & Navegar, postar e comentar & 20 & 71 & 28,98 & 32 & 117 & 26,65 \\
\hline & Total & & 245 & 100 & & 439 & 100 \\
\hline
\end{tabular}

* Sujeitos que fizeram referência a cada categoria; ** número de citações da categoria no grupo.

Para os adolescentes, as categorias mais representativas foram navegar, postar e comentar, seguida de linguagem multimodal e jogos e diversão, considerando tanto o número de sujeitos que fazem referência a elas quanto o número de citações totais pelo grupo e percentuais relativos. Em seguida, a categoria amigos corresponde a 12,24\% do total de citações e a categoria ferramenta, a 5,31\%. Foram as categorias menos representadas pelo grupo nessa dimensão. 
$\mathrm{Na}$ análise dos estagiários, o primeiro aspecto que nos chama a atenção é uma diferença em relação ao volume de citação por dimensão. A linguagem multimodal corresponde a 40,77\% do total de citações, referenciada por 31 sujeitos. Extremamente expressiva no grupo. Em seguida, a categoria navegar, postar e comentar, a qual, apesar de referenciada por um número similar de sujeitos quando comparada à linguagem multimodal, teve uma representação percentual menor no grupo, $26,65 \%$. Na outra ponta, a categoria ferramenta, seguida de amigos e, por último, jogos e diversão são comparativamente menos referenciadas, e por um número menor de sujeitos. Para a análise descritiva da dimensão interatividade, voltaremos à tabela 10 sempre que necessário.

\subsubsection{Categoria amigos}

A categoria amigos foi citada 30 vezes, por 17 adolescentes (Tabela 10). Segundo os adolescentes, a rede de amigos se construiu em torno do interesse em se comunicar e, para eles, a grande questão era estar conectado. A rede é associada à possibilidade de fazer mais amigos. $\mathrm{O}$ fato de utilizarem discurso coloquial e não conhecerem pessoalmente os pares de interação no campo virtual não se constituiu uma questão.

Amigos: narrativas dos adolescentes

(...) E faço amigos... (LGLL; pg 221)

(...) Pra tu ficar conversando com amigos... (JRS; paf 232)

(...) ...fotos dos nossos amigos para falar com eles um monte de palavra..., meus amigos que tão acessando... (PVSM; pg 238)

(...) ...botar, voltar, postar amigo... (MAR; pag 249)

(...) é... pra ti fazer novos amigos na 5DNet tipo de outras 5Ds (FSL; pg 255) 
(...) ...esse negócio de selar amizade (FSL; pg256)

(...) Pra conversar com os amigos do 5D, do DNet... (AFS; pg 257)

(...) Meus amigos e os profissionais... Alguns são legais...(NFG; pg262)

(...) o Rodrigo, Lucas, Talisson, como é que é nome... (NSN; pg 272)

(...) ...fazer amizade com todos...(LS; pg 302)

(...) agora todo mundo é meu amigo...(E; pg 305)

(...) Com os garotos, encontrei novas amizades que mudaram a minha vida de certo jeito...(NFG; pg 263)

(...) ...porque conheço outros adolescentes, que podem me tirar de um mundo e botar para um mundo que seja mais interessante. (ESM; pg 269)

As narrativas dos estagiários acerca dos amigos giraram em torno dos laços que podem surgir na 5DNet e seus desdobramentos para o programa educacional, como aproximar os grupos, formar vínculos de amizade mais duradouros e ampliar a rede de contatos. Foram citadas 49 vezes, por 22 sujeitos do grupo. Os estagiários fazem referência tanto às amizades dos adolescentes quanto às suas próprias amizades nesse ambiente. Apesar das referências serem a amigos virtuais e não presenciais, ainda assim estão presentes nas narrativas algumas funções que as amizades têm para 0 desenvolvimento, entre elas cooperação, informações e companheirismo.

Amigos: narrativas dos estagiários

(...) para que ela me mostrasse e visse os amigos que tinha no seu perfil... (CCNM; pg 175)

(...) fazer amizades... (ACMR; pg 210/ EOL; pg 178; LLCR; pg 214)

(...) aproxima as crianças entre os projetos 5D... (EOL; pg 178)

(...) manter um laço...(IGCCA; pg 180)

(...) criando vínculos mais estáveis por meio de conversas... (NSA; pg 187)

(...) formar vínculos... (RSB; pg 189)

(...) selar a amizade...(BGR; pg 193)

(...) para conhecermos... novas pessoas... (N/I; pg 182)

(...) ligação entre todas as crianças e estudantes do projeto... (IRS; pg 198)

(...) guardar todos os amigos dela e acessá-los quando quiser...(NSA; pg 186)

(...) mesmo ponto liga várias pessoas...(JVSA; pg 201)

(...) ligá-las em um interesse em comum...(JVSA; pg201)) 


\author{
(...) procurar algum amigo... (RLSC; pg 206) \\ (...) achar amigos... (RLSC; pg 206) \\ (...) dividir com os amigos... (LMMAM; pg 203) \\ (...) promover o contato entre as crianças... (DCS; pg 211) \\ (...) contato com as outras 5D... (DCS; pg 211) \\ (...) ampliando o grupo de iguais...(LLCR; pg 214) \\ (...) fortifica os laços entre criança e estudante... (NNR; pg 216)
}

Ao comparar a avaliação entre adolescentes e estagiários, constatamos alguns elementos comuns e outros específicos de cada grupo no que se refere ao significado da categoria amigos. De maneira geral, há uma proporção equilibrada de citações entre os grupos (Tabela 10). Para ambos são interações que se constituem no ciberespaço, movidas por interesses comuns e compartilhados. A capacidade e a força de construir relacionamentos de confiança, apoiados pela identificação do grupo, foi expressiva para ambos. Para os adolescentes, quanto mais amigos melhor, maiores as possibilidades de conexão; já para os estagiários um amigo significa um apoio, um par que desempenha papéis semelhantes e a possibilidade de intensificar a interlocução dos adolescentes. Esse conjunto de significações está relacionado ao papel social que desempenham no programa e as características das duas gerações de usuários.

\title{
8.3.1.2 Categoria ferramenta
}

Para os adolescentes, as ferramentas são instrumentos mediadores da sua atividade, associadas à ação, ao espectro de atividades do programa 5D. Identificam nessa categoria os computadores e a rede social 5DNet. Não há qualquer menção conceitual relacionada à sua educação. São instrumentos que estão à sua disposição no ambiente $5 \mathrm{D}$ e aos quais recorrem sempre que desejam. 
Ferramenta: narrativas dos adolescentes

(...) Eu queria que fosse um labirinto, quer dizer no 5D-NET. (MMC; pg 232)

(...) Faço massinha, jogo videogame, às vezes quando não tem nada eu mexo no computador. (PVSM; pg 237)

(...) E conversar com as pessoas. (LS; pg 299)

(...) tinha computadores, videogame, tinha uns meninos lá que ficavam com a gente. (LV; pg 285)

(...) Jogar no computador. (LS; pg 299)

(...) Os jogos que eu não sabia botar na Internet aí me ensinaram. (LS; pg 300)

A rede social 5DNet foi o único instrumento significado pelos estagiários, nesta categoria. Na perspectiva dos alunos é um instrumento mediador da ação que possibilita aos adolescentes, e também a eles, comunicarem-se, trocarem ideias e conhecerem uns aos outros. Também significam a rede social como um apoio à formação do pensamento. Para eles, o universo virtual é sistêmico e repleto de possibilidades de interação social e aprendizagem.

\section{Ferramenta: narrativas dos estagiários}

(...) faço uso da ferramenta para sugerir atividades com objetivo de orientar à tarde e propor algo novo. (CPM; pg 172)

(...) a ferramenta possibilitou compartilhar produções e atividades interessantes, além de fornecer um espaço para aprender, tirar dúvidas e fazer amizades. (EOL; pg 177)

(...) Acho que esta ferramenta serve para que as crianças possam se conhecer e se comunicar com as outras crianças da Rede Sarah. (N/I; pg 181)

(...) O 5DNet é uma ferramenta que auxilia na metacognição da criança. (BGR; pg 193)

(...) pois tem dificuldade de memória e a ferramenta o auxilia a recordar, já que sempre postamos uma foto da tarde. (FLO; pg 195)

(...) acesso a uma mesma ferramenta onde elas a partir disso podem se conectar e trocar experiências. (JVSA; pg 201)

(...) funciona como uma ferramenta para que a criança interaja com o próprio espaço e os amigos da sua 5D. (JCON; pg 213) 
(...) uma ferramenta que apresenta várias habilidades, tais como: permitir conhecer outras pessoas, surgindo assim uma interação entre as duas partes, tanto entre os estudantes como entre a criança. (NNR; pg 216)

Há uma diferença importante no número de sujeitos que fazem referência à categoria ferramenta entre os grupos e, também, na proporção de citações. Nove $(n=9)$ adolescentes fazem referência a essa categoria, o que representa 5,31\% das citações do grupo, ao passo que 25 estagiários fazem referência a ela, e suas citações representam 15,95\% do total (Tabela 10). Para o adolescente, o instrumento está associado ao computador e à rede social, é um lócus de ação. A narrativa dos estagiários é mais complexa e abrange um espectro maior de conteúdos que associa o uso mediado das ferramentas à educação e interação social.

\subsubsection{Categoria jogos e diversão}

Jogos e diversão é uma categoria muito forte no grupo, ao todo 23 adolescentes fizeram referência a ela, somando um total de 64 citações no grupo (Tabela 10). Para os adolescentes, o entretenimento permeia o uso da 5DNet. Um ponto igualmente importante nesta categoria é a associação que eles fazem entre o labirinto e a rede social implantada. Incluímos os jogos no ranking da rede social como estratégia e isso teve um efeito positivo no sentido da sua apropriação pelo grupo.

Jogos e diversão: narrativa dos adolescentes

(...) Eu acho que os jogos me ajudaram muito naquele raciocínio. Hoje o meu raciocínio está muito bom... (B; pg 309))

(...) O jogo? O de carro, corrida... Futebol, basquete, remo, quase todos... Porque eu tinha coisas para brincar, essas coisas, porque aqui as pessoas tratam “eu” bem, e eu gostava de vir brincar.(LS; pg 299) 
(...) ... não tem lugar melhor do que quando venho aqui para o Sarah, eles são muito engraçados, apesar de serem meninos iguais ao Rodrigo, a gente se diverte muito. Não é? Porque você vai para escola todo muito é careta e não cumprimenta... (MB; pg 315)

(...)... brincar em conjunto... É, jogo... os outros jogos também... se divertir com os outros... (HPB; pg 254)

(...) Eu queria mudar que a gente podia colocar, sabe o facebook? Como um jogo. (MMC; pg 232)

(...) ...tudo foi muito divertido, aprendi muitas coisas. (LV; pg 285)

(...) O 5DNet? A gente entra e escolhe o que a gente pode brincar de jogo. (MS; pg 259)

Apesar de ter sido pouco citada pelos estagiários, apenas 13 sujeitos fizeram referência a jogos e diversão, em um total de 24 referências no grupo (Tabela 10). Ainda assim, suas narrativas evidenciam quanto os jogos foram ressignificados no contexto 5D, um jogo pode ser parte do lazer, mas é um recurso para aprendizagem incorporado em todo o sistema educacional, é uma base para interação de muito interesse dos adolescentes.

Jogos e diversão: narrativa dos estagiários

(...) Um dia que me marcou foi quando eu passei a tarde inteira fazendo uma montagem de fotos a respeito do tema de um jogo de memória que joguei com uma das nossas meninas, a Cecília. Escolhemos várias imagens que a faziam lembrar de viagens que ela ou a mãe havia feito e em seguida nós postamos no 5DNet. (LMMAM; pg 203)

(...) pode pensar sobre o que fez, se foi bom ou ruim, com quem estava e da forma como jogou (se criou novas regras ou não). Diante disso, pode dar dicas, dizer onde se pode encontrar essa atividade no labirinto, quais materiais usou ou até mesmo em que vídeo game se joga. (BGR; pg 193)

Proporcionalmente, a categoria jogos e diversão é mais citada pelos adolescentes 26,12\%, do que pelos estagiários 5,47\% (Tabela 10). Para os adolescentes, divertir-se, jogar e aprender compõem o seu repertório de aprendizagem e estão intimamente ligados aos artefatos e ferramentas do programa. Essa força nos jogos e no divertimento também traduz a óptica de uma geração. Já os estagiários, ao mesmo tempo que são parte da geração internet e navegam muito bem nos recursos tecnológicos, dividem o 
foco com a reflexão acerca das relações entre a aprendizagem e o universo dos games e do entretenimento.

\subsubsection{Categoria linguagem multimodal}

A linguagem multimodal correspondeu a 67 de um total de 245 citações dos adolescentes (Tabela 10). Ao fazer referência ao uso de imagens, som e vídeo, relacionam esses recursos à comunicação com seus pares no projeto 5D. Identificam nesses recursos a possibilidade de expressão que não seria possível apenas com o uso do texto, em função das suas dificuldades de escrita. Não se trata da substituição da linguagem textual, mas da sua possibilidade de expansão que transcende a modalidade escrita.

Linguagem multimodal: adolescentes

(...) Quando colocam fotos... acho legal, porque eu não escrevo mesmo... quanto mais... vídeo assim, charadas, também, fotos, melhor. (JRS; pg 236)

(...) quando a gente faz atividade, a gente tira foto ou então filma, eu gosto de postar lá para os outros verem. (FSL; pg 255)

(...) $\{$ Qual foi a coisa mais legal que você viu ou você fez no 5DNet?\} Postar foto... uma que num quadro, aí eu botei no meu 5DNet. (MAR; pg 248)

(...) postar coisas dos famosos, vídeos e muitas coisas interessantes, por isso eu estou usando mais. (TNM; pg 236)

(...) Para postar fotos... Para mostrar todas as fotos que teve... Fotos dos amigos... mandar fotos para o $\mathrm{Og} @ \mathrm{~mm} . .$. foto da pescaria e do basquete \{fazendo referência às atividades vivenciadas no projeto A Ah! É, também gosto de assistir música... Ficar vendo vídeo sem graça. (GHBC; pg 248)

(...) Coloco minhas fotos e meus vídeos. (DLCM; pg 240)

Para os estagiários, a linguagem multimodal é a categoria mais expressiva do grupo, correspondeu a 179 das citações dos grupos, em um total de 439 (Tabela 10). Constituiu-se como parâmetro do programa entre as diferentes unidades da Rede Sarah. 
Nessa perspectiva, os estagiários usam imagem, vídeos, som e animação e todas as formas de registro para se atualizarem, entenderem o que está acontecendo nas outras unidades, terem referências, equalizarem o programa e relembrarem o que aconteceu nos encontros anteriores. Além disso, quando os estagiários fazem referência ao uso da linguagem multimodal pelo adolescente, isso acontece pela perspectiva da interação social, sem a tarefa linear de ensinar, mas movidos pela possibilidade de descoberta coletiva de outras formas de comunicação entre o grupo.

\section{Linguagem multimodal: narrativas dos estagiários}

(...) fazer algumas postagens de fotos de interações, olhar as postagens de algumas crianças e estudantes de outros módulos, ver um pouco do que eles fazem, ter ideias para atividades, conhecer um pouco do ritmo das outras unidades... (PHMD; pg 217)

(...) Se alguém faz algo interessante na unidade do Rio, por exemplo, podemos ver as fotos... tentar fazer algo parecido em Brasília. (MOSR; pg 184)

(...) Ou até mesmo quando começa a tarde com a criança, sugiro que olhe para ver o que as outras crianças estão fazendo e os comentários das fotos. (IRS; pg 197)

(...) o Léo foi abrindo cada página, clicando nas fotos dos perfis dos amigos e, uma vez ou outra, quando tinha uma foto de alguma atividade que ela gostava abria a foto para vermos...; ela sugeriu que olhássemos as fotos tiradas e, como gostou muito, ela mesma deu a ideia de colocarmos no 5DNet...(CCNM; pg 175)

(...) Disse que queria ver uma foto dela com os estudantes antigos. Mostrei a pasta que tinha e ela foi em seguida clicando em algumas para escolher a que gostava mais. Ela gostou da foto em que estávamos fazendo o Suco Cremoso. (TDRG; pg 219)

(...) ela abriu alguns arquivos... ia mostrando as fotos das pessoas que haviam comentado. Eu lia para ela os comentários, perguntava se ela já havia respondido e a incentivava a responder. (NSA; pg 185)

(...) Depois, ela ficou clicando nas fotos de pessoas conhecidas e fazia o nome dela em Libras... (NSA; pg 186)

(...) A Emmanuele entrou na 5DNet, mas não quis postar... apenas vascular fotos antigas de outros módulos do qual ela participou... (JACON; pg 214)

Um dos principais eixos da dimensão interatividade, tanto para os adolescentes com lesão cerebral quanto para os estagiários foi a utilização da linguagem multimodal; 
31 estagiários fizeram referência a este tema, enquanto entre os adolescentes este percentual foi igual 20 sujeitos (Tabela 10). Recursos como pictogramas, imagens, desenhos gráficos e dispositivos sonoros são muito utilizados em reabilitação para expandir as formas de comunicação de sujeitos com dificuldades de fala e alterações de escrita. Utilizar esses recursos como uma linguagem suplementar, e constituinte das formas de expressão compartilhadas por toda uma comunidade nas redes sociais, traz uma nova perspectiva, amplamente inclusiva, sobretudo por se tratar de um ambiente tão contemporâneo.

Para os estagiários, há outra perspectiva. Na sua formação acompanharam as reflexões e a realização da implantação da rede social. Essa ferramenta era mais do que esperada por eles, sabiam da importância de comunicarem-se com seus pares nas outras unidades. Esse conhecimento em rede faz parte da geração que hoje tem 20 anos, e os membros dessa geração nos dizem de que forma isso é relevante; para eles, imagens, textos, som e vídeos são parâmetros para aprendizagem.

\subsubsection{Categoria navegar, postar e comentar}

Navegar, postar e comentar são ações que levam à interação nas redes sociais. Para os adolescentes, o significado dessa categoria se sobrepõe ao da linguagem multimodal, a linguagem preferida pelo grupo para comunicação na rede social. É a principal categoria nesta dimensão, com 71 citações de um total de 245 (Tabela 10). As narrativas sobre postagem e comentários são permeadas pela expectativa de interação relacionada ao cotidiano de atividades do projeto. Navegar é passear pela 5DNet, se mover de uma página a outra, acessar links, retornar. Para referir-se às navegações, os adolescentes usam termos como "ver", "mexer", "olhar". Essas narrativas indicam que 
sobre uma estrutura educacional bem fundamentada, a navegação silenciosa pode, sim, ser incorporada como outro nível de interação social no processo de aprendizagem.

\section{Postar e comentar: narrativas dos adolescentes}

(...) Tipo... quando a gente faz atividade, a gente tira foto ou então filma, eu gosto de postar lá para os outros verem. Aí dá ideia lá, se gostou, se não gostou... eu vejo o que botaram pras outras pessoas e às vezes eu dou ideia para as outras pessoas. Boto... escrevo um negócio no... na 5D de outra pessoa. (FSL; pg 255)

(...) Eu entro nos meus amigos e olho... (JRS; pg 233)

(...) para mexer mesmo... (DMC; pg 223)

(...) ver as coisas... (DMC; pg 224)

(...) quando não tem nada eu mexo... (PVSM; pg 237)

(...) eu gosto de ver as mensagens, meus amigos que tão acessando. Só... (FBS; pg 244)

(...) É acho que é ver o que as outras pessoas estão fazendo... (HPB; pg 254/ AISM; pg 191)

(...) Pra conversar com os amigos do 5D, do 5DNet. \{Lá no 5DNet? E você faz isso?\} De vez em quando. \{O que você gosta de ver lá no 5DNet?\} Os comentários que as outras pessoas colocam lá... É, comentários... Sei lá. Ver os comentários, postar foto... Escrever mensagem... Escrever mensagem pro senhorOg@amm. (AFS; pg 257)

(...) Vendo o que botaram pra mim, eu vejo o que botaram pras outras pessoas... (FSL; pg 256)

(...) porque eu acho que... quanto mais mexer na 5DNet... (FSL; pg 256)

(...) eu acho legal entrar no 5DNet, ver os desafios... (AFS; pg 258)

(...) É legal, eu olho as fotos das outras pessoas... (ESM; pg 269)

(...) para ver fotos. (CLFSS; pg 270)

(...) Sim. Eu estou usando mais o 5D porque tem muitas coisas legais para fazer, tem como mandar recados, postar coisas dos famosos, vídeos e muitas coisas interessantes, por isso eu estou usando mais. (TNM; pg 236)

A terceira categoria com maior expressão na dimensão interatividade dos estagiários foi navegar, postar e comentar, foram 117 citações de um total de 439 (Tabela 10). Essa categoria surge sempre como uma atividade conjunta de adolescenteestagiário. Assim como a linguagem multimodal, essa categoria significou um parâmetro para os estagiários entre os programas. Para eles, havia uma incongruência em saber que existiam outras pessoas que viviam situações semelhantes, mas que não tinham como se conectar. A rede social entrou nesse espaço, o lugar já existia. Além 
disso, essa categoria também se desenhou em torno da possibilidade de aprofundamento de laços sociais e identificação com pares, a sensação de pertencer a um grupo, poder compartilhar suas descobertas e atividades realizadas, criando novos sentidos para as interações.

Navegar, postar e comentar: narrativas dos estagiários

(...) quando postamos a música feita por nós dois no meu perfil é uma forma de afirmação do Léo como componente desse grupo... (CPM; pg 173)

(...) Neste semestre, publiquei uma imagem de um trailer de um filme, o que levou outras adolescentes a procurarem mais sobre este. Também publiquei um jogo interessante, que levou crianças do projeto de quarta e sexta a verificarem o jogo e experimentarem. O que não foi uma mediação específica, mas um auxílio nas mediações de outros estudantes. (N/I; pg 182)

(...) Foi abrindo cada página, clicando nas fotos dos perfis dos amigos e, uma vez ou outra, quando tinha uma foto de alguma atividade que ela gostou abria a foto para vermos. (CCNM; pg 175)

(...) Se alguém faz algo interessante na unidade do Rio, por exemplo, podemos ver as fotos e comentários e tentar fazer algo parecido em Brasília. (MOSR; pg 184)

(...) Algumas crianças gostam de entrar apenas para "passear" por alguns perfis e ler algumas postagens.

(JMFS; pg 200)

(...) Usamos geralmente com o objetivo de ver as postagens dos estudantes das outras 5D e para estimular que as crianças também façam suas próprias postagens. (JFLR; pg 212)

(...) Serve também para que elas conheçam novas atividades ao observar o que outras crianças postaram ou mesmo se inspirem para realizar alguma atividade e para trocarmos experiências. (N/I; pg 181)

Navegar e postar e comentar caminham em paralelo para todos os usuários da 5DNet, são ações envolvidas nesse mergulho interativo e sem elas não há conexão. A proporção do tema entre os grupos é próxima, corresponde a 28,98\% das citações dos adolescentes e $26,65 \%$ dos estagiários. Além disso, compartilham o significado da categoria, há uma expectativa coletiva dos sujeitos no próprio grupo, saber o que fazem, ver o que comentaram, mostrar o que fizeram. Claro, o papel social que cada grupo desempenha medeia essas narrativas. Mais uma vez, o estagiário compartilha sua fala com os interesses e as necessidades dos adolescentes. 


\subsubsection{Dimensão educação}

O contexto onde foi implantada a rede social 5DNet, os meios disponíveis para a atividade e a organização social do projeto 5D formaram a dimensão educação que, em última análise, é a base conceitual do programa, significada por seus usuários adolescentes com lesão cerebral e pelos alunos de graduação. Na Tabela 11, apresentamos a síntese das categorias que compõem a dimensão educação, seguida dos adolescentes e estagiários que fizeram referência a cada categoria, número de citações e percentual por categoria. O tema mediação social corresponde a 35,98\% das citações dos adolescentes, seguido de comportamento colaborativo, que representa $27,44 \%$ do total; juntos, são as duas categorias mais representativas para o grupo. Nas categorias artefato e aprendizagem, o percentual de citações é de $16,46 \%$ e 13,41\%, respectivamente. Por último, com menor representação no grupo, a categoria atividade soma apenas $6,71 \%$ das citações.

Para os estagiários, as categorias mais citadas foram atividade e mediação social, que representam $35,78 \%$ e $31,63 \%$ respectivamente; juntas, constituem fundamentos conceituais do sistema educacional 5D. Em seguida, o comportamento colaborativo representa $17,25 \%$ das citações, tema também relacionado às bases educacionais do programa. A categoria artefato, apesar de poucos sujeitos terem feito referência a ela $(\mathrm{n}=17)$, representa $12,14 \%$ das citações. Por último, a categoria aprendizagem, como resultado da experiência de uso da 5DNet, foi pouco referenciada pelos estagiários (3,19\%). Na análise abaixo, a Tabela 11 será retomada sempre que necessário. 
Tabela 11 - Análise descritiva dimensão educação: adolescentes e estagiários

\begin{tabular}{llcccccc}
\hline \multirow{2}{*}{ Dimensão } & \multirow{2}{*}{ Categoria } & \multicolumn{3}{c}{ Adolescentes $(\mathrm{n}=33)$} & \multicolumn{3}{c}{ Estagiários $(\mathrm{n}=34)$} \\
\cline { 2 - 7 } & & Sujeitos* & Citações** & $\%$ & Sujeitos* & Citações** & $\%$ \\
\hline Educação & Aprendizagem & 11 & 22 & 13,41 & 9 & 10 & 3,19 \\
& Artefato & 16 & 27 & 16,46 & 17 & 38 & 12,14 \\
& Atividade & 3 & 11 & 6,71 & 28 & 112 & 35,78 \\
& Comportamento colaborativo & 15 & 45 & 27,44 & 25 & 54 & 17,25 \\
& Mediação social & 22 & 59 & 35,98 & 32 & 99 & 31,63 \\
\hline \multicolumn{2}{c}{ Total } & & 164 & 100,00 & & 313 & 100,00 \\
\hline
\end{tabular}

* Sujeitos que fizeram referência a cada categoria; ** número de citações da categoria no grupo.

\subsubsection{Categoria aprendizagem}

$\mathrm{Na}$ categoria aprendizagem, os adolescentes narram os resultados da sua experiência na 5DNet, essa categoria foi citada por 11 sujeitos, 22 vezes (Tabela 11). Associam qualitativamente a aprendizagem à categoria jogos e diversão. Como vimos até o momento, eles tendem a apresentar uma perspectiva unificada, sistêmica, de todos os recursos educacionais. Ao significarem a aprendizagem não foi diferente, mas, ainda assim, alguns adolescentes fizeram referência explicita à rede social, como mediadora ou lócus de registro da sua aprendizagem, que os levará a um melhor desempenho na escola e na vida pessoal. Ou seja, generalizam e fazem referência à transferência do conhecimento adquirido para outros contextos. Associam a aprendizagem a jogos e diversão.

Aprendizagem: narrativas dos adolescentes

(...) ... Serve para melhorar o nosso, humm, hummm... a nossa inteligência...; colocar as minhas experiências... (DCM; pg.224)

(...) $\mathrm{O}$ que eu estou melhorando... O quanto eu já melhorei... Ver vocês e o grupo inteiro aqui do Sarah, vocês todos tão me ajudando, eu consigo agora lembrar tudo da matéria que eu estudei no colégio... (NFG; pg. 262) 
(...) Ah, a ter mais respeito com as pessoas... (NSN; pg.274)

(...) Eu aprendi a não fazer mais isso, a trabalhar em grupo... A respeitar as diferenças de cada um...(NFG; pg.277)

(...) aprendi a compartilhar com os amigos, ajudar os amigos e só... ajudar o próximo e compartilhar...(LV; pg.285)

(...) Quando eu entrei, acho que a partir disso, eu comecei a falar mais, sem ter medo de falar, assim, se falar besteira, foi, é isso; coisa que eu aprendi, eu acho, a falar... (GCB; pg.289)

(...) Eu aprendi que quando alguém quer jogar, você pergunta para ela se ela gostaria de jogar com você ou não para fazer uma parceria a ela.(R; pg.296)

(...) Acho que foi a experiência que eles passaram para mim que mostra que eu tenho que estudar, agora, principalmente. Também tem altas situações que você vê que eu necessito, tá entendendo?... (GCB; pg.292)

(...) Os jogos que eu não sabia botar na Internet aí me ensinaram... Botar a Internet no jogo..., usar a Internet, ver os jogos na Internet, ler umas palavras novas, que a gente já viu. \{Tem alguma coisa mais?\} Fazer amizade com todos...(LS; pg.300)

(...) você aprende mais, vai aprender mais na escola... (E; pg.306)

(...) Eu acho que me ajudou muito, tanto no colégio, eu tô bem melhor no colégio, acho que agora eu tô conseguindo... não é bem mais inteligente, não vou usar isso, eu não sou burra, claro, sou inteligente, tudo bem, eu tô pegando as coisas mais rápido, tô me organizando bem, hoje eu tô ótima... tô boa, não, ótima, mas tô boa... dá para viver...(B; pg.307)

(...) Porque eu mudei muito e acho que cresci muito aqui. Imagine só se eu não tivesse a oportunidade, eu não seria quem sou hoje.(MB;pg.316)

A categoria aprendizagem foi citada 10 vezes, por 9 sujeitos (Tabela 11). Os estagiários relacionam a aprendizagem com interação social, ferramentas mediacionais e fazem referência à 5DNet. Mencionam a aprendizagem dos adolescentes, a sua própria aprendizagem ou, ainda, o processo compartilhado entre ambos, com ênfase mais em processo do que em resultados.

\section{Aprendizagem: narrativas dos estagiários}

(...) Isso fez a Érika se aproximar mais do computador, usá-lo mais e também, em certa medida, a leitura e a escrita. (ACB; pg 134)

(...) acredito que a minha motivação e interesse se deu de forma crescente, pois, aos poucos, consegui entender a funcionalidade para o desenvolvimento da criança e da microcultura. (FLO; pg 196) 
(...) fortifica os laços entre criança e estudante, pois possibilita a socialização da criança e possibilita interações com todos no blog, capacitando e contribuindo para o seu processo de socialização e o seu desenvolvimento. (NNR; pg 216)

(...) ferramenta possibilitou compartilhar produções e atividades interessantes, além de fornecer um espaço para aprender, tirar dúvidas e fazer amizades, desenvolvendo assim, a metacognição e o desenvolvimento real, não só das crianças, mas dos estudantes também. (EOL; pg 177)

Observa-se uma diferença de proporção de citações entre os grupos acerca da categoria aprendizagem, para os adolescentes ela representa $13,41 \%$ e para os estagiários, 3,19\% das citações (Tabela 11). Assim, as especificidades entre os grupos estão mais relacionadas à perspectiva do papel social que cada um desempenha no programa, do que ao significado da categoria.

\subsubsection{Categoria artefato}

O sistema educacional 5D é composto por um vasto conjunto de artefatos que constitui parte da cultura do programa e atua como mediador das atividades do projeto. Dezesseis adolescentes $(n=16)$ fizeram 27 citações à categoria (Tabela 11). Os artefatos são citados, a partir da ação mediadora, como fazer e experimentar. O labirinto foi o artefato mais citado nas narrativas, seguido dos jogos. Por último, os adolescentes fazem referência ao mago, que pode ser acessado através dos computadores, é lembrado como um apoio remoto para suas decisões.

\section{Artefato: adolescentes}

(...) no Labirinto tinha algumas atividades que eu gostava e não. Às vezes tinha umas que eu não gostava e aí eu ficava mudando de sala. Tinha uma que eu ficava dois, três dias lá, aí até quando o labirinto fícou chato e aí deu uma ideia para o Og@MM para procurar mais jogos. (E; pg 303)

(...) porque antes as atividades eram só labirinto. (E; pg 305)

(...) \{Você procurava alguém e as pessoas faziam o quê?\} ... a dica. (B; pg 308)

(...) \{Você sabe que a 5DNet não é um labirinto, né?\} Aham, eu já sei desde o primário. (FWSS; pg 226) 
(...) Faço massinha, jogo videogame, às vezes quando não tem nada eu mexo no computador, brinco de tudo. (PVSM, 237)

(...) e quando foi experimentar \{fazendo referência ao labirinto\} tinha uns jogos bons. (E; pg 305)

A categoria artefato foi citada 38 vezes por 17 estagiários (Tabela 11). O principal tema das narrativas foi a relação entre o labirinto e a 5DNet. Os estagiários usam vários termos, como: proximidade, diálogo, aproximação, conexão e link para referirem-se a mecanismos de conexão entre os artefatos do programa e a rede social. Historicamente, o labirinto tem a função de organização da atividade no sistema 5D, evita que os adolescentes gravitem sobre o mesmo tema e tentem alcançar diferentes níveis de envolvimento, mesmo que isso traga dificuldades e imponha novos desafios. Ao relatar a conexão entre labirinto e 5DNet, os adolescentes apresentam um caminho para incorporar e significar essa ferramenta no sistema educacional.

\section{Artefato: narrativas dos estagiários}

(...) No entanto, eu acredito que neste momento, ela exerce a mesma função do Hints book do projeto original. Lá as crianças postam imagens ou comentários de atividades que fizeram, compartilhando sugestões com os outros. (CPM; pg 173)

(...) Dessa forma, as crianças já sabem que em algum momento vão acessar o labirinto e que ele tem coisas a oferecer que os divertem. (CCNM; pg 176)

(...) a ferramenta auxiliar durante a interação, fazendo parte dos desafios e propondo tarefas que estão relacionadas diretamente com o labirinto. (FLO; pg 195)

(...) Como as crianças gostam muito de jogar, talvez o 5DNet pudesse remeter alguns jogos, talvez algum que possa ser jogado entre elas, cada um acessando um site. Isso poderia ser uma atividade sugerida em alguma sala do labirinto. (CCNM; pg 177)

(...) eu e um menino aqui do Rio estávamos em uma sala onde tem desafios sobre conhecer o mundo. Enquanto estávamos em uma atividade de tabuleiro, misturada com o globo e conhecendo vários lugares diferentes que tive a luz de postarmos no blog alguma coisa sobre esses lugares. (ALSH; pg 190)

(...) atividades feitas no labirinto e postadas no 5DNet, criando um assunto comum entre as crianças da 5D mesmo que sejam de outro estado. (IRS; pg 197)

(...) pode dar dicas, dizer onde se pode encontrar essa atividade no labirinto, quais materiais usou ou até mesmo em que vídeo game se joga (BGR; pg 193) 
(...) Algumas vezes o próprio labirinto nos direciona no desafio a postar sobre a atividade que fizemos como: dicas sobre o jogo, fotos ou vídeos, links ou até mesmo um pequeno texto, como se fosse mais uma “etapa” do desafio que escolhemos. (RLSC; pg 205)

(...) é alimentado pelo labirinto e tem várias funções na microcultura que podem ser exploradas de diversas maneiras pela mediação. (SBR; pg 208)

(...) sua proximidade com o Labirinto, pois ao mesmo tempo em que a criança desenvolve a atividade de se comunicar com o Og@MM, facilita o login no blog. (JFLR; pg 2013)

A diferença de citação da categoria artefato não é expressiva entre os grupos. Para os adolescentes, ela representa $16,46 \%$ das citações, ao passo que para os estagiários representa 12,14\% (Tabela 11). Os adolescentes associam a categoria artefato à ação; já os estagiários procuram estabelecer conexões entre os artefatos do programa, sobretudo o labirinto, e a 5DNet, incorporando-a ao sistema educacional. Levantam uma série de proposições e análises sobre a questão.

\subsubsection{Categoria atividade}

Referenciada por poucos sujeitos do grupo $(n=3)$ e com um número de citação também pequeno em relação às outras categorias da dimensão, $\mathrm{n}=11$ (Tabela 11), para esses adolescentes o significado de atividade foi associado à aprendizagem ativa, que tem um movimento em direção a algo. Identificam na atividade o processo de construção de conhecimento. Ao engajarem-se em uma atividade (que necessariamente está ligada à prática), poderiam registrá-la, filmá-la e compartilhá-la na rede social com seus colegas de grupo.

Atividade: narrativas dos adolescentes

(...)às vezes quando eu fazia atividade, eu demorava muito para saber como é que era a atividade. (E; pg 303)

(...) fazer atividades para poder lembrar de coisas que eu não consigo de jeito nenhum. (NFG; pg 262) 
(...) tipo quando a gente faz atividade a gente tira foto ou então filma, eu gosto de postar lá para os outros verem. (FSL; pg 255)

(...) quando eu entrei aqui tinha um monte de atividades, atividades que eu não tinha feito, que eu nunca tinha conhecido, muitas... (E; pg 306)

(...) às vezes quando fico animado, eu faço isso, converso com as pessoas de uma atividade. (E; pg 306)

(...) no Labirinto tinha algumas atividades que eu gostava e não. Às vezes tinha umas que eu não gostava e aí eu ficava mudando de sala. Tinha uma que eu ficava dois, três dias lá. (E; pg 303)

(...) eu já conseguia escolher uma atividade... porque quando eu entrei não tinha muito interesse... porque quando eu entrei, ficava vendo, achava os nomes ruins, e quando foi experimentar tinha uns jogos bons. (E; pg 305)

A categoria atividade foi a mais citada pelos estagiários na dimensão educação ( $\mathrm{n}=112$ ) e pela quase totalidade de sujeitos do grupo (Tabela 11). Para os estagiários, a categoria atividade foi representada pela interação sujeito, ação e objeto. Ao mesmo tempo que é um motor, um motivo para práxis, é também o seu resultado. Nesse contexto, a 5DNet foi identificada pelos estagiários como mediadora das interações sociais que fomenta e favorece a realização de diferentes atividades.

\section{Atividade: narrativa dos estagiários}

(...) Mas também para crianças, como a Érika, se sentirem incluídas na 5D e estimuladas a realizar outras atividades que não as que elas normalmente realizam. (ACB; pg 170)

(...) Comunicação entre os participantes da 5D, dividir experiências e mostrar as atividades realizadas na 5D. (ACB; pg 170)

(...) mostrar novas atividades para as crianças; aumentar a autoestima das crianças através dos comentários nos posts feitos por elas. (ACB; pg 170)

(...) Lá as crianças postam imagens ou comentários de atividades que fizeram, compartilhando sugestões com os outros. Eu mesma gosto de postar sugestões de atividades no 5DNet. (COM; pg 173)

(...) Acredito que a função seja enriquecer as atividades e as interações. (CCNM; pg 175)

(...) Bem, acredito que a ferramenta tem muito a acrescentar para as atividades. (CCNM; pg 176)

(...) A 5DNet acaba se tornando um facilitador para as mediações através das atividades postadas no blog. (EOL; pg 177)

(...) Acho bom que as crianças tenham acesso a outras atividades e possam deixar suas impressões, compartilhar o que fizeram e ter um contato com outras crianças e estudantes. (IGCCA; pg 180)

(...) inspirem para realizar alguma atividade e para trocarmos experiências. (N/I; PG 181) 
(...) Enquanto estávamos em uma atividade de tabuleiro, misturada com o globo e conhecendo vários lugares diferentes que tive a luz de postarmos no blog alguma coisa sobre esses lugares. (ASLH; pg 190)

A diferença proporcional de citação da categoria entre os adolescentes $(6,71 \%)$ e os estagiários (35,78\%) é relevante (Tabela 11). Nas suas narrativas, esses adolescentes aprofundaram-se e associam atividade e aprendizagem. Por outro lado, é uma categoria amplamente representativa dos estagiários, que exploram a ação, a tecnologia e a interação social como componentes constitutivos da atividade, a qual é movida pelos interesses dos adolescentes.

\subsubsection{Categoria comportamento colaborativo}

A categoria comportamento colaborativo foi citada por 15 adolescentes, 45 vezes, a segunda categoria mais citada na dimensão educação (Tabela 11). Para eles, a colaboração intensifica a interação e a comunicação com seus pares; permite que tomem decisões conjuntas e fortalece o sentimento de coletividade baseado nos resultados do trabalho em grupo. Nas suas narrativas, alguns elementos do sujeito individual partem do trabalho em grupo, como dar opinião, concordar ou não, aceitar ou não, e ouvir o outro.

Comportamento colaborativo: narrativas dos adolescentes

(...) Deram um monte de dicas no meu blog e eu decidi que era bom e... ahn... fiz uma assembleia para decidirmos isso todo mundo junto... e decidimos que vai ser um show de talento... (FSL; pg 255)

(...) brincar em conjunto... (HPB; pg 254)

(...) aprender... com os outros... (HPB; pg 254)

(...) mas amigo é legal porque você pode dividir as coisas... (NSN; pg 273)

(...) sempre quando alguém precisa de mim eu "tô" ajudando mas é como sempre, "tipo" algumas pessoas precisam de mim e aí eu ajudo, normal, do mesmo jeito que eu era lá sou com todo mundo... (LV; pg 288) (...) era assim, às vezes eu pedia ajuda para elas e, às vezes, elas me pediam ajuda...(NSN; pg 273) 
(...) eu aprendi a não fazer mais isso, a trabalhar em grupo (NFG; pg 277)

(...) porque "tipo", lá era assim... todo mundo podia dar uma sugestão e aí às vezes eu dava, alguém dava, de jogar o vídeo game aí tipo o Og@mm jogava com a gente; - e o que vai ser agora? - a gente ainda vai decidir; (E; pg 303)

(...) a compartilhar com os amigos, ajudar os amigos e só... (LV; pg 285)

(...) não, só isso mesmo, de ajudar o próximo e compartilhar...(LV; pg 288)

(...) a turma dá um monte de sugestão, mas às vezes não pode concordar. (MB; pg 316)

Os estudantes ocupam um papel central na interação com os adolescentes, ocupam uma posição entre a equipe técnica de reabilitação e os adolescentes. A orientação é de que procurem não ensinar, mas aprender em conjunto. Ao fazerem referência ao comportamento colaborativo, os estagiários são parceiros de aprendizagem dos adolescentes, flexibilizam seus papéis no processo de comunicação e trabalham no sentido da construção coletiva. Em alguns momentos, a 5DNet é constituinte desse processo de construção conjunta, seus recursos são identificados como um apoio à colaboração.

Atividade colaborativa: narrativas dos estagiários

(...) compartilhar produções e atividades interessantes, além de fornecer um espaço para aprender, tirar dúvidas. (EOL; pg 177)

(...) trocarmos experiências. (N/I; pg 181)

(...) há uma troca de experiências e conhecimento que vai de encontro das atividades realizadas nas outras unidades, fortalecendo o conceito de rede. (FLO; pg 195)

(...) comunicação entre os participantes da 5D, dividir experiências. (ACB; pg 170)

(...) Compartilhando... atividades que fizeram e gostaram, interagem uns com os outros através dos comentários dos posts. (AISM; pg 191)

(...) compartilhar o que quiserem e poder se comunicar com as crianças dos outros estados que vivenciam o mesmo espaço, podendo assim existir uma troca de experiências. (JVSA; pg 200)

(...) se expressar através das postagens e se identificar com as postagens dos outros integrantes das 5D.

(TRSM; pg 218) 
O significado da categoria comportamento colaborativo tem muitos aspectos em comum entre os usuários da 5DNet. Para eles, a base da colaboração é o trabalho em grupo, co-construído nas interações sociais e em direção a objetivos compartilhados. O número proporcional de citações é um pouco maior e mais concentrado em menos sujeitos entre adolescentes, 27,44\%, do que entre os estagiários, 17,25\% (Tabela 11). O que se diferencia entre os grupos é a perspectiva na interação colaborativa que é mediada pelo papel social.

\subsubsection{Categoria mediação social}

O significado de mediação social que se construiu entre os adolescentes é muito objetivo e os conecta a seus pares como apoio para novas aprendizagens. Foi a categoria mais citada pelos adolescentes na dimensão educação $(n=59)$, por 22 sujeitos (Tabela 11). Identificam na diferença de conhecimento e no diálogo a base do processo de aprendizagem escolar, pessoal e de forma lúdica. Esta categoria e análise se sobrepõem à categoria amigos, da dimensão interatividade, e comportamento colaborativo.

\section{Mediação social: adolescentes}

(...) tipo, quando eu precisava de ajuda em inglês, eu perguntava para elas, já que eram formadas e me ajudavam em inglês. (R; pg 296)

(...) O Adriano, que ele já se formou em matemática só que ele não gostou para outro, ele se lembrou um pouco da matemática, ele me ajudou na matemática... (R; pg 296)

(...) Acho que foi conversando com os estagiários... para tirar dúvidas. Ele sabia mais da matéria que eu estava com dificuldade, que era matemática e ele me ajudava a tarde toda a estudar matemática e deu certo... a partir que eu entrei na 5D, acho que continuei o mesmo, mas, tipo que nem na escola, eu tenho uma dúvida, eu falo com o professor, e isso eu não falava antes. (GCB; pg 289)

(...) Aprendi a jogar também com a Fernanda e com um "bocado" de gente lá. (LV; pg 285) 
Em suas narrativas, os estagiários conectaram a categoria mediação social às diferentes categorias da dimensão interatividade, sobretudo amigos, linguagem multimodal, navegar, postar e comentar, todas ligadas ao uso da 5DNet. Para eles, a mediação social é a segunda categoria mais citada $(n=99)$ e por quase todos os sujeitos do grupo, $n=32$ (Tabela 11). Ao descrever as atividades realizadas com os adolescentes, eles demonstram (a partir da sua concepção) que a tecnologia em si não é um mediador de comportamento, mas é preciso a mediação social para usar aquela ferramenta. E o que é importante, sentem-se confortáveis e têm experiência com a tecnologia. Todas as colocações do grupo associam mediação social a algum nível de uso da 5DNet.

\section{Mediação social: narrativas dos estagiários}

(...) Durante várias vezes que fiquei com Francisco e fizemos uso da ferramenta, notei que há um grande movimento dele, mas que depende muito da compreensão do estudante que medeia. (EOL; pg 178)

(...) para o estudante uma ferramenta a mais de mediação na microcultura. (EOL; pg 179)

(...) Sua proposta de permitir a troca de experiências entre os todos na 5D é muito rica. (RSB; pg 187)

(...) Durante algumas interações, pude perceber que sempre que a criança quer publicar algo em seu blog, ela precisa da nossa ajuda.(JMFS; pg 200)

(...) sua função/objetivo está relacionada com a mediação colaborativa, já que é a ferramenta auxiliar durante a interação, fazendo parte dos desafios e propondo tarefas que estão relacionadas diretamente com o labirinto. (FLO; pg 195)

(...) ótimo lugar para se comunicar com pessoas do nosso grupo e de outras 5D; mostrar novas atividades para as crianças. (ACB; pg 170)

(...) Também publiquei um jogo interessante, que levou crianças do projeto de quarta e sexta a verificarem o jogo e experimentarem. O que não foi uma mediação específica, mas um auxílio nas mediações de outros estudantes. (N/I; pg 182)

(...) Ele ia me fazendo perguntas sobre as semelhanças entre os projetos, sobre as atividades e se ele poderia mandar mensagem para qualquer pessoa, e eu fui respondendo. Essa interação me marcou, pois foi significativa em relação ao 5DNet. (ALSH; pg 190)

(...) postou uma foto que ela escolheu e pediu que a ajudássemos a escrever uma legenda. (A; pg 209)

Os adolescentes citaram a categoria mediação social $35,98 \%$ das vezes, e os estagiários, 31,63\%. É a primeira categoria mais citada entre os adolescentes e a 
segunda entre os estagiários na dimensão educação. Trata-se de um tema representativo para todos os envolvidos no projeto, tanto pelo número de citações quanto pelo quantitativo de sujeitos que fazem referência a ela (Tabela 11). Os estagiários se debruçam para compreender as possibilidades de mediação social associada ao uso da tecnologia, esse é o eixo das narrativas do grupo. No seu discurso, citam situações vivenciadas com os adolescentes, procurando alternativas e respostas às suas indagações; já para os adolescentes, é o desnivelamento saudável na troca de experiências que vem à tona quando se referem ao tema.

\subsubsection{Dimensão função executiva}

Diferente das outras categorias, a dimensão função executiva foi uma revelação inesperada acerca do uso das redes sociais em reabilitação. A possibilidade de usar uma estratégia e ter consciência sobre o seu próprio sistema cognitivo, utilizando esse conhecimento em situações sociais apropriadas é um recurso de monitoramento do próprio comportamento muito eficiente para todos os adolescentes, sobretudo aqueles que sofreram lesão cerebral no córtex pré-frontal (FORSYTH, 2010). Uma série de estudos na área da reabilitação evidencia que, ao contrário do que se espera, o funcionamento social dos jovens com lesões frontais tende a piorar com o tempo (YEATES et al., 2004). O impacto nas funções executivas tem sido um ponto focal de investigação sobre os resultados cognitivos da lesão cerebral precoce, baseado na evidência de que a região pré-frontal do cérebro é extremamente vulnerável e desempenha um papel vital na mediação de habilidades executivas (RYAN et al., 2014). Em suas narrativas, adolescentes e estagiários descrevem, constroem significados sobre alguns componentes desse complexo mecanismo de pensamento. 
$\mathrm{Na}$ Tabela 12, apresentamos as diferentes categorias que constituíram, neste estudo, a dimensão função executiva, seguida do número de sujeitos que fizeram referência a cada uma delas, além do número e da proporção de citação por grupo. Para os adolescentes, o pensamento metacognitivo representa $44 \%$ das citações, seguido do comportamento de autorregulação, que corresponde a $36 \%$, e do planejamento, que corresponde a $20 \%$ das referências citadas. O que caracteriza essa distribuição é sua concentração em um número relativamente pequeno de sujeitos. Também para os estagiários, a categoria metacognição foi a mais expressiva no grupo e corresponde a mais da metade das citações nessa dimensão, 52,73\%, seguida da categoria planejamento, com $27,27 \%$ do total, e da autorregulação, que soma $20 \%$ do total. Diferente dos adolescentes, as citações não são tão concentradas e envolvem um número maior de sujeitos. $\mathrm{Na}$ apresentação abaixo, das dimensões, retomaremos à tabela 12 sempre que necessário.

Tabela 12 - Análise descritiva dimensão função executiva: adolescentes e estagiários

\begin{tabular}{llcccccc}
\hline Dimensão & \multicolumn{2}{c}{ Categoria } & \multicolumn{3}{c}{ Adolescentes $(\mathrm{n}=33)$} & \multicolumn{2}{c}{ Estagiários $(\mathrm{n}=34)$} \\
\cline { 2 - 8 } & & Sujeitos & Citações & $\%$ & Sujeitos & Citações & $\%$ \\
\hline Função executiva & Autorregulação & 8 & 27 & 36,00 & 8 & 11 & 20,00 \\
& Pensamento metacognitivo & 5 & 33 & 44,00 & 16 & 29 & 52,73 \\
& Planejamento & 9 & 15 & 20,00 & 9 & 15 & 27,27 \\
\hline Total & & 75 & 100,00 & & 55 & 100,00 \\
\hline
\end{tabular}




\subsubsection{Categoria autorregulação}

As narrativas que deram sentido à categoria autorregulação foram referenciadas por 8 adolescentes em um total de 27 citações (Tabela 12). Essas narrativas envolveram um conjunto de experiências diversas, entre elas: o monitoramento do comportamento para a aprendizagem, como, por exemplo, voltar para casa, concentrar-se e rever a matéria; o controle de padrões de excitação, como a ansiedade, por exemplo, poder sentir-se mais tranquilo, menos eufórico; a inibição da intensidade das emoções; o controle da impulsividade, como entender limite e regras do convívio social; e a reflexão sobre seu desempenho relacionada a um conjunto de competências envolvidas na aprendizagem.

\section{Autorregulação: narrativas dos adolescentes}

(...) Eu volto nas matérias que o professor passou, tipo, chego na aula que a professora passou sobre Bhaskara, vejo lá como é que é, volto, faço e lembro. (R; pg 296)

(...) quando começou esse ano, eu falei para mim que poderia ser uma melhor pessoa, é, né? Até fui melhorando minhas notas, com 7 em matemática, ciências. Aí quando comecei a passar fiquei gostando mais do Sarah. (E; pg 306)

(...) Fico mais atenta. As matérias que eu não acho muito difícil, nem me chamam mais atenção, é tranquilo, e as matérias eu faço sem dificuldade então... Às vezes muita coisa me chama atenção. (B; pg 310)

(...) eu ficava estressada, não sabia como organizar. Ficava muito nervosa e chorava por qualquer motivo... Na hora, eu estava sentada e deu aquele frio, assim. Aí do nada, eu comecei a me preocupar e ficar descendo lágrima, igual a antes e eu não consigo controlar e vai descendo e eu vou pensando e aí tudo o mais vai... e eu não consigo... não... eu não vou pirar não. Muitas coisas mudaram pra melhor... parece que meu coração meio que dá aviso pra não se preocupar... (MB; pg 312)

(...) Mesmo quando estou atrasada pra chegar na escola, dependendo do horário, vou tranquila. Eu não tenho mais aquela euforia, como eu tinha antes, pra tudo. Aquela coisa assim... (MB; pg 316)

(...) ... Ficava agoniado para fazer logo o que eu queria... Só que agora eu já notei que isso é errado e agora, devo perguntar para ela se posso ou não dar um beijo na bochecha, como se fosse dando um “oi”... (LS; pg 301) 
(...) Eu aprendi que quando alguém quer jogar, você pergunta para ela se ela gostaria de jogar com você ou não para fazer uma parceria a ela. (R; pg 296)

Para os estagiários, o significado da regulação está relacionado à manutenção dos adolescentes em estado constante de equilíbrio, voltados para uma dada atividade. Não se trata da manutenção da atenção, mas sim de um ritmo constante que percorre a ação, sempre de forma prazerosa e sensível aos interesses dos adolescentes. Atuam como um apoio externo à regulação do comportamento, mas genuinamente envolvidos na atividade. A categoria foi citada 11 vezes, por 8 estagiários (Tabela 12), que usam os diferentes artefatos e ferramentas do sistema educacional nessas interações e fazem referência à 5DNet enquanto um ambiente constituído por recursos que favorecem essas ações.

\section{Autorregulação: narrativa dos estagiários}

(...) viu um post sobre futebol que lhe interessou muito, aproveitei a deixa e incentivei-o a comentar e, assim, foi, ele comentou neste e depois abrimos outras coisas, adicionamos mais amigos, visitamos vários blogs e vimos vários posts e, como consequência, passamos a maior parte da tarde no 5DNet. (RLSC; pg 206)

(...) Tudo aconteceu quando ele chegou à sala do projeto 5D, e eu e o Jefther demos a ideia dele tirar uma foto e colocar no perfil do seu blog. Ele aceitou e foi até o balanço dizendo que queria tirar foto naquele local. Então pegamos a câmera e tiramos a foto. Escolhemos duas, uma para ele colocar no perfil do seu blog e a outra para fazer uma postagem.(NNR; pg 216)

(...) Durante a tarde do dia 22/06, tirei fotos de uma das crianças para que ela conseguisse colocar a foto no seu avatar, postamos a foto no seu mural, escrevemos mensagens no mural de outros estudantes e editamos seu perfil. (JFLR; pg 213)

(...) Primeiramente, ela abriu alguns arquivos que postou, ia mostrando as fotos das pessoas que haviam comentado. Eu lia para ela os comentários, perguntava se ela já havia respondido... Depois, ela ficou clicando nas fotos de pessoas conhecidas e fazia o nome dela em libras ou utilizando a prancha de comunicação. (NSA; pg 185)

A proporção das citações acerca da autorregulação do comportamento é maior no grupo de adolescentes (36\%) do que no de estagiários $(20 \%)$, embora o número de 
sujeitos que fizeram referência a ela seja exatamente igual em ambos os grupos, $\mathrm{n}=8$ (Tabela 12). Na narrativa dos sujeitos, evidenciam-se diferentes momentos do processo de internalização do comportamento de autorregulação: os estagiários enfatizam e exemplificam o processo interpessoal mediado do comportamento; enquanto os adolescentes referem-se ao aspecto intrapessoal da aprendizagem, como resultado da experiência compartilhada no sistema educacional.

\subsubsection{Pensamento metacognitivo}

A categoria pensamento metacognitivo foi citada 33 vezes, por cinco adolescentes. É uma categoria muito explorada, mas por poucos sujeitos (Tabela 12). Em suas narrativas, adolescentes tecem um conjunto de reflexões conscientes de caráter intencional sobre seu processo cognitivo: percorrem o próprio pensamento, percebem o grau de dificuldade de uma tarefa equacionado com suas capacidades e desenvolvem estratégias a partir desse conhecimento. Essas reflexões são desencadeadas de maneira espontânea nas diferentes situações de interação no programa, favorecem a autonomia e a aprendizagem.

Pensamento metacognitivo: narrativas dos adolescentes

(...) $\{$ E como você faz para lembrar o nome de todo mundo?\} Eu paro, olho bem para a pessoa, entro na minha mente, penso, luto para poder saber, pergunto com que letra começa o nome da pessoa, por exemplo se for Juliana, eu falo, com que letra começa? Então falo "J", então penso: "J", aí chuto... (R; pg 294)

(...) às vezes, quando eu fazia atividade, eu demorava muito para saber como é que era a atividade... um pouco porque às vezes eu não tinha muito interesse \{quando você não tinha interesse, tinha dificuldade de entender o que era para fazer, o que é que acontecia?\} eu fazia a atividade e não participava... às vezes, tem vezes que eu presto mais atenção no jogo do que no estudante... (E; pg 303)

(...) \{Voce lê o que os outros postam na 5Dnet...?\}... Hum... não... é difícil algumas... 
(...) mas às vezes eu penso assim: "poxa, eu acho que não dá pra ser representante de turma, pois representante fala alto, como Coronel e eu não consigo. Outra coisa é que, na maioria das vezes, eu me sinto meio burra na sala. Aí, às vezes eu penso que se eu não fosse representante, eu estaria quieta e calada, sem falar nada e seria bem melhor. (MB; pg 316)

(...) não existe nenhuma coisa chata no $5 \mathrm{D}$, porque as pessoas que postam, elas pensam antes de postar, por isso não tem coisas chatas, só tem coisas legais...(TNM; pg 236)

(...) percebi que era uma pessoa muito fechada, não falava muito, acho que tinha vergonha de falar, muitas vezes. Acho que a partir que eu entrei na $5^{\mathrm{a}} \mathrm{D}$, acho que continuei o mesmo, mas, tipo que nem na escola, eu tenho uma dúvida, eu falo com o professor, e isso eu não falava antes, tinha vergonha. (GCB; pg 289)

(...) \{Como você fez para aprender o nome da Lorena?\} eu me apaixonei por uma menina que estudou comigo desde o prezinho até a $4^{\mathrm{a}}$ série, quando eu parei de estudar. Até a $4^{\mathrm{a}}$ ? É. Foi o último dia que eu pude ver ela, porque eu fiz até a $4^{\circ}$, voltei dois anos, ela foi passando, chegou no $9^{\circ}$ ano, se formou no ensino fundamental e agora eu acho que ela está no $3^{\circ}$ ano do ensino médio. Eu me lembro do nome da Lorena por causa dela. (R; pg 297)

Dezesseis $(n=16)$ estagiários citaram o pensamento metacognitivo 29 vezes (Tabela 12). Significaram essa categoria como resultado da reflexão compartilhada com os adolescentes acerca das atividades realizadas. Nas suas narrativas observa-se a intenção em apoiar essa forma de raciocínio. É uma categoria que faz uma sobreposição com a dimensão interatividade. A 5DNet é utilizada como lócus para registro e reflexão das atividades realizadas, ao registrar uma tarde de atividades, o adolescente pode refletir sobre suas ações, relembrar ou percorrer mentalmente o que fez como estratégia ou, ainda, retomar no encontro seguinte do ponto onde parou. Em algumas situações, o uso de imagens apoia o registro de atividades na rede social.

\section{Pensamento metacognitivo: narrativas dos estagiários}

(...) situações específicas onde eu desejo aproximar as crianças de determinado tema, ou lembrar uma atividade, ou um tema específico que fizemos em uma tarde passada. (N/I; pg 182)

(...) pensar sobre o que fez, se foi bom ou ruim, com quem estava e da forma como jogou (se criou novas regras ou não). (BGR; pg 193)

(...) além disso, a ferramenta dá a oportunidade de rever e refletir o que fez em outras tardes, colaborando para o exercício de sua metacognição. (JMFS; pg 200) 
(...) aproveitar um momento significativo da tarde e retomá-lo, também de uma tarde anterior ao respondermos os comentários, tentando fazer com que eles se lembrem de e reflitam sobre esse momento, talvez em algum ponto levando-os a metacognição. (RLSC; g 205)

(...) serve para exercitar a memória, já que com as interações descobrimos que, através de sua memória visual, ele é capaz de se lembrar de fatos passados. (SBR; pg 207)

(...) contribui para a formação do indivíduo, já que assim ele conhece outros interesses de outras crianças e assim passa a desenvolver a sua própria autocrítica em relação ao que vê; esses são os pontos positivos. (NNR; pg 216)

Proporcionalmente, a categoria pensamento metacognitivo foi um pouco mais representada nas narrativas dos estagiários, com 52,73\% das citações, do que nas do grupo de adolescentes, com 44\% delas (Tabela 12). Ambos os grupos detalham aspectos similares do pensamento metacognitivo, o que muda é a óptica: os adolescentes pensam sobre os seus pensamentos, avaliam o grau de dificuldade de um problema e escolhem estratégias para resolvê-lo; já os estagiários ficam centrados nas estratégias que podem utilizar com os adolescentes para que eles se desenvolvam e monitoram esse processo cognitivo.

\subsubsection{Categoria planejamento}

A capacidade de fazer planos compõe as funções executivas. A categoria planejamento foi citada 15 vezes por 9 adolescentes (Tabela 12). Em suas narrativas, os adolescentes fazem referência à capacidade de planejar, estabelecer metas e manter uma sequência de ação. Associam o planejamento a formas de organização, ou seja, organizar seu comportamento futuro em relação a situações que foram definidas como relevantes para eles. Por exemplo, planejar o cotidiano em casa, a rotina de estudo ou, ainda, como organizar um grupo para jogar. Usam lembretes como recursos mnemônicos, estratégia especialmente eficiente, pois, assim, relembram o que foi 
planejado. No entanto, em suas narrativas observa-se que alguns adolescentes começam a formar representações cognitivas das ações necessárias para fazer seus planos, até deixando esses lembretes um pouco de lado.

\section{Planejamento: narrativas dos adolescentes}

(...) me ajudou muito, porque, apesar de ser uma agenda grande e em quadradinhos, você olha tudo, está bem visível, você anota ali, sem preguiça. Deixa eu ver o que mais. Agora, todo sábado, eu acordo de manhã, tomo café ou vou comprar o pão e já vou direto fazer as coisas. Ajudar a minha mãe a lavar a área, que eu sempre gosto de, pela manhã, lavar a área e vou ajudando. Meio-dia almoço e à tarde fica livre pra o que eu quiser fazer. Antes, à tarde, eu ajudava a minha mãe e era tudo bagunçado...(MB; pg 315)

(...) organizar os horários; pegar um bloco de folha e colocar onde eu vejo mais, entendeu, onde eu vou mais, no meu quarto, essas coisas. Esqueço umas coisinhas de vez em quando, mas lembro quase tudo já... (B; pg 307)

(...) a gente gostava mais de jogar Guitar Hero, então quem ganhava jogava com o próximo... \{Você acha que essa organização funciona bem?\} Funcionou, né? Pra gente. (NSN; pg 275)

(...) Antes eu não conseguia, sei lá, organizar o que tinha que fazer e o momento certo. Agora não, eu estou mais tranquila. Assim, eu não estou levando tanto dever pra fazer em casa. Eu estou conseguindo adiantar tudo na escola, na sala de aula. Essas coisas assim. (MB; pg 312)

Nove $(n=9)$ estagiários citaram 15 vezes a categoria planejamento (Tabela 12). Juntos, significaram a categoria planejamento como a organização e o sequenciamento de uma atividade realizada em conjunto com os adolescentes, mediado pelas ferramentas e artefatos de trabalho do sistema 5D. Para eles, o procedimento de uso da 5DNet no cotidiano já é, em si, uma forma de planejamento: envolve passos, objetivos a serem alcançados, etapas a serem vencidas e lembradas. Propõem que a rede social seja um ambiente de referência para planejamento de atividades onde podem registrar etapas do planejado, rever, lembrar, e, inclusive, observar o plano do colega. Quando o adolescente encontra uma dificuldade, o estagiário procura apoiá-lo, para que pratiquem a autocorreção. 
Planejamento: narrativa dos estagiários

(...) Através do blog, a criança pode aperfeiçoar a habilidade de organizar e planejar. "Primeiro, tirar uma foto que represente algo para a criança, escolher a que mais gostou, colocá-la no blog, observar e pensar no que deve escrever para apresentar a foto às outras crianças". São sequências de atividades que trabalham com a cognição da criança. (LLCR; pg 215)

(...) podendo, dessa forma, pensar sobre o que foi feito e todas as etapas que foram cumpridas para se chegar ao objetivo final e disso tirar uma conclusão da atividade, pensando no planejamento. (BGR; pg 193)

(...) atividades trazidas por outras pessoas no 5DNet é uma forma de direcionar a tarde. (CPM ; pg 173)

(...) organizavam a tarde a partir de sugestões que viam na plataforma virtual ou passavam a tarde fazendo uso dela. (CPM ; pg 173)

(...) também como forma de organização da tarde, à medida que ela se espelha nas atividades desenvolvidas por outras crianças, ou por vezes retoma a atividade realizada através da postagem de uma atividade. (N/I; pg 182)

As citações acerca da categoria planejamento se distribuem igualmente entre os grupos, tanto no que se refere ao número de sujeitos que fazem referência a ela, quanto ao número de citações por grupo (Tabela 12). O que aproxima e diferencia a avaliação dos adolescentes, em comparação com a avaliação dos estagiários nessa categoria, é, mais uma vez, próximo ao que foi descrito pelo grupo, nas categorias autorregulação e pensamento metacognitivo: os adolescentes descrevem como já são capazes de planejar e organizar atividades relevantes para elas, ainda com um certo nível de ajuda; enquanto os estagiários são um apoio colaborativo, externo, no desenvolvimento dessa função e no planejamento estratégico de um sistema educacional computacional de atividades.

\subsection{Discussão dos dados}

O sentido de uma rede social, em última análise, é fortemente configurado pelos seus usuários, no entanto, quando tratamos da aplicação educacional desta ferramenta, este movimento segue um curso um pouco diferente. De maneira geral, parte do 
educador o desenho inicial que esta ferramenta terá, ou seja, é o gestor-tutor de rede que vai conceber, a partir de parâmetros próprios, por quem e com qual finalidade esta rede será utilizada. Com a rede social 5DNet foi diferente. Apesar do propósito educativo em foco, nasceu do interesse dos adolescentes e dos estagiários que frequentavam o programa 5D em compartilhar suas experiências com seus pares à medida em que o programa ia sendo implantado nas diferentes unidades. No processo de criação da rede teoria e prática tornaram-se complementos de uma unidade: enquanto concebíamos, utilizávamos e reformulávamos a rede social.

Com a substituição do texto manuscrito no livro de dicas para o meio eletrônico, ocorreu uma mudança de conteúdo dos registros. Abriu-se um espaço para expressão pessoal. Uma vez que abrimos o espaço para o diálogo mediado pelo computador, os adolescentes começaram e expressar-se de forma mais pessoal, deslocaram o discurso das dicas sobre jogos, desta memória coletiva dos artefatos da 5D, para uma memória coletiva acerca de cada um deles enquanto sujeito daquele processo educacional. Essa forma de diálogo emergiu em função do uso das ferramentas computacionais, o que gerou a reelaboração da expressão.

A topografia das conexões da 5DNet demonstra a presença de todos os grupos do projeto 5D, cada um a seu modo. De maneira geral todos os grupos de usuários são bem distribuídos na rede implantada. O número de usuários de uma rede é um paramento relativo porque depende das conexões estabelecidas. Constatamos que um grupo conectado e atuante no ciberespaço não é, necessariamente, o que apresenta maior numero de atores. O comportamento dos usuários de Belém ilustra este achado. Trata-se de um grupo com poucos usuários, relativamente à malha total de sujeitos, mas com presença e penetração significativas na 5DNet.

Esta estrutura de distribuição dos nós na 5DNet também demonstra que não há 
um nó centralizador que trabalhe para que a informação se torne efetiva e ao alcance de seus membros. Ela recebe, sim, como veremos a seguir, o cuidado e a atenção dos alunos de graduação em psicologia e pedagogia para que seja efetiva estavam empenhados para a rede funcionasse, mas qualquer membro do grupo, mesmo um adolescente, poderia assumir o controle da situação, isso dependendo de sua atitude e interesse, expandindo, assim, fronteiras do programa 5D. Isso significa que as estratégias de atuação dos atores da 5DNet não se baseou em uma estrutura hierárquica, ao contrário fundamentou-se em Interesse genuíno um nos outros, na confiança do grupo, sem a tentativa de controle de comportamento. Esse poder horizontal é uma característica única em uma rede educativa e foi uma conquista significativa.

As três dimensões configuradas pelos usuários da 5DNet, interatividade, educação e processos cognitivos de planejamento e execução de atividades, função executiva, caracterizam o sentido criado pelo grupo acerca do uso desta rede social em reabilitação. Essas dimensões são complementares e, em última análise, traduzem a multidisciplinariedade da área da informática educativa, pois abarcaram as tecnologias digitais de informação, comunicação e expressão, a área da educação e a área da saúde, especificamente a da reabilitação. Analisar separadamente e, em seguida, comparar a avaliação da 5Dnet feita pelos adolescentes e estagiários, nos permitiu compreender a perspectiva de uso da rede na sua totalidade, sem perder a ótica de cada grupo, o que fortalece a sua eficiência enquanto instrumento educacional. Pudemos, assim, dimensionar seu potencial de uso, mediado pelo papel social que cada grupo desempenha no programa 5D. Em momento nenhum procuramos segmentar as avaliações, nosso interesse sempre foi chegar a um uso educacional significativo da rede social para seus usuários os quais ou estão inseridos em um programa de reabilitação ou inseridos em um programa de estágio na sua graduação. 
$\mathrm{Na}$ dimensão interatividade, o adolescente com lesão cerebral nos apresenta a contemporaneidade da ferramenta: eles estão interessados em se conectar. Esses jovens têm em média 13 anos de idade, nasceram durante ou imediatamente após estabelecerse o domínio da virtualidade como sistema de interação social. Viveram esta realidade e estes recursos constituem o mundo em que cresceram, tenham ou não deficiência. É uma questão de pertencimento. Para eles, divertir-se, navegar e o uso da linguagem multimodal são os principais pontos da interatividade. Os amigos são grandes colaboradores, companheiros de mundo digital. Aprenderam que o entretenimento é constituinte da aprendizagem que se situa em torno de uma tensão calibrada entre o jogo e o prazer. As alterações cognitivas e comportamentais decorrentes da lesão cerebral são acolhidas e apoiadas pelas tecnologias da comunicação porque podem ser compensados pelos recursos do ambiente virtual, os erros não são tão graves, a impulsividade não fica aparente, as dificuldades de atenção e memória podem ser suplantadas, enfim, parte-se de um meio ambiente positivo, no sentido da sua potencialidade para a comunicação. A expansão do sistema educacional na dimensão Interatividade ocorre apoiada pelos recursos do ambiente da rede social enquanto contexto de interação que, ao apoiar e compensar as deficiências decorrentes da lesão no cérebro em desenvolvimento, abre caminhos para novas aprendizagens.

Para os estagiários, há um deslocamento da ótica de análise da dimensão interatividade. A grande questão para eles é o uso da linguagem multimodal como recurso de educacional, é no uso da linguagem multimodal que ocorre a expansão do seu processo de aprendizagem e formação. O interesse é o de conhecer o que acontece com seus pares nos outros programas, obterem parâmetros de ação e desempenho, só que estes referenciais são constituídos por imagens, som, animação e recursos gráficos, associados ou não à linguagem textual. É uma geração que associa a aprendizagem 
formal às tecnologias de comunicação. Além de ser um ambiente para diversão e engajamento em atividades e movimentos coletivos, essa vivência facilita a identificação da 5DNet enquanto instrumento educacional. Sendo uma geração de usuários das redes sociais, isso os aproxima dos adolescentes, além de facilitar o manuseio e a compreensão do uso educacional da 5DNet.

Na dimensão educação, os adolescentes e os estagiários fazem a transposição de todos os recursos da aprendizagem do sistema 5D para a 5DNet. Ressiguinificam os instrumentos e artefatos educacionais, os processos de mediação social da aprendizagem, o trabalho em grupo e analisam o seu resultado. Foi um percurso muito detalhado pelo grupo. Existem pontos de maior ênfase para um e outro. Para os adolescentes, a ênfase é no processo educacional e na co-construção do conhecimento, pois partem de uma perspectiva da aprendizagem ligada ao futuro, não fazem referência ao que passou, mas ao que enfrentam naquele momento e como podem resolver os problemas atuais com apoio do grupo, isso pode ser compreendido como a generalização do processo de aprendizagem. Esse mecanismo foi deslocado e acomodado à aprendizagem na rede social: nesse ambiente eles têm o apoio, os amigos; há um grupo de interlocutores de forma a encontrar na rede social, soluções futuras para os problemas atuais.

Já para os estagiários, o ponto de ênfase está na ação e nos artefatos mediadores da aprendizagem. Eles procuram incorporar os artefatos do programa 5D à 5DNet para favorecer o seu uso de forma contextualizada. Ainda que os estagiários não tenham centralizado a rede quanto ao número de conexões, percebemos na 5DNet algumas estruturas implícitas de poder, ou seja, algum tipo de hierarquia legitimada pelo papel social de cada grupo de usuários. A ótica e a análise da funcionalidade da rede feita pelos estagiários na dimensão educação pode ser considerada uma dessas 
hierarquizações, no sentido da influência e não da quantidade ou controle das relações estabelecidas na rede.

O fio condutor da educação, incorporado à 5DNet, está nos fundamentos e nas práticas mediadas de atividades sociais vivenciadas no contexto 5D. Ao utilizar informações, suas habilidades e a ação em atividades orientadas para os seus objetivos na 5DNet, os adolescentes têm a oportunidade de dominar as estruturas de conhecimento e habilidades que mediam a realização de tarefas socialmente significativas, expandindo assim o seu objeto de ação.

E, por fim, a construção compartilhada do conhecimento a partir de atividades socialmente mediadas constituiu-se em um ambiente muito eficiente para o desenvolvimento de habilidades executivas. Componentes como rotinas, a possibilidade de escolha da atividade a ser realizada, a negociação com os pares e o estabelecimento de relações de confiança e apoio são situações que proporcionam uma gama variada de oportunidades para os adolescentes aprenderem a dirigir suas próprias ações com a diminuição da supervisão de um adulto.

A 5DNet se constituiu enquanto um ambiente de apoio a comportamentos guiados por objetivos que incluem elementos como metas e planejamento, flexibilidade e processos de autorregulação. Em última análise, a dimensão função executiva expande as fronteiras do programa $5 \mathrm{D}$ em direção ao ajuste social comportamental e ao desenvolvimento de estratégias cognitivas de adolescentes com lesão cerebral. 


\section{CONCLUSÃO}

Nosso principal objetivo nesta investigação foi expandir o sistema educacional 5D por meio da criação de uma rede social que fosse concebida para promover o desenvolvimento de habilidades colaborativas em adolescentes com lesão cerebral. Após uma ampla pesquisa de literatura nas áreas das ciências da computação, da psicologia, da educação e da saúde, não encontramos estudos nos quais pudéssemos nos embasar. Estávamos de fato diante de um tema inédito: inserir uma rede social como apoio à reabilitação de adolescentes com lesão cerebral, uma ferramenta contemporânea e amplamente utilizada por jovens de todo o mundo.

Esta rede social, a 5DNet, foi criada, implantada, consolidada e está sendo usada por uma média de 120 adolescentes com lesão cerebral inseridos em programa de reabilitação e 120 estagiários, alunos de graduação em psicologia e pedagogia de diferentes universidades, em formação com a equipe de profissionais da Rede Sarah, em seis capitais brasileiras.

O sistema educacional 5D foi o caminho que encontramos para criar esta rede, o que nos forneceu as bases teóricas e conceituais para que pudéssemos, de forma planejada, concebê-la e desenvolver parâmetros de como utilizá-la com propósito específico na reabilitação. Nós tínhamos, então, uma estrutura educacional sólida, que ao mesmo tempo em que embasou, também sustentou e deu contorno a este experimento; no entanto, na medida em a 5DNet se consolidou, as delitações do sistema educacional foram flexibilizadas, redesenhadas, aumentadas, em última análise, expandidas.

Assim, para concluirmos este estudo faremos um paralelo entre os princípios do sistema educacional 5D - aprendizagem intergeracional, aprendizagem colaborativa, 
comunicação escrita, uso de tecnologias e resolução de problemas - com os novos significados e dimensões que tomaram após a criação da 5DNet para, em seguida, apresentarmos as possibilidades de uso educacional de uma rede social em reabilitação.

O ciclo expansivo da 5DNet foi significativo, partiu de movimentos individuais caracterizados pela apropriação da rede social na atividade compartilhada por díades ou pequenos grupos em direção ao movimento coletivo de integração dos usuários do projeto e, mais do que isso, à integração institucional na medida em que uniu em um só grupo, online, sujeitos que participavam de programas de reabilitação desenvolvidos em diferentes unidades da Federação. Neste contexto modifica-se a ecologia da aprendizagem intergeracional, uma das bases conceituais do projeto 5D.

A topografia das conexões da 5DNet demonstraram a multiplicação das possibilidades de aprendizagem intergeração, ela está distribuída dentro de um cenário que integrou em diferentes níveis adolescentes, estagiários e tecnologias digitais, envolvendo a criação de novos conhecimentos e novas práticas para uma atividade emergente, ou seja, com a implantação da 5DNet ocorreu o deslocamento e a transformação qualitativa das interações entre os grupo e diferentes zonas de desenvolvimento emergiram desta configuração social (potencialmente) para todos os usuários da rede.

Nesta mesma perspectiva multiplicaram-se as possibilidades de aprendizagem colaborativa e distribuição de poder entre o grupo. Os nós da 5DNet deram forma a uma nova estrutura social, a uma nova topologia das interações estabelecidas e construídas pelos seus atores. Uma vez que a 5DNet configurou-se como uma rede descentralizada, expandiu-se, assim, as possibilidades de redistribuição das relações de poder e troca colaborativa entre o grupo, pois qualquer nó pode assumir este papel e capitalizar força 
em um ambiente extenso, que gerou um novo elemento de ordenação das relações de poder.

Na medida em que multiplicamos as possibilidades de colaboração e ganhamos mobilidade nas relações de poder, mexemos no papel da figura mítica, pois tratava-se de um elemento central na organização da distribuição de poder quando ocorria um conflito ou dúvidas no grupo. Hoje, quando há uma dúvida, os atores podem sim recorrer à figura mítica, mas podem também criar movimentos paralelos de força (virtual) que se oponha ou corrobore à figura mítica. Antes da 5D esta possibilidade estava circunscrita a um ambiente geograficamente localizado, mas hoje perdeu esse limite e ganhou o espaço cibernético.

Com a 5DNet, as oportunidades de comunicação escrita sofreram um deslocamento, não só na sua multiplicação, como, também, na sua direção e qualificação. No projeto original a escrita estava mais voltada para a comunicação com a figura mítica, ou para o registro de descobertas no livro de dicas, ou, ainda, para um recado ou lembrete no mural coletivo. Por conseguinte, visto que criamos a rede e o deslocamento do poder, multiplicamos o número de interlocutores. Ademais, a comunicação também se transformou qualitativamente com a utilização da linguagem multimodal. O uso de imagem, som e vídeo, associados ou não à escrita, potencializa as formas de comunicação entre os atores compensando possíveis dificuldades de expressão decorrentes da lesão cerebral. É o uso de uma linguagem suplementar de forma absolutamente contextualizada. Neste ambiente, a deficiência é invisível e não há estigmas nem rótulos nas relações traduzindo-se em um caminho para a inclusão social e para o sentimento de pertencimento.

A jornada não termina aqui. Para que a comunicação se estruture no ciberespaço é preciso que cada sujeito se identifique, pois a expressão (remota) se constitui através 
desta identificação de modo a proporcionar pistas para a interação social no ciberespaço. Essa construção personalizada, ao mesmo tempo favorecida e exigida nas redes sociais, promoveu a individuação das mensagens postadas. Esses atores sociais, adolescentes e estagiários, passaram a ter elementos de identificação dentro de uma comunidade mais ampla. Neste processo de expansão ocorreu o que chamamos de multiplicação da expressão do self em uma comunidade que compartilhava interesses comuns, a qual, no projeto original, estava circunscrita à díade ou a pequenos grupos situados geograficamente ou, ainda, restrita ao diálogo com a figura mítica.

O uso das tecnologias como elemento de motivação para aprendizagem, também ganhou espaço. O ranking dos games está indexado à rede social e passou a ser constituinte das interações no ciberespaço, um elemento fundamental na integração dos atores sociais em torno de interesses comuns, calibrando a tensão do grupo entre o prazer, o desafio da competição e a comunicação. De alguma forma ocorreu o deslocamento do foco inicial da função do game na $5 \mathrm{D}$, que era promover a aprendizagem acadêmica, para a intensificação das interações sociais em torno do jogo, base para novas aprendizagens.

Desde o início deste estudo, centramos nossa atenção no desenvolvimento das habilidades sociais dos jovens com lesão cerebral. Como a Rede Sarah é uma instituição de reabilitação, não temos o foco na aprendizagem acadêmica, que é o eixo da rede de ensino. Ao mesmo tempo, sabemos que as lesões de lobo pré-frontal, frequentes nos sujeitos acompanhados no projeto 5D, impõem desafios sociais multiplicados durante a adolescência tanto em função da etapa da vida quanto da fisiopatologia do quadro neurológico e que podem trazer sérios problemas para novas aprendizagens. Isso justifica o porquê da nossa atenção às habilidades sociais e 
comportamentais, pois elas são a base para a aprendizagem acadêmica e para a qualidade de vida.

As redes sociais concentram elementos que respondem muito prontamente às demandas dos jovens como a intensificação das interações sociais, com respostas rápidas e baseadas na opinião dos colegas, além de exigir o raciocínio procedural para execução de uma tarefa. Para usar uma rede social há uma sequência de rotinas, procedimentos e normas e códigos subjetivos socias. A partir da resolução compartilhada de problemas, um dos princípios educacionais do sistema 5D, somada à aprendizagem intergeracional - os adolescentes sempre usavam a 5DNet na companhia de um estagiário que estava atendo às necessidades comportamentais destes jovens - e às características da nova ferramenta, avançamos em direção ao um desenho, inédito e contemporâneo, para uso educacional da rede social em reabilitação. Planejar, regular uma ação contínua e poder refletir sobre o seu próprio pensamento são funções que compõem a dimensão função executiva, associadas ao comportamento de uso da rede social, que se expandiram para além do contexto alvo. A dimensão educação, significada pelo grupo, reforça conceitos como aprendizagem intergeração, colaboração e mediação social em um espectro ampliado, enquanto a interatividade funciona como uma base, um território, para que todo este processo ocorra.

Algumas narrativas dos adolescentes e dos estagiários traduzem esta nova dimensão: um menino de 13 anos, que sofreu uma lesão cerebral aos 6 anos de idade refere sobre sua experiência no programa que aprendeu a compartilhar com os amigos... a ajudar...e compartilhar; uma menina do rio de janeiro, com 11 anos, que sofreu um atropelamento há dois anos, analisa que internet serve para saber sobre as coisas...melhorar a mente...melhorar a nossa inteligência; um garoto de 15 anos de idade, que sofreu um acidente automobilístico quando ia entrar no ensino médio, faz um 
depoimento pessoal percebi que era uma pessoa muito fechada, que não falava muito, acho que tinha vergonha...continuei o mesmo, mas... (se) tenho uma dúvida, eu falo com o professor; um garoto de 14 anos, que também sofreu um acidente automobilístico, analisa seu comportamento social aprendi que quando alguém quer jogar, você pergunta se ela gostaria de jogar com você ou não, para fazer uma parceria; uma menina de 13 anos, que sofreu atropelamento e ficou meses em coma, faz uma análise do seu comportamento antes era aquela correria, aquele estresse...se não houvesse aquela correria, não era nada...apesar de muita coisa ter mudado...sei lá, ter ficado quase tudo mais fácil. E finalmente, duas estagiárias fazem suas análises sobre o uso da 5DNet, enquanto ferramenta executiva, primeiro tirar uma foto que represente algo...escolher o que mais gostou, colocá-lo no blog, observar e pensar no que descrever...são sequências de atividades; outra estagiária faz referência ao planejamento e diz: também como forma de organização da tarde....retoma e atividade realizada e remonta a atividade realizada através da postagem. São narrativas plurais que guardam uma linha de raciocínio comum, todas são reflexões, pensamentos sobre os próprios pensamentos e comportamentos, baseados nas suas experiências sócio tecnológicas na 5DNet, no contexto5D.

Esta experiência nos mostrou que para compreender o uso das redes sociais digitais em educação é preciso deslocar (e retornar) o foco da ferramenta para a ecologia da aprendizagem humana, a qual pressupõe a mediação das relações sujeito-objetocontexto na aprendizagem. Neste processo, pessoas e sistemas se transformam mutuamente na medida em que interagem neste ambiente.

Em uma rede social toda atividade pode potencialmente ser explorada por seus atores para fins de aprendizagem. Isso implica dizer que os aprendizes da 5DNet não foram apenas os sujeitos individuais que tradicionalmente seriam alvo deste processo 
educativo, na situação em específico o adolescente com lesão cerebral; ao contrário, todos os envolvidos no uso da 5DNet foram aprendizes da ferramenta educacional: adolescentes, estagiários e pesquisadores.

$\mathrm{Na}$ área da educação muitas vezes um profissional exerce a tutoria do ambiente remoto, para aprendizagem. Isso é muito legítimo e compreensível, no entanto não é o único modelo. A experiência da 5DNet demonstra que as relações de poder no ciberespaço se deslocaram e abriram possibilidades para diferentes atores assumirem o controle da situação sem que perdêssemos o propósito educativo daquele ambiente. Ocorreu assim uma inversão de quem era mais capaz, até porque os mais jovens muitas vezes têm mais conhecimento sobre os recursos de navegação e algumas vezes estas diferenças irão aparecer e podem ser utilizadas de forma produtiva entre o grupo. Como em todo processo educativo há sempre uma definição de papéis sociais, e poder inverter estas relações no ciberespaço retroalimenta de forma criativa os processos de aprendizagem.

Comprovamos a nossa hipótese de que a criação da rede social 5DNet, além de expandi-los, ressignificou os objetos da ação do programa 5D. Esse movimento não apenas legitimou o uso da rede social como deu sentido à função educacional em reabilitação. Essas transformações só foram possíveis em razão das características idiossincráticas do projeto original que permitiram a expansão do seu alcance, agindo, por conseguinte, como instrumento de generalização para um amplo conjunto de processos cognitivos e sociais que não eram explicitamente o objeto educativo. 


\section{REFERÊNCIAS BIBLIOGRÁFICAS}

AHMED, O. et al. Ethical considerations in using Facebook for health care support: a case study using concussion management. PM \& R : the journal of injury, function, and rehabilitation, v. 5, n. 4, p. 328-34, 2013a.

AHMED, O. et al. Exploring the opinions and perspectives of general practitioners towards the use of social networking sites for concussion management. Journal of Primary Health Care, v. 5, n. 1, p. 36-42, 2013b.

ANDREWS, T. K.; ROSE, F. D.; JOHNSON, D. A. Social and behavioural effects of traumatic brain injury in children. Brain injury, v. 12, n. 2, p. 133-8, 1998.

BARDIN, L. Análise de Conteúdo. 1a. Ed. ed. São Paulo: Edições 70 LDA, 2011.

BLAKEMORE, S.-J. The developing social brain: implications for education. Neuron, v. 65, n. 6, p. $744-747,2010$.

BOUBÉE, N. T. A. L'activité informationnelle juvénile. Paris Hermes Science Publications, 2011.

BOYD, D. M. Friends, Friendsters, and Top 8: Writing community into being on social network sites. Disponível em:

$<$ http://www.firstmonday.org/ojs/index.php/fm/article/view/1418>. Acesso em: 31 out. 2015.

BOYD, D. M. Why youth (heart) Social network sites: the role of networked publics in teenage social life. MacArthur Foundation Series on Digital Learning - Youth, Identity, and Digital Media, v. 7641, n. 41, p. 1-26, 2007.

BOYD, D. M.; ELLISON, N. B. Social network sites: Definition, history, and scholarship. Journal of Computer-Mediated Communication, v. 13, n. 1, p. 210-230, 2007.

BRAGA, L. W; CAMPOS DA PAZ JUNIOR, A. (ED.). Método Sarah: Reabilitação Baseada na Criança e na Família. São Paulo: Editora Santos, 2008.

BRAGA, L. W. Should we empower the family? Developmental neurorehabilitation, v. 12, n. 4, p. 179-80, 2009.

BRAGA, L. W.; CAMPOS DA PAZ JUNIOR, A.; YLVISAKER, M. Direct cliniciandelivered versus indirect family-supported rehabilitation of children with traumatic brain injury: a randomized controlled trial. Brain injury, v. 19, n. 10, p. 819-831, 2005.

BRAGA, L. W.; ROSSI, L.; COLE, M. Criar uma idiocultura para promover o desenvolvimento de crianças com paralisia cerebral. Educação e Pesquisa, v. 36, n. spe, p. 133-143, 2010.

BURNETT, S.; BLAKEMORE, S. J. The development of adolescent social cognition. 
Annals of the New York Academy of Sciences, v. 1167, p. 51-56, 2009.

CAREY, J. C.; WADE, S. L.; WOLFE, C. R. Lessons learned: the effect of prior technology use on Web-based interventions. Cyberpsychology \& behavior : the impact of the Internet, multimedia and virtual reality on behavior and society, $v$. 11, n. 2, p. 188-195, 2008.

COLE M; COLE S. O desenvolcimento da criança e do adolescente. 4a. ed. Porto Alegre: ARTMED, 2004.

COLE, M. Cultural Psychology. A once and future discipline. Third Ed. ed. [s.1.] Harvard University Press, 1998.

COLE, M. The Fifth Dimension: An after- school program built on diversity. 10th Editi ed. New York: Russell Sage Faundation, 2006.

COLLINS, P.; RAHILLY, K.; RICHARDSON, I.; THIRD, A. The Benefits of Social Networking Services. Disponível em: $<$ https://www.comscore.com/por/Imprensa-eeventos/Apresentacoes-e-documentos/2014/The-State-of-Social-Media-in-Brazil-andthe-Metrics-that-Really-Matter>. Acesso em: 11 nov. 2015.

CORMODE GRAHAM; BALACHANDER KRISHNAMURTHY. Key differences between Web 1.0 and web 2.0. Journal of Chemical Information and Modeling, $v$. 53, p. 1689-1699, 2013.

D'ANDRADE, R. G. The cultural part of cognition. Cognitive Science, v. 5, n. 3, p. 179-195, 1981.

DROTAR, D. et al. Short- and long-term social outcomes following pediatric traumatic brain injury. Journal of the International Neuropsychological Society, v. 10, n. 3, p. 412-426, 2004.

ENGESTRÖM, Y. Learning by Expanding. Helsinki: Orienta-Konsultit Oy, p. 368, 1987.

FALLIS, A. . Living and Learning with New Media. Disponível em:

$<$ https://mitpress.mit.edu/sites/default/files/9780262513654.jpg $>$.

FEENEY, T.; YLVISAKER, M. Context-sensitive cognitive-behavioural supports for young children with TBI: a replication study. Brain injury : [BI], v. 20, n. 6, p. 629645, 2006.

FLAVELL, J; MILLER, P; MILLER, S. Desenvolvimento Cognitivo. Porto Alegre: ARTMED, 1999.

FORSYTH, R. J. Back to the future: rehabilitation of children after brain injury. Archives of disease in childhood, v. 95, n. 7, p. 554-559, 2010.

FRAU-MEIGS, D. Media Education. A Kit for Teachers, Students, Parents and 
Professionals. p. 185, 2006. Diponível em:

http://unesdoc.unesco.org/images/0014/001492/149278e.pdf. Acesso em: 10 de maio de 2013

FREIRE, P. Pedagogia do Oprimido. 46a.ed. ed. São Paulo: Editora Paz e Terra S/A, 2007.

GODDINGS, A. L. et al. The relationship between puberty and social emotion processing. Developmental Science, v. 15, n. 6, p. 801-811, 2012.

GRIFFIN, P.; COLE, M. Current activity for the future: The Zo-ped. Childrens' Learning in the "Zone of Proximal Development" New Directions for Chld Development. no. 23, n. October, p. 45-63, 1984.

HAYTHORNTHWAITE, C. Social networks and Internet connectivity effects. Information, Communication \& Society, v. 8, n. 2, p. 125-147, 1 jun. 2005.

JOSÉ, H.; CINTRA, M. Dimensões da Interatividade na Cultura Digital. [s.1.] Pontifícia Universidade Católica de São Paulo, 2003.

KARVER, C. L. et al. Cognitive reserve as a moderator of responsiveness to an online problem-solving intervention for adolescents with complicated mild-to-severe traumatic brain injury. Child neuropsychology : a journal on normal and abnormal development in childhood and adolescence, v. 20, n. 3, p. 343-57, 2014.

KEMMIS, S.; MCTAGGART, R. P 2 - 271. Disponível em:

$<$ https://www.google.com.br/\#q=PARTICIPATORY+ACTION+RESEARCH+Commun icative + Action + and + the + Public + Sphere + Stephen $>$.

KILOV, A. M. et al. Can teenagers with traumatic brain injury use Internet chatrooms? A systematic review of the literature and the Internet. Brain Injury 24(10): 1135-1172, 2010.

KON, IGOR; LOSENKOV, V. Friendship in Adolescence: Values and BehaviorJournal of Marriage and the Family, 1978.

KUROWSKI, B. G. et al. Online Problem-Solving Therapy for Executive Dysfunction After Child Traumatic Brain Injury. Pediatrics, v. 132, n. 1, p. e158-e166, 2013.

KUROWSKI, B. G. et al. Long-term Benefits of an Early Online Problem-Solving Intervention for Executive Dysfunction After Traumatic Brain Injury in Children: A Randomized Clinical Trial. JAMA pediatrics, v. 168, n. 6, p. 523-31, 2014.

LACERDA SANTOS, G; BRAGA, C. Tablets, laptops, computadores e crianças pequenas: Novas linguagens, velhas situações na educação infantil. Brasília: Liber Livro Editora Ltda, 2012.

LACERDA SANTOS, G.; GALÁN, J. . (ED.). Informática e lelemática na Educação. Brasília: Liber Livro Editora Ltda, 2012. 
LECUSAY, R.; ROSSEN, L.; COLE, M. Cultural-historical activity theory and the zone of proximal development in the study of idioculture design and implementation.

Cognitive Systems Research, v. 9, n. 1-2, p. 92-103, 2008.

LÉVY, P. Cibercultura. 1a. edição ed. Rio de janeiro Editora 34, 1999.

LEWIN, K. Action Research and Minority ProblemsJournal of Social Issues, 1946.

Disponível em: <http://onlinelibrary.wiley.com/doi/10.1111/j.1540-

4560.1946.tb02295.x/full/nhttp://libezproxy.open.ac.uk/login?url=http://search.ebscoho st.com/login.aspx?direct $=$ true $\& d b=$ cja $\& A N=16473285 \&$ site $=$ eds-

live\&scope $=$ site $\backslash n h t t p: / / d o i . w i l e y . c o m / 10.1111 / j .1540-4560.194>$

MANZINI, E. Entrevista semi-estruturada: análise de objetivos e de roteiros. Seminário internacional sobre pesquisa e estudos ..., p. 10, 2004. Diponível em

http://www.sepq.org.br/IIsipeq/anais/pdf/gt3/04.pdf. Acesso em :08 de maio de 2012

MIZUKO, I. CREATING \& CONNECTING // Research and Guidelines on Online Social - and Educational - Networking NATIONAL SCHOOL BOARDS

ASSOCIATION. Massachusetts: MIT Press, 2009.

NARDI, B. A. Context and Consciousness. London: MIT Press, 1996.

O'REILLY, T. What Is Web 2.0 Design Patterns and Business Models for the Next

Generation of Software. Disponível em: <http://oreilly.com/web2/archive/what-isweb-20.html>. Acesso em: 27 out. 2015.

OLIVEIRA, M. K. VIGOTSKI. A prendizado e desenvolvimento um processo sóciohistóricoSão PauloEditora Scipione, , 1999.

OQUIST, P. The Epistemology of Action Research. Acta Sociológica, v. 21, p. 143$163,1978$.

PRIGATANO, G. P.; GUPTA, S. Friends after traumatic brain injury in children. The Journal of head trauma rehabilitation, v. 21, n. 6, p. 505-13, 2006.

RAGHAVENDRA, P. et al. Why aren't you on Facebook?: Patterns and experiences of using the Internet among young people with physical disabilities. Technology and Disability, v. 24, n. 2, p. 149-162, 2012.

RAGHAVENDRA, P. et al. "I could never do that before": Effectiveness of a tailored Internet support intervention to increase the social participation of youth with disabilities. Child: Care, Health and Development, v. 39, n. 4, p. 552-561, 2013.

RECUERO, R. Redes sociais na Internet. Porto Alegre: Editora Sulina, 2009.

RYAN, N. P. et al. Social communication mediates the relationship between emotion perception and externalizing behaviors in young adult survivors of pediatric traumatic brain injury (TBI). International journal of developmental neuroscience : the official 
journal of the International Society for Developmental Neuroscience, v. 31, n. 8, p. 811-9, 2013.

RYAN, N. P. et al. Predictors of very-long-term sociocognitive function after pediatric traumatic brain injury: evidence for the vulnerability of the immature "social brain". Journal of neurotrauma, v. 31, n. 7, p. 649-57, 2014.

SANNIO, A; GANIELS, H; GUTÍÉRREZ, K. D. (ED.). Learning and Expanding with Activity Theory. New York: Cambridge University Press, 2009.

SAWAYA, M. Dicionário de Informática e Internet: Inglês Português. [s.l: s.n.]. SHARE POINT - OFFICE. What is SharePoint_ - Office Support. Disponível em: $<$ https://support.office.com/en-us/article/What-is-SharePoint-97b915e6-651b-43b2827d-fb25777f446f $>$. Acesso em: 15 jan. 2015.

STALD, G. Youth, Identity, and Digital Media. Disponível em:

$<$ https://mitpress.mit.edu/sites/default/files/9780262524834_Youth_Identity_and_Digita 1_Media.pdf>.

STEINBERG, L. Risk Taking in Adolescence. Current Directions in Psychological Science, v. 16, n. 2, p. 55-59, 2007.

TRIPP, D. Pesquisa-ação: uma introdução metodológica. Educação e Pesquisa, v. 31, n. 3, p. 443-466, 2005.

TURKSTRA, L. S.; MCDONALD, S.; DEPOMPEI, R. Social information processing in adolescents: data from normally developing adolescents and preliminary data from their peers with traumatic brain injury. The Journal of head trauma rehabilitation, $v$. 16, n. 5, p. 469-483, 2001.

VIEIRA, B. 75\% of Millennials in Brazil Either Access the Internet on Multiple Platforms or Exclusively on Mobile. Disponível em:

$<$ http://www.comscore.com/Insights/Data-Mine/75-of-Millennials-in-Brazil-EitherAccess-the-Internet-on-Multiple-Platforms-or-Exclusively-on-Mobile>. Acesso em: 20 jan. 2016.

VIGOTSKI, L. S. A Formação Social da Mente. 5a.Ed. ed. São Paulo: Martins Fontes, 1994a.

VIGOTSKI, L. S. Pensamento e Linguagem. 1a. Ed. ed. São Paulo: Martins Fontes, $1994 b$.

WADE, S. L. et al. Preliminary efficacy of a Web-based family problem-solving treatment program for adolescents with traumatic brain injury. The Journal of head trauma rehabilitation, v. 23, n. 6, p. 369-377, 2008.

WADE, S. L. et al. Brief report: Description of feasibility and satisfaction findings from an innovative online family problem-solving intervention for adolescents following traumatic brain injury. Journal of pediatric psychology, v. 34, n. 5, p. 517-522, 2009. 
WADE, S. L. et al. A randomized trial of teen online problem solving for improving executive function deficits following pediatric traumatic brain injury. The Journal of head trauma rehabilitation, v. 25, n. 6, p. 409-415, 2010.

WADE, S. L. et al. Effect on Behavior Problems of Teen Online Problem-Solving for Adolescent Traumatic Brain Injury. Pediatrics, v. 128, n. 4, p. e947-e953, 2011.

WADE, S. L. et al. A Randomized Trial of Teen Online Problem Solving: Efficacy in Improving Caregiver Outcomes After Brain Injury. Health Psychology, v. 31, n. 6, p. 767-776, 2012.

WADE, S. L.; MICHAUD, L.; BROWN, T. M. Putting the pieces together: preliminary efficacy of a family problem-solving intervention for children with traumatic brain injury. The Journal of head trauma rehabilitation, v. 21, n. 1, p. 57-67, 2005.

WADE, S. L.; WOLFE, C. R.; PESTIAN, J. P. A web-based family problem-solving intervention for families of children with traumatic brain injury. Behavior research methods, instruments, \& computers : a journal of the Psychonomic Society, Inc, v. 36, n. 2, p. 261-269, 2004.

WERTSCH, J. V.; TULVISTE, P. L. S. Vygotskyand contemporary developmental psychology. Developmental Psychology, v. 28, n. 4, p. 548-557, 1992.

YEATES, K. O. et al. Short- and long-term social outcomes following pediatric traumatic brain injury. Journal of the International Neuropsychological Society, v. 10, n. 03, 2004.

YLVISAKER, M. et al. Behavioural interventions for children and adults with behaviour disorders after TBI: A systematic review of the evidence. Brain Injury, v. 21, n. 8, p. 769-805, 2007.

YOUNG, N. L. et al. The Internet is valid and reliable for child-report: An example using the Activities Scale for Kids (ASK) and the Pediatric Quality of Life Inventory (PedsQL). Journal of Clinical Epidemiology, v. 62, n. 3, p. 314-320, 2009.

ZHU, Y.-Q. et al. How does Internet information seeking help academic performance? The moderating and mediating roles of academic self-efficacy. Computers \& Education, v. 57, n. 4, p. 2476-2484, 2011. 


\section{APÊNDICE A - ENTREVISTA ESTUDANTES}

Nome: ACB

Unidade: Brasília

As perguntas abaixo são um roteiro para que possamos refletir sobre o sentido da 5DNet. Você pode respondê-las uma a uma ou fazer um relato corrido que contemple os diferentes tópicos. Fique a vontade para fazer referência a qualquer tema que não tenha sido contemplado neste roteiro, mas que tenha relação direta ou indireta com a 5DNet.

1) Com que frequência, em que situações e com quais objetivos você usa o 5DNet?

Tento sempre postar alguma coisa interessante que fizemos a tarde ou na anterior . Ultimamente não tenho feito isso com tanta frequência no meu 5DNet, tento fazer a criança postar no dela. Faço isso mais como uma forma de mostrar as outras crianças e estudantes o que fizemos a tarde e dar ideias para outras crianças e estudantes de atividades. Mas também para crianças, como a Érika, se sentirem incluídas na 5D e estimuladas a realizar outras atividades que não as que elas normalmente realizam.

2) Para você, qual a função desta ferramenta dentro da microcultura 5D?

Comunicação entre os participantes da 5D, dividir experiências e mostrar as atividades realizadas na $5 \mathrm{D}$.

3) Durante o semestre, você mediou a interação de alguma criança na 5DNet? Relate com uma pequena descrição e reflexão.

Normalmente os estudantes tem sempre de lembrar as crianças de postar no 5DNet, porém a Érika, na maioria dos dias está disposta a postar coisas na 5DNet e adora os comentários. Normalmente, posta receitas que gosta ou que sabe fazer. Isso fez a Érika se aproximar mais do computador, usá-lo mais e também, em certa medida, a leitura e a escrita. Também se aproximou de outros estudantes e crianças que vem comentar as suas receitas. E isso é muito importante para o seu desenvolvimento social e também escolar.

4) Relate sua impressão sobre o 5DNet, descrevendo pontos positivos e restritivos.

Positivos: ótimo lugar para se comunicar com pessoas do nosso grupo e de outras 5D; mostrar novas atividades para as crianças; aumentar a autoestima das crianças através dos comentários nos posts feitos por elas.

Negativos: acho um pouco difícil de usar a ferramenta; não é muito visual para as crianças que não sabem ler e postar sozinhas; por ter senha, algumas crianças esquecem sua senha e não conseguem postar. 
Acho que por as crianças durante à tarde não quererem postar, mesmo que os estudantes insistam, a 5DNet acabou sendo deixada de lado pelos estudantes também, pois é uma forma de comunicação e se as crianças não entram, a comunicação fica enfraquecida.

5) Pensando na utilização do 5DNet e em como torna-lo melhor, deixe suas sugestões/análise.

Acho que poderia ter um link direto com a entrada no labirinto, pois fazer o login na 5DNet, às vezes pode ser um pouco difícil, e se a ferramenta já aparecesse aberta quando entrássemos no labirinto, talvez houvesse mais interesse. As letras também poderiam ser em tamanho maior, pois algumas crianças não conseguem enxergar o que está escrito.

6) Você lê o que os outros postam na 5DNet?

Algumas vezes leio o que outras crianças e estudantes postam para ter ideia do que fazer a tarde e sugerir para a criança que estou brincando. Também leio posts que acho interessante e coloco comentários.

Nome: Não identificado

As perguntas abaixo são um roteiro para que possamos refletir sobre o sentido da 5DNet. Você pode respondê-las uma a uma ou fazer um relato corrido que contemple os diferentes tópicos. Fique a vontade para fazer referência a qualquer tema que não tenha sido contemplado neste roteiro, mas que tenha relação direta ou indireta com a 5DNet.

1) Com que frequência, em que situações e com quais objetivos você usa o 5DNet?

Mais ou menos uma vez a cada 15 dias. Sempre que usei ou estimulei o uso pela criança, foi para utilizar a ferramenta e alimentar, como recomendado quando da introdução.

2) Para você, qual a função desta ferramenta dentro da microcultura 5D?

A função é, a meu ver, introduzir a criança no uso das "redes sociais", de forma mais ou menos integrada com a microcultura que nós estudantes compomos.

3) Durante o semestre, você mediou a interação de alguma criança na 5DNet? Relate com uma pequena descrição e reflexão.

Uma vez eu disse que queria mexer no 5DNet e me pus a postar com o Alessandro do meu lado! Vi uma foto do Chaves e postei uma também, e ele colocou uma do seu Madruga. Foi uma das primeiras vezes que ele fez uso do artefato. Acho que a ferramenta sendo atrativa para o estudante, acaba estimulando o uso também pela criança. 
4) Relate sua impressão sobre o 5DNet, descrevendo pontos positivos e restritivos.

É uma experimentação louvável e mesmo necessária, na medida em que as "redes sociais" vêm influenciando na sociabilidade cada vez mais das pessoas. De ponto negativo algumas coisas técnicas, como quando nós erramos a senha, o nome também se apaga. Acho que a similaridade com as redes sociais do momento (Facebook e Orkut) poderiam ajudar muito.

Uma hipótese é que a interação é bem limitada, muito mais entre as estudantes do que entre as crianças, mas também entre e com as crianças. Acho que a 5DNet sendo desinteressante ou limitada para o estudante, acaba que à tarde toma outros rumos que não a 5DNet.

5) Pensando na utilização do 5DNet e em como torna-lo melhor, deixe suas sugestões/análise.

Talvez se a participação estudantil na 5DNet for análoga à da tarde, no sentido de colaboração, paridade, isso acabe por estimular o uso.

6) Você lê o que os outros postam na 5DNet?

Os usuários postam mais fotos do que texto, mas leio pouco o que chega a ser postado. Talvez por não passar muito tempo no 5DNet. Mas as fotos com a legenda, sim. Há um tempo costumava entrar o horário das $14 \mathrm{~h}$, mas não mais.

Nome da estudante: CPM

Unidade: Brasília

As perguntas abaixo são um roteiro para que possamos refletir sobre o sentido da 5DNet. Você pode respondê-las uma a uma ou fazer um relato corrido que contemple os diferentes tópicos. Fique a vontade para fazer referência a qualquer tema que não tenha sido contemplado neste roteiro, mas que tenha relação direta ou indireta com a 5DNet.

1) Com que frequência, em que situações e com quais objetivos você usa o 5DNet?

Hoje em dia eu uso pouco a 5DNet, em torno de uma vez em 15 dias. Quando sobra tempo, na reunião das 14h. Eu aproveito para comentar nos posts das crianças e tentar movimentar um pouco a ferramenta. Gosto de postar sugestões de atividades que possam interessar as crianças e orientar a tarde. Sempre que vejo uma atividade que acredito interessar algumas das crianças do projeto, posto lá e mostro para elas. Sempre sugiro que façam e me contem depois, mas quase nunca recebo resposta, ou seja, faço uso da ferramenta para sugerir atividades com objetivo de orientar à tarde e propor algo novo, apoiar e incentivar as atividades feitas pelas crianças para manter a cultura do uso da ferramenta. 
2) Para você, qual a função desta ferramenta dentro da microcultura 5D?

Podemos considerar várias funções que a 5DNet pode ter. No entanto, eu acredito que neste momento, ela exerce a mesma função do Hints book do projeto original. Lá as crianças postam imagens ou comentários de atividades que fizeram, compartilhando sugestões com os outros. Eu mesma gosto de postar sugestões de atividades no 5DNet para fugir da rotina do labirinto. Outra função que noto é a de comunicação com os estagiários que mudaram de grupo. Muitas crianças buscam a ferramenta para se comunicar com esses antigos estagiários. Não noto muito interesse das crianças nessa comunicação com as pessoas de outras sedes. Apesar de tentarmos motivá-los a perguntar, pesquisar sobre outros projetos, eles não se mostram muito interessados.

Semestre passado, quando o uso do 5DNet era mais intenso, notava que algumas crianças o utilizavam como labirinto, quanto tinham aversão ao último. Organizavam a tarde a partir de sugestões que viam na plataforma virtual ou passavam a tarde fazendo uso dela: vendo os posts, comentando, postando piadas.

3) Durante o semestre, você mediou a interação de alguma criança na 5DNet? Relate com uma pequena descrição e reflexão.

Semestre passado mediei várias interações na qual foi feito o uso da 5DNet. Já nesse semestre, tive poucos momentos com uma criança que fez uso da ferramenta. Em uma tarde com o Léo, em que ele só queria ver vídeos, sugeri que entrasse no meu 5DNet para ver um post que eu tinha feito. Sem saber usar a ferramenta, o Leo pediu que logasse no meu para acessarmos. Lemos o meu post e ele disse ter se interessado pelo jogo, então acessamos pelo link e passamos a tarde criando músicas no Incredibox. No final de cada música criada, havia a possibilidade de salvar e enviar para os amigos. Tentei resgatar com ele e pedi para que quem jogasse, postasse a música que criou no meu 5DNet. O Léo salvou e pediu para no final colocarmos nos comentários, e assim fizemos.

As sugestões de atividades trazidas por outras pessoas no 5DNet é uma forma de direcionar a tarde fugindo um pouco da rotina do labirinto. O Léo é uma criança que se recusa a usar o labirinto e tende a passar todas as tardes do projeto fazendo a mesma atividade, assistir vídeos aleatórios no youtube. Romper com essa rotina é sempre um desafio que cria situações difíceis de lidar. Nessa tarde, consegui apresentar uma atividade do agrado do Léo através de uma ferramenta da microcultura. Acredito que isso é importante para ele ver que existem opções interessantes, diminuindo a aversão de algumas crianças a certas ferramentas. Quando postamos a música feita por nós dois no meu perfil é uma forma de afirmação do Léo como componente desse grupo que divide uma microcultura. Por vezes, nos questionamos sobre a rejeição do Léo a fazer atividades em grupo e interagir com outras crianças, essa situação foi uma forma sutil dele participar e se mostrar no grupo.

4) Relate sua impressão sobre o 5DNet, descrevendo pontos positivos e restritivos.

Um dos pontos mais negativos em relação ao 5DNet é a falta de capacitação nossa e das crianças de utiliza-la. Muitas crianças acham difícil fazer posts através do 5DNet. As 
limitações da ferramenta também inviabiliza a utilização de muitas crianças. A Erika, que muito se interessa pelo blog, não consegue ver os comentários que ela escreve, devido ao tamanho da letra. Como não é possível postar imagens nem vídeos nos comentários, fica impossível a comunicação com crianças não alfabetizadas. Noto que fazer o login todas às vezes ao entrar também afastam as crianças do uso. Como só se usa o 5DNet a partir do labirinto, seria mais fácil se os dois fossem vinculados, ou seja, ao abrir o meu labirinto, o meu 5DNet abrisse automaticamente. Há muitas opções de ferramentas e páginas dentro do 5DNet, o que dificulta a navegação das crianças. Acredito que simplificando, deixando a página do perfil com o mural de mensagem e um feed de posts mais recentes, a navegação, as crianças se aventurariam mais ao explorar o 5DNet. A dificuldade para se postar vídeo também atrapalha o uso, além das imagens postadas ficarem imensas, impossibilitando a visualização.

A ferramenta apresenta vários aspectos positivos que podem facilitar a interação, como já mencionados. No entanto, para isso ocorrer com maior frequência é necessário maior engajamento de todos os participantes. Os estagiários têm papel fundamental para incentivar o uso, sugerindo atividades, comentando nos posts, motivando a criança na interação a postar, e é preciso ser mais trabalhado isso com os estudantes. A questão da leitura e escrita para as crianças que tem receio em exercer tais atividade podem ser trabalhadas de uma forma lúdica através da 5DNet também.

Concluindo, para aumentar o uso da ferramenta é necessário fazer as adaptações técnicas nela, mas, acima de tudo, criar uma cultura de uso.

Eu diria que isso ocorreu devido a dificuldade de navegação dos usuários. O mural de mensagem no perfil foi uma grande descoberta nossa, que já existia desde a criação do 5DNet, no entanto, ninguém sabia como colocar. Talvez se o blog fosse mais personalizado, se fosse possível decorar a sua página de acordo com o seu gosto (templates, figuras, vídeos), motivaria mais as crianças a usarem, principalmente aquelas não alfabetizadas. Acredito que as modificações técnicas já facilitariam bastante o uso (facilidade ao postar vídeos e imagens, possibilidade de comentar sem ser só com a escrita, ou seja, fazendo uso de figura e vídeo, simplificação da ferramenta), pois é preciso que a ferramenta seja motivadora para as crianças e assim criarmos uma cultura de utilização. Este hábito depende tanto de nós como da melhoria técnica da ferramenta.

5) Pensando na utilização do 5DNet e em como torna-lo melhor, deixe suas sugestões/análise.

Acho que já abordei bem esse tema nas questões acima. Eu simplificaria a navegação, acrescentaria opções para inclusão de crianças não alfabetizadas e, ensinaria os estagiários a utilizarem a ferramenta. É muito importante também ter tempo para usá-la. Elaborar as respostas do Og@MM nos toma todo o horário da reunião das 14h, o que dificulta a navegação. A participação dos estagiários é essencial para servir de modelo para as crianças.

6) Você lê o que os outros postam na 5DNet?

Sim, toda vez que acesso. Sigo uma rotina de abrir, ler as últimas páginas de publicações, comenta-las, caso ache algo interessante e depois responder os meus 
comentários, caso alguém tenha deixado um. Quando tenho algo novo para postar, termino fazendo isso. Acho que esta é uma questão essencial para o bom funcionamento da ferramenta, pois diversas vezes postamos e não recebemos comentários, ou iniciamos uma conversa que se encerra por ali. Não há muito feedback nem dos estagiários e nem das crianças no 5DNet. Mas, isso envolve hábito e habilidade de manuseio da ferramenta.

Nome da estudante: CCNM

Unidade: Brasília

As perguntas abaixo são um roteiro para que possamos refletir sobre o sentido da 5DNet. Você pode respondê-las uma a uma ou fazer um relato corrido que contemple os diferentes tópicos. Fique a vontade para fazer referência a qualquer tema que não tenha sido contemplado neste roteiro, mas que tenha relação direta ou indireta com a 5DNet.

1) Com que frequência, em que situações e com quais objetivos você usa o 5DNet?

Desde o começo do semestre, utilizei o 5DNet apenas uma vez para postar um vídeo. Das outras vezes que tentei colocar fotos tive muita dificuldade em conseguir postá-las, então acabei fazendo outra atividade. A situação que utilizo essa ferramenta é quando quero registrar alguma atividade que fiz durante a tarde com alguma criança, mas só se ela quiser postar a foto junto comigo e se isso fizer parte da nossa interação durante a tarde, e o objetivo sempre é registrar alguma atividade da tarde e, em alguns casos até incentivar que determinada atividade seja feita para depois colocarmos no 5DNet.

2) Para você, qual a função desta ferramenta dentro da microcultura 5D?

Acredito que a função seja enriquecer as atividades e as interações. Como as crianças gostam de ter esse perfil no 5DNet e se comunicar com outras crianças, acho que também tem uma função de comunicação com o grupo. Como por exemplo, favorecer a comunicação entre as unidades que tem o projeto. Também é um espaço de registro, o que facilita e organiza as atividades que são realizadas as tardes.

3) Durante o semestre, você mediou a interação de alguma criança na 5DNet? Relate com uma pequena descrição e reflexão.

Vivenciei duas tardes que envolveram o 5DNet.

A primeira foi com a Laura e a ferramenta foi utilizada para que ela me mostrasse e visse os amigos que tinha no seu perfil. Foi abrindo cada página, clicando nas fotos dos perfis dos amigos e, uma vez ou outra, quando tinha uma foto de alguma atividade que ela gostou abria a foto para vermos. E quando sugeri que colocássemos a nossa foto sobre aquela, ela não quis e passamos para outra atividade. 
A segunda vez foi quando eu, Maria, Tati e Érika brincamos de circo. A grande história aconteceu porque foi sugerido que eu filmasse a apresentação do circo e depois colocaríamos no 5DNet para todo mundo ver. Filmei e a Tati junto com a Érika foram colocar o vídeo da apresentação, mas eu e a Maria continuamos brincando com os bambolês e filmei. No final, Maria quis escolher um dos vídeos dela e como ela não lembrava mais da senha ou do usuário do seu perfil, postamos pelo meu. Tivemos dificuldade em conseguir encontrar o vídeo e também em conseguir que ele fosse postado, pois dava erro o tempo todo e o arquivo não era reconhecido. Dessa forma, Maria perdeu o interesse e quis fazer outra coisa. Combinamos que eu tentaria colocá-lo depois e até quando eu estava sozinha tentando foi difícil. Depois de algumas tentativas consegui colocar uma foto porque o vídeo não postava de jeito nenhum.

Bem, acredito que a ferramenta tem muito a acrescentar para as atividades, mas o seu funcionamento acaba deixando um desinteresse porque os vídeos não conseguem ser postados e assim as crianças não tem muita paciência de ficar insistindo. Entretanto, geralmente, quando falamos em fazer alguma coisa e depois postar na 5DNet, elas ficam animadas para todos verem.

4) Relate sua impressão sobre o 5DNet, descrevendo pontos positivos e restritivos.

Em minha opinião, essa ferramenta tem como pontos positivos o de funcionar quase como uma "rede social", favorecendo a comunicação entre as crianças e estagiários; ser um local informal; permitir que as atividades realizadas sejam de conhecimento geral; reunir as pessoas envolvidas no projeto de uma forma divertida; incentivar as crianças a compartilhar aquilo que elas fazem, permitindo um diálogo entre elas e sobre o que fizeram, de forma que se aproximam. Como ponto negativo, acredito que a dificuldade ou talvez o desconhecimento por como utilizar a ferramenta, no sentido funcional do programa.

Acho que a ferramenta foi se enfraquecendo porque os estudantes tem dificuldade em manuseá-la e assim, acaba se tornando distante das ferramentas que utilizamos. As crianças usam essa ferramenta para registrar o que aconteceu durante a tarde, então em algumas tardes não existe muito que publicar, ficando sem postar nada. Acho que ainda falta um pouco de familiaridade, aproximação e internalização das coisas que podem ser feitas com a ferramenta. Porque o labirinto já é muito utilizado e isso porque as tardes são programadas e organizadas com base nele. Dessa forma, as crianças já sabem que em algum momento vão acessar o labirinto e que ele tem coisas a oferecer que os divertem. Talvez o 5DNet apenas não tenha sido totalmente explorado ou apresentado para as crianças de uma forma que eles vão acha-lo divertido e assim, querer acessá-lo. E como os estudantes também utilizam para as atividades e muitas vezes com alguma ligação com as crianças, a ferramenta vai deixando de se usada.

5) Pensando na utilização do 5DNet e em como torna-lo melhor, deixe suas sugestões/análise.

Conversando com uma criança, hoje, a respeito do assunto, fiquei pensando sobre o que ela me falou. Ela me disse que gostaria que fosse uma coisa parecida com o "facebook". Então me perguntei o motivo dela ter feito essa comparação e ter dito isso. Acho que deve ser por causa das muitas atividades que existem através dessa ferramenta. Como as 
crianças gostam muito de jogar, talvez o 5DNet pudesse remeter alguns jogos, talvez algum que possa ser jogado entre elas, cada um acessando um site. Isso poderia ser uma atividade sugerida em alguma sala do labirinto. Acredito que para os estudantes se interessarem mais, pudesse ser feito alguma coisa a respeito do funcionamento da ferramenta, porque muitos estudantes gostam de colocar fotos, vídeos e comentar as fotos que são postadas por outras crianças. Talvez um local que as atividades ficassem mais expostas ou algum mecanismo mais interativo com as crianças.

6) Você lê o que os outros postam na 5DNet?

Quando acessei essa ferramenta procurei encontrar os perfis das crianças que participam aqui da tarde, respondendo o que elas tinham colocado ou comentando as fotos postadas. Apesar de não responder as coisas das crianças de outros locais, leio o que elas escrevem, pois acho interessante saber o que está acontecendo nas outras unidades.

Nome: EOL

Unidade: Brasília

As perguntas abaixo são um roteiro para que possamos refletir sobre o sentido da 5DNet. Você pode respondê-las uma a uma ou fazer um relato corrido que contemple os diferentes tópicos. Fique a vontade para fazer referência a qualquer tema que não tenha sido contemplado neste roteiro, mas que tenha relação direta ou indireta com a 5DNet.

1) Com que frequência, em que situações e com quais objetivos você usa o 5DNet?

Utilizo o DNet geralmente no período que temos das 14 às 15 horas, para mandar mensagens e organizar atividades. Geralmente, teço comentários nos posts mais recentes, estimulando, participando e elogiando atividades que crianças e estudantes fizeram. Se eu vejo uma atividade bacana e acho que combine com a criança que estou na díade, acabo sugerindo que usemos a ferramenta a fim de mostrar o que tenho visto, como forma de incentivo e modelo para atividades que podem se desenvolvidas. Utilizo a 5DNet para postar atividades realizadas durante a tarde com a criança e também para postar sobre algo interessante a fim de estimular a participação da criança.

2) Para você, qual a função desta ferramenta dentro da microcultura 5D?

Trouxe para o projeto a possibilidade das crianças se conhecerem entre as 5Ds do país e na sua própria $5 \mathrm{D}$, fato que é bem positivo e que ajuda no nosso maior objetivo, o desenvolvimento social. Nesse ponto foi possível observar entre os usuários, crianças e estudantes, que a ferramenta possibilitou compartilhar produções e atividades interessantes, além de fornecer um espaço para aprender, tirar dúvidas e fazer amizades, desenvolvendo assim, a metacognição e o desenvolvimento real, não só das crianças, mas dos estudantes também. A 5DNet acaba se tornando um facilitador para as mediações através das atividades postadas no blog. 
3) Durante o semestre, você mediou a interação de alguma criança na 5DNet? Relate com uma pequena descrição e reflexão.

Durante o semestre fiquei com poucas crianças que fizeram uso do 5DNet, apesar disso quando mediei o seu uso foram em situações bem distintas.

"Francisco pegou a mensagem que tinha um desenho do piquenique, entrou no labirinto e me apontou o desenho e a 5DNet, perguntei se ele queria postar o desenho na 5DNet, o mesmo disse que sim, entramos no perfil dele, procuramos a imagem e carregamos ela no blog. Na hora de escrever algo, Francisco escreveu seu nome e o meu no título do post e depois escreveu na descrição a hora que seria o piquenique, assim como estava na mensagem dele enviada a ele". (Descrição da tarde com Francisco).

Nesse caso, noto um grande interesse por parte da criança em fazer uso da ferramenta, entretanto, ela não apresenta recursos suficientes para que esta use sozinha ou então que compreenda. Durante várias vezes que fiquei com Francisco e fizemos uso da ferramenta, notei que há um grande movimento dele, mas que depende muito da compreensão do estudante que media, pois acredito que Francisco use a ferramenta apenas como um recurso visual, para postar as atividades artísticas que faz, e ver as atividades de alguns colegas.

Em outro caso, em uma tarde com Alessandro, percebi pouco interesse dele no uso da ferramenta, como vemos no trecho de um diário de campo:

"Perguntei a Alessandro se ele tinha 5DNet, ele disse que sim, entrou e vi que tinha poucos amigos. Então, perguntei se ele não queria adicionar ninguém, inclusive eu, que ele não tinha como amigo ainda. Ele topou, adicionou algumas pessoas, depois saiu e quis jogar na internet.” (Descrição da tarde com Alessandro)

Notei nessa tarde, que mesmo com a mediação para incentivar o uso da ferramenta, mostrando o perfil de várias pessoas e nos perfis mostrando atividades postadas, a 5DNet acabou não sendo de interesse dele e foi deixada de lado.

4) Relate sua impressão sobre o 5DNet, descrevendo pontos positivos e restritivos.

Os pontos positivos são que aproxima as crianças entre os projetos 5D de Brasília e de outras unidades através das postagens que tem um interesse compartilhando, além de ser para o estudante uma ferramenta a mais de mediação na microcultura.

Os pontos negativos, acredito que é, principalmente para as crianças do grupo de pc, uma ferramenta que não tem tantos recursos úteis, pela dificuldade visual e de compreensão e não-alfabetização.

Acredito que seu uso tem ficado de lado na 5D, porque o grupo de crianças tem mostrado pouco interesse, apesar do movimento de incentivo nas mensagens dizendo "legal a atividade, que tal postar na 5DNet?". Com a falta de interesse das crianças, acaba ficando desmotivante para nós estudantes ficar postando coisas, sendo que apenas outros estudantes acabam vendo e comentando. 
5) Pensando na utilização do 5DNet e em como torna-lo melhor, deixe suas sugestões/análise.

Acredito que a ferramenta é muito boa, o que acaba faltando para que seu uso seja efetivado é que seu uso se torne um hábito, não só dos estudantes, mas das crianças também, assim como é o uso do labirinto e jogos. Acho que além de ser um hábito a 5DNet tem que ser mais explorada por todos, já que é uma ferramenta nova e sem conhecimento de suas funcionalidades acaba ficando sem estímulo para ser criado esse hábito de uso.

6) Você lê o que os outros postam na 5DNet?

Sim, leio os últimos posts e faço comentários, mas ultimamente as crianças e estudantes não tem postado muita coisa no blog, talvez pela dificuldade de escrita e leitura.

Nome: IGCCA

Unidade: Brasília

As perguntas abaixo são um roteiro para que possamos refletir sobre o sentido da 5DNet. Você pode respondê-las uma a uma ou fazer um relato corrido que contemple os diferentes tópicos. Fique a vontade para fazer referência a qualquer tema que não tenha sido contemplado neste roteiro, mas que tenha relação direta ou indireta com a 5DNet.

1) Com que frequência, em que situações e com quais objetivos você usa o 5DNet?

Raramente utilizo a 5DNet. Usei algumas vezes para incrementar meu perfil e adicionar ou aceitar as solicitações de amizade das crianças.

2) Para você, qual a função desta ferramenta dentro da microcultura 5D?

Compartilhar atividades, registrar o que for de interesse pessoal e ao mesmo tempo geral, manter um laço das crianças com os estudantes, com as outras crianças e com as outras unidades do Sarah. O Og@MM participa ativamente, pedindo para as crianças postarem atividades, fotos ou opiniões, mas mesmo assim, não parece surtir muito efeito.

3) Durante o semestre, você mediou a interação de alguma criança na 5DNet? Relate com uma pequena descrição e reflexão.

Sim, o Francisco utilizou a 5DNet (um pouco aleatoriamente), mas depois deixou de lado. O Matheus também utilizou um pouco, primeiro queria fazer seu cadastro, e quando estava pronto, me pediu para que o adicionasse. Em ambos os casos foi muito 
pouco utilizada. O Matheus insistiu muito para que fizéssemos o cadastro dele, e não o vejo usando muito. A 5DNet parece ser no começo desejada porque as outras crianças tem, mas acredito que depois de um tempo, elas não veem muita graça e acabam largando.

4) Relate sua impressão sobre o 5DNet, descrevendo pontos positivos e restritivos.

Acho bom que as crianças tenham acesso a outras atividades e possam deixar suas impressões, compartilhar o que fizeram e ter um contato com outras crianças e estudantes. Ao mesmo tempo, o fato de ela só ser utilizada dentro do espaço do Sarah, pode ser uma dificuldade para quem tem que compartilhar alguma coisa e não está lá no momento.

Nenhuma das crianças com quem me relacionei era fortemente ligada a 5DNet. Não saberia dizer o porquê, uma vez que esse é meu primeiro semestre, e desde o começo do mesmo não percebia uma vontade ou conexão forte das crianças com a ferramenta.

5) Pensando na utilização do 5DNet e em como torna-lo melhor, deixe suas sugestões/análise.

O 5DNet seria melhor utilizado se pudesse ser aberto fora do Sarah. O que dificulta isso é controle do conteúdo das postagens das crianças. Também achei um pouco complicado de mexer (mas nunca fui muito a fundo para descobrir as ferramentas), e o fato de estar dentro do labirinto, acaba tirando um pouco da atenção das crianças.

6) Você lê o que os outros postam na 5DNet?

Sim. Como não sei mexer direito, quando entro no 5DNet, costumo ler as postagens das crianças, não só para tentar entender melhor o que eu deveria postar, mas também porque me desperta a curiosidade, e é uma das únicas coisas que eu consigo fazer.

Nome da estudante: não identificado

Unidade:

As perguntas abaixo são um roteiro para que possamos refletir sobre o sentido da 5DNet. Você pode respondê-las uma a uma ou fazer um relato corrido que contemple os diferentes tópicos. Fique a vontade para fazer referência a qualquer tema que não tenha sido contemplado neste roteiro, mas que tenha relação direta ou indireta com a 5DNet.

1) Com que frequência, em que situações e com quais objetivos você usa o 5DNet?

Semestre passado, como eu chegava antes das 14h, entrava no 5DNet toas as tardes para comentar o blog de todas as crianças, tanto de Brasília quanto do Rio e de São Luiz. Esse semestre, no entanto, como tenho chegado às $14 \mathrm{~h}$ e nem sempre temos tempo de ver o 5DNet, acabei entrando com menor frequência. Quando entro, geralmente com 
alguma criança, que decide entrar para postar alguma coisa ou que entra porque alguém sugeriu que elas vissem alguma coisa no blog.

No meu próprio blog, não tenho entrado muito. No entanto, quando entro, geralmente é para comentar no blog de outras crianças ou postar alguma foto da atividade que fizemos.

2) Para você, qual a função desta ferramenta dentro da microcultura 5D?

Acho que esta ferramenta serve para que as crianças possam se conhecer e se comunicar com as outras crianças da Rede Sarah. Serve também para que elas conheçam novas atividades ao observar o que outras crianças postaram ou mesmo se inspirem para realizar alguma atividade e para trocarmos experiências.

3) Durante o semestre, você mediou a interação de alguma criança na 5DNet? Relate com uma pequena descrição e reflexão.

Lembro-me poucas vezes de ter mediado a interação com alguma criança no 5DNet, esse semestre. A última vez que me lembro de ter utilizado foi na semana passada, com o Matheus. Ele entrou na 5DNet por sugestão da psicóloga Fernanda, do Rio. A psicóloga Fernanda sugeriu que ele entrasse no blog para que pudesse mostrar o blog das crianças do Rio. No entanto, acredito que devido a dificuldade de leitura que ele possui e de manuseio do blog, Matheus entrou rapidamente no blog apenas de uma criança do Rio, viu algumas fotos e logo desistiu e quis fazer outra atividade.

4) Relate sua impressão sobre o 5DNet, descrevendo pontos positivos e restritivos/.

Com relação aos pontos positivos do blog, acho que ele é útil para trocarmos experiências, para conhecermos novas atividades, novas pessoas. Semestre passado, lembro-me de uma criança que postou uma atividade de culinária, e outra criança ao ver o post, decidiu que gostaria de fazer a mesma atividade.

Com relação aos pontos negativos do blog, creio que ele é uma ferramenta de difícil manuseio para as crianças e até mesmo para os estagiários. Além do mais, nunca sabemos quem comentou nossas postagens e não temos acesso à resposta dos comentários que fizemos nas postagens de outras pessoas.

Acredito que inicialmente quem movimentava o blog eram os estagiários. Lembro-me de poucas crianças que utilizavam o blog, e mesmo estas, dificilmente retornavam nos arquivos que postaram para verem os comentários. Desta forma, acredito que os estagiários foram ficando cada vez mais desestimulados, já que nós sempre comentávamos e dificilmente recebíamos resposta. Além do mais, às vezes nós recebíamos a resposta, mas não ficávamos sabendo que havíamos recebido.

5) Pensando na utilização do 5DNet e em como torna-lo melhor, deixe suas sugestões/análise. 
Existe uma grande dificuldade das crianças no manuseio do blog, que desestimulam o uso desta ferramenta. Creio que para melhorá-la deveria ser feita uma formatação do blog, de forma a torna-lo mais atraente e mais dinâmico. Seria interessante se houvesse um espaço de bate-papo no blog, para que pudéssemos conversar com outras pessoas em tempo real.

6) Você lê o que os outros postam na 5DNet?

Sempre que entro no blog leio os posts das outras crianças e comento, tentando fazer uma pergunta que estimule uma resposta.

Nome: não identificado

Unidade:

As perguntas abaixo são um roteiro para que possamos refletir sobre o sentido da 5DNet. Você pode respondê-las uma a uma ou fazer um relato corrido que contemple os diferentes tópicos. Fique a vontade para fazer referência a qualquer tema que não tenha sido contemplado neste roteiro, mas que tenha relação direta ou indireta com a 5DNet.

1) Com que frequência, em que situações e com quais objetivos você usa o 5DNet?

No início da ferramenta a frequência era bem maior, utilizava em todas as tardes do projeto, porém a frequência diminuiu para situações específicas onde eu desejo aproximar as crianças de determinado tema, ou lembrar uma atividade, ou um tema específico que fizemos em uma tarde passada. Ou sugerindo uma atividade realizada com uma criança que deu certo à todas as outras crianças. Um objetivo que deve ser lembrado é a capacidade de comunicação com as crianças, que talvez não tenha sido bem desenvolvido ao longo da ferramenta.

2) Para você, qual a função desta ferramenta dentro da microcultura 5D?

A função dessa ferramenta é a interação das crianças, também como forma de organização da tarde, à medida que ela se espelha nas atividades desenvolvidas por outras crianças, ou por vezes retoma a atividade realizada através da postagem de uma atividade. Enfim, a função de socialização das crianças, acredito ser a função principal da ferramenta.

3) Durante o semestre, você mediou a interação de alguma criança na 5DNet? Relate com uma pequena descrição e reflexão.

Neste semestre, publiquei uma imagem de um trailer de um filme, o que levou outras crianças a procurarem mais sobre este. Também publiquei um jogo interessante, que levou crianças do projeto de quarta e sexta a verificarem o jogo e experimentarem. $\mathrm{O}$ que não foi uma mediação específica, mas um auxílio nas mediações de outros estudantes. 
4) Relate sua impressão sobre o 5DNet, descrevendo pontos positivos e restritivos.

A 5DNet é uma ferramenta que pode auxiliar muito na organização da tarde, na socialização das crianças com elas próprias e nas suas reflexões e nas experiências proporcionadas pela mesma por meio das publicações.

Como pontos positivos podemos citar todos os objetivos que a ferramenta propõe e como ponto negativo podemos verificar a não proximidade das crianças com este tipo de layout, tipo blog, a não possibilidade de eles enviarem mensagens uns para os outros, apenas comentários dos demais, e a falta de treinamento das estudantes, o que prejudicou o bom andamento e que pudessem explorar tudo o que ela tivesse a oferecer de imediato.

Acredito que as estudantes se preocuparam com os demais assuntos referentes ao projeto e abandonaram um pouco o uso desta ferramenta. $\mathrm{O}$ fato também de vários estudantes serem novos no projeto, do não treinamento específico e da dificuldade da realização dos logins, pode ter deixado a ferramenta um pouco de lado. E assim, podemos destacar várias crianças novas que entraram no projeto e também por conta do citado acima não tiveram uma boa aproximação da ferramenta. Como as crianças abandonaram a ferramenta ou por vezes achavam difícil e ficavam impacientes pela dificuldade da realização dos logins as estudantes acabaram deixando a ferramenta um pouco de lado. A não aproximação da maioria das crianças com o layout da ferramenta como um blog, e sim a utilização de demais redes sociais que possuem outro formato pode ter não aproximado como queríamos as crianças desta ferramenta.

5) Pensando na utilização do 5DNet e em como torna-lo melhor, deixe suas sugestões/análise.

Acredito que um ponto principal deve ser o empenho das estudantes a torna-lo uma ferramenta que possa ser um facilitador da tarde, de acordo com os seus objetivos. Outro ponto, que acredito ser um facilitador de aproximação com as crianças pode ser a implementação de um inbox como ferramenta de comunicação entre elas, assim ser um meio de socialização das crianças entre si. O apoio da informática em relação aos logins e senhas, também pode facilitar a aproximação das crianças com as ferramentas.

6) Você lê o que os outros postam na 5DNet?

No início da implantação eu lia todos os posts anteriores ao meu e tentava comentar em todos, após comecei a dar prioridade para os posts de P.C, e alguns de quarta e sexta, onde tínhamos mais assuntos.

Estudante: MOSR

Unidade: Brasília

Roteiro de registro do aluno: 5DNet 
As perguntas abaixo são um roteiro para que possamos refletir sobre o sentido da 5DNet. Você pode responde-las uma a uma ou fazer um relato corrido que comtemple os diferentes tópicos. Fique à vontade para fazer referência a qualquer tema que não tenha sido contemplado neste roteiro, mas que tenha relação direta ou indireta com a 5DNet.

\section{Com que frequência, em que situações e com quais objetivos você usa o 5DNet?}

Usei apenas 3 vezes, Neurocirurgia 5DNet nem tem foto do perfil ainda. Usaria mais se houvesse uma quantidade maior de fotos e coisas para compartilhar. Talvez, também, não faça tanto sentido a ferramenta para manter comunicação com as pessoas da mesma unidade, já que nos vemos todas as terças e quintas e são nesses dias que temos a oportunidade de utilizá-la. Se, por exemplo, pudéssemos utilizar em casa, faria mais sentido. Contudo, poderia ficar um pouco desvirtuado se as crianças postasses coisas de suas vidas fora do Sarah.

\section{Para você, qual a função dessa ferramenta dentro da microcultura 5D?}

Em minha opinião, funciona bem como meio de dialogo entre as unidades. Se alguém faz algo interessante na unidade do Rio, por exemplo, podemos ver as fotos e comentários e tentar fazer algo parecido em Brasília. Além disso, é outra opção de atividade para desenvolver com a criança, compartilhando fotos e coisas que tenham achado legal na tarde. Contudo, desde que cheguei ao projeto, não foi grande o interesse de nenhuma criança em publicar lá. Comentam mais, inclusive, de Facebook, Orkut que do 5DNet.

3. Durante o semestre, você mediou a interação de alguma criança na 5DNet? Relate com uma pequena descrição e reflexão.

Uma vez com o menino Matheus, outra com Geovane. Matheus não havia criado ainda o 5DNet, Geovane estava com problemas para usar o dele. Ajudei Matheus a criar sua conta, mas, depois de vários problemas, o menino se desmotivou. Não conseguimos ativar sua conta. Alias, não entendo porque tem que enviar um e-mail para ativação, poderia ser mais simples. Para Matheus, escrever é muito demorado. Tivemos que escrever e reescrever umas cinco veze o seu nome, sobrenome, e-mail etc até que conseguíssemos, foi bastante cansativo.

\section{Relate sua impressão sobre o 5DNet, descrevendo pontos positivos e restritivos.}

Assim como já falei antes, creio que é uma boa ferramenta para comunicação entre unidades. Pode se ver o que está mais sendo feito e o que tem dado certo em outros lugares para nos espelharmos aqui. Contudo, poucas crianças se sentem interessadas em ver o que as outras unidades estão fazendo, parece servir mais para elas como meio de comunicação com as pessoas da própria unidade. Mas, para se comunicar com as pessoas da própria unidade, podemos simplesmente chegar e falar com a outra pessoa, mostrar uma foto, mostrar um jogo... Não é necessário publicar no 5DNet, o que, para mim, é um dos motivos do desinteresse pela ferramenta. 
Talvez ela tenha sido mais interessante antes por ser uma novidade, principalmente para as crianças. Com o tempo, podem ter percebido que não há tanta utilidade em uma rede relacionamento naquele contexto, principalmente se não se importarem para o que está ocorrendo em outras unidades, com pessoas que não conhece. Com o desinteresse por parte das crianças, fica chato também para nós estudantes.

5. Pensando na utilização do 5DNet, e em como torna-lo melhor, deixe suas sugestões/análise.

Não sou um grande usuário do 5DNet, mas me recordo de um problema: as fotos aparecem apenas em tamanho original, quando a qualidade da máquina é boa as fotos ficam maiores que a tela, impossibilitando de vê-las por completo. Seria bom que as fotos fossem redimensionadas automaticamente ao serem postadas, como acontece no Facebook. Tirando isso, só consigo dizer que seria mais interessante se pudéssemos todos, inclusive as crianças, acessarmos de casa. Contudo, talvez esse não seja o objetivo da ferramenta, talvez ficasse um pouco desvirtuado também.

\section{Você lê o que os outros postam na 5DNet?}

Não tenho o hábito, porém, ultimamente tenho me interessado um pouco mais, planejo começar a utilizar mais a ferramenta no futuro e chamar atenção das crianças para ela.

Nome: NSA

Unidade: Brasília

1. Com que frequência, em que situações e com quais objetivos você usa o 5DNet?

Faço uso da 5DNet para postar arquivos, fotos e vídeos referentes à minha tarde ou sobre hobbies. Os objetivos do uso da 5DNet continuam os mesmos, desde o semestre passado, porém a frequência diminuiu muito.

2. Para você, qual a função dessa ferramenta dentro da microcultura 5D?

A principal função da 5DNet para o projeto consiste em estabelecer mais relações interpessoais, aumentar e aproximar o contato de crianças e estudantes que nunca se viram ou que nunca passaram uma tarde juntas, a partir de seus interesses e curiosidades.

3. Durante o semestre, você mediou a interação de alguma criança na 5DNet? Relate com uma pequena descrição e reflexão.

Ao final de uma tarde com a Laura, ela me guiou para o computador e entrou na 5DNet. Primeiramente, ela abriu alguns arquivos que postou, ia mostrando as fotos das pessoas que haviam comentado. Eu lia para ela os comentários, perguntava se ela já havia respondido e a incentivava a responder. Depois, ela ficou clicando nas fotos de pessoas conhecidas e fazia o nome dela em libras ou utilizando a prancha de comunicação. Fico 
refletindo qual será a função da ferramenta para Laura e a impressão que tenho é de ser um espaço que ela possa guardar todos os amigos dela e acessá-los quando quiser, e não em um sentido de se comunicar com os outros.

4. Relate sua impressão sobre o 5DNet, descrevendo pontos positivos e restritivos.

Um ponto positivo da 5DNet, certamente, é permitir o contato com outros participantes de outras 5Ds e estreitar vínculos com as crianças do grupo, pois o modelo de formação de díade dificulta que tenhamos muito contato com nenhuma delas. Um ponto negativo 'a dificuldade para voltar a diálogos anteriores, por exemplo, se eu comentei muitos arquivos de vários amigos em um dia, no outro se quiser voltar em um deles é difícil lembrar qual foi, a não ser que volte um por um.

Penso que se enfraqueceu porque semestre passado foi um movimento muito forçado pela maioria dos estudantes, mesmo que a criança não apresentasse interesse em utilizála. Também por ser difícil estabelecer diálogos mais longos, pelo que foi citado como um ponto negativo, então, o uso era de rápida duração e sempre com os mesmos objetivos, não contendo novidades.

5. Pensando na utilização do 5DNet, e em como torna-lo melhor, deixe suas sugestões/análise.

Seria legal testar a inserção de um bate-papo, criando vínculos mais estáveis por meio de conversas privadas, possibilitando vários tipos de assuntos. As crianças se sentiriam mais à vontade para expressar suas curiosidades e interesses a outras pessoas.

6. Você lê o que os outros postam na 5DNet? (pergunta ao Lucas)

O Lucas não respondeu, apesar de eu ter perguntado mais de uma vez. Levei-o para um computador, abrimos o 5DNet dele e pedi para ele me mostrar o que ele geralmente fazia. Abri um arquivo de um amigo dele e mostrei os comentários, perguntei se ele já havia escrito para alguém, como os outros amigos faziam e o Lucas não respondeu novamente.

Estudante: RSB

Unidade: Brasília

1. Com que frequência, em que situações e com quais objetivos você usa o 5DNet?

Demorei um pouco par criar meu perfil no 5DNet e usei ele muito pouco, apenas para comentar algumas postagens. Não a usei a fim de registrar alguma atividade que fiz, então, por esse motivo, minha página não recebeu tantos acessos. Eu tinha um pouco de receio por não saber usar muito bem e não sabia ao certo como explorar e em que 
situações aproveitar. Por eu não saber explorar essa ferramenta, eu também não sabia despertar o interesse da criança para com ela.

2. Para você, qual a função dessa ferramenta dentro da microcultura 5D?

Ele possibilita a relação entre as crianças e os estudantes, tanto dentro da nossa unidade quanto desta com as outras. São muitos os meios de usar tal ferramenta, porém vejo mais claramente sua importância, por exemplo, na sua função de possibilitar uma interação a partir de interesse em comum, o que seria muito eficaz para aproximar um integrante dessa microcultura de outro que dela participa.

3. Durante o semestre, você mediou a interação de alguma criança na 5DNet? Relate com uma pequena descrição e reflexão.

A minha única mediação nessa situação foi em uma tríade. Érika recentemente trouxe algumas fotos de seu desfile e queria que as visse. Usamos o 5DNet para tal finalidade. Vejo que Érika é uma das crianças que têm usado a ferramenta com bastante frequência.

4. Relate sua impressão sobre o 5DNet, descrevendo pontos positivos e restritivos.

Sua proposta de permitir a troca de experiências entre os atuantes da microcultura da 5D é muito rica, principalmente pré-operatório abranger também essas relações dentro de outras culturas no Brasil. Creio que, por exemplo ter um formato diferente, dificulta um pouco o entendimento da proposta e de como se dá a comunicação dentro da pagina. Eu encontrei dificuldades em, por exemplo, encontrar registro de atividades passadas de outras pessoas quando estas me recomendavam.

Talvez porque as formas de interação e as problemáticas das tardes se voltaram para outras ferramentas e outras questões. Frente a preocupações como as formas de comunicação da Laura e do Francisco, implementação da sugestão de acordos, dentre outros, essa ferramenta talvez não tenha ganhado tanto destaque. Por ser nova, creio que ela precisaria de uma maior atenção. Algumas crianças também demoraram a ter seus perfis criados e algumas tinham dificuldades em lembrar a senha.

5. Pensando na utilização do 5DNet, e em como torna-lo melhor, deixe suas sugestões/análise.

Acho que essa ferramenta está com seu uso enfraquecido não tanto pela sua função, mas pela sua estrutura. Creio que esta é de difícil manuseio no sentido de não estarem claras todas as formas de interação que essa ferramenta possui. Seu layout poderia ter um formato mais acessível e simplificado, semelhante ao das grandes redes sociais.

6. Você lê o que os outros postam na 5DNet? (pergunta ao Lucas)

Eu não costumo ler todos os dias que venho ao Sarah, ou seja, não é uma rotina préestabelecida ler as atualizações no 5DNet. Quando algum estudante sinaliza, na reunião das 14 horas, que alguma criança postou algo, eu leio e comento. Ultimamente, eu não estou lendo, acompanhava mais quando eu estava no começo do projeto. Creio que eu não incorporei essa ferramenta na minha rotina da 5DNet. 
Estudante - não identificado

O 5DNet é uma ferramenta que uso para a comunicação com as outras unidades do Sarah, com o pessoal do Quinta Dimensão, tanto estudantes quanto crianças. Através dele podemos postar fotos, vídeos, músicas, textos, sugestões de atividades, dentre outras coisa, com o objetivo de enriquecer as tardes no projeto.

Da mesma forma em que existem crianças que preferem brincar de boneca, ou jogar vídeo game, há as que gostam de usar o $5 \mathrm{DNet}$ e as que não gostam. A Érika é um exemplo de quem se sente muito bem usando essa ferramenta. Ela, além de postar fotos de receitas que ela gosta, espera comentários de todos e os responde. Apear de sua dificuldade com a leitura e escrita e também de sua timidez, Érika "se solta" na 5DNet e é ativa e socializa com todos.

Em relação ao uso do 5DNet ter enfraquecido esse semestre, acredito que as crianças novas no projeto estão se acostumando com a ferramenta, e aos poucos irão usá-la com mais frequência.

Costumo ler os arquivos mais atuais, aqueles que foram postados por último por todos os usuários da 5DNet. Antes, havia um pouco mais de investimento no blog por parte dos estudantes, já que acredito que a maioria das crianças não compreende o sentido de se ter um blog, ou às vezes nem sabe o que postar. Agora, o foco está mais em postar fotos e a parte textual do post está bem menor. As crianças que escrevem mais normalmente falam sobre suas tardes e sobre novelas, filmes.

A ferramenta é importante para a comunicação entre todos do projeto, auxilia no planejamento da tarde, pois lá as crianças postam coisas que se interessam e isso pode direcionar o estudante no momento da interação e também formar vínculos, tanto com criança com estudante quanto criança com criança.

Com relação à minha experiência com a ferramenta, não observei pontos negativos.

Estudante: ALSH

Unidade: Rio de Janeiro

1- Bom, se a pergunta for em relação a entrar no meu login, a frequência é regular (devido a algumas vezes o tempo escasso) com o principal objetivo de comentar no post dos outros usuários, algumas vezes postar uma foto sobre a tarde anterior. Houve uma vez, porém, que eu entrei no meu login durante uma interação, para ver se estimulava a criança a entrar no seu próprio login. Em relação à frequência que entro com as crianças já é bem diferente, chega a ser bem. Os adjetivos das crianças também variam, sendo algumas que entram só para ver o que está sendo postado, outras entram simplesmente para postar e outras entram para ver seus comentários. As situações também variam, algumas vezes, começamos a tarde e a criança não demonstra nenhum interesse e, ao longo da tarde, surge alguma coisa foto/vídeo/história) que incentiva o menino a ir postar. 
2- Para mim, o 5DNet tem como função a interação dos projetos, Rio/São Luis/Brasília. Dessa forma, as crianças percebem que a nossa microcultura também existe em outros lugares do Brasil, o que acaba dando uma "reforçada" na crença dessas crianças. Outro ponto importante que considero é a forma como o blog ajuda as crianças em sua metacognição na hora da postagem, em que a criança/adolescente tem que repensar no que foi feito durante a tarde para que a postagem faça algum sentido.

3- Houve uma vez em particular que o uso do 5DNet foi bem marcante, eu e um menino aqui do Rio estávamos em uma sala onde tem desafios sobre conhecer o mundo. Enquanto estávamos em uma atividade de tabuleiro, misturada com o globo e conhecendo vários lugares diferentes que tive a luz de postarmos no blog alguma coisa sobre esses lugares. Enquanto fazíamos nossa postagem, eu perguntei a ele se sabia que o nosso projeto também existia em alguns outros estados do Brasil, ele disse que não sabia e, sendo assim, ficamos no blog por algum tempo, olhando as crianças e estudantes de outros estados. Ele ia me fazendo perguntas sobre as semelhanças entre os projetos, sobre as atividades e se ele poderia mandar mensagem para qualquer pessoa, e eu fui respondendo. Essa interação me marcou, pois foi significativa em relação ao 5DNet, ele surgiu na tarde de forma casual, sem pressão e foi uma ferramenta bem interessante. Ela cumpriu sua função de integrar os projetos, além de ajudar o menino a repensar sobre a atividade que havíamos terminado.

4- Sempre que eu entro, tento ler tudo o que aconteceu nos dias anteriores, porém no último semestre, as postagens diminuíram bastante, sendo assim, não tem tanta coisa para ler. Tento me focar mais nas postagens das crianças e acaba que sempre me foco nas crianças aqui no Rio, pois, dessa forma, conseguimos estimular a entrada posteriormente.

Minha impressão sobre o blog é que é um pouco confuso e complicado, a demora para postar uma foto (tendo que colocar em arquivo, para depois poder colocar no blog), a falta de uma notificação mais chamativa para a criança ver que seu post foi comentado e a forma como ele é "montado" (ficando tudo em uma mesma pagina e com as mesmas cores) são pontos que eu destaco como negativo. Os pontos positivos eu diria que são o fato de você poder "seguir" quem quiser, mesmo que a pessoa não te siga de volta, os comentários só bem organizados (mostrando o dia, a foto e o nome da pessoa que escreveu), além, é claro, de o perfil ser completo (onde mostra tudo sobre as crianças).

5- Acredito que as dificuldades relatadas anteriormente podem ser o principal fator para esse enfraquecimento, pois, dessa forma, as crianças/estudantes vêm postando cada vez menos, logo, não tem amis o que se ver, levando a perda do interesse pela ferramenta. Uma observação que fiz é que parece que as crianças daqui do Rio têm postado mais e entrado mais também, então, quando elas entram buscando as crianças de outros estados, não têm o que ver. Acho também que muitas crianças deixam de usar o blog por "falta de tempo", pois, se eles ficarem no blog, terão menos tempo para brincar.

6- Acho que se for possível deixar o site um pouco mais atraente para que dessa forma a criança não tenha a impressão de estar perdendo tempo, pode ser um ponto a ser trabalhado. As sugestões que já demos em várias reuniões acredito que podem fazer a diferença para mudar essa situação de enfraquecimento. Acho que a principal dificuldade que tem que ser melhorada e a situação da postagem de fotos. 
Estudante: AISM

Unidade: Rio de Janeiro

1. Com que frequência, em que situações e com quais objetivos você usa o 5DNet?

Tento utilizar o 5DNet nas interações com as crianças para postar fotos de atividades que são realizadas na tarde e que vejo que a criança está gostando muito, ou quando entro em meu 5DNet e vejo um post de alguma atividade que interessa à criança, tento incentivar que a criança entre em seu 5DNet para dar uma olhada. Porém nem sempre consigo entrar com as crianças. Isso se dá devido ao tempo, às vezes a criança não quer entrar. Então, geralmente entro mais para comentar posts que realizo com as crianças, ou dar uma olhada no que as outras crianças estão fazendo nas outras unidades.

2. Para você, qual a função dessa ferramenta dentro da microcultura 5D?

Acredito que esta ferramenta tem diferentes funções, essas variam de acordo com cada usuário da rede. Para algumas crianças essa ferramenta serve para ajudá-las na metacognição. Para outros, o 5DNet auxilia na comunicação com os demais usuários, possibilitando que haja uma interação com pessoas das outras unidades.

3. Durante o semestre, você mediou a interação de alguma criança na 5DNet? Relate com uma pequena descrição e reflexão.

Neste semestre, não me recordo de ter mediado com sucesso a interação entre uma criança e o 5DNet, mas no semestre passado houve uma tarde em que a criança comentou que gostava de ver fofocas no Orkut, então, através desse sue interesse em saber o que as outras pessoas estão fazendo, apresentei o 5DNet e ele começou a utilizálo com mais frequência. Algumas crianças entram automaticamente em seu 5DNet sem precisar de nosso incentivo, outras, mesmo conversando, não conseguimos despertar o interesse, por mais que tenhamos feito uma atividade muito legal.

4. Você lê o que os outros postam na 5DNet?

Tento ler os posts no horário de $14 \mathrm{~h}$ às $15 \mathrm{~h}$, mas às vezes os temas das reuniões levam o horário todo, nesse tempo também respondemos as mensagens do $\mathrm{Og} @ \mathrm{MM}$ e acabo vendo com as crianças durante a interação.

5. Relate sua impressão sobre o 5DNet, descrevendo pontos positivos e restritivos.

Acredito que o 5DNet é uma ferramenta importante na microcultura, pois, através dele algumas crianças conseguem lembrar-se do que fizeram nas últimas interações, postam compartilhando com as outras crianças atividades que fizeram e gostaram, interagem uns com os outros através dos comentários dos posts. Por outro lado, o manuseio dessa ferramenta é um pouco complicado e demorado, com isso, algumas crianças evitam utilizá-lo para brincar mais. 
Como já comentei em alguns diários, percebi que as crianças que entraram neste semestre, aqui no Rio, utilizam mais essa ferramenta, além de comentar com as outras crianças e estudantes o que postaram e pedem para que comentem. Acredito que, como há uma mudança dos integrantes da 5D a cada semestre, uma das possibilidades para esse enfraquecimento possa ser que os usuários dessa rede não utilizem muito redes de relacionamento. Outra possibilidade pode ser que as crianças não tenham muito interesse em mostrar o que estão fazendo para pessoas que não conhecem. Como é demorado postar uma foto, algumas crianças preferem brincar, ou somente verem o que as outras pessoas postam. Ou, às vezes, falta algo que os motivem a postar no 5DNet, pois algumas pessoas, assim como eu, preferimos ver o que os outros postam e comentam e não gostamos muito de postar. Às vezes, falta melhor planejamento do tempo com as crianças, pois às vezes até surge algo que motiva as crianças a postarem no 5DNet, mas não, devido ao tempo, acabam não postando.

6. Pensando na utilização do 5DNet, e em como torna-lo melhor, deixe suas sugestões/análise.

Acredito que o layout é algo que pode ser mudado para chamar mais atenção das crianças e a facilidade em comentar, postar fotos e visualização dos comentários e posts ajudaria a motivar o uso dessa ferramenta. Como já conversamos em algumas reuniões, a questão do tempo pode ser resolvida com o planejamento no início da interação com a criança. E os estudantes incentivarem o uso da ferramenta de acordo com o momento, pois às vezes, durante a tarde, não fazemos atividades que motivem um post, mas podemos incentivar as crianças a pelo menos darem uma olhada no que as outras crianças estão fazendo nas outras unidades.

Estudante: BGR

Unidade: Rio de Janeiro

1. Entro no 5DNet muito pouco com as crianças. Às vezes, por não dar tempo durante a tarde, outras porque a criança não quer (nesse caso, entro no meu para que ela possa sentir vontade de entrar, de vez em quando funciona). Faço uso do blog com a criança em diferentes situações, tais como: no início ou no fim da tarde, para postar fotos ou vídeos, para olhar ou comentar o blog de outras pessoas, com o objetivo de registrar o que a criança fez, usar como estratégia de memorização (como no caso do Nilson), interagir com outras crianças e/ou estagiárias (o que acontece muito pouco). Agora, refletindo sobre minha utilização do meu 5DNet, também uso pouco, entro para olhar as postagens mais recentes, algumas eu comento, outras só olho, de vez quando também posto algumas fotos da interação. Normalmente, uso antes do horário das crianças; mas também em alguns momentos de algumas interações, durante a tarde. Com o objetivo de estimulá-los a entrar para ver os comentários e responder, interagindo não só comigo, mas com todos. 
2. O 5DNet é uma ferramenta que auxilia na metacognição da criança, porque depois de postar uma foto ou vídeo, ou até mesmo comentar no próprio post ou no de outros, a criança pode pensar sobre o que fez, se foi bom ou ruim, com quem estava e da forma como jogou (se criou novas regras ou não). Diante disso, pode dar dicas, dizer onde se pode encontrar essa atividade no labirinto, quais materiais usou ou até mesmo em que vídeo game se joga. Podendo, dessa forma, pensar sobre o que foi feito e todas as etapas que foram cumpridas para se chegar ao objetivo final e disso tirar uma conclusão da atividade, pensando no planejamento desta, e se for o caso de comentar, o blog auxilia na organização do pensamento para estruturar a resposta e também colabora com a memória, pois faz a criança relembrar o que passou na tarde anterior.

3. Sim. Durante o período, tive três momentos que acho significativo com o uso do $5 \mathrm{DNet}$. Um deles foi com o Henrique, fizemos uma música sobre a 5D, e ao terminarmos essa atividade ele queria muito postar o vídeo, mas, como o tempo era curto e a conversão de vídeo é demorada, postarmos somente uma foto com a letra. Outro momento foi com a Cecília, que tem uma resistência em relação ao blog. Tiramos muitas fotos e, após a atividade, sugerimos que ela colocasse no 5Dnet. Ela aceitou e quis colocar várias fotos, pois ela disse que queria muito postar as fotos. E a última foi com o Flamel, ele chegou à 5D dizendo que não queria entrar no blog, pois queria brincar e não queria perder tempo entrando no 5DNet, mas, depois de algumas tentativas e de um pouco de conversa, ele entrou e ficou a tarde toda no planejamento de uma atividade, que foi pensada por ele, mas ao postar pedindo sugestões, elaborou a atividade com base nos comentários do 5DNet (selar a amizade). Esses três momentos foram bem interessantes e cada um teve sua peculiaridade. Em dois momentos houve a vontade da criança de postar e mostrar para todos o que tinha feito e no outro não, pois o menino julga que perde tempo entrando no 5DNet, fato que nos faz pensar sobre quão o conceito que eles têm do blog e qual o interesse que têm nele.

\section{Sim, quando o assunto me interessa eu leio e comento.}

5. O 5DNet é bacana, pois nele podemos ter contato com as pessoas de Brasília e de São Luis (ainda que tenha a rede diminuído em comparação com o semestre passado), postar fotos e vídeos, comentar outros blogs e receber comentários, achar alguma atividade em comum que uma criança tenha feito nas outras 5Ds e descobrir atividades que existem no labirinto, que nem sabíamos que existiam. Essa interação é bem interessante, porém acho que está sendo dificultada pela forma como o 5DNet está posto. Pelo seu aspecto visual, que não se torna tão atrativo, pela forma de manuseamento, no sentido que quando se está vendo as últimas postagens e quer ver uma com mais detalhes, no momento em que se deseja voltar para a página e continuar vendo todas as postagens tem-se um trabalho enorme, pois é necessário clicar em várias "palavras" para que se chegue ao ponto de partida, é ainda mais trabalhoso se estiver em uma página avançada, porque é necessário passar página por pagina, ou seja, não tem como voltar com facilidade para a página que se encontrava (como é possível apertando a seta ou ícone "voltar" em páginas da Internet ou no próprio sistema do computador); a dificuldade de converter um vídeo para postar também é um ponto negativo, algumas crianças desistem de postar, pelo trabalho que dá. No caso do vídeo, o principal trabalho é convertê-lo e ainda tem muitas pessoas que não dominam essa etapa, o que dificulta mais a postagem e também é difícil uma foto; é mais simples que o vídeo, mas ainda assim é complicado. 
No Rio, não percebemos muito esse enfraquecimento da rede, pois estamos sempre postando. Mas, comparando com o semestre passado, percebo que as outras unidades, que eram tão participativas no blog, estão diminuindo a frequência das postagens e até mesmo dos comentários. Mas, acredito que o 5DNet esteja se enfraquecendo pelos motivos que citei acima, e por também, muitas vezes, não se ter retorno, ou seja, a pessoa posta e ninguém comenta. Já aconteceram algumas vezes comigo e fiquei um pouco desmotivada para entrar e postar no blog. Imagino que aconteça a mesma coisa com a criança, é um retorno esperado por elas, pois se ninguém comenta, pode ser que ninguém tenha visto (não necessariamente, pois alguns meninos aqui no Rio, entram sempre no 5DNet, mas só para olhar, não postam e nem comentam), o que faz com que a vontade e a frequência das postagens diminuam. Acredito também que o blog tenha tido um "boom" no semestre passado por ser novidade, mas agora, por ter alguns pontos que dificultam a navegação e a falta de retorno, faz com que as pessoas percam o interesse nele. Pode ser que esteja errada, mas penso que isso pode ser um motivo para o enfraquecimento da rede.

6. Penso que para haver uma maior adesão ao 5DNet, ele tem que ser mais atrativo visual e mecanicamente. Acredito que seja importante que ele seja mais simples de usar, para que seja rápido de aprender, pois não temos tanto tempo para usá-lo e quanto maior a dificuldade menos as pessoas usam, ou mesmo que seja difícil, mas se tem tempo e se tem interesse naquela ferramenta é mais fácil de aprender. Seria interessante que pudesse ter em um canto a sinalização das pessoas que estão on-line, aí, não sei se seria bacana ter um bate-papo. Mas, se todos puderem saber quem está on-line seria legal. Pelo fato de ter pessoas que entram e somente olham. Isso seria um sinalizador de que a pessoa também participa do blog, porém de uma forma pouco diferente. Também acho que poderia ter uma pequena parte da pagina principal que dissesse tudo o que as pessoas estão fazendo. Por exemplo, se alguém de Brasília comentou a foto de uma pessoa de São Luis, todos podem ver que essa pessoa comentou. De repente, pode atrair a atenção da criança ou das estagiárias, para ver ou para comentar. Dessa forma, acredito que ele possa se tornar mais dinâmico.

Nome: FLO

Unidade: Rio de Janeiro

As perguntas abaixo são um roteiro para que possamos refletir sobre o sentido da 5DNet. Você pode respondê-las uma a uma ou fazer um relato corrido que contemple os diferentes tópicos. Fique a vontade para fazer referência a qualquer tema que não tenha sido contemplado neste roteiro, mas que tenha relação direta ou indireta com a 5DNet.

1) Com que frequência, em que situações e com quais objetivos você usa o 5DNet?

Costumo entrar antes da reunião inicial (de duas horas) para poder comentar as fotos e vídeos das outras crianças e também para atualizar a minha página, já que dificilmente é possível durante a interação, tendo em vista que não sobra muito tempo. Tento fazer 
essa rotina sempre que possível, porém não é todo dia que consigo atualizar. Além disso, uso o 5DNet durante as interações, mas nesse caso, geralmente com login da criança. Esse manuseio depende muito da criança que está formando a díade, pois temos objetivos diferentes com cada uma. Por exemplo, um adolescente da unidade do Rio entra sempre (todo dia) no início da interação, pois tem dificuldade de memória e a ferramenta o auxilia a recordar, já que sempre postamos uma foto da tarde. Também temos as crianças que geralmente entram no final da tarde, pois restam dez minutos e preferem navegar e iniciar uma nova atividade. Existem também aquelas que costumam entrar para ler os comentários, olhar as fotos, mas não gostam de postar. Por fim, faço uso da ferramenta quando estou em situação conflituosa com a criança, pois já tive experiências em que não conseguíamos chegar a comum acordo sobre a atividade a ser realizada e, por isso, acabávamos entrando no 5DNet. Portanto, acredito que os objetivos se adequam de acordo com a necessidade da díade e do momento da tarde.

\section{2) Para você, qual a função desta ferramenta dentro da microcultura 5D?}

Acredito que o 5DNet faça parte da nossa microcultura por meio de dois objetivos distintos, porém que se entrelaçam. O primeiro deles é que a ferramenta transforma a microcultura em "macro", possibilitando que as crianças e estudantes percebam que o 5D vai além da sua unidade. Por esse motivo, há uma troca de experiências e conhecimento que vai de encontro com as atividades realizadas nas outras unidades, fortalecendo o conceito de rede. A segunda função/objetivo está relacionada com a mediação colaborativa, já que a ferramenta auxiliar durante a interação, fazendo parte dos desafios e propondo tarefas que estão relacionadas diretamente com o labirinto. Além disso, penso que o 5DNet pode auxiliar nas funções executivas, como a memória, atenção, metacognição, o que contribui com os objetivos mais amplos do projeto.

3) Durante o semestre, você mediou a interação de alguma criança na 5DNet? Relate com uma pequena descrição e reflexão.

Ao longo do semestre, mediei diferentes interações fazendo uso da ferramenta e acredito que quase sempre entramos no blog, mesmo não postando nada. A mais recente foi com a Cecília, 12 anos, que não costuma postar muito no blog e que tem certa aversão pelo Og@MM. Passamos a tarde jogando Esporte X, na parte externa e no fim do dia resolvi tirar fotos da menina enquanto jogava e se alongava. Assim que terminamos a atividade, voltamos ao labirinto para desligarmos o computador, porém ela sugeriu que olhássemos as fotos tiradas e, como gostou muito, ela mesma deu a ideia de colocarmos no 5DNet. Apesar do tempo curto, colocamos quatro fotos, já que a oportunidade não surgia sempre com ela. Assim que acabamos, ela falou que na tarde seguinte gostaria de voltar para postar um vídeo. Achei essa situação interessante por se tratar de uma criança que não tem costume de entrar no 5DNet e que, às vezes, até reclama.

Esse dia me fez refletir que mesmo sabendo que algumas crianças não se identificaram tanto com a ferramenta é interessante tentar estimular e relacionar com tardes que ela tenha gostado, criando uma estratégia que relacione o 5DNet com dias e tarefas boas. Mesmo sabendo que realmente não são todas que gostam, entram e que talvez essa situação tenha sido inusitada, acho válido continuarmos tentando e elaborando novas formas de utilizar a ferramenta. 
4) Relate sua impressão sobre o 5DNet, descrevendo pontos positivos e restritivos.

Acredito que a ferramenta tenha um papel importante dentro da microcultura, porém ainda não se encaixou da forma que gostaríamos, por conta da estrutura e também do interesse dos estudantes e das crianças. Os pontos positivos que percebo estão relacionados à função/objetivo, por exemplo, acho importante para criança sustentar a atenção enquanto está no blog, assim como utilizar da metacognição ao reler algum post ou observar uma foto já postada. Além disso, acho que é interessante ter mais um recurso que possa contribuir com o labirinto, pois os que já estão há um ano no projeto, tendem a desmotivar com as mesmas tarefas e atividades. Mas, observo que esses pontos positivos, muitas vezes, não são percebidos pelas crianças, que só veem no blog uma oportunidade de divulgar fotos e vídeos e também de comentar e receber comentários. Acredito que o objetivo de rede, acaba se perdendo, pois essa troca não é "consciente". As crianças sabem que através do 5DNet podem conhecer e explorar as páginas das crianças de outras unidades, porém não faz tanta diferença no momento de usufruir, pois dificilmente procuram o outro, focalizando suas atividades na sua própria página.

Apesar de saber que a rede de relacionamento está enfraquecendo-se, acredito que não percebemos essa queda de forma muito evidente na unidade do Rio de Janeiro, pois como recebemos muitas crianças novas no último semestre, essas já entram como uma "ajuda maior", pois nós (estudantes) já havíamos aprendido a manusear um pouco melhor a ferramenta. Também observo que as crianças mais novatas, costumam entrar com maior frequência que as antigas, ou seja, penso que essa diminuição no uso se dê, principalmente, pela estrutura da ferramenta que não permite que se entre na página de outros facilmente, além disso, quando vamos postar, necessitamos um tempo maior para entrar em blog/arquivo (ainda não sei muito bem a diferença), incorporar a imagem, escrever o título e por fim postar. Além disso, para ver todos os blogs da rede, é preciso clicar no item "blog", depois em "todos os blogs da rede" para achar a lista completa. Apesar de parecer simples é um caminho longo para a mediação colaborativa, pois acontece que muitas vezes não estamos com tempo sobrando e as crianças acabam perdendo a paciência em aprender a mexer sozinhas e, por isso, acabamos indicando como se deve fazer. Acho que outro fator que pode acabar desestimulando é a falta de comentários e fotos novas, pois como a criança não vê muito fluxo, ela acaba acomodando-se. No entanto, ainda assim, temos tentado estimular que elas postem e depois voltem para responder os comentários. Finalizando, acredito que o insucesso pode estar também relacionado aos diferentes objetivos e funções, o que faz com que os próprios estudantes não entendam e por isso não ratifiquem a importância da ferramenta.

Pessoalmente, acredito que a minha motivação e interesse se deu de forma crescente, pois, aos poucos, consegui entender a funcionalidade para o desenvolvimento da criança e da microcultura. Além disso, acredito que os objetivos ainda estão centrados no individual e, portanto, o conceito de rede ainda não se estabeleceu por completo e é capaz de não se estabelecer, pois tenho dúvidas se as crianças conseguem entender a subjetividade de escrever para um colega que não conhece e não sabe onde vive. 
5) Pensando na utilização do 5DNet e em como torna-lo melhor, deixe suas sugestões/análise.

Acredito que uma sugestão esteja relacionada ao formato, talvez se o blog fosse um pouco mais dinâmico e atrativo, as crianças pudessem se interessar mais (até porque precisa ser chamativo, tendo em vista que acaba "competindo" com os jogos e atividades). Inclusive, em alguns momentos, eu mesma sinto dificuldade de mexer, pois você só recebe informações dos amigos e para olhar os que não são, o trajeto é mais longo, o que acaba por desmotivar. Além disso, acho interessante que se estabeleça um debate/discussão sobre a ferramenta com os estudantes, pois se compreenderem a importância da mesma podem usufruir e flexibilizar melhor com a díade. Por fim, acho importante ratificar e esclarecer que nem todos irão utilizar e se interessar da mesma maneira. Evidentemente, o diálogo é muito bem vindo, porém tanto os estudantes quanto as crianças tem diferentes interesses e preferências dentro da microcultura e por isso se apegam mais a algumas ferramentas do que outras, tal qual com o Og@MM.

6) Você lê o que os outros postam na 5DNet?

Não é sempre que consigo ler e entrar no 5DNet para poder atualizar e responder. Muitas vezes pela falta de tempo durante a interação, mas também porque não acho a ferramenta muito prática. Principalmente no início, entrava e muitas vezes não achava os "posts" mais recentes. Ainda hoje tenho dificuldade para manusear.

Nome: IRS

Unidade: Rio de Janeiro

Roteiro de registro do aluno: 5D-NET

1. Com que frequência, em que situações e com quais objetivos você usa o 5D-NET?

Tento usar o 5D-NET em quase todas as interações. Geralmente uso quando no desafio é pedido, quando a criança sinaliza a vontade ou depois de uma atividade que foi interessante sugiro a criança. Ou até mesmo quando começa a tarde com a criança, sugiro que olhe para ver o que as outras crianças estão fazendo e os comentários das fotos. Mas muitas vezes algumas crianças não querem entrar se não for para postar ou ver o comentário em sua foto. Uso como forma de mediação e às vezes para auxiliar alguma criança com a memória, pois no 5D-NET podemos postar foto da tarde. O que auxilia a criança com problema de memória a lembrar o que fez na tarde anterior.

2. Para você, qual a função desta ferramenta dentro da microcultura 5D?

O 5D-NET tem como função, fazer com que as crianças possam interagir com outras crianças. Não só com as crianças que estão perto delas, como com outras crianças do projeto, porém de outros estados. Por meio das atividades feitas no labirinto e postadas no 5D-NET, criando um assunto comum entre as crianças da 5D mesmo que sejam de outro estado. 
3. Durante o semestre, você mediou a interação de alguma criança na 5D-NET? Relate com uma pequena descrição e reflexão.

Sim, com o Nilson. Que é uma criança que tem problema de memória e percebemos que tinha uma memória visual um pouco melhor. Então nós estagiárias, e a equipe combinamos que sempre no final da tarde iriamos tirar uma foto da tarde e ele postaria no 5D-NET com uma legenda. Para que na próxima tarde, ele pudesse ver, ajudando a lembrar do que ele tinha feito na tarde anterior. Cada estudante que ficasse com ele na tarde o lembraria de entrar no 5D-NET antes de ir fazer uma atividade e no fim. O 5DNET, foi um ótimo recurso para auxilia-lo e ele foi bem receptivo com a ideia, pois nunca se opõem a entrar.

\section{Você lê o que os outros postam na 5D-NET?}

Às vezes. As crianças do Rio de Janeiro, eu leio mais. Até porque às vezes alguma criança pede para que eu olhe o 5D-NET dela, ou até mesmo para estimulá-la a olhar o 5D-NET quando eu digo que vi e comentei no dela. Mas já, com o 5D-NET de outras crianças do outro estado, só olho e comento quando nas atualizações aparecem e me interessa. Mas confesso que não vejo o 5D-NET de outras crianças de outro estado se não aparecem nas postagens mais recentes.

5. Relate sua impressão sobre o 5D-NET, descrevendo os pontos positivos e restritivos.

O 5D-NET como eu já relatei em outra pergunta é um ótima ferramenta para que as crianças possam interagir com outras, auxiliam na memória...Porém ele não é muito atrativo, pela dificuldade de postar fotos, postar no blog, ver as postagens do blog de outros. Além das últimas postagens não comportarem muitas atualizações, limitando a visualização. E eu acredito que num primeiro momento o que traz o interesse para ver, é as atualizações, e essas são muito limitadas.

Acredito que seja porque o 5D-NET é difícil e não atrativo, pelos motivos que respondi na pergunta anterior. No começo do 5D-NET as crianças ainda tinham um interesse porque era novidade. Depois que conheceram, as que gostaram continuaram usando e as que não param ou diminuíram seu uso. Além disso, acredito que para as crianças seja uma perda de tempo ficar no 5D-NET, enquanto poderiam estar brincando. Creio que isso seja um fator importante para esse enfraquecimento.

6. Pensando na utilização do 5D-NET e em como torna-lo melhor, deixe suas sugestões/análises.

Para que ocorra um maior interesse das crianças com o 5D-NET, penso que tem de haver uma maior praticidade em postar fotos e no blog, sendo a mudança mais importante. Porque muitas crianças acabam desistindo de postar pela dificuldade. Tem de haver um chat para que as crianças possam conversar com as outras de estados diferentes, para que haja uma melhor ligação entre todas as crianças e estudantes do projeto. Deve haver uma maior amostra de atualizações mostrada na página principal do 5D-NET. Também sugiro que tenha no 5D-NET o ranking dos jogos mais jogados no labirinto, creio que isso também possa interessar mais as crianças a entrarem no mesmo. 
Nome: JMFS

Unidade: Rio de Janeiro

1. Com que frequência, em que situações e com quais objetivos você usa o 5D-NET?

Costumo acessar minha conta antes de iniciar a tarde de interação com as crianças e durante alguma interação. Quando acesso antes de começar a tarde, tenho o objetivo de responder alguns comentários, comentar algumas postagens ou postar algo para manter uma relação com as crianças na rede. Ao acessar minha conta no momento de uma interação, meu maior objetivo é mostrar meu interesse na rede para despertar o mesmo na criança.

2. Para você, qual a função desta ferramenta dentro da microcultura 5D?

Acredito que a maior função do 5D-NET dentro do projeto é promover a interação entre as crianças de estados diferentes. No decorrer do semestre fomos descobrindo que ele pode ter outras funções, como ajudar uma adolescente com dificuldades de memória.

3. Durante o semestre, você mediou a interação de alguma criança na 5D-NET? Relate com uma pequena descrição e reflexão.

No decorrer dos dois semestre, tive oportunidade de lidar com crianças que gostavam muito, umas que somente entravam para olhar perfis e outras que não gostavam nem de entrar. Uma criança me chamou atenção por seu grande interesse na ferramenta. No início da tarde, o menino se aproximou de mim para perguntar se eu tinha um perfil no 5D-NET e que queria me adicionar. Durante a tarde, ele postou fotos, respondeu comentários e comentou algumas postagens. Além disso, pude observar que essa criança perguntou também a outras crianças sobre o 5D-NET. Percebi que o artefato estava sendo usado como um meio para ampliar a interação entre esse menino e outras crianças no projeto. A criança ainda não havia feito contato com nenhum paciente de outro estado, porém seu perfil colaborou bastante para aumentar alguns vínculos de amizade dentro do projeto.

\section{Você lê o que os outros postam na 5D-NET?}

$\mathrm{Na}$ maioria das vezes leio as postagens dos blogs que estão nas atualizações mais recentes no 5D-NET.

5. Relate sua impressão sobre o 5D-NET, descrevendo os pontos positivos e restritivos.

Acredito que a ferramenta é de extrema importância no que diz respeito à interação das crianças dentro e fora do estado. O blog possibilita também que as crianças estejam em contato com a leitura e escrita de uma forma mais informal e agradável. Além disso, a 
ferramenta dá a oportunidade da criança rever e refletir o que fez em outras tardes, colaborando para o exercício de sua metacognição.

Durante algumas interações, pude perceber que sempre que a criança quer publicar algo em seu blog, ela precisa da nossa ajuda. O formato me parece um pouco complicado para eles.

No Rio de Janeiro, tenho a impressão de que as crianças têm utilizado mais a ferramenta do que no semestre passado. Observo que eles vêm comentando mais uns com os outros sobre algumas postagens que viram e escreveram no blog. As crianças "antigas" demonstravam menos interesse em acessar seu perfil e postar algo. Algumas crianças gostam de entrar apenas para "passear" por alguns perfis e ler algumas postagens. Não consigo pensar em algo que realmente tenha causado o enfraquecimento da rede, mas talvez para as crianças "antigas" o blog já tenha passado da fase de ser novidade e tudo que deixa de ser novidade, passa a ser menos acessado.

6. Pensando na utilização do 5D-NET e em como torna-lo melhor, deixe suas sugestões/análises.

Pensando na ferramenta como função de promover a interação entre as crianças, acho importante que no blog eles possam encontrar pontos em comum. Talvez a criação de enquetes e rankings seja um boa proposta para chegar a tal objetivo. Além disso, penso que o formato do blog seja um pouco complicado para as crianças. Temos o exemplo da postagem de fotos. É preciso incorporar uma mídia, salvar para depois adicioná-la ao post. Percebo que sempre que uma criança entra no 5D-NET para postar, ela precisa da nossa ajuda para realizar a tarefa.

Estudante: JVSA

Unidade: Rio de Janeiro

1. Com que frequência, em que situações e com quais objetivos você usa o 5D-NET?

Não uso com muita frequência. Somente em alguns momentos que acredito serem importantes e significativos e, consequentemente, digo que até naturalmente, posto no meu perfil do 5D-NET. Ou então com algum objetivo anterior de atingir uma determinada criança ou objetivo.

2. Para você, qual a função desta ferramenta dentro da microcultura 5D?

Depende do tipo de mediação. Mas acredito que a maior função é as crianças poderem compartilhar o que quiserem e poder se comunicar com as crianças dos outros estados que vivenciam o mesmo espaço, podendo assim existir uma troca de experiências.

3. Durante o semestre, você mediou a interação de alguma criança na 5D-NET? Relate com uma pequena descrição e reflexão. 
Uma interação onde pude usar efetivamente o 5D-NET foi a tarde que fiquei com o Nilson. Onde o 5D-NET acabou se tornando um meio que o ajuda em sua memória. É algo que vem dando certo e repetimos tal atividade em todas as tardes com ele. É um instrumento de estratégia que vem sendo bem efetivo e aos poucos o ajudando.

\section{Você lê o que os outros postam na 5D-NET?}

Em alguns momentos sim, se a postagem chamar minha atenção ou de alguma criança específica.

5. Relate sua impressão sobre o 5D-NET, descrevendo os pontos positivos e restritivos.

Bem, o ponto positivo acredito que seja a questão de crianças de vários lugares diferentes tendo acesso a uma mesma ferramenta onde elas a partir disso podem se conectar e trocar experiências entre si, por meio de fotos, vídeos, conversas. É interessante saber que um mesmo ponto liga várias pessoas e que mesmo de longe elas têm a possibilidade de se comunicar. E o ponto negativo acredito que o formato do site, layout no caso, dificulte um pouco o manuseio das possibilidades da ferramenta. Tornando-o difícil e assim ocasionando no não uso do perfil.

Acredito que devido em alguns pontos as crianças e os próprios estudantes encontrarem algumas dificuldades e assim ocasionando no não uso do perfil.

6. Pensando na utilização do 5D-NET e em como torna-lo melhor, deixe suas sugestões/análises.

Acredito que o transformando em algo mais atrativo que possa chamar atenção das crianças. Ou então promover algo que possa de fato liga-las em um interesse em comum. E também que algumas atividades ao invés de sugerir que a criança fosse para o 5D-NET, na hora que ela começasse a atividade o 5D-NET abrisse automaticamente, igual quando acontece com as páginas de internet.

Nome: LAPO

Unidade: Rio de Janeiro

1. Com que frequência, em que situações e com quais objetivos você usa o 5D-NET?

Procuro em todas as tardes convidar a criança a entrar no 5D-NET, costumo fazer o convite no início da tarde, porém quando a criança não aceita proponho novamente no fim da tarde usando de apoio as fotos da tarde ou alguma curiosidade relevante. Os objetivos variam de criança para criança, há crianças que acho importante a relação social, outras usamos para relembrar as atividades da tarde anterior e outras para reforçar a tarde vivida.

2. Para você, qual a função desta ferramenta dentro da microcultura 5D? 
Acredito na ferramenta como um instrumento para que as crianças possam enxergar o projeto em outras unidades e também como troca de ideias, exibindo as diferentes formas de mediar a mesma atividade.

3. Durante o semestre, você mediou a interação de alguma criança na 5D-NET? Relate com uma pequena descrição e reflexão.

Nilson entrou neste semestre no projeto e ainda não tinha uma conta no blog. Em uma tarde eu o propus que criássemos um 5D-NET para ele e o menino concordou. Passamos a tarde inteira em frente ao computador criando e montando o blog, preenchemos todos os campos possíveis e o menino pareceu se divertir. Foi também a partir dessa tarde que descobrimos que o estímulo visual ajudava Nilson a se recordar melhor do que tinha feito durante a tarde e a partir de então Nilson não passa uma tarde sem entrar no blog

\section{Você lê o que os outros postam na 5D-NET?}

Apenas quando estou com as crianças.

5. Relate sua impressão sobre o 5D-NET, descrevendo os pontos positivos e restritivos.

Pontos positivos: Com o auxílio do 5D-NET as crianças podem se relacionar não só entre nossa unidade, mas também em Brasília e São Luís. Considero importante que elas possam enxergar que outras crianças em outros estados vivenciam a mesma microcultura que elas.

Pontos negativos: As transações no blog são bem complicadas e de difícil memorização, não interessando as crianças pelo nível de dificuldade.

Em minha unidade esse enfraquecimento não foi tão brusco, porém acredito que ele aconteceu, pois quando o 5D-NET iniciou ele virou uma obrigação entre os estudantes que aos poucos foi se perdendo e resultou no enfraquecimento.

6. Pensando na utilização do 5D-NET e em como torna-lo melhor, deixe suas sugestões/análises.

Acredito que necessite de um melhor layout, mais dinâmico, que convide as crianças a navegarem.

Nome do Estudante: LMMAM

1. Com que frequência, em que situações e com quais objetivos você usa o 5D-NET?

A frequência com que eu uso o 5D-NET depende da criança com quem eu passo minha tarde. Sempre tento sugerir as crianças que a gente entre para ver as postagens dos amigos, ou para postar alguma coisa relacionada ao que fizemos. Mas as crianças, em 
geral, apresentam certa resistência. Uma estratégia que às vezes funciona é dizer que quero entrar no meu, e dessa forma eu e a criança navegamos juntos. Costumo usar para postar fotos ou comentar os posts das outras pessoas

2. Para você, qual a função desta ferramenta dentro da microcultura 5D?

Acredito que uma das funções planejadas era de que as crianças pudessem conversar com as outras crianças de outras unidades do Sarah. Mas uma das funções que veio com o tempo foi a de reforço da microcultura. Apesar das crianças não usarem com tanta frequência, elas sabem que têm a possibilidade de conversarem com pessoas de outras unidades, e que essas pessoas estão num projeto igual ao nosso. Além disso, quando elas veem as fotos de atividades de outras pessoas, acabam se animando em fazer também.

3. Durante o semestre, você mediou a interação de alguma criança na 5D-NET? Relate com uma pequena descrição e reflexão.

Mediei em algumas vezes. Um dia que me marcou foi quando eu passei a tarde inteira fazendo uma montagem de fotos a respeito do tema de um jogo de memória que joguei com uma das nossas meninas, a Cecília. Escolhemos várias imagens que a faziam lembrar de viagens que ela ou a mãe havia feito e em seguida nós postamos no 5D-NET. Achei importante porque ela é uma das crianças que não gosta de usá-lo. Acredito que a menina ficou tão envolvida com a atividade que a interessava, que se animou em dividir com os amigos.

\section{Você lê o que os outros postam na 5D-NET?}

Costumo ler quando sei que alguma criança postou algo para motivá-la a continuar usando ou quando a criança com quem eu estou entra junto comigo.

5. Relate sua impressão sobre o 5D-NET, descrevendo os pontos positivos e restritivos.

Um dos pontos positivos é a reafirmação da microcultura possibilitada pelo uso do 5DNET. Mas considerando que temos outros meios de fazê-lo, esse não é o mais utilizado e eficaz entre as crianças. Ponto negativo quanto ao 5D-NET em si, eu não vejo. $\mathrm{O}$ problema é a resistência apresentada por elas que muitas vezes atrapalha a interação. Em contrapartida, temos casos específicos em que ele é muito útil. Uma das nossas crianças, o Nilson, sofreu um acidente que prejudicou sua memória. Então usamos essa ferramenta antes e depois da interação com objetivo de trabalha-la.

Um dos possíveis motivos é a falta de interesse das crianças mais novas. Mas acredito que não é uma ferramenta fácil de utilizar e que possui poucas coisas interessantes para troca de informações com as crianças, como "comunidades".

6. Pensando na utilização do 5D-NET e em como torna-lo melhor, deixe suas sugestões/análises.

Podemos rever a parte técnica, como um jeito de voltar para a página anterior, um modo mais fácil e rápido de postar fotos e textos, como achar as informações sobre outras pessoas... e até mesmo o design do 5D-NET pode atrair. 


\section{Estudante: RBLS}

Unidade: Rio de Janeiro

1. Eu não uso o 5D-NET com muita frequência. Se eu fosse fazer uma média, diria que uso a cada 15 a minha conta. Geralmente entro antes das crianças chegarem, durante a reunião das $14 \mathrm{~h}$. Neste tempo, eu olho as atualizações dos blogs do rio e de algumas pessoas dos outros estados que tenho adicionadas. Eu comento mais as postagens do que posto.

2. Para mim, a função desta ferramenta é basicamente de retroalimentação da nossa microcultura. Não enxergo o blog atingindo diretamente a função para qual foi criado no início, de substituir o livro de regras. Com o tempo, ele foi ganhando novos significados, além de instrumento para compartilhar informações sobre atividades do labirinto. Agora, dentro desta retroalimentação, o 5D-NET atua de diferentes modos de acordo com o interesse ou a necessidade de cada um.

3. Sim. Eu mediei várias interações com diferentes crianças. Observei que umas entram por interesse em saber as atualizações, como o Bruno e o Tiago. Temos o caso do Nilson, que tem consciência do benefício do uso do blog por conta do seu problema de memória. Existem crianças que são diferentes, mas usam quando foram estimuladas por mim. E outras que não gostam, e não entram mesmo quando há mediação.

4. Nem tudo. Olho rapidamente a lista de atualizações recentes e só abro o que for interessante par mim. Aí sim, leio e procuro comentar, geralmente com perguntas que incentivem um feedback de quem postou.

5. A primeira impressão que tive do 5D-NET é a de que ele é uma rede de relacionamento, mesmo que limitada às unidades do Sarah. Essa associação com o Orkut ou Facebook, por exemplo, fez com que eu criasse certas expectativas sobre os aplicativos disponíveis. Mesmo não tendo muito interesse pela ferramenta, eu me "obriguei" a usá-la, a fim de dar um sentido a ela, e também quando não conseguem mexer com facilidade. Pontos positivos: promove a interação entre as unidades que possuem o projeto, contribuindo para a valorização do mesmo, por parte dos estagiários e das crianças. Funciona como um registro audiovisual das atividades feitas pelas crianças e para compartilhamento de informações sobre elas. Pontos negativos: não atingiu o objeto para o qual foi criado inicialmente, o de substituir a função do livro de dicas. Não é fácil de mexer, para dominar a ferramenta, é preciso investir um tempo grande para explorá-lo, que nem sempre é disponível durante a interação.

Eu percebi que o uso do blog pelas demais unidades diminuiu através das atualizações. Porém, não sei dizer com certeza o real motivo, pois aqui na unidade do Rio o uso me 
parece constante, claro que não por todas as crianças. A dificuldade no uso da ferramenta e a falta de interesse podem ser alguns motivos da diminuição do uso.

Estudante: RLSC

Unidade: Rio de Janeiro

1 - O uso do 5D-NET se dá em diferentes situações durante as tardes que participo, variam de frequência e objetivos dependendo da criança, de como administramos o tempo e do contexto que se forma durante a tarde.

Algumas vezes o próprio labirinto nos direciona no desafio a postar sobre a atividade que fizemos como: dicas sobre o jogo, fotos ou vídeos, links ou até mesmo um pequeno texto, como se fosse mais uma "etapa" do desafio que escolhemos. Outras vezes a iniciativa de postar uma foto ou vídeo, por exemplo, parte da própria criança durante a interação ou até mesmo do estudante, principalmente quando está relacionado à atividade ou alguma conversa durante a tarde. Geralmente eu procuro incentivar mais a postagem nessas ocasiões, respeitando quando ela não quer, mas procurando dar o incentivo com algumas estratégias, como, por exemplo, abrir e postar no meu perfil do 5D-NET, especialmente com crianças que não o utilizam muito. Já outras crianças abrem por conta própria no começo ou no fim da atividade, muitas vezes sem postar, apenas para responder comentários ou ver o que os outros puseram lá. Por isso, concluo que a frequência com que entro varia de acordo com a criança com quem passo minhas tardes e às vezes, quando consigo um tempo na reunião de duas horas, tento entrar para comentar e postar.

Os objetivos, assim como a frequência, variam com a criança e a intenção que temos ao entra ou postar algo. Em alguns casos, o objetivo pode ser, como eu disse antes, comprimir mais uma "etapa do desafio" proposto pelo labirinto e sustentado por mim ou pela criança. Pode ser para aproveitar um momento significativo da tarde e retomá-lo, também de uma tarde anterior ao respondermos os comentários, tentando fazer com que eles se lembrem de e reflitam sobre esse momento, talvez em algum ponto levando-os a metacognição. Ainda outro objetivo, como num caso específico aqui da unidade do Rio, pode ser trabalhar diretamente a memória, postando uma foto sobre a tarde e contando o que aconteceu, ainda em outra tarde usar esse post para retomar o dia, assim como fazemos todas as tardes com esse menino (Nilson). Entre outros, acredito que esses sejam os principais objetivos que tento atingir ao usar o 5D-NET.

2 - Acredito que esse artefato tenha várias funções, entre elas: retroalimentar a relação das crianças com o labirinto, pois muitas vezes o ato de postar é sugerido pelos desafios nele encontrados e muitas vezes também o que é postado tem ligação direta com o desafio; enfatizar tudo que aconteceu nessa tarde e em outras interações; possibilitar outra forma de nós nos comunicarmos com eles, eles com seus pares de nossa unidade e de outras, dando para as crianças essa noção de que existem outras "5D"; trabalhar algumas funções como a memória e outras indiretamente; exercitar a metacognição, pois acredito que através dele eles relembrem os momentos da tarde e reflitam sobre esses, ao escreverem sobre a atividade, comentar o post de um colega sobre a atividade que já fez e responder seus comentários; entre tantas outras. 
3 - Durante esse semestre, por várias vezes eu pude mediar a interação de várias e também das mesmas crianças no 5D-NEG, como no caso de algumas crianças que entram todas as tardes ou de outras que pouquíssimas vezes entraram, porém vou destacar a tarde que passeio com o paciente Thiago. Thiago é um menino que está conosco desde o semestre passado e, desde então, tem feito uso do seu perfil no 5DNET, porém o menino tem o hábito de entrar todas as tardes, mas quase nunca posta nada, apenas dá uma breve olhada no que foi postado. Em uma das tardes que passamos juntos, como de costume, quando ele abriu seu labirinto, abriu também o seu 5D-NET. Entretanto, viu um post sobre futebol que lhe interessou muito, aproveitei a deixa e incentivei-o a comentar e, assim, foi, ele comentou neste e depois abrimos outras coisas, adicionamos mais amigos, visitamos vários blogs e vimos vários posts e, como consequência, passamos a maior parte da tarde no 5D-NEG e, depois de termos feito apenas uma atividade, voltamos para o 5D-NET para ver se mais alguma criança havia feito essa. Pensando sobre essa tarde, gostaria de destacar como acho importante incentivar os vários possíveis usos do 5D-NET e sei que também é importante postarmos (até para que se tenha o que ver e comentar), mas acredito que esse tipo de interação com a ferramenta também é muito válido.

4 - Sempre que possível, procuro ler e comentar o que as crianças publicaram, até para alimentar aquele post, mas confesso que, devido ao tempo e a priorizar que a criança faça uso, deixo a deixo a desejar nesse quesito.

5 - Acredito que os objetivos traçados para essa rede de relacionamento são muito positivos, porém nem sempre conseguimos fazer com que as crianças valorizem tanto seu uso como o momento de jogar, por exemplo, por isso acaba se tornando uma atividade "extra, se der tempo". Alguns pontos positivos que consigo ver é como ele pode ser usado para dar "ênfase ao momento "bem legal" da tarde, para que as crianças se comuniquem, aprendam até a mexer mais no computador, vejam que seus pares também fazem as mesmas atividades entre outros. Alguns pontos negativos, em minha opinião, as crianças veem o 5D-NET como algo que toma tempo de outra atividade, como de um jogo e também a dificuldade que alguns têm com a rede, com na hora de postar fotos e vídeos ou procurar algum amigo. Além de ser uma atividade um pouco difícil, exige tempo e concentração, duas coisas que são difíceis para as crianças aqui no Rio manterem.

Em minha unidade, não pude perceber um declínio tão grande, porém pude perceber que: as crianças que, desde o começo não gostavam de usar o 5D-Net permaneceram assim e foram utilizando ainda menos. As crianças que gostaram desse continuam usando com frequência, porém algumas delas de maneira diferente. Aqui é muito comum que uma criança entre em várias tardes e não poste nada, só olhe e talvez comente. Portanto, não percebi um declínio tão grande em minhas interações.

6 - Pensando em algumas sugestões para a utilização do 5D-NET, ao meu ver, seria melhor se esse fosse um pouco mais fácil de utilizar, de postar fotos, vídeos, achar amigos. Tudo isso é um pouco difícil, pois envolve muitos caminhos. Outra sugestão seria que o layout fosse um pouco mais atrativo, mostrasse mais posts dos meus amigos, mais fotos, mostrasse quem comentou nas minhas fotos dentro do 5D-NET e, como foi dito em uma das reuniões, acredito que um ranking com os jogos mais frequentes seria bem legal. 
Nome: SBR

Unidade: Rio de Janeiro

1 - Com que frequência, em quais situações e com quais objetos você usa o 5D-NET?

Minha frequência no 5D-NET podia ser melhor. Entro pelo menos uma vez na semana para ver as postagens recentes e quando alguma interação me remete a ele, como a publicação de uma foto da minha tarde de interação com a criança. Minha utilização no 5D-NET tem como objetivo alimentar a ferramenta para se tornar atrativa para a criança ter vontade de entrar e vir o comentário ou a postagem. E na interação, uso com o objetivo da criança fazer uma metacognição do que produziu durante a tarde.

2 - Para você, qual a função desta ferramenta dentro da microcultura 5D?

O D5-NET tem várias funções na microcultura e isso muda de criança para criança. Para algumas, como no caso de Nilson, serve para exercitar a memória, já que com as interações descobrimos que, através de sua memória visual, ele é capaz de se lembrar de fatos passados.

Para outras crianças, serve como uma maneira delas refletirem sobre o que fizeram na tarde, postando uma foto ou um comentário sobre a mesma. Para outras, tem a função da interação com os demais usuários da ferramenta, visando se integrar e descobrir fatores em comum, como os desafios do labirinto e até mesmo fortalecer os laços criados fora da rede social. A função varia de criança para criança e a maneira como a ferramenta é mediada na interação.

3 - Durante o semestre, você mediou a interação de alguma criança no 5D-NET? Relate com uma pequena descrição e reflexão.

$\mathrm{Na}$ minha última interação, interagi com Cecília e, quando estávamos no caminho até a 5D, ela comentou que tinha postado uma foto no 5D-NET em sua outra interação. Quando chegamos, disse que queria ver a foto, ela entrou no 5D-NET e tinha comentários. Cecília fez questão de responder e ainda brincou com uma das estudantes. Perguntei o que ela queria fazer no 5D-NET, a criança respondeu que queria ir para o labirinto brincar, e não queria perder mais tempo.

Cecília se empolgou quando viu que tinha comentários na foto e se mostrou muito interessada em responder os comentários, mas com demorou muito tempo escrevendo, já que tem uma grande dificuldade de escrita, a menina perdeu o interesse rápido, por mais que na interação eu tenha tentado fazer explorar mais o 5D-NET. O fato de a criança pensar que vai perde tempo é um tanto quanto comum, o interesse no 5D-NET não é tão grande o suficiente para que seja igualado ao interesse de fazer os desafios.

4 - Você lê o que os outros postam no 5D-NET?

Sim e sempre procuro comentar nas publicações que vejo e acho interessante. 
5 - Relate sua impressão sobre o 5D-NET, descrevendo pontos positivos e restritivos.

Como ponto positivo, o 5D-NET tem uma ótima ideia no geral. Ele é alimentado pelo labirinto e tem várias funções na microcultura que podem ser exploradas de diversas maneiras pela mediação. $\mathrm{O}$ fato de ser uma rede social ajuda na interação das próprias crianças, que, mesmo com a presença física, muitas vezes a interação entre elas é escassa e o 5D-NET vem para ajudar nisso. Não vejo pontos negativos quanto ao objetivo do 5D-NET, mas funcionalidade sim. A forma de se postar uma foto é muito complicada, é um processo que é difícil de memorizar e entender. Quanto à parte do layout, eu acho não muito atrativo a ponto da criança ter interesse de entrar apenas olhando tendo o labirinto em paralelo, cheio de brincadeiras.

No Rio de Janeiro, eu enxerguei esse enfraquecimento. Crianças novas entraram no projeto e a frequência delas no 5D-NET é maior em relação às crianças antigas quando entraram. Acho que esse fato se deu por que nós, alunas, tínhamos mais controle sobre a ferramenta tornando a interação mais fácil e, com isso, exploramos mais o interesse das crianças para usarem a ferramenta. Eu notei esse enfraquecimento nas outras unidades, visando que só existiam postagens e comentários de usuários na unidade do Rio de Janeiro.

6 - Pensando na utilização do 5D-NET e em como torná-lo melhor, deixe suas sugestões/ análise.

Partindo dos pontos negativos, acho que mudar o modo de postagem para uma coisa mais dinâmica e prática, seria uma ideia. E o layout podia ser mais atrativo. Muitas redes sociais têm em suas páginas iniciais as últimas postagens dos usuários que lhe interessa. Acho que isso poderia ser uma ideia para atrair a criança a alimentar o 5DNET com comentários. Recursos que facilitem o uso de todas as ferramentas que tem no 5D-NET, como postagem de fotos, vídeo, publicação de status etc.

Estudante: Aline

Unidade:

ATIVIDADE: TEXTO SOBRE 5D-NET. As perguntas abaixo são um roteiro para que possamos refletir sobre o sentido da 5D-NET. Você pode respondê-las uma a uma ou fazer um relatório corrido que contemple os diferentes tópicos. Fique à vontade para fazer referência a qualquer tema que não tenha sido contemplada neste roteiro, mas que tenha relação direta ou indireta com a 5D-NET.

1. Com que frequência, em quais situações e com quais objetivos você usa o 5D-NET?

Uso o 5D-NET semanalmente ou a cada duas semanas, sempre que acho que tenho alguma coisa legal para dividir com o pessoal da rede. Posto no blog por achar que, 
quando um estudante usa a ferramenta, é um incentivo maior para as crianças usarem também, afinal servimos de modelo para elas.

2. Para você, qual a função desta ferramenta dentro da microcultura 5D?

Para mim, essa ferramenta tem função de interação social. Nos possibilita interagir com crianças e estudantes de outros estados.

3. Durante o semestre, você mediou a interação de alguma criança na 5D-NET? Relate com uma pequena descrição e reflexão.

Sim. Mediei junto com outra estudante a interação de uma criança no 5D-NET. Estávamos em busca de uma atividade e a estudante sugeriu que a menina acessasse o blog. A criança se negou, mas eu disse "ah, Manu, olha lá. Vê as minhas postagens também. Eu e a Thaisa temos umas postagens recentes bem legais". Depois disso, ela entrou por curiosidade. A estudante disse que fazia muito tempo que a criança em questão não postava no blog e sugeriu que ela postasse também para que ficássemos todas como os nossos blogs atualizados.

A Manu aceitou e postou uma foto que ela escolheu e pediu que a ajudássemos a escrever uma legenda. Acredito que a aceitação da criança depende da mediação dos estudantes e o fato de estarmos usando o blog facilitou nesse momento. Ela viu que usamos e, a partir do nosso modelo, ela se sentiu motivada a usar.

4. Relate sua impressão sobre o 5D-NET, descrevendo pontos positivos e restritivos.

Os pontos positivos são facilitar em interações a distância, postar imagens, vídeos, enfim, de algo que achamos legal para dividir com o pessoal da rede, construir um perfil repensando na construção da própria imagem.

Como pontos negativos, o 5D-NET não notifica quando alguém comenta em uma postagem, ou nos adiciona à sua rede de amigos. Se não verificamos todas as nossas postagens e a postagem em que comentamos, não tem como saber se alguém comentou, se a pessoa respondeu nossa postagem.

Não sei explicar por que, mas, como já mencionei, os próprios estudantes não utilizam a ferramenta. No módulo passado, os estudantes e as crianças postavam mais. Diante da falta de interesse dos estudantes, a mediação com uma criança fica enfraquecida para que elas se interessem pelo blog.

5. Pensando na utilização do 5D-NET e em como torná-lo melhor, deixe suas sugestões/ análise.

Penso que o blog deveria oferecer ferramentas com notificar quando alguém comentasse nas postagens, quem sabe um bate-papo em que pudéssemos conversar diretamente com as pessoas da rede sem que fosse necessário comentar na postagem. Se tivesse uma cara mais parecida com as redes sociais com as redes sociais que usamos frequentemente. 
Nome: ACMR

Unidade: São Luis

As perguntas abaixo são um roteiro para que possamos refletir sobre o sentido da 5DNET. Você pode respondê-las uma a uma ou fazer um relatório corrido que contemple os diferentes tópicos. Fique à vontade para fazer referência a qualquer tema que não tenha sido contemplada neste roteiro, mas que tenha relação direta ou indireta com a 5D-NET.

1. Com que frequência, em quais situações e com quais objetivos você usa o 5D-NET?

Uso o 5D-NET com pouca frequência, mas, quando entro, é para olhar postagens de outros estudante, para postar alguma foto de uma tarde de interação; com o objetivo de que meus amigos olhem e para que os que ainda não são meus amigos (estudantes de outras unidades) me adicionem.

2. Para você, qual a função desta ferramenta dentro da microcultura 5D?

Tem como principal função, em minha opinião, "integrar" a criança em um contexto bem atual da Internet, pois ela poderá expressar o que é, o que sente e o que quer, do seu jeito, tendo acesso também a essas informações de outras crianças!

3. Durante o semestre, você mediou a interação de alguma criança na 5D-NET? Relate com uma pequena descrição e reflexão.

Não foi bem na 5D-NET, mas uma "apresentação" do artefato, com o João Guilherme. $\mathrm{Na}$ tarde, fomos para o computador, e eu, com o intuito de incentivar o uso do labirinto, entre com ele, mas ele perguntou o que era "aquilo do lado", e eu disse que era o blog, que os estudantes e algumas crianças tinham. Eu perguntei se ele não tinha, e ele me respondeu que não. Eu perguntei a ele se havia interesse por aquele artefato, e ele falou que sim. Mas, quando eu mencionei que tínhamos que criar um e-mail para ele, com uma senha etc, ele disse que era pra deixar para depois. Minha reflexão sobre é que todas as crianças mais antigas na 5D têm o blog, mas as que entraram agora não. Então não é com o pessoal da informática esse cadastro das crianças? Algo que ficou bastante vago e não pode ser explorado e, devido a isso, ficamos de ter um retorno do pessoal da informática, mas não tivemos.

4. Relate sua impressão sobre o 5D-NET, descrevendo pontos positivos e restritivos.

O 5D-NET é um artefato que poderia ser mais utilizado por crianças mais velhas, adolescentes, mas pode ser legal também de despertar o interesse nas crianças, para fazer amizades! Um ponto positivo é a proximidade com o labirinto e consequentemente com o og@mm. E um ponto negativo seria justamente o "não interesse" da criança pelo artefato, talvez por não saber usar direito o computador, por não saber ler etc. 
Particularmente falando, eu não gosto muito de expor "minha vida", meu cotidiano, em redes sociais e afins, então eu talvez tenha criado uma barreira quanto a isso e, pelo que vejo dos outros estudantes, alguns também se sentem do mesmo jeito. Então, esse pode ser um motivo, a "não apresentação" do artefato para as novas crianças e o reforçamento do uso para as mais antigas, pode ser outro fator!

5. Pensando na utilização do 5D-NET e em como torná-lo melhor, deixe suas sugestões/ análise.

O 5D-NET é um artefato que pode ser mais interessante se chamasse mais atenção, se tivesse como personalizá-lo, colocando papeis de parede, colocando músicas, envolvendo outros artefatos nele mesmo, para que ficasse mais com a "sua cara"!

Estudante: DCS

Unidade: São Luis

1. Com que frequência, em quais as situações e com quais objetivos você usa o 5DNET?

Raramente utilizo o 5D-NET, porém todas as vezes que tentei introduzir essa ferramenta na interação, foi quando a criança demonstrou interesse e com objetivo de mostrar a ferramenta para que a criança conhecesse.

2. Para você, qual a função desta ferramenta dentro da microcultura 5D?

Bom, o 5D-NET teria a função de promover o contato entre as crianças e estudantes do $5 \mathrm{D}$, incluindo as outras redes, fazendo com que elas interagissem e também pudessem ver um pouco do que acontece nos programas umas das outras.

3. Durante o semestre, você mediou a interação de alguma criança na 5D-NET? Relate com uma pequena descrição e reflexão.

Bom a mediação que houve foi em uma atividade coletiva, que foi a caça aos ovos, na qual utilizamos do blog como pista para encontrar o tesouro, postamos a foto do local do tesouro no blog como pista para encontrar o tesouro, postamos a foto do local do tesouro no blog de um dos estudantes, para que as crianças acessassem e conseguissem ver a pista, porém acho que a forma com utilizamos a ferramenta não deu valor a sua real função.

\section{Relate sua impressão sobre o 5D-NET, descrevendo pontos positivos e restritivos.}

Bom, o 5-NET pra mim, ainda é um mundo desconhecido. Como relatei, não tive muito contato com essa ferramenta, então a impressão que tenho ainda é muito do que me falaram. Vejo o blog como uma boa ferramenta, a ideia das postagens, do contato com as outras 5D é um aspecto muito positivo, porém ainda não consegui ver o blog voltado pra crianças. 
A rede foi se enfraquecendo e muito tem de responsabilidade nossa (estudantes). Não sabemos utilizar dessa ferramenta como forma de media nossas interações, não tínhamos motivação nem conhecimento da ferramenta para poder expor para as crianças.

5. Pensando na utilização do 5D-NET e em como torná-lo melhor, deixe suas sugestões/ análise.

Fazendo uma análise da 5D-NET, ainda não consigo pensar em nenhuma sugestão. Como comentei acima, muito do que sei do 5-NET foi o que me falaram, então, por não ter um conhecimento mais aprofundado, não consegui elaborar uma sugestão.

Estudante: JFLR

Unidade: São Luis

Enunciado da atividade:

As perguntas abaixo são um roteiro para que possamos refletir sobre o sentido da 5DNET. Você pode respondê-las uma a uma ou fazer um relatório corrido que contemple os diferentes tópicos. Fique à vontade para fazer referência a qualquer tema que não tenha sido contemplada neste roteiro, mas que tenha relação direta ou indireta com a 5D-NET.

1. Com que frequência, em quais situações e com quais objetivos você usa o 5D-NET?

Durante o semestre, usei o 5D-NET (blog) em apenas algumas poucas ocasiões. No começo do módulo, não estávamos registrados e, quando conseguimos o login, usei-o apenas na interação entre 2 ou 3 crianças rapidamente. Uma dessas interações foi numa gincana que fizemos no espaço da $5 \mathrm{D}$, em que um dos desafios estava presente no mural de um dos estudantes e as crianças precisavam acessá-lo. Usamos geralmente com o objetivo de ver as postagens dos estudantes das outras 5D e para estimular que as crianças também façam suas próprias postagens.

2. Para você, qual a função desta ferramenta dentro da microcultura $5 \mathrm{~d}$ ?

O 5D-NET tem a função de socializar a criança por meio da Internet, fazendo com que ela possa expressar o que sente, suas experiências e sua opinião acerca das atividades de outras crianças.

3. Durante o semestre, você mediou a interação de alguma criança da 5D-NET? 
Sim. Durante a tarde do dia 22/06, tirei fotos de uma das crianças para que ela conseguisse colocar a foto no seu avatar, postamos a foto no seu mural, escrevemos mensagens no mural de outros estudantes e editamos seu perfil.

4. Relate sua impressão sobre o 5D-NET, descrevendo pontos positivos e restritivos.

Um ponto positivo acerca do 5D-NET é sua proximidade com o Labirinto, pois ao mesmo tempo em que a criança desenvolve a atividade de se comunicar com o $\mathrm{Og} @ \mathrm{MM}$, facilita o login no blog. Além disso, acredito que, quando a criança vê as atividades de outras crianças das demais 5D, sente-se mais participante do projeto no qual está inserida. Um ponto negativo no blog é a dificuldade de postagem de arquivos, o que dificulta a postagem de atividades. Além disso, a tela inicial do blog é pouco chamativa, o que muitas vezes faz com que a criança não se interesse imediatamente.

Respondendo essa pergunta de acordo com a minha experiência, acredito que o pouco uso do 5D-NET acontece pela baixa frequência de postagens e comentários de outras crianças, foco das crianças em outros artefatos dentro da 5D e desconhecimento sobre as informações de login na entrada do 5D-NET.

5. Pensando na utilização do 5D-NET e em como torná-lo melhor, deixe sua sugestão/ análise.

Acredito que o 5D-NET pode ter um layout mais chamativo para as crianças e adolescentes da 5D. A página inicial de um usuário contém basicamente palavras, o que torna a visita a outros pontos do site desinteressante. Seria uma boa ideia que, tal qual o labirinto, os usuários recebam notificações sobre fotos comentadas, amigos adicionados, fotos postadas, mensagens recebidas etc.

Estudante: JCON

Unidade: São Luis

1. Com que frequência, em quais situações e com quais objetivos você usa o 5D-NET?

Geralmente a 5D-NET não é muito frequente nas minhas interações, mas nas vezes em que aconteceu a utilização do artefato foi para integrar as crianças com o blog e com as crianças de outras 5Ds no país.

2. Para você, qual a função desta ferramenta dentro da microcultura 5D?

Acredito que além de estimular o uso das mídias e a integração com estudantes e crianças de outros estados, a 5D-NET funciona como uma ferramenta para que a criança interaja com o próprio espaço e os amigos da sua 5D.

3. Durante o semestre, você mediou a interação de alguma criança na D5-NET? Relate com uma pequena descrição e reflexão. 
A Emmanuele entrou na 5D-NET, mas não quis postar foto ou alguma mensagem, apenas vascular fotos antigas de outros módulos do qual ela participou. Ela pareceu mais utilizar a ferramenta para se lembrar e ter recordações de atividades passadas e dos integrantes antigos da 5D.

4. Relate sua impressão sobre o 5D-NET, descrevendo pontos positivos e restritivos. Positivamente, a 5D-NET é um artefato de grande utilidade para interação social e tecnológica da criança, porém é muito experimental e crua para que as crianças possam realmente se divertir e gostar de utilizá-la.

Acredito que sim, tanto por parte das crianças que não demonstraram muito interesse na ferramenta, quanto por parte dos estudantes, por talvez não incentivarem tanto $\mathrm{e}$ saberem envolvê-las na D5-NET.

5. Pensando na utilização do 5D-NET e em como torná-lo melhor, deixe suas sugestões/ análise.

Acredito que o que falta para o 5D-NET é ser mais atrativa visualmente à criança. Além disso, ela ter a possibilidade de expressar mais seus sentimentos e emoções, além de poder servir com uma espécie de diário virtual para que elas contem sobre seu humor e como foi seu dia/semana.

Estudante: LLCR

Unidade: São Luis

1. Com que frequência, em que situações e com quais objetivos você usa o 5D-NET?

Uso o 5D-NET com pouca frequência. Utilizei uma vez com a Manu no intuito de que colocássemos a foto que tirei do seu convite de aniversário que confeccionamos, mas a Manu entrou, não ficou por muito tempo e não quis por. Queria que ela tivesse colocado na 5D-NET, para mostrar a habilidade que teve em fazer o envelope do convite comigo para as outras crianças e estudantes.

2. Para você, qual a função desta ferramenta dentro da microcultura 5D?

Através do blog, a criança pode aperfeiçoar a habilidade de organizar e planejar. "Primeiro, tirar uma foto que represente algo para a criança, escolher a que mais gostou, colocá-la no blog, observar e pensar no que deve escrever para apresentar a foto às outras crianças". São sequencias de atividades que trabalham com a cognição da criança. Além de melhorar o comportamento social, fazer amizades com as crianças do projeto 5D de outro estado, ampliando o grupo de iguais e compartilhando experiências.

3. Durante o semestre, você mediou a interação de alguma criança na 5D-NET? 
A Manu. Tivemos várias oportunidades de colocar fotos e escrever, mas, apesar da minha sugestão para que fizéssemos isso, ocorreu apenas uma vez, quando ela trocou sua foto do perfil e adicionou os estudantes novos.

4. Relate com uma pequena descrição e reflexão sua impressão sobre o 5D-NET, descrevendo pontos positivos e restritivos.

O 5D-NET é um espaço onde a criança e o estudante podem colocar suas impressões de determinado assunto, por fotos que lhes interessem apresentar alguma atividade feita na D5 para outras crianças e estudantes de outro estado, postar vídeos. Mas, algumas crianças não apresentam interesse de utilizá-lo, talvez pelo layout que poderia ser mais colorido e lúdico, para que chamasse a atenção das crianças. Seria o ponto. O 5D-NET deveria apresentar mais recursos lúdicos para suscitar o interesse da criança.

Fazer com que a criança utilize o D5-NET não depende apenas da iniciativa própria da criança, é preciso que o estudante fale a respeito dele, apresentando-o em oportunidades nas quais a criança esteja flexível ao seu uso.

5. Pensando na utilização do 5D-NET e em como torná-lo melhor, deixe suas sugestões/ análise.

Citei em pontos negativos, reforçarei falando do layout do blog: cores alegres e animações como desenhos talvez chame mais a atenção da criança, a opção da própria criança mudar a cor do blog, por plano de fundo e ouvir músicas, dentre outros.

Nome do Estudante: NNR

Unidade: São Luis

1. Com que frequência, em que situações e com quais objetivos você usa o 5D-NET?

Utilizo o 5D-NET com pouca frequência, quando tiramos algumas fotos ou elaboramos vídeo em alguma interação, para mostrarmos para as outras crianças e estudantes de outros estados, aprimorar a habilidade social da criança fazendo com que um criança daqui interaja com outra criança de outras unidades da 5D.

2. Para você, qual a função desta ferramenta dentro da microcultura 5D?

Despertar interesse na criança para que haja uma socialização entre várias crianças e estudantes.

3. Durante o semestre, você mediou a interação de alguma criança na 5D-NET? Relate com uma pequena descrição e reflexão.

Sim. Utilizei o blog com o Alisson. Tudo aconteceu quando ele chegou à sala do projeto $5 \mathrm{D}$, e eu e o Jefther demos a ideia dele tirar uma foto e colocar no perfil do seu blog. Ele aceitou e foi até o balanço dizendo que queria tirar foto naquele local. Então pegamos a 
câmera e tiramos a foto. Escolhemos duas, uma para ele colocar no perfil do seu blog e a outra para fazer uma postagem.

\section{Reflexão}

Essa utilização do blog fortifica os laços entre criança e estudante, pois possibilita a socialização da criança e possibilita interações com todos no blog, capacitando e contribuindo para o seu processo de socialização e o seu desenvolvimento.

4. Relate sua impressão sobre o 5D-NET, descrevendo os pontos positivos e restritivos.

O blog é uma ferramenta que apresenta várias habilidades, tais como: permitir conhecer outras pessoas, surgindo assim uma interação entre as duas partes, tanto entre os estudantes como entre a criança; é uma forma de conhecer o que as crianças pensam a respeito das outras; é uma maneira delas se expressarem e falarem do que estão pensando sobre alguma postagem; contribui para a formação do indivíduo, já que assim ele conhece outros interesses de outras crianças e assim passa a desenvolver a sua própria autocrítica em relação ao que vê; esses são os pontos positivos. Já os pontos negativos podem ser: se não houver interesse da criança, a utilização do blog não irá contribuir em nenhum aspecto; é preciso que haja mediação entre estudante e criança para a utilização do blog, para que essa ferramenta não se transforme em algo sem importância.

Percebemos sim certo enfraquecimento dessa rede de relacionamento, devido à falta de interesse das crianças, já que não havia nenhuma motivação da parte dos estudantes, pois quase não esteva se incentivando a utilização do blog e isso possibilitou o enfraquecimento dessa rede.

5. Pensando na utilização do 5D-NET e em como torna-lo melhor, deixe suas sugestões/análises.

Poderia sugerir que o blog ganhasse um cenário novo, assim como também pudesse permitir conversas entre crianças dessa unidade com as crianças de outras unidades, possibilitando que isso aconteça de forma on-line. Também seria bom se o blog disponibilizasse alguns jogos divertidos no próprio blog que contribuísse para o desenvolvimento da criança.

Estudante: PHMD

Unidade: São Luis

Questões sobre o 5D-NET

1. Com que frequência, em quais situações e com quais objetivos você usa o 5D-NET? 
Utilizo em poucos momentos para fazer algumas postagens de fotos de interações, olhar as postagens de algumas crianças e estudantes de outros módulos, ver um pouco do que eles fazem, ter ideias para atividades, conhecer um pouco do ritmo das outras unidades etc.

2. Para você, qual a função desta ferramenta dentro da microcultura 5D?

É uma boa oportunidade pra as crianças criarem novas amizades, expressarem-se através das postagens, de coisas que gostam, de fotos de dias que foram significativos a elas ou de algo que gostariam de fazer.

3. Durante o semestre, você mediou a interação de alguma criança na D5-NET?

Relate com uma pequena descrição e reflexão.

Não. Sugeri em alguns momentos utilizarmos da figura mítica do Og@Mm para incentivar o uso de algumas crianças, mas particularmente nunca consegui mediar uma interação que o envolvesse. Nos momentos em que consegui despertar interesse na criança, houve problemas com cadastro e não conseguimos acessar, mas posteriormente a essa época não consegui nenhuma vez.

4. Relate sua impressão sobre o 5D-NET, descrevendo pontos positivos e restritivos.

Alguns pontos positivos eu citei em algumas questões anteriores, com a possibilidade de as crianças conhecerem umas as outras de várias unidades, descobrir afinidades; há a possibilidade de conhecer um pouco do que ocorre nas outras unidades; conhecer pessoas novas, conhecer coisas novas, pois muitos estudantes e algumas crianças de outras unidades postam receitas de culinária, jogos etc.

Alguns pontos negativos que vejo são a pouca atratividade do layout da página, as cores não chamam muita atenção, não há aviso de quem postou na página, como, por exemplo: "Chico Bento comentou em sua foto, ou escreveu um recado".

Não sei explicar exatamente o motivo, pois na unidade de São Luís, nesse semestre seu uso não foi muito efetivo desde o início. Creio que foi um artefato deixado um pouco de lado pelos estudantes deste módulo, pois se ouve falar que o uso da ferramenta era consolidado no módulo anterior com outra levada de estudantes. Talvez tenhamos priorizado outras atividades e não nos atentamos às possibilidades desta ferramenta.

5. Pensando na utilização do 5-NET e em como torná-lo melhor, deixe suas sugestões/ análise.

Acredito que a sua utilização seria mais efetiva se o layout passasse por algumas modificações, utilizasse de cores mais atrativas para as crianças, um design mais arrojado, talvez mais parecido com as redes sociais atuais. Seria útil ter uma caixa de avisos de mensagens ou ações de outros usuários com no Facebook. Não sei se seria útil no contexto do projeto a acessibilidade do 5D-NET fora do hospital, com um site, para as crianças poderem explorá-lo em casa. 
Nome do Estudante: TRSPM

Unidade: São Luis

Questões sobre o 5D-NET

1. Com que frequência, em que situações e com quais objetivos você usa o 5D-NET?

Quase não uso o 5D-NET. Usei algumas vezes para olhar algumas postagens das outras $5 \mathrm{D}$, para ter uma noção do que postar e como andam as tardes de interações nos outros estados.

2. Para você, qual a função desta ferramenta dentro da microcultura 5D?

É uma ferramenta que vem dar oportunidade para as crianças e os estudantes fazerem novas amizades. Se expressarem através das postagens e se identificar com as postagens dos outros integrantes das 5D.

3. Durante o semestre, você mediou a interação de alguma criança na 5D-NET? Relate com uma pequena descrição e reflexão.

Não. Infelizmente ainda não consegui mediar uma interação. Já tentei algumas vezes, mas com quem já tentei não foi mostrado interesse e posteriormente não tentei mais.

Reflexão

Essa utilização do blog fortifica os laços entre criança e estudante, pois possibilita a socialização da criança e possibilita interações com todos no blog, capacitando e contribuindo para o seu processo de socialização e o seu desenvolvimento.

4. Relate sua impressão sobre o 5D-NET, descrevendo os pontos positivos e restritivos.

A possibilidade da criança e do estudante realizarem novas amizades, se identificarem através das postagens seriam pontos positivos que o 5D-NET proporciona dentro da microcultura.

Como ponto negativo, o layout do 5D-NET não prende a criança nem o estudante. No meu caso me sinto pouco atraída pelo Blog, desmotivada para postar.

Muitas das vezes a criança já chega em mente com a atividade que deseja realizar. A criança não mostra interesse em acessá-lo. $\mathrm{O}$ estudante acaba não insistindo no uso e acaba caindo no esquecimento.

5. Pensando na utilização do 5D-NET e em como torna-lo melhor, deixe suas sugestões/análises.

A aparência é tudo. O layout do 5D-NET deve mudar, algo que prenda as crianças e os estudantes, algo que faça sentir vontade de acessar e usar, realmente, o blog. 
Nome: TDRG

Unidade: São Luis

ATIVIDADE: TEXTO SOBRE 5D-NET. As perguntas abaixo são um roteiro para que possamos refletir sobre o sentido do 5D-NET. Você pode responde-las uma a uma ou fazer um relato corrido que contemple os diferentes tópicos. Fique à vontade para fazer referência a qualquer tema que não tenha sido contemplado neste roteiro, mas que tenha relação direta ou indireta com a 5D-NET.

1. Com que frequência, em que situações e com quais objetivos você usa o 5D-NET?

Procuro sempre estar acessando. Nem sempre faço atualizações, mas olho o blog de outras crianças para que em uma interação eu possa sugerir algo bacana para a criança ver. Também costumo entrar no blog quando tenho alguma foto, desenho ou vídeo legal para postar e mostrar para os estudantes e as crianças, ou como já houve casos de crianças pedirem para eu entrar primeiro no meu blog para elas entrarem nos delas após.

2. Para você, qual a função desta ferramenta dentro da microcultura 5D?

Além de ser uma ferramenta que se encontra em um meio de comunicação bastante utilizado pelas crianças, ela possibilita aqui na 5D uma interação social entre nós estudantes e crianças, além de estimular também a escrita, a leitura etc.

3. Durante o semestre, você mediou a interação de alguma criança na 5D-NET? Relate com uma pequena descrição e reflexão.

Em uma interação com a Manu, sugeri que entrássemos no blog. Ela aceitou e quando entramos começamos a olhar o perfil de todos da sala. No perfil de cada pessoa tem a última vez em que a mesma fez sua última postagem. A última postagem que ela tinha feito tinha sido há duzentos e poucos dias. Eu olhei que o meu tinha sido há 23 dias e a Aline há 13 dias. Ela começou a dizer que aquilo não ficaria assim e que ela iria postar uma foto naquele momento. Perguntou-me onde ficavam as fotos. Fui apontando na tela do computador e ela seguindo o que eu falava. Disse que queria ver uma foto dela com os estudantes antigos. Mostrei a pasta que tinha e ela foi em seguida clicando em algumas para escolher a que gostava mais. Ela gostou da foto em que estávamos fazendo o Suco Cremoso. Depois de escolhida a foto, foi a hora de postar. Como tinha que descrever a foto e colocar um título, perguntávamos para ela o que gostaria de escrever sobre aquela foto. Ela ficou meio pensativa e eu e a Aline tentávamos mostrar algumas sugestões. Perguntávamos o que ela sentiu quando olhou a foto, o porquê daquela foto e, diante do que ela ia escrevendo, colocamos um título.

Essa interação com a Manu foi o "retorno" dela ao blog. Depois de muito tempo, conseguimos tirá-la um pouco de outras atividades que ela estava fazendo constantemente. Hoje eu e Aline fomos os modelos dela para que ela se empolgasse tanto em fazer uma postagem. E já combinamos com os outros estudantes procurar estratégias para que ela se envolva e se interesse cada vez mais pelo blog, usando Og@MM como ponte também, para estimular sua autonomia na leitura e escrita. 
4. Relate sua impressão sobre o 5D-NET, descrevendo os pontos positivos e restritivos.

Os pontos positivos: é um facilitador nas interações. As crianças escolhem e postam fotos, vídeos.

Como pontos negativos: o blog não tem uma sala de bate papo, o que ajudaria ainda mais a comunicação das crianças de toda a Rede Sarah. Não possui um notificador avisando quem te adicionou, que comentou na sua foto.

Se nós estudante que somos os mediadores da interação não nos interessarmos ou até mesmo comentarmos sobre ele, as crianças com certeza irão esquecer. O interesse que cada criança tem é diferente, o que pode desvia-la dessa ferramenta.

5. Pensando na utilização do 5D-NET e em como torna-lo melhor, deixe suas sugestões/análises.

Foi conhecendo e usando o 5D-NET que nós estudantes pensamos em sugestões que pudessem melhorar a utilização do mesmo. $\mathrm{O}$ blog poderia ser mais interativo, poderia ter uma sala de bate papo igual a do Facebook, poderia ter um notificador para saber quem comentou ou adicionou a gente. 


\section{APÊNDICE B - ENTREVISTA ADOLESCENTES COM LESÃO CEREBRAL}

Nome: LGLL - D110864

Unidade: BSB-LN

Entrevistador: Em sua opinião, para que serve o 5D-NET?

Entrevistado: Pra fazer o dever de casa e pesquisar altas coisas interessantes.

Entrevistador: Mas assim, o 5D-NET, você lembra do 5D-NET, quando você abre o labirinto, não aparece um negocinho para você colocar o seu nome e sua senha e logar, aí tem várias fotos, o pessoal postando fotos, então, para que você acha que serve aquilo?

Entrevistado: Para mostrar todas as fotos que teve.

Entrevistador: Mais alguma coisa? Você acha importante colocar as fotos?

Entrevistado: aham.

Entrevistador: Então tá, E o que você gosta e ver no 5D-NET?

Entrevistado: O jogo.

Entrevistador: Jogo? No 5D-NET? Não, assim, é que tem o labirinto e tem a 5D-NET, né? Aquele lugar que tem as fotos e nãnãnã e você pode adicionar amigos, então, o que você mais gosta de ver ali?

Entrevistado: As fotos.

Entrevistador: As fotos?

Entrevistado: aham.

Entrevistador: Fotos de que, mais ou menos?

Entrevistado: As fotos da pescaria.

Entrevistador: É mesmo, né? A nossa tarde da pescaria, foi legal né?

Entrevistado: Foi.

Entrevistador: O que mais?

Entrevistado: E faço amigos.

Entrevistador: Aham. Tem muitos amigos? Não? E por que você não disse antes?

Entrevistado: Eu esqueci.

Entrevistador: Pois é. E o que você gosta de postar no 5D-NET, o que você gosta de colocar lá?

Entrevistado: As fotos.

Entrevistador: Fotos? Você colocou da pescaria?

Entrevistado: Aham. 
Entrevistador: O que mais você colocou lá?

Entrevistado: Só.

Entrevistador: Da pescaria?

Entrevistado: É.

Entrevistador: E qual foi a cosa mais legal que você viu que alguém fez ou que você já fez no 5D-NET?

Entrevistado: Nada.

Entrevistador: Nada de legal você viu lá?

Entrevistado: A foto da pescaria e os moleques?

Entrevistador: Tem muito gente flamenguista na 5D-NET, você tem que ir lá e falar: "Olha, sou vascaíno, o Vasco é melhor".

Entrevistado: Sou eu.

Entrevistador: Pois é. E a coisa mais chata que você viu lá?

Entrevistado: O ladrão do peixe.

Entrevistador: rs.

Entrevistado: rs.

Entrevistador: O João Vítor postou as fotos dele?

Entrevistado: Pegando o meu peixe.

Entrevistador: Nossa!!! Aquele peixe era nosso! É, então, você entrou no 5D-NET desde que você chegou aqui, no SARAH?

Entrevistado: Aham.

Entrevistador: E você usa ele da mesma forma que você usava antes ou você mudou alguma coisa, você começou a fazer coisas diferentes?

Entrevistado: Mesmas coisas.

Entrevistador: Mesmas Coisas?

Entrevistado: Aham.

Entrevistador: Aí você posta fotos, adiciona amigos, o que você mais você faz?

Entrevistado: Não fiz amigos ainda não.

Entrevistador: Não fez amigos ué, mais é só chegar, né?

Entrevistado: É.

Entrevistador: Eu acho que você poderia postar uma foto do Vasco, porque ia dar muito polêmica.

Entrevistado: É, eu quero por.

Entrevistador: rs, eu acho que ia. E o que você acha, assim, que você podia mudar no 5D-NET, para ele ficar bem mais legal?

Entrevistado: Mais brincadeiras e menos videogame, mais computador. 
Entrevistador: Menos computador? No 5D-NET. Eu não entendi. No 5D-NET, naquele negócio onde a gente coloca fotos, o que você acha que podia mudar lá naquele negócio de colocar fotos, que você acha que seria legal?

Entrevistado: Nada.

Entrevistador: Nada? Tá bom do jeito que tá?

Entrevistado: É.

Entrevistador: Ah, então, tá. Acabou, viu como é rápido?

Entrevistado: Vi.

Entrevistador: Você lê o que os outros postam na 5D-NET?

Entrevistado: As vezes.

Entrevistador: E quando você lê o que o pessoal posta?

Entrevistado: Quando falam "oi, como você está".

Entrevistador: Entendi. Você lê as mensagens que mandam prá você?

Entrevistado: É.

Entrevistador: E o que você mais gosta de ler na 5D-NET?

Entrevistado: Do Vasco.

Entrevistador: Então seu eu postar umas coisas legais do Vasco, você vai ler e comentar?

Entrevistado: Sim.

Nome: DMC - D118379

Unidade: BSB-LN

Entrevistador: Qual seu nome?

Entrevistado: Diego Moreira de Carvalho

Entrevistador: Em sua opinião Diego, para que serve o 5D-NET?

Entrevistado: Que 5D-NET?

Entrevistador: Lembra aquele blog que a gente usa?

Entrevistado: Sim.

Entrevistador: Para que serve?

Entrevistado: Para mexer na internet mesmo, para saber sobre as coisas.

Entrevistador: Sabe aquele blog que fica lá dentro do labirinto? Você usa ele para que?

Entrevistado: É para melhorar a mente?

Entrevistador: Para que serve, na sua opinião? 
Entrevistado: Serve para melhorar o nosso, humm, hummm.

Entrevistador: A nossa o quê?

Entrevistado: A nossa inteligência.

Entrevistador: É o que você acha? Acha que é para melhorar a inteligência?

Entrevistado: É.

Entrevistador: O que você gosta de ver no 5D-NET?

Entrevistado: Mexer na internet, jogar, ver as coisas.

Entrevistador: O que você gosta de colocar ou de postar no 5D-NET?

Entrevistado: Eu nem postei ainda!

Entrevistador: Você nunca postou nada?

Entrevistado: Não

Entrevistador: Qual foi a coisa mais legal que você viu ou que fez no 5D-NET?

Entrevistado: Todas as coisas.

Entrevistador: Você costuma olhar o 5D-NET?

Entrevistado: Aham! Aham!

Entrevistado: Sempre e sempre?

Entrevistado: Mesmo.

Entrevistador: E teve alguma que você se lembre, que acha mais legal ou que achou mais chata?

Entrevistado: Acho que todos são legais.

Entrevistador: Teve alguma que você achou chata?

Entrevistado: Não.

Entrevistador: Você continua usando o 5D-NET como usava antes?

Entrevistado: Mais ou menos.

Entrevistador: Você usava muito antes ou não?

Entrevistado: Usava.

Entrevistador: Usava para que?

Entrevistado: É pra ka! Ka!, tipo ver o que o Organ vai fazer, vai mandar mensagem para nós.

Entrevistador: E hoje em dia, você usa menos?

Entrevistado: É.

Entrevistador: Por quê? Parou de usar?

Entrevistado: Parei. 
Entrevistador: Por quê?

Entrevistado: Não tenho muitas coisas que eu estou mexendo muito não.

Entrevistador: E você gostaria de mudar alguma coisa no 5D-NET para ele ficar mais legal?

Entrevistado: Sim.

Entrevistador: O que?

Entrevistado: Qualquer coisa.

Entrevistador: O que você faria se fosse mexer nele para ficar mais legal?

Entrevistado: Qualquer coisa. Qualquer coisa.

Entrevistador: Você mesmo, não tem nada que não sabia?

Entrevistado: Não.

Entrevistador: Você gosta de ver o que os outros postam na 5D-NET? O que as outras pessoas postam.

Entrevistado: Gosto.

Entrevistador: Todo tempo?

Entrevistado: De vez em quando.

Entrevistador: De vez em quando?

Entrevistado: Sim.

Entrevistador: É isso Diego, Obrigada.

Nome: FWSS - D123552

Unidade: BSB-LN

Entrevistador: Já ! Tá gravando, tá gravando... tá vendo alguma coisa aí, não?

Entrevistado: Hã?

Entrevistador: Tá ouvindo alguma coisa aí? Não?

Entrevistado: Hã? Credo, como assim?

Entrevistador: Então, eu vou falar algumas instruções. Entrevistador: Mateus Zigoto. Criança: Fábio William Sousa da Silva. Favor enviar para Ana Luisa. Então, Fábio, eu vou te fazer algumas perguntas sobre a 5D-NET. Você se lembra da 5D-NET?

Entrevistado: Lembro.

Entrevistador: Não precisa falar tão alto, você se lembra da 5D-NET? Já usou a 5DNET?

Entrevistado: Já não.... Já ! 
Entrevistador: Nunca usou a 5D-NET?

Entrevistado: Jáaaaaaaaaaaaaaaaaaaaaaaaa (palavrão).

Entrevistador: Então, é.... na sua opinião, para que serve a 5D-NET?

Entrevistado: Para ajudar as pessoas?

Entrevistador: Para ajudar as pessoas?

Entrevistado: É.

Entrevistador: A fazer o quê?

Entrevistado: Hã?

Entrevistador: Para ajudar... como que ajuda as pessoas?

Entrevistado: Ajudar, assim. Ah, eu não sei !!!

Entrevistador: Você não sabe para que serve a 5D-NET?

Entrevistado: Não, não, não.

Entrevistador: Nunca te perguntou sobre isso?

Entrevistado: NUNCA.

Entrevistador: Mas você já usou a 5D-NET?

Entrevistado: Já.

Entrevistador: E o que você gostou de ver na 5D-NET?

Entrevistado: Nada.

Entrevistador: Não gostou de nada?

Entrevistado: Jogos.

Entrevistador: De jogos?

Entrevistado: Aham.

Entrevistador: A 5D-NET....

Entrevistado: Essa porcaria aqui.

Entrevistador: Você sabe que a 5D-NET não é um labirinto né?

Entrevistado: Aham, eu já sei desde o primário. Eiiiiiiiiiiiiiiiiiiiiiiiii

Entrevistador: A 5D-NET é aquele negócio que parece orkut, que você bota fotinha, você bota foto do seu perfil, você já fez isso?

Entrevistado: Já na.

Entrevistador: Você nunca botou as fotos suas lá na net?

Entrevistado: ah é, eu estou .... olha, que bom... é a minha vóo0oooooooooooooooooooooo..............ó000000000000000000000000 oo 
Entrevistador: Pode falar mais baixo.

Entrevistado: Ai, ui, ai, ui, ui, ai, ui, ai, ui, aiiiiiiiiiiiiiiiiiiiaaaaaaaaaaa. (risadas). Olha, como que ele sabe que eu tô falando?

Entrevistador: Ele leu a sua voz e aí aparece aí do jeito que você está falando.

Entrevistado: Cadê?

Entrevistador: Aqui, ó. Aaaaaaaaaaaaaaaaaaaa tá vendo?

Entrevistado: tempo de duração?

Entrevistador: Tá acabando, tá acabando, a gente tem que acabar. Então, você já postou alguma coisa no 5D-NET? Você mesmo?

Entrevistado: Como assim, como?

Entrevistador: Sabe quando alguém te pergunta... ah....fala...posta ser alguma coisa no 5D-NET, posta a sua tarde, você já postou?

Entrevistado: O quê?

Entrevistador: Você já postou?

Entrevistado: Postou em quêeeeeeeeeeeeeeeeeeeeeeeeeeeeeeeeeeeeeeeeee?

Entrevistador: No 5D-NET.

Entrevistado: Como assim?

Entrevistador: É....por exemplo, você faz alguma coisa à tarde, tem foto sua da tarde, aí você vai lá no 5D-NET e coloca e comenta?

Entrevistado: Não.

Entrevistador: Nunca fez isso?

Entrevistado: Nuncaaaaa.

Entrevistador: Então..

Entrevistado: Nuncaaaaaaaaaaaaaaaaaaaaaaaaaaaaaaaaa (risadas). Que pô, isso é legal demais, mas como que [trecho inaudível]

Entrevistador: Vamos continuar...

Entrevistado: há?

Entrevistador: Você acha o 5D-NET legal, chato?

Entrevistado: Mais ou menos.

Entrevistador: Mais ou menos? Mas qual foi a coisa mais legal que você já viu na 5DNET?

Entrevistado: Jogos.

Entrevistador: Jogos?

Entrevistado: Jogos.

Entrevistador: Na 5D-NET? 
Entrevistado: E.

Entrevistador: Tipo qual jogo você já viu na 5D-NET?

Entrevistado: Ah, não sei. Oi, ei, ei ei ei isso tá gravando a minha voz ! (risos).

Entrevistador: Mas, assim, teve alguém que postou algum jogo no 5D-NET que você viu?

Entrevistado: Não, não vi não.

Entrevistador: Não viu? Mas você falou que tinha visto.

Entrevistado: Visto o quê?

Entrevistador: Jogos na 5D-NET.

Entrevistado: Ah, vi.

Entrevistador: Qual jogo que você viu lá?

Entrevistado: Ah, um bucado, homem aranha.

Entrevistador: Mas isso não é o labirinto?

Entrevistado: É.

Entrevistador: Então, mas a 5D-NET, que é onde está a sua foto...

Entrevistado: Sei.

Entrevistador: Você já viu alguma coisa legal lá?

Entrevistado: Não (risadas).

Entrevistador: Então, mas você já usava o 5D-NET. Você usa o 5D-NET desde quando?

Entrevistado: Desde o ano passado.

Entrevistador: Desde o ano passado? E você já postou alguma coisa lá? Não, né? Você já falou que não. Você gostaria de mudar alguma coisa na 5D-NET?

Entrevistado: Eu mudaria.

Entrevistador: O que você mudaria?

Entrevistado: Ah, eu mudaria as pessoas jogarem o que você quiser, pronto.

Entrevistador: Mas, e assim para postar alguma coisa?

Entrevistado: Como assim, sangue bom?

Entrevistador: Ah, vai acabar o tempo.

Entrevistado: ih, acabou? Ih, acabou. Vambora, tchau.

Entrevistador: Ah não, acabou não.

Entrevistado: Dez minuto? 
Entrevistador: Agora, atualizou ali. Eh, vocês já usaram o 5D-NET antes e agora você está usando o mesmo tanto? Você usava mais antes, está usando mais agora?

Entrevistado: Não, não estou mais usando nunca.

Entrevistador: Nunca mais usou?

Entrevistado: Nunca.

Entrevistador: Antes, você usava mais?

Entrevistado: Não.

Entrevistador: Você usava pouco.

Entrevistado: Usava pouco, né? Eu usava quando eu precisava.

Entrevistador: O que você precisava, quando te mandavam ou quando....

Entrevistado: Não.

Entrevistador: Você já quis entrar por conta própria no 5D-NET?

Entrevistado: Não.

Entrevistador: Por que não?

Entrevistado: O quêeeeeeeeeeeeeeeeeeeeeee

Entrevistador: É chato?

Entrevistado: Eu entrei só por causa do vídeo-game...... (risadas)... agora, você tá vendo o que que eu tô fazendo né? Hum.... ih, acabou a entrevista. Vambora, borá, todos já fora.

Entrevistador: Tá bom, então vamo lá.

Entrevistado: tchauuuuuuuuuuuuuuuuuuuuuuuuuuuuuuuuuuuu.

É pausa, meu.

Entrevistador: Você lê o que os outros postam na 5D-NET?

Entrevistado: Nunca li.

Entrevistador: E se eu postasse algo seu, você entraria pra ver?

Entrevistado: Aaaah... não!

Entrevistador: Ok, acabou a entrevista.

Obs: Apesar das minhas tentativas de fazê-lo separar a 5D-NET do Labirinto, o menino pareceu não compreender. Todas as vezes que respondia algo sobre a 5D-NET, parecia associar ao Labirinto. Num geral, pareceu conhecer muito pouco sobre a 5D-NET e não demonstrou interesse em fazer parte da rede social; contudo, no final, quando perguntei se se postasse algo dele se ele veria, ele ficou relutante. Acabou dizendo que não, mas pareceu que ficaria curioso e acabaria vendo. É uma boa tentativa para chama-lo para a atividade futuramente. 
Nome: LLCLS - D126028

Unidade: BSB-LN

Entrevistador: Léo, na sua opinião, para que serve o 5D-NET? Você sabe o que é o 5DNET?

Entrevistado: Não, não.

Entrevistador: Você não lembra o que que é? Aquele que posta as coisas.

Entrevistado: Não sei.

Entrevistador: Deixa eu te mostrar, então. Se eu te mostrar, você lembra?

Entrevistado: Há?

Entrevistador: Eu vou te mostrar o que é o 5D-NET para você lembrar, tá bom?

Entrevistado: Não, não quero. Não.

Entrevistador: Então, Léo, para que você acha que serve aquele negócio ali, o 5DNET? Na sua cabeça, para que você acha que serve?

Entrevistado: Eu não sei, já disse, que m....! Eu não gosto que você fica perguntando um monte de coisas chatas, não sei!

Entrevistador: Léo, assim não tá legal o seu comportamento. No que você viu ali na $5 \mathrm{D}$, Léo, o que você gostaria que tivesse lá?

Entrevistado: Não sei.

Entrevistador: Se você pudesse colocar alguma coisa na 5D, por exemplo, os seus vídeos de [trecho inaudível] de [trecho inaudível] aquela dança lá que eu esqueci o nome...

Entrevistado: Não sei.

Entrevistador: Mas se você pudesse, você gostaria de colocar ele para as outras pessoas verem?

Entrevistado: Não.

Entrevistador: Não gostaria?

Entrevistado: $\quad$...

Entrevistador: Do pouco que você lembra da 5D-NET, que você olhou ali agora, você consegue lembrar de alguma coisa que você achou mais legal? Por exemplo, a música que você viu com a Carol, aquilo foi legal?

Entrevistado:

Entrevistador: Não foi legal? Mas no dia você gostou?

Entrevistado: [trecho inaudível].

Entrevistador: Entendi. E de mais chato, você lembra alguma coisa que era mais sem graça e mais chato?

Entrevistado: ... 
Entrevistador: Você já tinha usado a 5D antes, Léo?

Entrevistado: Já.

Entrevistador: Já? Se lembra para quê?

Entrevistado: Para botar fotos do Flamengo.

Entrevistador: Ah, tá. E você acha que você está usando menos agora?

Entrevistado: Tô.

Entrevistador: Por que? Enjoou? Está chato, o que você acha?

Entrevistado: Chato.

Entrevistador: Chato? Você sabe por que que tá chato? Você nem imagina? Você acha que o que o pessoal está colocando lá é sem graça?

Entrevistado: Não.

Entrevistador: Não? Você queria mudar alguma coisa lá para ficar mais legal? Se tivesse alguma coisa, por exemplo, assim, ó, se tivesse alguma coisa sobre tal assunto, eu ia gostar de entrar mais, não tem nenhuma sugestão?

Entrevistado: Não.

Entrevistador: Não? Então, tá bom. Você lê o que os outros postam na 5D-NET?

Entrevistado: Não li.

Nome: MMC - D160020

Unidade - BSB-LN

Entrevistador: Na sua opinião, Maria, para que serve o 5D net?

Entrevistado: Serve para jogar, colocar fotos, gravar vídeos.

Entrevistador: E o que você gosta de ver lá no 5D net?

Entrevistado: Fotos, vídeos.

Entrevistador: E o que que você gosta de postar lá no 5D net?

Entrevistado: Pesquisa.

Entrevistador: Coloca fotos de quê?

Entrevistado: Da novela, da minha casa.

Entrevistador: E alguma coisa que você faz aqui?

Entrevistado: aham.

Entrevistador: Qual foi a coisa mais legal que você já viu no 5D net?

Entrevistado: Não sei.

Entrevistador: Não sabe? Como é que você entra na 5D net? 
Entrevistado: Você aperta a telinha e entra.

Entrevistador: O que você viu de mais chato no 5D net?

Entrevistado: Já.

Entrevistador: De mais legal, você acha que é o quê? As fotos que você falou e o de mais chato, você acha que é o quê? O que que você acha que é chato lá no 5D net?

Entrevistado: sei lá.

Entrevistador: Você não gosta ou você gosta?

Entrevistado: Eu gosto, eu só não sei a senha, eu tenho que achar.\}

Entrevistador: E você continua usando o 5D net que nem você usava no começo? Você usa o 5D net?

Entrevistado: Uso, só que o problema é que o meu 5D net não entra mais.

Entrevistador: Por que que não entra mais?

Entrevistado: Porque a senha não lembro.

Entrevistador: Mas quando entrava, você entrava bastante? Ou você não entra mais porque não tem mais uma senha?

Entrevistado: eu não tenho mais a senha.

Entrevistador: E o que que você gostaria de mudar lá no 5D net para ele ficar muito legal?

Entrevistado: Eu queria mudar que a gente podia colocar, sabe o facebook? Como um jogo.

Entrevistador: Nos jogos? Para jogar no 5D net? Mas a gente não tem o labirinto? O labirinto tem um monte de jogo para jogar.

Entrevistado: Eu queria que fosse um labirinto, quer dizer no 5D-NET.

Entrevistador: E aí você acha que foi legal o jogo. Por que que você queria jogo na 5D net? Para poder jogar com os outros pelo computador?

Entrevistado: Prá, sei lá.

Entrevistador: Então, tá bom. A gente terminou.

Entrevistado: nã nã nã......

Nome: JRS - D176571

Unidade: BSB-LN

Entrevistador: Então, Jefferson, na sua opinião, para que serve o 5D-NET?

Entrevistado: Bom serve para tu entrar no teu site e também pra tu ficar conversando com amigos também em depoimento, essas coisas. 
Entrevistador: E tem mais alguma função? Quando você entra no 5D-NET o que você faz lá?

Entrevistado: Eu entro nos meus amigos e olho o que quê tem, foto.

Entrevistador: Normalmente tem o quê? Foto? O que mais?

Entrevistado: Tem depoimento assim que escreve pra eles.

Entrevistador: Ah, legal. E o que você gosta de ver na 5D-NET?

Entrevistado: Gosto de ver, só foto só que eu gosto, ver mais nada. Eu mando recado, também.

Entrevistador: Você já viu alguma outra coisa sem ser foto?

Entrevistado: Não.

Entrevistador: Lembra que uma vez a jogou?

Entrevistado: Não.

Entrevistador: Um jogo que era no 5D-NET e o Maicon apostou charada também?

Entrevistado: $\tilde{A} h$.

Entrevistador: Então, você gostou de ver esse jogo? A charada?

Entrevistado: $\tilde{A} h$, gostei.

Entrevistador: Gostou? Mas o que você gosta mais de ver?

Entrevistado: É charadas dos estudantes que ele colocou foi o que é que é, também.

Entrevistador: Hum, legal. E o que você gosta de colocar no 5D-NET, no seu 5DNET?

Entrevistado: É de postar foto, também, só. Mais fotos.

Entrevistador: Você gosta de colocar fotos, né?

Entrevistado: $\tilde{A} h$.

Entrevistador: Mas você colocaria alguma música? Se você fosse colocar alguma coisa além da foto?

Entrevistado: Eu não colocaria não.

Entrevistador: O que seria?

Entrevistado: Eu nunca coloquei música não.

Entrevistador: Mas você acha que seria uma boa ideia?

Entrevistado: $\tilde{A} h$.

Entrevistador: Sim, tá. E qual foi a coisa mais legal que você viu ou fez no 5D-NET? Entrevistado: Foi o quê, que mais posto em charadas, só isso que eu vi que tava bom.

Entrevistador: Explica pra gente, como é que era esse que é o que é? 
Entrevistado: Tinha várias coisas para nóis acertar, aí nóis colocava lá se tava certa ou errada, assim, pra ver o que era, era homem, era tipo animal assim, pra nóis colocar.

Entrevistador: E você acha que seria mais interessante se mais pessoas colocassem charadas ao invés de fotos, por exemplo?

Entrevistado: $\tilde{\text { Âh. }}$

Entrevistador: Sim?

Entrevistado: $\tilde{\text { Âh. }}$

Entrevistador: E como é que poderia fazer para as pessoas colocarem mais charadas?

Entrevistado: Ah, não sei não.

Entrevistador: Se você colocasse, por exemplo, para as outras pessoas verem, não seria legal?

Entrevistado: $\tilde{A}$.

Entrevistador: Então. E qual foi a coisa mais chata que você viu no 5D-NET?

Entrevistado: Foi, que eu não gostei mais, foi, como é mesmo o nome, não lembro não. Não, tudo lá eu gosto, nenhuma coisa eu acho ruim não.

Entrevistador: É?

Entrevistado: É, eu gosto.

Entrevistador: Mas, por exemplo, quando as pessoas colocam fotos, ai você quer comentar, não comenta, porquê você acha legal, acha chato?

Entrevistado: Não, chato não, acho legal, porque eu não escrevo mesmo, eu não tenho pra falar.

Entrevistador: Mas você não acha que as pessoas achariam legal que você falasse pra elas?

Entrevistado: $\tilde{\text { Âh. }}$

Entrevistador: É, então. E você acha que você continua usando a 5D-NET como antes? Por exemplo, antes você usava mais e agora menos ou o contrário?

Entrevistado: Não, tá a mesma coisa.

Entrevistador: Tá a mesma coisa, né? E tem alguma coisa que você gostaria de mudar na 5D-NET, para que ele fique mais legal?

Entrevistado: Tem, mas, tem um monte de coisa, mas eu não sei ainda não, tem um monte coisa para colocar, mas eu não aprendi ainda, não sei.

Entrevistador: Mas não que você devesse colocar, mas que outra pessoa colocasse. Sugere uma ideia aí, o que a gente poderia colocar para ficar mais legal?

Entrevistado: Vídeo assim, charadas, também, fotos.

Entrevistador: Vídeo né. 
Entrevistado: Hum, hum.

Entrevistador: Mas você acha, por exemplo, hoje a gente descobriu que tem pessoas que podem deixar mensagens para você sem ser no arquivo.

Entrevistado: Hum, hum.

Entrevistador: Você acha que teria algo mais além dessas mensagens que as pessoas podem colocar?

Entrevistado: Sim.

Entrevistador: Ficaria mais legal?

Entrevistado: É.

Entrevistador: O quê?

Entrevistado: Ficaria, só as fotos mesmo.

Entrevistador: Colocasse mais foto né?

Entrevistado: Ãh, é.

Entrevistador: Então tá bom, acho que é isso. Tem mais alguma coisa que você quer falar sobre o 5D-NET.

Entrevistado: Não.

Entrevistador: Não?

Entrevistado: Então tá bom. Você lê o que os outros postam na 5D-NET?

Nome: TNM - D180655

Unidade: BSB-LN

Entrevistador: Hoje a gente vai falar sobre 5D-NET você conhece?

Entrevistado: Sim.

Entrevistador: Na sua opinião, para que serve a 5D-NET?

Entrevistado: Para se comunicar com outras pessoas.

Entrevistador: Quem são essas outras pessoas?

Entrevistado: As pessoas da 5D.

Entrevistador: Então, você gosta de ver o 5D?

Entrevistado: Sim.

Entrevistador: O que você gosta de postar, de colocar na 5D?

Entrevistado: Fotos, vídeos, só.

Entrevistador: Qual foi a coisa mais legal que você viu ou que foi fez na 5D? Alguma coisa bem divertida que você viu lá.

Entrevistado: A coisa mais legal que eu postei no 5D foi a foto do Djokovic. 
Entrevistador: Quem é o Djokovic?

Entrevistado: É um jogador de tênis muito famoso.

Entrevistador: E porque que esta é a mais legal?

Entrevistado: Porque na foto que eu postei ele está muito esticado.

Entrevistador: Agora a gente vai mudar um pouco. Vou perguntar para você qual foi a coisa mais chata que você já viu ou que você postou no 5D?

Entrevistado: Não existe nenhuma coisa chata no 5D, porque as pessoas que postam, elas pensam antes de postar, por isso não tem coisas chatas, só tem coisas legais.

Entrevistador: [trecho inaudível] diferentes dessas outras redes sócias? Você acha?

Entrevistado: Acho.

Entrevistador: Agora nossa próxima pergunta vai ser: você continua usando a 5D como usava antes no começo?

Entrevistado: Não, porque nas redes sociais a gente pode pesquisar coisas dos famosos, dos artistas e na 5D-NET não, só pode se comunicar com seus colegas.

Entrevistador: Isso fez com que você usasse menos o 5D?

Entrevistado: Não.

Entrevistador: Você falou que não está usando do mesmo jeito que você usava antes, mas você tá usando diferente como? Mais, menos, como que você mudou o uso do 5D? Você continua usando a 5D como antes?

Entrevistado: Sim. Eu estou usando mais o 5D porque tem muitas coisas legais para fazer, tem como mandar recados, postar coisas dos famosos, vídeos e muitas coisas interessantes, por isso eu estou usando mais.

Entrevistador: Agora uma pergunta bem legal, o que você gostaria de mudar no 5D para que ele fique mais legal ainda, alguma coisa que ache que poderia ser diferente no 5D?

Entrevistado: Não precisa mudar nada no $5 \mathrm{D}$, porque já tem tudo que precisa e por isso não tem que ser mudado, está muito legal do jeito que está.

Entrevistador: Muito obrigada pela sua ajuda na entrevista, foi ótimo falar com você Thais, tchau.

Entrevistado: tchau.

Entrevistador: Tem mais alguma coisa que você queira dizer sobre o 5D?

Entrevistado: Não.

Entrevistador: Então tá bom. Você lê o que os outros postam na 5D-NET?

Entrevistado: Algumas vezes, sim. 
Nome: PVSM - D181322

Unidade: BSB-LN

Entrevistador: Pedro, na sua opinião, para que serve a 5D-NET?

Entrevistado: Pra brincar.

Entrevistador: Mas você brinca de quê na 5D-NET, que é aquele site que fica do lado do labirinto?

Entrevistado: Faço massinha, jogo videogame, às vezes quando não tem nada eu mexo no computador, brinco de tudo.

Entrevistador: Mas a gente está falando daquele lá do cantinho, aí onde você faz a massinha, usa o computador é o Labirinto. Você conversa com seus amigos na 5D-NET?

Entrevistado: Não.

Entrevistador: Não?

Entrevistado: Sim.

Entrevistador: Sim? Então você conversa com os amigos. E o que você gosta de vê na 5D-NET?

Entrevistado: Nada, não tem nada pra vê.

Entrevistador: Não tem nada, você nunca entrou na página de algum amigo?

Entrevistado: Sim.

Entrevistador: Sim? E o que você gosta de fazer quando você vai na página do amigo?

Entrevistado: Nada.

Entrevistador: Só vê?

Entrevistado: Só vê.

Entrevistador: O que você gosta de colocar ou postar no 5D-NET?

Entrevistado: Mandar mensagem pro Og@MM..

Entrevistador: Pelo 5D-NET você manda? Você não manda pelo correio não?

Entrevistado: É pelo correio.

Entrevistador: E no 5D-NET você conversa com seus amigos?

Entrevistado: Humm humm.

Entrevistador: Você gosta?

Entrevistado: Mais ou menos.

Entrevistador: Mais ou menos? Qual foi a coisa mais legal que você viu ou fez no 5DNET?

Entrevistado: Nada. 
Entrevistador: Você nunca postou nenhuma foto?

Entrevistado: Sim.

Entrevistador: Qual?

Entrevistado: Eu tirei a foto [trecho inaudível] lago.

Entrevistador: Você gostou?

Entrevistado: Gostei.

Entrevistador: E as pessoas comentaram sua foto, você viu?

Entrevistado: Sim.

Entrevistador: E recentemente você postou alguma coisa?

Entrevistado: Que isso que você falou?

Entrevistador: Hoje em dia, assim, semana passada, você postou alguma coisa?

Entrevistado: Não.

Entrevistador: E aquela foto das massinhas que você tirou?

Entrevistado: Sim.

Entrevistador: Você gostou de fazer?

Entrevistado: Não.

Entrevistador: Não?

Entrevistado: Sim.

Entrevistador: Ah tá. E o de mais chato que você viu no 5D-NET? Algo assim que você não gostou. Você viu assim, ah não, isso é muito chato. [trecho inaudível] Pode ser o que você viu de outro blog, de outro [trecho inaudível], de outra criança.

Entrevistado: Eu não sei o que falar.

Entrevistador: Não sabe? Então você nunca viu nada de chato no 5D-NET?

Entrevistado: Não.

Entrevistador: E o que você gostaria de mudar no 5D-NET, para ficar assim bem melhor?

Entrevistado: O Og@mm para ver ele.

Entrevistador: [trecho inaudível] que alguém tivesse uma página do 5D-NET, você queria?

Entrevistado: Sim.

Entrevistador: E o que mais de que você gostaria que tivesse, além do Og@mm? Você lembra 5D-NET é um blog, que a gente posta as fotos, tem as mensagens, o que você acha também que poderia ter no 5D-NET, comparando com outras redes sociais como o Facebook, Orkut? 
Entrevistado: Facebook.

Entrevistador: Não, mas Facebook é um tipo, o 5D-NET é o nosso facebook. O que você acha que poderia ter?

Entrevistado: Fotos dos nossos amigos para falarem com ele um monte de palavras, [trecho inaudível] e falar com eles.

Entrevistador: Ter um chat então que você tá falando?

Entrevistado: Como é o nome daquilo, "messeger" sei lá, que a gente pode pôr aqueles desenhinhos.

Entrevistador: Ah, emotions. Você gostou daquelas carinhas?

Entrevistado: É, aquelas carinhas, aquelas [trecho inaudível].

Entrevistador: Você queria que tivesse um chat para você conversar com seus amigos on-line?

Entrevistado: Sim.

Entrevistador: Mas alguma coisa ou só isso?

Entrevistado: Ia ser muito legal que tivesse isso.

Entrevistador: Que tivesse o chat? Então você queria só isso?

Entrevistado: Só isso.

Entrevistador: Tem mais alguma coisa que você quer falar?

Entrevistado: Não.

Entrevistador: Nada?

Entrevistado: Não.

Entrevistador: Então, obrigada!

Nome: DLCM - D184419

Unidade: BSB-LN

Entrevistador: Qual o seu nome Débora?

Entrevistado: Débora.

Entrevistador: Débora de que?

Entrevistado: Costa Martins.

Entrevistador: Débora Costa Martins?

Entrevistado: Débora Lorrane Costa Martins de Souza.

Entrevistador: Débora Costa Martins de Souza? Isso?

Entrevistado: Não, Débora Lorrane. 
Entrevistador: Oi?

Entrevistado: Débora Martins.

Entrevistador: Débora Martins de Souza. Na sua opinião, para que serve o 5D-NET?

Entrevistado: Não sei.

Entrevistador: Oi?

Entrevistado: Não sei.

Entrevistador: Você não sabe?

Entrevistado: Não.

Entrevistador: Você se lembra do 5D-NET?

Entrevistado: Não.

Entrevistador: Oi?

Entrevistado: Não.

Entrevistador: Não? Aquele programinha que a gente entrou hoje no computador, que tem uma foto bem bonita.

Entrevistado: Não sei não.

Entrevistador: Não sabe? Aquele que tem a sua foto antiga, que você falou?

Entrevistado: Não sei.

Entrevistador: Você não lembra ou não sabe?

Entrevistado: Não lembro.

Entrevistador: Não lembra?

Entrevistado: Não, não lembro mais.

Entrevistador: Um programa que a gente colocava algumas fotos. As fotinhas.

Entrevistado: Ah.

Entrevistador: Alguns vídeos. Colocava sua foto, seu vídeo, e o que mais?

Entrevistado: Não sei.

Entrevistador: O que dá para fazer lá, no 5D-NET?

Entrevistado: Não sei.

Entrevistador: Ah?

Entrevistado: Não sei.

Entrevistador: Não sabe?

Entrevistado: Não.

Entrevistador: O que a gente fazia?

Entrevistado: Ah, não. 
Entrevistador: Não sabe? Olha, eu mandei um mensagem pra você. Você lembra?

Entrevistado: Eu lembro.

Entrevistador: Lembra? Então serve pra quê?

Entrevistado: Pra mim.

Entrevistador: Pra você?

Entrevistado: É sim.

Entrevistador: O que você gosta de ver no 5D-NET?

Entrevistado: Minhas fotos.

Entrevistador: Suas fotos.

Entrevistado: Minhas fotos, meu vídeos.

Entrevistador: Seus vídeos. E só?

Entrevistado: E só.

Entrevistador: Nada? Tá bom do jeito que tá?

Entrevistado: É.

Entrevistador: O que você gosta de colocar, postar no 5D-NET?

Entrevistado: Ah, não sei.

Entrevistador: O que você gosta de colocar lá pro pessoal ver, para todo mundo ver?

Entrevistado: $\mathrm{Ah}$, não sei não.

Entrevistador: Você coloca alguma coisa na 5D-NET?

Entrevistado: Coloco minhas fotos e meus vídeos.

Entrevistador: Você coloca suas fotos e seu vídeo. E você vê as fotos e os vídeos de outras pessoas?

Entrevistado: Não.

Entrevistador: Você não vê? Você só olha as suas?

Entrevistado: Hum, hum.

Entrevistador: Nem comenta? Você comenta de alguém?

Entrevistado: Não.

Entrevistador: Qual foi a coisa mais legal que você viu ou fez na 5D-NET?

Entrevistado: Colocar, colocar as minhas fotos.

Entrevistador: Colocar as suas fotos?

Entrevistado: Colocar meus vídeos.

Entrevistador: Colocar seus vídeos? Só?

Entrevistado: Só. 
Entrevistador: E alguém fez algum comentário no seu vídeo?

Entrevistado: Só você.

Entrevistador: Só eu, ah é? E aquele tanto de gente lá? Tava fazendo o quê naquela fotinha? Você lembra?

Entrevistado: Não.

Entrevistador: Não? O que é que você acha que tem de mais chato lá?

Entrevistado: Deixa ver. Deixa eu ver.

Entrevistador: Tá pensando?

Entrevistado: Hum, hum.

Entrevistador: Ah, vou esperar então. Você quer que eu repita a pergunta?

Entrevistado: Não.

Entrevistador: Não?

Entrevistado: Não sei.

Entrevistador: Você continua usando o 5D-NET como antes?

Entrevistado: Âh, ah.

Entrevistador: Âh? Como era que você usava antes?

Entrevistado: Não sei.

Entrevistador: Você usava muito? Não?

Entrevistado: Não.

Entrevistador: E você gosta de usar o 5D-NET?

Entrevistado: Eu gosto.

Entrevistador: Você gosta?

Entrevistado: Hum, hum.

Entrevistador: E você usa muito ou pouco?

Entrevistado: Pouco.

Entrevistador: Pouco? Por que?

Entrevistado: Não gosto de ficar olhando toda hora não.

Entrevistador: Você não gosta de ficar olhando toda hora?

Entrevistado: Não.

Entrevistador: Porque?

Entrevistado: Porque é muito chato.

Entrevistador: É muito chato?

Entrevistado: Ficar olhando, só olhando, só olhando. 
Entrevistador: Ficar olhando todo dia, toda hora, é muito chato?

Entrevistado: É.

Entrevistador: É. O que você acha que poderia mudar para ficar mais legal?

Entrevistado: Colocar a foto de um "paiaço".

Entrevistador: Colocar a foto de um palhaço? O que mais?

Entrevistado: Papai Noel.

Entrevistador: Papai Noel.

Entrevistado: Eu acho, não sei.

Entrevistador: O que você gosta de fazer que você acha que poderia ser colocado lá e que ficaria legal?

Entrevistado: Minha foto, minha foto vestida de "paiaço".

Entrevistador: Sua foto vestida de palhaço. O que você está fazendo?

Entrevistado: Nada.

Entrevistador: Tá apertando os botões, né?

Entrevistado: Hum.

Entrevistador: Não pode, senão vai sair lá, você não acha, oh? Tá gravando a nossa voz, oh nossa voz aqui.

Entrevistado: Ah.

Entrevistador: Ãh?

Entrevistado: Âh.

Entrevistador: Você lê o que os outros postam na 5D-NET?

Entrevistado: Hum....não.

Entrevistador: Por quê?

Entrevistado: É difícil algumas....

Entrevistador: Você tem mais alguma coisa para falar do 5D-NET?

Entrevistado: Não. Nada.

Entrevistador: Nada? Então tá bom, vamos finalizar a entrevista.

Nome: FBS - D194935

Unidade: BSB-LN

Entrevistador: Fê, na sua opinião, pra que que serve o 5D-NET?

Entrevistado: Ah, pra brincar?

Entrevistador: Pra brincar? E como você brinca? O que você faz no 5D-NET?

Entrevistado: Nós fala com as pessoas, nós não fala com as pessoas? 
Entrevistador: Fala. Você não deixa mensagens?

Entrevistado: Nós fala com as pessoas, [trecho inaudível] mensagens, só isso.

Entrevistador: E o que você gosta de vê no 5D-NET?

Entrevistado: Eu gosta de vê as mensagens, meus amigos que tão acessando. Só.

Entrevistador: O que você geralmente vê no 5D-NET? Você pode ver foto, né?

Entrevistado: Posso, mensagens.

Entrevistador: E dessas coisas todas que você mais gosta de ver?

Entrevistado: Mensagens.

Entrevistador: Mensagens? O que as pessoas comentam pra você, é isso?

Entrevistado: Comentários.

Entrevistador: O que você mais gosta de postar no 5D-NET, pras pessoas verem?

Entrevistado: Fotos.

Entrevistador: Fotos? Você já colocou vídeos?

Entrevistado: Não.

Entrevistador: O que mais a gente pode colocar? Áudio, também. Você já colocou.

Entrevistado: Não.

Entrevistador: Não? Aquele programinha que a gente entrou hoje no computador, que tem uma foto bem bonita.

Entrevistado: Não sei não.

Entrevistador: Só colocou fotos? É o que você mais gosta de colocar. Você gosta de comentar os 5D-NET dos outros?

Entrevistado: Gosto.

Entrevistador: Você comenta?

Entrevistado: Hãã?.

Entrevistador: Qual foi a coisa mais legal que você viu o que você fez no 5D-NET? Uma coisa que você viu e disse: "Nossa, que legal. Que interessante".

Entrevistado: Um comentário de uma pessoa.

Entrevistador: Como foi, vc lembra?

Entrevistado: Não. Foi no começo deste ano, ai.

Entrevistador: Mas você lembra qual foi a foto que você colocou que a pessoa comentou?

Entrevistado: Acha que foi. Hãã,

Entrevistador: Qual foi a foto?

Entrevistado: Foi foto do futebol. 
Entrevistador: O que a pessoa comentou que você gostou?

Entrevistado: Eu não lembro.

Entrevistador: Não se lembra? Porque você gostou muito então?

Entrevistado: É porque eu gostei. Mas não me lembro.

Entrevistador: Você gostou da pessoa ter comentado. E a coisa mais chata que você viu que você fez no 5D-NET? Nossa, que chato isso?

Entrevistado: Nada.

Entrevistador: Não teve nada? Não teve nenhuma figura que alguém postou que você não gostou? Alguma foto? Não?

Entrevistado: Não.

Entrevistador: Você acha que você continua usando o 5D-NET como você usava antes,

Entrevistado: Hãhã. no ano passado, por exemplo?

Entrevistador: Você sempre entra no 5D-NET?

Entrevistado: Não.

Entrevistador: E antes, você sempre entrava?

Entrevistado: Ahã.

Entrevistador: Então você acha que está usando da mesma forma?

Entrevistado: Ahã.

Entrevistador: Então tá. Outra coisa: o que você gostaria de mudar no 5D-NET para que ele fique mais legal?

Entrevistado: Colocar jogos no 5D-NET.

Entrevistador: Nada? Tá bom do jeito que tá?

Entrevistado: É.

Entrevistador: Jogos? Que tipo de jogos?

Entrevistado: Não sei, qualquer jogo legal.

Entrevistador: Você tem alguma ideia?

Entrevistado: Não. Tenho.

Entrevistador: Fala então.

Entrevistado: Banco imobiliário, detetive

Entrevistador: Hum. legal. Pra jogar no computador mesmo?

Entrevistado: É. 
Entrevistador: Porque aqui já tem né? Já tem jogo de tabuleiro no computador. Então tá. Tem mais alguma ideia de coisa legal pra mudar, pra ficar muito legal o 5D-NET?

Entrevistado: Não

Entrevistador: Não? Então tá bom. É isso. Você lê o que os outros postam na 5DNet?

Entrevistado: humm rumm

Entrevistador: Por quê?

Entrevistado: Mas não tudo. É bom. Porque eu gosto. Leio os comentários, mas não entro nas fotos antigas. Não leio o quadro de mensagem.

Nome: ASS - D148584

Unidade: BSB-LN

Entrevistador: Para que serve o 5D-NET?

Entrevistado: Não sei.

Entrevistador: Você usa o 5D-NET?

Entrevistado: Uso.

Entrevistador: Você usa ele pra quê?

Entrevistado: Não sei.

Entrevistador: Você posta foto?

Entrevistado: Posto.

Entrevistador: Posta atividade?

Entrevistado: hummm.

Entrevistador: Tá.

Entrevistador: O que você gosta de vê lá no 5D-NET?

Entrevistado: Vídeos, fotos.

Entrevistador: Dos outros estudantes, só daqui de Brasília ou?

Entrevistado: Só.

Entrevistador: Só?

Entrevistado: uhum.

Entrevistador: O que você gosta de colocar e de postar lá no 5D-NET? Você posta alguma coisa?

Entrevistado: Desafio.

Entrevistador: Posta desafio? Você posta fotos?

Entrevistado: Não. 
Entrevistador: Posta?

Entrevistador: Qual foi a coisa mais legal que você viu ou que você fez no 5D-NET? Alguma foto, alguma atividade?

Entrevistado: Não.

Entrevistador: Não? E mais chata?

Entrevistado: Nada.

Entrevistador: Nada?

Entrevistado: Nada, nada.

Entrevistador: Quando você entrou aqui, você usava o 5D-NET mais do que antes, mais do que agora?

Entrevistado: Não.

Entrevistador: Você usa o mesmo tanto de tempo que usava antes?

Entrevistado: uhum.

Entrevistador: Você gosta de usar?

Entrevistado: Gosto.

Entrevistador: Você gostaria de mudar alguma coisa no 5D-NET, para ele ficar mais legal?

Entrevistado: Não.

Entrevistador: Você acha ele assim legal?

Entrevistado: uhum.

Entrevistador: Cocê acha ele fácil de mexer?

Entrevistado: Acho.

Entrevistador: É? Sabe mexer em tudo?

Entrevistado: Quase.

Entrevistador: Sempre usa o 5D-NET todo dia?

Entrevistado: Todo dia não.

Entrevistador: Não? Mas quase sempre? E você não sabe para que serve?

Entrevistado: Não.

Entrevistador: Nem que você acha para que serve?

Entrevistado: Não.

Entrevistador: Não?

Entrevistado: Não.

Entrevistador: Tá bom. Você lê o que os outros postam na 5D-NET?

Entrevistado: Não, não interessa muito. 
Nome: MAR - D199642

Unidade: BSB-LN

Entrevistador: Matheus, na sua opinião, para que serve o 5D-NET?

Entrevistado: Pa falar um com outro.

Entrevistador: Só pra falar um com outro, o que mais você faz lá?

Entrevistado: Postar foto.

Entrevistador: Você gosta de colocar foto lá? Você coloca muito?

Entrevistado: Gosto.

Entrevistador: O que você mais gosta de ver no 5D-NET?

Entrevistado: Éééé, vejo fotos.

Entrevistador: E o que você gosta de colocar lá no 5D-NET?

Entrevistado: Foto.

Entrevistador: Só foto? Você gosta de escrever?

Entrevistado: Escrever, vídeo, foto.

Entrevistador: Qual foi a coisa mais legal que você viu ou você fez no 5D-NET?

Entrevistado: Postar foto.

Entrevistador: Qual foto foi a mais legal? Você lembra?

Entrevistado: Lembro.

Entrevistador: Qual?

Entrevistado: Uma que num quadro, aí eu botei no meu 5D-NET.

Entrevistador: E qual foi a coisa mais chata que você fez no 5D-NET?

Entrevistado: Nada.

Entrevistador: Nada foi chato? Você usava 5D-NET muito antes, você usa ele muito agora, como é que é?

Entrevistado: Mais ou menos.

Entrevistador: Você usava mais antes?

Entrevistado: Mais ou menos.

Entrevistador: Antes você usava mais?

Entrevistado: Usava mais.

Entrevistador: E agora?

Entrevistado: De vez em quando. 
Entrevistador: Porque só de vez em quando?

Entrevistado: Porque eu só vejo mais fotos que eu postei.

Entrevistador: E o que você queria mudar no 5D-NET, para que ele fique mais legal?

Entrevistado: Mudar opinião.

Entrevistador: Mudar o quê?

Entrevistado: Mudar, botar, voltar, postar amigo.

Entrevistador: Ah, tá. Você quer falar mais alguma coisa?

Entrevistado: Quero.

Entrevistador: Pode falar.

Entrevistado: Oi, tchau.

Entrevistador: Então tá bom.

Nome: GHBC - D200864

Unidade: BSB-LN

Entrevistador: Em sua opinião Geovane, para que serve o 5D-NET?

Entrevistado: Para postar fotos

Entrevistador: Para postar fotos. E o que mais?

Entrevistado: Para mostrar todas as fotos que teve.

Entrevistador: Mais alguma coisa? Você acha importante colocar as fotos?

Entrevistado: Mandar mensagem para o Ogan.

Entrevistador: Mandar mensagem para o Ogan, mas mandar mensagem para o Ogané o labirinto né? O 5D-NET dá para você mandar mensagem para outros colegas da 5D.

Entrevistador: Você gosta de ver fotos/vídeos, o que você gosta de ver no 5D-NET?

Entrevistado: Fotos dos amigos.

Entrevistador: O que você gosta de colocar ou postar no 5D-NET?

Entrevistado: Fotos de pescaria e de basquete.

Entrevistador: Qual foi a coisa mais legal que você viu ou fez no 5D-NET? E a mais chata.

Entrevistado Mais boa, boa! Mais legal? Jogar futebol de botão.

Entrevistador: O que você achou mais legal no 5D-NET de fazer?

Entrevistado: É. 
Entrevistador: E de mais chato?

Entrevistado: Ai! Meus Deus! Jogar, jogar, jogar, ai! Jogar, jogar, jogar! Jogar, jogar, jogar!

Entrevistador: No 5D-NET não gosta de jogar?

Entrevistado: Ah! É, também gosto de assistir música.

Entrevistador: Pedido de música? E de mais chata? O que você acha mais chata na 5DNET?

Entrevistado: Ficar vendo vídeo sem graça.

Entrevistador: Você continua usando o 5D-NET como antes? Você usa muito o 5DNET? ou não?

Entrevistado: Sim, eu uso o 5D-NET.

Entrevistador: Você continua usando?

Entrevistado: Contínuo.

Entrevistador: O que você gostaria de mudar no 5D-NET para que ele fique mais legal?

Entrevistado: Ih! Ih! Peraí. Não sei.

Entrevistador: Não sabe? O que você quer mudar no 5D-NET, ou não quer mudar nada?

Entrevistado: Nada.

Entrevistador: Eu não mudaria nada no 5D-NET não!

Entrevistado: Eu não mudaria nada no 5D-NET não. O quem está falando agora!

Entrevistador: Você leu o que os outros postam no 5D-NET?

Entrevistado: Não, não leio.

Entrevistador: Não leu o que os outros postam, por quê?

Entrevistado: Não, eu acho que não. Sei lá. Sei não!

Entrevistador: Você costuma usar muito o 5D-NET?

Entrevistado: Ah! Veiô, eu uso muito.

Nome: BCC - G001294

Unidade: Rio de Janeiro

Entrevistador: Vamos conversar um pouquinho? Vamos? Pode ser?

Entrevistado:

Entrevistador: Então, assim, a gente vai conversar sobre o 5DNET, como eu te falei. Aí eu queria saber assim, sua opinião para que serve o 5DNET? O que você acha? O que você pensa?

Entrevistado: Para mandar recado. 
Entrevistador: Que mais?

Entrevistado: Pra postar foto.

Entrevistador: Tem mais alguma coisa que você pensa, que você faz?

Entrevistado: Publicar.

Entrevistador: Publicar, ah, legal! Tem mais alguma função assim que você vê, que serve para alguma coisa? Assim sem ser essas que você já falou?

Entrevistado: Jogar.

Entrevistador: Para jogar, legal, e que quando você entra no 5DNET o que você gosta de ver? O que vem assim na sua cabeça, o que você gosta de ver?

Entrevistado: Os comentários.

Entrevistador: Os comentários? De que?

Entrevistado: De alguma coisa nessa questão.

Entrevistador: Por exemplo, assim, uma foto, o que você acha?

Entrevistado: É.

Entrevistador: E aquele recadinho que aparece no canto? Você sabe? Você já reparou nesse?

Entrevistado: Não.

Entrevistador: Que aparece assim no cantinho direito, que, às vezes dá para mandar individual?

Entrevistado: Não.

Entrevistador: Não? E quando você entra assim, o que você gosta de postar, de colocar? Você costuma entrar no 5DNET?

Entrevistado: Às vezes.

Entrevistador: Às vezes, e quando você entra, você entra mais para olhar ou costuma colocar alguma foto, publicar ou só escrever nas fotos de outra pessoa?

Entrevistado: $\mathrm{Eu}$ às vezes escrevo.

Entrevistador: Escreve?

Entrevistado: Escrevo.

Entrevistador: Mas você coloca, você tem o hábito de postar alguma coisa?

Entrevistado: Não.

Entrevistador: Vídeo, não?

Entrevistado: Não.

Entrevistador: Não costuma colocar não? E você lê o que os outros postam na 5DNET?

Entrevistado: Leio. 
Entrevistador: De todo mundo assim ou prefere ler de alguém assim específico:

Entrevistado: Não, leio de todo mundo.

Entrevistador: De todo mundo? E quando você olha assim, você sabe que está escrevendo na página de alguém conhecido? Se é daqui do Rio ou se é de Brasília?

Entrevistado: [trecho inaudível] conheço.

Entrevistador: Quê?

Entrevistado: Não conheço.

Entrevistador: Não conhece?

Entrevistado: Não.

Entrevistador: Mas nem quando é alguém aqui do Rio, você olha, ah vou postar uma foto no, vou comentar o 5DNET da Entrevistador. Você faz isso?

Entrevistado: [trecho inaudível] conheço [trecho inaudível] foto.

Entrevistador: O quê?

Entrevistado: Hoje eu conheço pela sua foto.

Entrevistador: Ah, já conhece pela foto, aí você entra, é isso?

Entrevistado: É.

Entrevistador: E o que você acha que é a coisa mais legal que você já viu ou fez no 5DNET? Pode pensar, assim pode ser o dia em que você colocou uma foto ou no dia em que você comentou, viu...

Entrevistado: Legal postar foto, comentar...

Entrevistador: E você lembra de algum caso específico, de alguma foto que você viu, que você comentou, que você achou muito legal, que te vem na sua memória esse dia. Tem alguma lembrança assim?

Entrevistado: Tem, mas eu não me lembro não.

Entrevistador: Não tem problema, se não lembrar não tem problema.

Entrevistado: Não me lembro.

Entrevistador: Se não lembrar, não tem problema. Lembra de alguma situação assim legal que estava com alguém e resolveu entrar no 5DNET?

Entrevistado: Não.

Entrevistador: E você lembra de alguma coisa chata que você viu ou fez no 5DNET? Entrevistado: Quê?

Entrevistador: Alguma coisa chata, você acha alguma coisa chata no 5DNET?

Entrevistado: Não.

Entrevistador: Não? Nada? Tudo muito bem? 
Entrevistado: É.

Entrevistador: É, hum. E você continua usando o 5DNET como você usava antes?

Entrevistado: Eu só uso para postar recado.

Entrevistador: Só para postar recado? Mas você acha que hoje, por exemplo, você usa, quando você entrou aqui no começo do ano, você acha que você usava mais, menos, igual?

Entrevistado: Menos.

Entrevistador: Agora você acha que você usa menos ou mais?

Entrevistado: Mais por [trecho inaudível]

Entrevistador: É, porque que você acha que usa mais?

Entrevistado: Porque eu não conhecia o 5DNET.

Entrevistador: E aí você foi gostando, que você foi achando assim?

Entrevistado: Gostando.

Entrevistador: Você foi conhecendo, aprendeu a mexer? Já? Você acha que você mexe super bem?

Entrevistado: Claro.

Entrevistador: E se você tivesse que mudar alguma coisa? O que você gostaria de mudar para que ele ficasse ainda mais legal? Você falou que nada é chato, mas se você pudesse mudar alguma coisa para que ele ficasse mais legal, o que você acha que poderia ser assim? Tem alguma ideia, alguma coisa que vem na sua cabeça?

Entrevistado: Não, nada [trecho inaudível].

Entrevistador: Por exemplo, você gosta muito de comentar, né, no 5DNET de outras pessoas, né, você entra facilmente? Você gosta de comentar? Você tem alguma dificuldade? Alguma coisa assim?

Entrevistado: Eu gosto de comentar. Prefiro comentar.

Entrevistador: Você entra sozinho ou precisa de ajuda?

Entrevistado: Eu entro sozinho.

Entrevistador: Você entra sozinho? E acha tudo bem, está gostando de tudo? Alguma sugestão?

Entrevistado: Não.

Entrevistador: Não? Então tá. Tem alguma coisa que você queira dizer do 5DNET?

Entrevistado: Tô gostando.

Entrevistador: Está gostando? Você acha que tem que continuar do jeito que tá.

Entrevistado: Aham.

Entrevistador: Então tá, é isso. Alguma coisa mais que queira acrescentar? 
Entrevistado: Não.

Entrevistador: Não, então tá. Podemos encerrar.

Entrevistado: Podemos.

Nome: HPB - G003234

Unidade - Rio de Janeiro

Entrevistador: Você lembra do 5DNET né, que a gente viu lá? Rapidinho, tá vou fazer só umas perguntinhas, sabe ir respondendo tá, pode ser?

Entrevistado: Uhum.

Entrevistador: Então tá. O que você acha que serve aquele 5DNET que a gente usa?

Entrevistado: Para aprender a [trecho inaudível] com os outros e brincar em conjunto.

Entrevistador: E o que você gosta de ver lá?

Entrevistado: Todas as coisas.

Entrevistador: Tudo, e o que que tem lá que você gosta? O que são todas essas coisas?

Entrevistado:

Entrevistador: E o que você gosta de postar lá?

Entrevistado: O quê?

Entrevistador: O que você gosta de colocar lá, quando você entra no 5DNET?

Entrevistado: É acho que é ver o que as outras pessoas estão fazendo e também imprimir as coisas que imprimir, alguém, é mostrar às outras pessoas que a pessoa fez isso.

Entrevistador: E você lê o que os outros postam lá?

Entrevistado: Uhum.

Entrevistador: Sempre?

Entrevistado: Algumas vezes, quando [trecho inaudível].

Entrevistador: E qual foi a coisa mais legal que você viu ou fez no 5DNET?

Entrevistado: É, jogo [trecho inaudível] né, e os outros jogos também.

Entrevistador: E de mais chato?

Entrevistado: Nenhum.

Entrevistador: E para que que você usa o 5DNET?

Entrevistado: Pá se divertir com os outros, é, conversar e falar sobre oh, qual o nome? Qual o nome da mãe? Fazer, agora eu já tô fazendo [trecho inaudível].

Entrevistador: E o que você gostaria de mudar lá para ficar mais legal?

Entrevistado: Não, eu não mudaria nada não, tá legal. 
Entrevistador: E você usa o 5DNET como você usava quando você começou? Ou você parou de usar um pouco? Como é que está a sua frequência lá?

Entrevistado: Uh, tá ótimo, tá bom, tá normal.

Entrevistador: Você entra sempre que você vem aqui?

Entrevistado: O que?

Entrevistador: Você entra sempre que você vem?

Entrevistado: Aham, eu sempre venho.

Entrevistador: Aí você entra lá no 5DNET?

Entrevistado: Aham, quando eu venho para cá, né?

Nome: FSL - G005642

Unidade: Rio de Janeiro

Entrevistador: Então, a gente estava falando disso aqui fora, não é? Eu vou começar comas perguntas. É... na sua opinião, para que é que serve 5D-NET?

Entrevistado: a 5D-NET serve para cri... criar blogs ou então, pra se... é... pra te fazer novos amigos na 5D-NET tipo de outras 5Ds, de outros Sarah e, serve também pra criar blogs e conversar sobre assuntos assim. Eu falei pra selar amizade, hein! Deram um monte de ficas no meu blog e eu decidi que era bom e... ahn... fiz uma assembleia para decidirmos isso todo mundo junto...

Entrevistador: Ah, bacana! ...

Entrevistado: ... e decidimos que vai ser um show de talento e...

Entrevistador: E você usou o 5D-NET para combinar isso com o pessoal?!

Entrevistado: É.

Entrevistador: E o que você gosta de ver no 5D-NET?

Entrevistado: O que é que eu gosto de vê no 5D-NET?... É, eu não gosto de fazer quase nada no 5D-NET, porque eu gosto mesmo é de brincar.

Entrevistador: Mas não tem nenhuma coisa assim que você goste de ver lá?

Entrevistado: Ah! Tem, é... Não.

Entrevistador: Então tá bom. Mas você gosta de postar? Você gosta de colocar alguma coisa lá?

Entrevistado: É, às vezes, às vezes gosto.

Entrevistador: Tipo o quê?

Entrevistado: Tipo... quando a gente faz atividade, a gente tira foto ou então filma, eu gosto de postar lá "pro“ outros vê”. Aí dá ideia lá, se gostou, se não gostou. 
Entrevistador: E você gosta de ler o que as outras pessoas postam lá?

Entrevistado: Só... só quando... tipo, quando eu já estou na 5D, né? Vendo o que botaram pra mim, eu vejo o que botaram pras outras pessoas e às vezes eu dou ideia "pras outras pessoas". Boto... escrevo um negócio no... na $5 \mathrm{D}$ de outra pessoa.

Entrevistador: Entendi. E assim, qual foi a coisa mais legal que você já viu ou já fez lá na 5D-NET? Uma coisa que você lembre.

Entrevistado: A... coisa legal que eu já fiz lá... Esse negócio de selar amizade, show de talento...

Entrevistador: E assim, e de mais chato que você já fez ou viu.

Entrevistado: É lá... é... que eu já fiz ou vi? ... Não, não me lembro, não.

Entrevistador: Não tem nada chato que você não tenha gostado?

Entrevistado: Não, não.

Entrevistador: E você continuou usando o 5D-NET como você usava antes?

Entrevistado: Não. Agora, eu... tô mais... brincando das brincadeiras que tem labirinto.

Entrevistador: Tem algum motivo pra isso?

Entrevistado: Tem. Porque eu acho que... quanto mais mexer na 5D-NET, menos tempo a gente tem para aproveitar as brincadeiras do labirinto.

Entrevistador: Entendi. E o que você gostaria de mudar na 5D-NET para que ele ficasse mais legal?

Entrevistado: Sei lá! É... botar aplicativo, como o Orkut... botar aplicativo, joguinho, é... é, criar comunidade, pra... poder botar assunto e falar... tipo, a gente já faz isso no blog, mas faz uma comunidade, mas não tem outras coisa...

Entrevistador: Entendi. Tem mais alguma coisa que você queira falar sobre a 5DNET?

Entrevistado: Não... só que a 5D-NET é bom.

Entrevistador: Então está bom. Pode encerrar?

Nome: AFS - G006628

Unidade: Rio de Janeiro

Entrevistador: Então, agora a gente vai responder aquelas perguntinhas que eu tinha falado contido da 5D-NET que a gente tava mexendo tá?

Entrevistado: Tá. 
Entrevistador: Vou te perguntar só algumas coisas, tá bom?

Entrevistado: Tá.

Entrevistador: Você lembra que a gente acabou de mexer lá, que a gente viu o comentário da Cecília?

Entrevistador: Hum, hum.

Entrevistador: Aí, pra você assim... pra que serve o 5D-NET? Aquilo que a gente tava mexendo?

Entrevistado: Pra conversar com os amigos do 5D, do D5-NET.

Entrevistador: Lá no D5-NET? E você faz isso?

Entrevistado: De vez em quando.

Entrevistador: É? O que você gosta de ver lá no 5D-NET?

Entrevistado: Os comentários que as outras pessoas coloca lá.

Entrevistador: Você gosta só de ver isso, só os comentários?

Entrevistador: É, comentários... Sei lá. Ver os comentários, postar foto...

Entrevistador: Mais o quê?

Entrevistado: Escrever mensagem... Escrever mensagem pro senhor Ogã.

Entrevistador: Aí, esse daí não é 5D-NET, o do ogã. O do Ogã a gente faz no labirinto,

Entrevistador: É né?
É.

Entrevistador: E o que você gosta de colocar lá, de postar no 5D-NET?

Entrevistado: Fotos, vídeos.

Entrevistado: É você já fez muito isso?

Entrevistador: Já.

Entrevistador: É?

Entrevistado: Hum, hum.

Entrevistador: Toda tarde você vai lá pro 5D-NET?

Entrevistado: Vou.

Entrevistador: Vai? Você lê o que as outras pessoas postam lá? Você falou que gosta de postar foto, mas você também vê as fotos dos outros?

Entrevistado: Vejo.

Entrevistador: Vê? E qual foi a coisa mais legal que você já viu no 5D-NET?

Entrevistado: É... Aquela minha foto com a Bia jogando de tabuleiro.

Entrevistador: É a coisa mais legal?

Entrevistado: De peteleco. Eu acho aquilo legal. 
Entrevistador: Mas aquilo é uma foto sua. Mas uma coisa que um amigo, que um amigo postou, que alguém postou, o que você acha de mais legal que você viu lá?

Entrevistado: As mensagens que eles mandam pra mim.

Entrevistador: Só isso?

Entrevistado: E.

Entrevistador: É de mais chato, o que você viu lá que achou mais chato assim?

Entrevistado: Nada.

Entrevistador: Nada? Você gosta de tudo que você vê lá?

Entrevistado: Hum, hum.

Entrevistador: E você... sim, se você pensar assim, você continua usando o 5D-NET como você usava antes?

Entrevistado: Sim.

Entrevistador: É?

Entrevistado: Hum, hum.

Entrevistador: Você lembra que a gente abriu lá agora e tinha um tempão que você não postava alguma coisa lá, né?

Entrevistado: Hum, hum.

Entrevistador: O que você acha?

Entrevistado: Eu acho legal entrar no 5D-NET, ver os desafios.

Entrevistador: Mas os desafios são no labirinto, a gente tá falando daquela partezinha que a gente tá mexendo agora, que você respondeu o comentário da Fernanda. Você tem usado bastante aquela partezinha ali?

Entrevistado: Tenho.

Entrevistado: Tem? O que você gostaria de mudar no 5D-NET pra ele ficar mais legal?

Entrevistado: As brincadeiras.

Entrevistador: No 5D-NET, naquele blog, na parte onde a gente posta foto, ali?

Entrevistado: Não. O que eu acho... não sei.

Entrevistador: Lá no 5D-NET, onde você posta foto e você comenta nas coisa dos amigos, lá você gostaria de mudar alguma coisa pra ali ficar mais legal?

Entrevistado: Hum, hum.

Entrevistador: O quê?

Entrevistado: Deixa eu pensar. As brincadeiras.

Entrevistador: Como assim as brincadeiras? 
Entrevistado: Tipo... como é que... o "jabolo", o jabolo é um jogo difícil, aí você tem que tentar fazer... hum, tentar fazendo assim, aí depois, quando tu pega o jeito de fazer rápido você se embola.

Entrevistador: Então, essa parte que você tá falando é do labirinto, o que eu tô falando aquela parte do 5D-NET, do ladinho onde a gente posta foto, onde a gente faz aquele login, igual ao que a gente fez agora. Ali você gostaria de mudar alguma coisa?

Entrevistado: Não.

Entrevistador: Não? Acho que é isso, né?

Nome: MS - G007016

Unidade: Rio de Janeiro

Entrevistador: Na sua opinião, pra que serve o 5D-NET?

Entrevistado: O 5D-NET? A gente entra e escolhe o que a gente pode brincar de jogo.

Entrevistador: Mas isso que você tá falando é o Labirinto. O 5D-NET é aquela parte que a gente te mostrou, a parte do cantinho.

Entrevistado: A gente entra e vê o que a pessoa escreveu. Por exemplo, a pessoa escreveu pra

mim, aí eu entro lá e eu vejo.

Entrevistador: O que você gosta de ver no 5D-NET?

Entrevistado: As perguntas que fazem pra mim, aí eu faço.

Entrevistador: Só isso ou você gosta de mais alguma coisa?

Entrevistado: Ah, só.

Entrevistador: O que você gosta de colocar ou postar no 5D-NET?

Entrevistado: As mensagens. Aí eu faço uma pergunta no 5D-NET e as pessoas perguntam para mim.

Entrevistador: Mas tem que ser sobre algum assunto específico ou não quando você põe mensagem ou foto?

Entrevistado: Não sei.

Entrevistador: Qual foi a coisa mais legal que você viu ou fez no 5D-NET?

Entrevistado: Não sei.

Entrevistador: Não tem nada que você achou legal, alguma coisa que você fez?

Entrevistado: A Chaiane e a Rafaela escreveram no 5D-NEG que a Camile é legal...

Entrevistador: É de mais chato?

Entrevistado: Mais chato? 
Entrevistador: Não tem nada, assim, que você não gosta ou ache chato? Sei lá.

Entrevistado: Não.

Entrevistador: Nada que você... nada? Tudo você gosta? Você gosta de tudo que tem lá?

É? Você continua usando o 5-NET como antes? Quando começou o projeto,

ano passado e agora, você continua usando da mesma maneira ou usa menos ou mais?

Entrevistado: Menos.

Entrevistador: Por quê?

Entrevistado: Ah, às vezes é chato, às vezes não.

Entrevistador: Mas você disse que não tinha nada chato quando eu te perguntei antes.

Entrevistado: A Internet é, os jogos não.

Entrevistador: Mas o D5-NET... os jogos é aquela outra parte, o Labirinto, o 5D-NET é

aquela outra parte. Ai eu tô perguntando só daquela outra parte, se você usa menos ou mais.

Entrevistado: Um pouco.

Entrevistador: Um pouco o quê? Mais ou menos?

Entrevistado: Às vezes eu não uso o 5D-NET.

Entrevistador: Então, por quê?

Entrevistado: Por quê? Não sei.

Entrevistador: O que você gosta de mudar no 5D-NET pra que ele fique mais legal?

Entrevistado: Os jogos.

Entrevistador: Mas aí você tá falando do Labirinto. O 5D-NET é aquela outra parte onde

você põe seu nome, daí você põe a senha, vê outras pessoas de outros lugares, da 5D de Brasília, de São Luís. Esse negócio da Camila que você

falou foi do 5D-NET.

Entrevistado: Então.

Entrevistador: Então, mas agora você tá falando dos jogos é do Labirinto. Entendeu ou não? Então, o que você gostaria de mudar no 5D-NET pra que ele fique mais legal? O que tá faltando pra deixar ele mais legal? Você já acha ele legal assim, você não acha que ele tá legal?

Entrevistado: Eu acho muito legal [trecho inaudível]. Os outros eu não sei, os outros acham legal ou rui; por mim, eu acho legal.

Entrevistador: Você lê o que os outros postam no 5D-NET? 
Entrevistado: Hum, hum.

Entrevistador: Você gosta... Você gosta de ficar olhando ou entra mais pra postar suas fotos?

Entrevistado: Eu entro pra postar minhas fotos, aí depois eu olho as perguntas que as Pessoas sempre faz, aí eu vejo.

Entrevistador: Você entra no 5D-NET da outra pessoa só pra ver o que ela colocou ou Você só olha se for pra ver as perguntas da sua foto?

Entrevistado: Então, tá. 
Nome: NFG - G015095

Unidade: Rio de Janeiro

Entrevistador: Então, Nilson, a gente vai te perguntar umas coisas, porque a gente quer saber um pouquinho sobre o que você acha do 5D-NET, tá?

Entrevistado: Tá! ...

Entrevistador: Para que você acha que serve o 5D-NET?

Entrevistado: Para quê?

Entrevistador: Eh!

Entrevistado: Para me ajudar na memória...

Entrevistador: Oi? ...

Entrevistado: Para me ajudar na memória...

Entrevistador: Bacana! Mais como é que você usa o 5D-NET para te ajudar assim... para te ajudar na memória?...

Entrevistador: Fazer atividades para poder lembrar mais coisas que eu não consigo de jeito nenhum...

Entrevistador: E o que você gosta de ver no 5D-NET? Além de vocês?...(risos) Ah!

Entrevistado: Meus amigos e os profissionais... Alguns são legais...

Entrevistador: Bacana! Mas lá no 5D-NET você falou que gosta de ver a gente... Você vê a gente como... lá?...

Entrevistado: Amigas...

Entrevistador: Então... mas o que a gente bota lá pra você ver?...

Entrevistado: (silêncio)

Entrevistador: O que a gente estava vendo hoje? ... Agora... O que a gente botou numa página que dava pra ver de todo mundo?

Entrevistado: Perfil.

Entrevistador: Também!... Boa! O que você gosta de colocar no 5D-NET?

Entrevistado: As minhas experiências... O que eu estou melhorando... O quanto eu já melhorei...

Entrevistador: Bacana! Quando a gente faz alguma coisa, tipo um jogo, ou quando a gente vai lá para a casa de atividades de vida diária e faz alguma coisa, a gente sempre tira fotos ou a gente faz um vídeo ou faz alguma coisa... Você gosta de colocar lá também?...

Entrevistado: Sim. Ver vocês e o grupo inteiro aqui do Sarah, vocês todos tão me ajudando, eu 
eu consigo agora lembrar tudo da matéria que eu estudei no colégio...

Entrevistador: Bacana! Mas quando você entra no 5D-NET, você... éh... O que você lê do que as pessoas postam no 5D-NET?... Se você gosta de ver o que as outras pessoas botam, igual a gente fez hoje...

Entrevistado: No site, aqui no Sarah? ...

Entrevistador: É... Igual a gente estava sentados hoje lá no computador... Lembra?

Entrevistado: Eu uma vez li uma de vocês duas que passaram o dia inteiro comigo e gostaram... Pra mim foi interessantíssimo!...

Entrevistador: Igual hoje... Foi hoje que a gente estava vendo a foto de quando a gente jogou handebol... Lembra? Aí eu botei isso que tinha gostado de ter passado o dia com você.

Entrevistado: Legal!

Entrevistador: E qual foi a coisa mais legal que você viu ou que você fez no 5D-NET?

Entrevistado: Fiz amigos novos, como vocês. Com os garotos, encontrei novas amizades que mudaram a minha vida de certo jeito...

Entrevistador: Legal! ...

Entrevistador: E o que você não gostou, o que você achou chato... Lá no 5D-NET?

Entrevistado: Praticamente nada...

Entrevistador: Bacana! E você continua usando o 5D-NET como antes?

Entrevistador: Como assim como antes?

Entrevistador: Assim... Quando você começou a usar? Você ainda tá usando da forma que você começou, ou você diminuiu o uso ou aumentou o uso?... Como é que está sendo?

Entrevistado: Eu, no começo, achei que era uma coisa comum, "tosca", mas agora pra mim está sendo legal...

Entrevistador: Está sendo legal?

Entrevistado: Tá!...

Entrevistador: Entendi... Então, você está usando mais do que quando começou ou menos?

Entrevistado: Mais...

Entrevistador: Ah! Bacana! E se você pudesse mudar alguma coisa, para ficar mais legal no 5D-NET, o que você mudaria?... Nada? ... Pode viajar, pensar em qualquer coisa para mudar...O que, por exemplo... O que você acha legou num site da Internet que você acha que de repente pudesse ter no 5D-NET? ...

Entrevistado: Nada!...

Entrevistador: Nada? ... Tem certeza?... Então, o 5D-NET é superlegal para você?

Entrevistado: É! 
Entrevistador: Então, não mudaria nada? ... Tá bom, então...

Entrevistado: Tá! ...

Entrevistador: Muito bem, é isso aí... Foi?

Nome: PHGO - G016247

Unidade: Rio de Janeiro

Entrevistador: Você lembra o que é 5DNET?

Entrevistado: [trecho inaudível]

Entrevistador: Não?

Entrevistado: [trecho inaudível] sei [trecho inaudível].

Entrevistador: Não sabe?

Entrevistado: Sei.

Entrevistador: O que você sabe?

Entrevistado: [trecho inaudível]

Entrevistador: 5DNET

Entrevistador: Não é aquele que a gente entra na internet para falar com o pessoal de Brasília, de São Luís... lembrou?

Entrevistado: [trecho inaudível]

Entrevistador: E para que você acha que ele serve?

Entrevistado: Pra gente falar com eles...

Entrevistador: Falar com quem?

Entrevistado: Com eles.

Entrevistador: Só para isso? É?

Entrevistado: [trecho inaudível]

Entrevistador: O que você gosta de ver no 5DNET?

Entrevistado: Ver ou fazer?

Entrevistador: É... Ver ou fazer...

Entrevistado: Futebol, doce, pipoca.

Entrevistador: Doce.... e o pessoal bota isso? Você bota? Você posta as fotos dos doces, as receitas....

Entrevistado: Eu já tirei uma foto...

Entrevistador: Você gosta de postar foto? Ou só de ver o pessoal botando?

Entrevistado: Eu já tirei uma foto [trecho inaudível] e botei ali no computador [trecho inaudível]. 
Entrevistador: Aí você colocou no 5DNET? .... Para o pessoal ver lá de Brasília?

Entrevistado: [trecho inaudível]

Entrevistador: Não botou não?

Entrevistado: Para quê?

Entrevistador: Você não falou que é para o pessoal ver?

Entrevistado: [trecho inaudível]

Entrevistador: E o que você gosta de colocar no 5DNET?

Entrevistado: Futebol.

Entrevistador: Aí você bota as coisas de futebol? Ou você deixa para lá, só gosta de jogar?

Entrevistado: Gosto de jogar futebol.

Entrevistador: Você gosta de postar as fotos de você jogando futebol também?

Entrevistado: [trecho inaudível]

Entrevistador: Não gosta? Quando você entra lá no 5DNET, o que você coloca? Você lê o que as outras criança colocam? Naquele quadrinho que fica do lado?

Entrevistado: Que quadrinho?

Entrevistador: ... que tem as fotos...

Entrevistado: Que quadrinho?

Entrevistador: A gente entra no labirinto... aí do ladinho tem as fotos das pessoas... né? Você costuma ler?

Entrevistado: Nunca li.

Entrevistador: Você lembra qual a coisa mais legal que você já viu no 5D?

Entrevistado: Não.

Entrevistador: Não lembra o que foi alguma coisa que alguém botou, alguma foto, alguma receita... não lembra qual foi a coisa mais legal que você já viu? Não?

Entrevistado: Sei...

Entrevistador: O que?

Entrevistado: Que eu fiz, naquela hora que a gente pintou aquela boneca... eu pintei com cor de vermelho, mas não é a melhor coisa que eu fiz...

Entrevistador: ... não, mas no 5DNET? Você colocou a foto da Monalisa na 5DNET?

Entrevistado: [trecho inaudível]

Entrevistador: Não? Ah, entendi... 
Entrevistador: E teve alguma coisa chata que você não gostou?.... Lá no 5DNET? Que você viu algum amigo botando?

Entrevistado: .... que?

Entrevistador: No 5DNET... as fotos, as receitas que o pessoal bota... teve alguma

Entrevistado: Não. coisa que você viu que foi chata?

Entrevistador: Não?

Entrevistado: .... Tem!

Entrevistador: Qual?

Entrevistado: A foto do Henrique...

Entrevistador: O que tinha a foto do Henrique?

Entrevistado: Não sei...

Entrevistador: Ué... era chato e você nem lembra o que era?

Entrevistado: [trecho inaudível].

Entrevistador: Então tá bom...

Entrevistador: E... você está usando o 5DNET como antes?

Entrevistado: Tô.

Entrevistador: Você entra ou não entra?

Entrevistado: Entro.

Entrevistador: Entra? Entrevistador: Todo dia ou não?

Entrevistado: todo dia.

Entrevistador: É? Você entra no labirinto ou você entra no 5DNET todo dia?

Entrevistado:... No labirinto.

Entrevistador: Ah.... no 5DNET não... para ver o que as pessoas fizeram?

Entrevistado: [trecho inaudível].

Entrevistador: Entendi....

Entrevistador: E tem alguma coisa que você gostaria de mudar... para ficar mais legal....

Entrevistado: [trecho inaudível].

Entrevistador: O quê?

Entrevistado: Tirar tudo.... só deixar futebol.

Entrevistador: Tirar tudo e só deixar o futebol? .... e se no 5DNET tiver foto de futebol? Você disse que você quase não entra? De repente tem lá e você nem viu! Né?

Entrevistado: Não tem! 
Entrevistador: ... Não sabe?

Entrevistado: Não tem!

Entrevistador: Então não tem? Tá bom! Ia ficar mais legal então se tirasse tudo e só deixasse o futebol?

Entrevistado: [trecho inaudível].

Entrevistador: É?.... tá bom!

Nome: GGPS - G016998

Unidade: Rio de Janeiro

Entrevistador: Então, Gu, na sua opinião, para que serve o 5DNET? Assim, o que você faz lá? Você coloca fotos, encontra outras pessoas, isso? O que você gosta de ver no 5DNET?

Entrevistado: Acho que [trecho inaudível]

Entrevistador: Não, o 5DNET, aquele que eu te mostrei ainda agora, que você colocou lá o seu login, a sua senha. O que você gosta de colocar no 5DNET? Que a gente viu aquela hora...

Entrevistado: Fotos.

Entrevistador: Você leu o que os outros postam no 5DNET? O que os seus amigos colocam lá, você comenta nas fotos?

Entrevistado: Aham.

Entrevistador: Sim, e qual foi a coisa mais legal que você viu ou fez no 5DNET?

Entrevistado: Jogo da peça.

Entrevistador: Não, Gustavo, naquele 5DNET, lembra? Que tem as suas fotos, você lembra? Que tem vários amigos, que você entra lá e vê as fotos. Que coisa mais legal você já fez lá?

Entrevistado: Eu não sei.

Entrevistador: E de mais chato? Também não sabe?

Entrevistado: Nada.

Entrevistador: Você continua usando o 5DNET como antes? Fala só um pouquinho alto.

Entrevistado: Sim.

Entrevistador: O que você gostaria de mudar no 5DNET para que ele fique mais legal? Entrevistado: Não sei.

Entrevistador: Só isso. 
Nome: GKVC - N128942

Unidade: São Luis

Entrevistador: Então, Gleildson, na sua opinião, para que serve o blog?

Entrevistado: Para colocar foto.

Entrevistador: O que você quer ver no blog?

Entrevistado: Nada.

Entrevistador: Você não ver nada no blog quando você entra? Você não olha nada lá?

Entrevistado: Não sei não.

Entrevistador: Você entra na sua página ou na página de outras pessoas?

Entrevistado: Na minha e na dos outros.

Entrevistador: O que você gosta de ver na página dos outros?

Entrevistado: Ver fotos.

Entrevistador: O que você gosta de colocar no blog?

Entrevistado: Nada.

Entrevistador: O que você pode colocar aí?

Entrevistado: Foto.

Entrevistador: Você gosta de colocar fotos do que?

Entrevistado: Das pessoas.

Entrevistador: É você quem faz as fotos?

Entrevistado: É.

Entrevistador: Como são essas fotos?

Entrevistado: Eu e outros colegas.

Entrevistador: Qual foi a foto mais legal que você viu ou fez no blog?

Entrevistado: Fotos.

Entrevistador: Mas qual foi a foto mais legal, o que você mais gostou de fazer lá no blog?

Entrevistado: A minha foto com meus colegas.

Entrevistador: Tem uma foto sua com seus colegas no seu blog? De quando?

Entrevistado: Tem. De hoje.

Entrevistador: Você acha que tem alguma coisa chata no blog?

Entrevistado: Não, nada.

Entrevistador: Você continua usando o blog como antes?

Entrevistado: É. 
Entrevistador: Quantas vezes você usa o blog?

Entrevistado: De vez em quando.

Entrevistador: Por que você não usa todas as tardes?

Entrevistado: Não sei.

Entrevistador: O que você gostaria que mudasse no blog? Alguma coisa que ficasse diferente, para ficar mais bonito, melhor?

Entrevistado: Não sei.

Entrevistador: Você acha que o blog é legal assim? Ou tem alguma ideia?

Entrevistado: Tenho uma ideia.

Entrevistador: Qual a ideia que você acha que pode ficar mais bonito?

Entrevistado: Um negócio, não sei não.

Entrevistador: Você lê o que os outros colocam no blog? Os comentários deles?

Entrevistado: Não sei ler direito.

Entrevistador: Mas alguém lê para você?

Entrevistado: Lê.

Entrevistador: Quem?

Entrevistado: Meus colegas.

Nome: ESM - N132005

Unidade: São Luis

Entrevistador: Manu, com que frequência e em que situações você usa o blog?

Entrevistado: Porque tem muitas coisas divertidas.

Entrevistador: Qual a função dessa ferramenta aqui no 5D?

Entrevistado: Porque conheço outros adolescentes, que podem me tirar de um mundo e botar para um mundo que seja mais interessante.

Entrevistador: Quais são os pontos positivos e negativos no blog?

Entrevistado: É legal, eu olho as fotos das outras pessoas, eu mando, eles mandam.

Entrevistador: Tem alguma coisa que você não goste no blog, alguma coisa negativa?

Entrevistado: Não.

Entrevistador: Tu tem alguma sugestão para tornar o blog melhor?

Entrevistado: Não.

Entrevistador: Não tem nenhuma dica?

Entrevistado: Não. 
Entrevistador: Ele está bom desse jeito?

Entrevistado: Tá.

Entrevistador: Você lê o que as outras crianças e os outros estudantes das outras 5D postam?

Entrevistado: Li.

Entrevistador: O que você acha disso?

Entrevistado: Acho que a gente também pode mandar.

Entrevistador: Você gosta do que eles postam:

Entrevistado: Gosto.

Entrevistador: Com que frequência você usa o blog? Quantas vezes tu costuma usar o blog?

Entrevistado: Todo dia. Toda quarta e sexta eu vou postar alguma coisa.

Entrevistador: Você vai postar alguma coisa hoje?

Entrevistado: Vou.

Nome: CLFSS - N132652

Unidade: São Luis

Entrevistador: Na sua opinião, para que serve o blog? Aquele blog ali no computador, olha... para que você acha que ele serve?

Entrevistado: Para mandar email e para ver fotos.

Entrevistador: O que você gosta de ver no blog?

Entrevistado: Fotos.

Entrevistador: Tem mais alguma coisa que é legal de ver no blog?

Entrevistado: Não.

Entrevistador: O que você gosta de colocar ou postar no blog? O que você posta?

Entrevistado: Nada.

Entrevistador: Nunca postou nada? Nem foto?

Entrevistado: Não.

Entrevistador: Qual foi a coisa mais legal que você viu ou fez no blog?

Entrevistado: As fotos quando tirei lá na casa de vovó e as fotos que tava eu e meu primo.

Entrevistador: Tem essas fotos lá no seu blog?

Entrevistado: É. 
Entrevistador: E o que tem de mais chato?

Entrevistado: Não sei.

Entrevistador: Tem alguma coisa que você acha chato ou não gosta no blog?

Entrevistado: Não sei.

Entrevistador: Você continua usando o blog como antes?

Entrevistado: Não.

Entrevistador: Você acha que usava mais o blog?

Entrevistado: Não.

Entrevistador: Tá do mesmo jeito?

Entrevistado: Tá.

Entrevistador: Você usa muito ou pouco?

Entrevistado: Pouco.

Entrevistador: Você queria usar mais?

Entrevistado: Queria.

Entrevistador: O que você gostaria de mudar no blog, para deixar ele mais legal? Mais bonito?

Entrevistado: Eu queria botar para gente postar vídeos e músicas.

Entrevistador: Lá não pode postar vídeo e música?

Entrevistado: Música não sei.

Entrevistador: Tem alguma coisa que faria o blog ficar mais legal?

Entrevistado: Não.

Entrevistador: Você o que outros postam no blog?

Entrevistado: Não.

Entrevistador: Você não entra assim para ver o que o Gleildson botou, a Manutenção.... para ver o que tem lá?

Entrevistado: Não.

Entrevistador: Só na sua página?

Entrevistado: É.

Nome: NSN - D157989

Unidade: BSB - LN

Entrevistadora: Nathália, você está com quantos anos hoje?

Entrevistada: 12 anos. 
Entrevistadora: Quando você faz aniversário?

Entrevistada: 15 de maio.

Entrevistadora: Quando você começou no projeto $5^{\mathrm{a}}$ dimensão, você estava fazendo qual série?

Entrevistada: Acho que era a $2^{\mathrm{a}}$. Não, acho que foi a $3^{\mathrm{a}}$.

Entrevistadora: Você estudava em qual escola naquela época?

Entrevistada: No CEMA.

Entrevistadora: O que foi que aconteceu naquela época?

Entrevistada: Eu sofri um acidente de carro.

Entrevistadora: E você veio se tratar aqui no Sarah, com a sua mãe, foi isso?

Entrevistada: Foi.

Entrevistadora: Depois de um tempo, Nathália, você entrou no Projeto $5^{\mathrm{a}}$ Dimensão, tinha vários amigos lá, quais os nomes deles?

Entrevistada: É, eu não lembro muito bem: o Rodrigo, Lucas, Talisson, como é que é nome....

Entrevistadora: Thiago.

Entrevistada: Carol.

Entrevistadora: Hum, Carol era sua colega da $5^{\mathrm{a}} \mathrm{D}$ ?

Entrevistada: Era.

Entrevistadora: Professora?

Entrevistada: hum-hum.

Entrevistadora: ah, professora! Tá bom. Como você era na escola quando você entrou no projeto $5^{\mathrm{a}}$ Dimensão?

Entrevistada: Ah, eu ia bem.

Entrevistadora: Conta pra gente, tinha colegas lá?

Entrevistada: Tinha.

Entrevistadora: Na hora do recreio você fazia o que?

Entrevistada: ah eu brincava de tudo.

Entrevistadora: Qual a brincadeira que você mais, vamos lá?

Entrevistada: Brincava de tudo.

Entrevistadora: O que tinha lá?

Entrevistada: Futebol.

Entrevistadora: Futebol.

Entrevistada: Queimada, espirobol. 
Entrevistadora: Espirobol? Lá no CEMA tinha isso?

Entrevistada: Tinha. Vôlei e outras coisas.

Entrevistadora: Você tirava boas notas, você lembra como era?

Entrevistada: Sim.

????? (Mãe? Entrevistadora???): Sim, tirava boas notas.

Entrevistadora: E a professora mandava bilhetinhos para sua mãe, falando de que?

Entrevistada: Ah, às vezes, que eu tava conversando muito.

Entrevistadora: Ah! Você lembrou? É mesmo, conversava muito. Mas a professora, era só essa queixa ou ela se queixava de mais alguma coisa?

Entrevistada: Não, às vezes ele me elogiava.

?????? (Mãe? Entrevistadora??): Eu me lembro disso também, ela elogiava.

Entrevistadora: Elogiava quando? O que você fazia que merecia elogio?

Entrevistada: Quando eu não conversava, quando tiravas notas boas.

Entrevistadora: E a sua professora comentou, por exemplo, numa visita que a fonoaudióloga fez na sua escola e a psicóloga Juliana, a professora comentou que você era boa amiga de seus colegas, como era isso?

Entrevistada: É que eu ............... amigas, né? Mas amigo é legal porque você pode dividir as coisas.

Entrevistadora: Ela falou que você conversava, mas era uma conversa igual outras crianças, não era exagerado. Você lembra em qual momento você conversava mais?

Entrevistada: Não.

Entrevistadora: Não? Era no meio da aula?

Entrevistada: Às vezes sim.

Entrevistadora: Ou era mais quando você acabava a sua tarefa?

Entrevistada: Quando eu acaba a tarefa e, às vezes, no meio da aula.

Entrevistadora: É, a professora contou isso mesmo, que você conversava, mas era uma conversa como de outras crianças, não era exagerada não e que normalmente acontecia quando você já tinha acabado suas tarefas. Você acha que você era rápida para fazer as tarefas?

Entrevistada: Eu acho.

Entrevistadora: Mas ela conta também que você era boa amiga porque você ajudava as colegas a fazer os trabalhos.

Entrevistada: Era assim, às vezes eu pedia ajuda para elas e, às vezes, elas me pediam ajuda.

Entrevistadora: Qual era matéria que você sabia ensinar?

Entrevistada: Matemática, as minhas matérias preferidas é matemática e geografia. 
Entrevistadora: Matemática e geografia? Excelente! Quando você entrou aqui no Projeto $5^{\circ}$ Dimensão, o que você achou do projeto?

Entrevistada: Achei muito legal né? Porque tem muitas brincadeiras que ensina.

Entrevistadora: Além das brincadeiras que são legais, por que é legal também? Vamos lá.. Tinha as brincadeiras legais.

Entrevistada: Ensina né?

Entrevistadora: Ah é? Ensina o que? Vamos tentar lembrar, o que você aprendeu no Projeto $5^{\mathrm{a}}$ Dimensão?

Entrevistada: Ah, a ter mais respeito com as pessoas.

Entrevistadora: Olha que lindo, a ter mais respeito?

Entrevistada: A ajudar.

Entrevistadora: A ajudar?

Entrevistada: É

Entrevistadora: E você não tinha muito respeito com as pessoas não?

Entrevistada: Tinha (risos).

Entrevistadora: Mas aí você mudou?

Entrevistada: Mudei.

Entrevistadora: Ficou mais respeitosa?

Entrevistada: É porque cada vez é diferente né?

Entrevistadora: Cada pessoa, né? É diferente. Então você aprendeu novas brincadeiras, aprendeu a respeitar mais as pessoas, o que mais?

Entrevistada: Eu não lembro muito bem.

Entrevistadora: Dos jogos que você conheceu no Projeto $5^{\mathrm{a}}$ Dimensão, qual que você achou bem bacana?

Entrevistada: Foi o passeio na lagoa que a gente fez, era o dia das crianças, era como um quebra cabeça, a gente tinha que sair no barco e ir achando as letras.

Entrevistadora: As peças?

Entrevistada: É, as peças, e depois quem chegasse primeiro ia ganhar prêmio.

Entrevistadora: Ah que bacana, essa atividade deve ter sido muito legal mesmo. No Projeto $5^{\text {a }}$ Dimensão vocês podiam fazer passeios todos os dias?

Entrevistada: Sim.

Entrevistadora: Todo dia tinha passeios?

Entrevistada: Não, às vezes.

Entrevistadora: Ah, às vezes. Você fazia atividades dentro da sala?

Entrevistada: É. 
Entrevistadora: Quais atividades?

Entrevistada: Jogar Playstation, mexer no computador.

Entrevistadora: Qual era o seu preferido?

Entrevistada: Jogar Playstation.

Entrevistadora: Quantos Playstation tinha?

Entrevistada: um.

Entrevistadora: Não dava briga não?

Entrevistada: Não.

Entrevistadora: Como que era organizado o uso do Playstation lá?

Entrevistada: Assim, a gente gostava mais de jogar Guitar Hero, então quem ganhava jogava com o próximo.

Entrevistadora: Você acha que essa organização funciona bem?

Entrevistada: Funcionou né? Pra gente.

Entrevistadora: A sua mãe contava, por exemplo, que depois que você conheceu o Projeto $5^{\mathrm{a}} \mathrm{D}$, você passou a ser mais organizada e a organizar as atividades de grupo. Ela percebeu que você era assim uma líder do grupo. Você concorda?

Entrevistada: (risos) eu concordo.

Entrevistadora: Você aprendeu a ser assim aqui no Projeto $5^{\text {a }}$ Dimensão?

Entrevistada: Hum-hum.

Entrevistadora: Como será que isso aconteceu?

Entrevistada: Ai, eu não sei.

Entrevistadora: Ela achou, por exemplo, que você começou a ser mais criativa, passou a ser mais organizada e passou a ajudar os outros também, você lembra disso?

Entrevistada: Não muito.

Entrevistadora: Ok. Antes, segundo a sua mãe contava, você tinha dificuldades de obedecer às regras, alguém reclamava disso?

Entrevistada: Sim.

Entrevistadora: Quem?

Entrevistada: As professoras.

Entrevistadora: Quem mais, só as professoras?

Entrevistada: Não sei. Eu não lembro.

Entrevistadora: Agente viu na visita escolar que a professora achava que às vezes você tinha dificuldade de seguir as regras, mas era com as outras crianças.

Entrevistada: É, é porque as vezes que queria fazer uma coisa só que tinha que fazer outra. 
Entrevistadora: E você aprendeu a seguir as regras onde?

Entrevistada: é porque elas faziam com que eu fizesse o que elas estavam pedindo, né?

Entrevistadora: E isso para você foi difícil, seguir as regras?

Entrevistadora: Ah, não muito.

Entrevistadora: Natália, houve um tempo que você foi acompanhada por uma psicopedagoga, com é que começou este acompanhamento?

Entrevistada: Ela me chamou, a gente foi lá pra baixo, ela foi me perguntando as coisas sobre a escola, me foi dando exercícios e eu fui fazendo.

Entrevistadora: E esses exercícios te ajudaram em alguma coisa?

Entrevistada: Sim.

Entrevistadora: Você, nas tarefas de casa, trocava letras.

Entrevistada: Trocava, mas agora não troco mais não,

Entrevistadora: Não troca mais?

Entrevistada: Só um pouquinho.

Entrevistadora: Uma vez ou outra?

Entrevistada: Só que a minha mãe fica falando o tempo todo que eu não gosto de colocar acento, eu não estou colocando acento nas palavras.

Entrevistadora: Hoje você ainda não coloca acento nas palavras?

Entrevistada: Não.

Entrevistadora: Algumas.

Entrevistada: Eu coloco, mais assim, tem hora que eu vou escrevendo rápido, esqueço e deixo de colocar acento.

Entrevistadora: Às vezes quando você faz outras coisas assim muito rápido, fica alguma coisa mal feita?

Entrevistada: Sim.

Entrevistadora: Quais coisas você faz rápido? Alguma tarefa de casa?

Entrevistada: Sim, já fiz prova também rápido.

Entrevistadora: Foi? E deixou coisa sem fazer.

Entrevistada: Não.

Entrevistadora: Ou mal feita?

Entrevistada: Não.

Entrevistadora: Você disse que antes você só queria ser a líder.

Entrevistada: É. 
Entrevistadora: Com é que aconteceu depois que você entrou na $5^{\circ} \mathrm{D}$ ?

Entrevistada: Eu aprendi a não fazer mais isso, a trabalhar em grupo.

Entrevistadora: Ah, a trabalhar em grupo? Foi difícil para você deixar os outros serem líderes?

Entrevistada: Um pouquinho.

Entrevistadora: Mas depois?

Entrevistada: Mas depois eu fui me adaptando.

Entrevistadora: Nathália, hoje, quando você pensa sobre o projeto $5^{\text {a }}$ Dimensão, e a gente reflete sobre algumas coisas diferentes, você acha que tem coisas diferentes hoje na sua vida?

Entrevistada: Sim.

Entrevistadora: Algumas coisas você aprendeu onde?

Entrevistada: Aqui né, muitas coisa aqui.

Entrevistadora: Você pode dizer alguma coisa muito importante que você aprendeu aqui no Projeto $5^{\text {a }}$ Dimensão?

Entrevistada: A respeitar as diferenças de cada um.

Entrevistadora: Isso é muito importante. Houve um tempo, Nathália, que você estava estudando em duas escolas, fazendo a primeira série no CEMA e numa escola pública, como foi essa época para você?

Entrevistada: Ah, foi muito ruim, assim, fazer o dever de casa à noite, né?

Entrevistadora: E onde você fazia esse dever de casa?

Entrevistada: Lá na sala, lá na minha casa.

Entrevistadora: Houve um tempo que você fazia dever de casa no trabalho da sua mãe.

Entrevistada: É, foi quando ela tinha que trabalhar um pouquinho até mais tarde e eu não tinha estudado direito, ela aproveita e ficava até meia-noite, fazendo o dever e estudando comigo.

Entrevistadora: E a gente orientou, na época, a Carolina, a psicóloga Juliana também, na época, orientou que vocês tivessem um horário melhor para estudar e também um lugar melhor. Vocês conseguiram fazer isso?

Entrevistada: Sim.

Entrevistadora: E mudou o seu rendimento na escola?

Entrevistada: Mudou.

Entrevistadora: Ficou menos cansativo?

Entrevistada: Ficou, porque antes eu dormia pouco, né?

???: É verdade, dormia pouco e ficava cansada. 
Entrevistadora: Nessa época também, a sua mãe observava que quando você errava uma tarefa, você ficava muito irritada.

Entrevistada: Ficava, porque assim, eu ouvia da professora e a minha mãe explicava de outro jeito e eu ficava brigando com ela dizendo que era daquele jeito que eu tinha aprendido, que ela queria mudar, mas as vezes eu tava certa e as vezes ela tava certa.

Entrevistadora: Ah variava. Será por que, nessa época, lá do segundo ano, sua mãe tava achando que você tava um pouco acomodada, um pouco lenta para fazer as tarefas?

Entrevistada: Era muito cansativo, né?

Entrevistadora: Eu imagino que era isso mesmo, duas escolas, né? Como você gosta muito de esportes, hoje você está como?

Entrevistada: Quando eu ficava com minha mãe, ficava aqui no Sarah, fazia natação, futebol, vôlei. Só que agora, eu tinha acabado de sair da natação, a minha mãe não me colocou ainda não, mas ela quer me colocar no futebol.

Entrevistadora: Você sente falta dos esportes?

Entrevistada: Muita.

Entrevistadora: Hoje quando você estuda para as provas você consegue lembrar de tudo?

Entrevistada: Consigo.

Entrevistadora: Você acha que tem diferença da sua memória hoje?

Entrevistada: Tem.

Entrevistadora: Ok, Nathália, muito obrigada. Você gostaria de dizer mais alguma coisa sobre o projeto?

Entrevistada: Não.

Entrevistadora: Muito obrigada.

Nome: TA

Unidade: BSB - LN

Entrevistadora: Thiago, nós conhecemos você aos sete anos de idade, você estava com sete anos, e você começou a participar do projeto $5^{\text {a }}$ Dimensão em 2007. Naquela época você estudava e a professora se queixava que você tinha certa desorganização no material escolar, não era "coisa" muito organizada não. Você lembra disso?

Entrevistado: não.

Entrevistadora: então. Aí você começou a participar da $5^{\mathrm{a}}$ Dimensão e você lembra desta época?

Entrevistado: Lembro.

Entrevistadora: lembra como era a sala naquela época? 
Entrevistado: não.

Entrevistadora: tinha diversão?

Entrevistado: tinha.

Entrevistadora: quais?

Entrevistado: muitas né, eu não lembro.

Entrevistadora: jogo de mesa?

Entrevistado: tinha.

Entrevistadora: na quadra?

Entrevistado: tinha.

Entrevistadora: o que mais?

Entrevistado: tinha computador, um montão de coisas, tinha jogos, tinha o Playstation...

Entrevistadora: dos jogos que você jogou na $5^{\mathrm{a}} \mathrm{D}$, quais os que você mais gostou?

Entrevistado: o the Sims, Zoo tycoon e o ...

Entrevistadora: algum da internet você gostou?

Entrevistado: todos.

Entrevistadora: e os da internet também, certo. Já no ano seguinte, em 2008 Thiago, a sua mãe contou para a equipe que algumas vezes você estava se esquecendo, os nomes das pessoas, um fato que acontecia você esquecia, lembra disso?

Entrevistado: não.

Entrevistadora: lembra que você esquecia o nome de algumas pessoas?

Entrevistado: não.

Entrevistadora: e quando acontecia alguma coisa em casa e a sua mãe perguntava e você não sabia contar lembra?

Entrevistado: lembro.

Entrevistadora: lembra? Tem algum exemplo de que você esqueceu?

Entrevistado: não.

Entrevistadora: alguém telefonou e você se esqueceu de dar o recado?

Entrevistado:

Entrevistadora: não lembra não?

Entrevistado: não.

Entrevistadora: mas você lembra da sua mãe reclamar que você esquecia as coisas?

Entrevistado: lembro.

Entrevistadora: você acha, Thiago, que depois que você começou a participar do projeto $5^{\mathrm{a}}$ Dimensão alguma coisa ficou diferente? 
Entrevistado: sim.

Entrevistadora: o quê?

Entrevistado: tudo.

Entrevistadora: na sua vida?

Entrevistado: é, mais ou menos.

Entrevistadora: o que você acha que ficou diferente?

Entrevistado: aí eu não lembro.

Entrevistadora: assim, o seu jeito de ser, você acha que o seu jeito de ser mudou?

Entrevistado: mudou.

Entrevistadora: "hum"... e você ficou como Thiago?

Entrevistado: melhor.

Entrevistadora: ótimo, você ficou melhor no quê? no jogo do Zoo tycoon?

Entrevistado: é.

Entrevistadora: e o que mais?

Entrevistado: no the sims.

Entrevistadora: melhorou no jogo do the sims...

Entrevistado: e em muitas outras coisas...

Entrevistadora: você acha que esse jeito seu de ser, que mudou com a $5 \mathrm{D}$, fora da $5^{\mathrm{a}}$ dimensão você também ficou um garoto mudado?

Entrevistado: sim.

Entrevistadora: na escola? onde?

Entrevistado: na escola, lá em casa, na rua e em outros lugares também.

Entrevistadora: das pessoas que você conheceu aqui, você acha que as pessoas daqui, os amigos que você conheceu, e que você fez, te ajudaram de alguma forma?

Entrevistado: sim.

Entrevistadora: o que eles fizeram pela sua vida?

Entrevistado: muitas coisas.

Entrevistadora: os estudantes... lembra dos estudantes? qual você lembra mais.

Entrevistado: da Thainá.

Entrevistadora: você lembra da sua mania? de ficar sempre com a Tainá? Lembra?

Entrevistado: lembro.

Entrevistadora: por que?

Entrevistado: porque eu gostava dela. 
Entrevistadora: gostava mais dela.... mas tinha outro que você gostava também....

Entrevistado: do Felipe.

Entrevistadora: o Felipe e eles eram estudantes né, você sabe.... sabe que curso eles estavam fazendo? Você sabe que eles estavam em uma faculdade? Sabia?

Entrevistado: sim.

Entrevistadora: e você acha que conviver com os estudantes, jogar com eles, fez alguma mudança na sua vida?

Entrevistado: fez.

Entrevistadora: em qual sentido, Thiago?

Entrevistado: \{termo inaudível\}

Entrevistadora: no que será que eles ajudaram?

Entrevistado: em muita coisa....dever de casa...

Entrevistadora: ah, excelente. No dever de casa... no quê mais?

Entrevistado: no meu trabalho.... em muitas outras coisas também.

Entrevistadora: você acha que as coisas que você tem responsabilidade de fazer em casa, por exemplo, você tem coisas para fazer em casa nas tarefas domésticas?

Entrevistado: sim.

Entrevistadora: quais?

Entrevistado: lavar a louça.

Entrevistadora: você acha que participar da $5^{\text {a }}$ Dimensão, que os estudantes te ajudaram em algum sentido a assumir as tarefas de casa....

Entrevistado: sim.

Entrevistadora: sim. Eu me lembro Thiago, que houve um tempo em que a sua mãe comentou aqui com a equipe, que você estava tendo dificuldade de se organizar. Tinha tarefa para fazer mas você queria jogar Playstation. Como mudou isso, o que você faz para melhorar?

Entrevistado: eu fui estudar.

Entrevistadora: mas você estudou a partir de que hora?

Entrevistado: à noite.

Entrevistadora: então você passou a estudar sempre à noite.

Entrevistado: sim.

Entrevistadora: e qual hora você jogava o Playstation?

Entrevistado: estudava de manhã e jogava à noite.

Entrevistadora: eu fui a uma visita na sua escola uma vez conversar com os professores. Lembra disso?

Entrevistado: lembro, mas eu não estava. 
Entrevistadora: isso, você não "tava" mas foi a primeira vez a gente ia conversar com os professores né, e naquela época, o coordenador ligou para a gente porque viu que você estava tendo dificuldade de aprender as matérias. Como estava isso, Thiago, por que estava difícil?

Entrevistado: tava difícil as matéria...

Entrevistadora: era difícil, sua memória estava falhando, o que é que estava acontecendo?

Entrevistado: a memória estava falhando muito.

Entrevistadora: você não estava jogando Playstation de mais não?

Entrevistado: não.

Entrevistadora: então você acha que era a memória?

Entrevistado: é.

Entrevistadora: e de lá para cá, mudou?

Entrevistado: mudou.

Entrevistadora: nos sugerimos na época uma coisa que você já tinha aprendido aqui!

Entrevistado: o quê?

Entrevistadora: organizar os horários.

Entrevistado: foi.

Entrevistadora: aí você ia ter o quê, hora para estudo, o quê mais?

Entrevistado: hora para jogar e hora para arrumar a casa...

Entrevistadora: e hora para descansar né?

Entrevistado: é.

Entrevistadora: e nessa visita que a gente fez na sua escola, alguns professores contaram que às vezes você fazia brincadeiras que não eram de machucar os colegas, mas eram brincadeirinhas de provocar..

Entrevistado: é.

Entrevistadora: ta lembrando.. e que alguns colegas ficavam até zangados com você.

Entrevistado: foi.

Entrevistadora: você mudou nisso?

Entrevistado: mudei.

Entrevistadora: como você faz para mudar?

Entrevistado: parei com essas brincadeiras.

Entrevistadora: você percebeu que estava incomodando os outros?

Entrevistado: sim. 
Entrevistadora: então me diz... aqui na $5^{\text {a }}$ Dimensão, você também tinha esse comportamento de provocar os colegas?

Entrevistado: não.

Entrevistadora: e também tem um fato que aconteceu há um tempo atrás, que às vezes quando você estava brincando só você e o seu irmão, Lucas, acaba que discutiam os dois, mas quando estava você, o Lucas e outras crianças não tinha discussão. E aqui na $5^{\mathrm{a}}$ Dimensão, como era?

Entrevistado: era.... a gente não brigava não....

Entrevistadora: não, não tinha briga.... por que será Thiago que aqui era diferente quando tinha outros amigos era diferente?

Entrevistado: não sei.

Entrevistadora: pensa um pouquinho, tenta imaginar..

Entrevistado: não sei, não tenho a mínima idéia.

Entrevistadora: não tem a mínima idéia? e lá nessa reunião também na escola, a sua mãe tinha comprado uma agenda para você poder anotar as tarefas. Lembra disso?

Entrevistado: lembro.

Entrevistadora: e você estava conseguindo usar a agenda direito?

Entrevistado: não.

Entrevistadora: por quê?

Entrevistado: era chato ficar anotando toda hora as tarefas.

Entrevistadora: era chato... como que você organizou isso?

Entrevistado: anotando no meu caderno.

Entrevistadora: ao invés de anotar na agenda você passou a anotar no caderno. Ficou melhor?

Entrevistado: ficou.

Entrevistadora: mas não dava no mesmo?

Entrevistado: dava, eu esquecia o que tinha $\{\ldots\}$

Entrevistadora: se não anotasse na agenda, o que podia acontecer Thiago?

Entrevistado: eu esquecia.

Entrevistadora: Thiago, você acha que depois que você veio para 5D, você passou a ser um "cara" diferente, você passou a ser um "cara melhor", você disse que ficou melhor. Antes você não era bom?

Entrevistado: não.

Entrevistadora: como você era...

Entrevistado: chato.

Entrevistadora: chato como Thiago? 
Entrevistado: implicava com todo mundo.

Entrevistadora: ah, você implicava... o quê mais você fazia que chateava as pessoas? Entrevistado: muita coisa...

Entrevistadora: então você era chato e implicava né? e depois, na $5^{\mathrm{a}}$ Dimensão.... Entrevistado: melhorou.

Entrevistadora: aprendeu a não ser chato.

Entrevistado: "anhan".

Entrevistadora: então "ta" bom, ta legal..... tem mais alguma coisa que você gostaria de mudar no seu jeito de ser?

Entrevistado: não.

Entrevistadora: você "ta bacanão"?

Entrevistado: "tô".

Entrevistadora: ótimo. Obrigada Thiago.

Nome: LV - D155273

Unidade: BSB - LN

Entrevistador: na época em que você começou o tratamento lá no Sarah - Lago Norte, você estudava em uma Escola no Guará. Lembra a série que você estava?

Entrevistado: na $5^{\mathrm{a}}$.

Entrevistador: e como estava o seu rendimento na escola?

Entrevistado: ruim.

Entrevistador: agente viu no prontuário, lendo a sua história, que antes de você ter ido para o Sarah fazer o tratamento, nos anos anteriores você estava tendo um baixo rendimento na escola. Você se lembra por que tinha esse baixo rendimento?

Entrevistado: Não lembro.

Entrevistador: não lembra o que provocava esse baixo rendimento?

Entrevistado: a bagunça.

Entrevistador: sim, no prontuário tem relato de que você contou que a sua tia contou que os professores se queixavam algumas vezes que você conversava, brincava e isso você acha que atrapalhava mesmo o seu rendimento?

Entrevistado: atrapalhava. 
Entrevistador: então os professores tinham razão né? ta! Quando a Ana Luisa te convidou para participar do Projeto $5^{\text {a }}$ Dimensão, você se lembra do primeiro dia, das primeiras vezes?

Entrevistado: não.

Entrevistador: lembra como era a sala?

Entrevistado: lembro.

Entrevistador: como?

Entrevistado: tinha computadores, videogame, tinha uns meninos lá que ficavam com a gente e só.

Entrevistador: e jogos de mesa de tabuleiro, tinha?

Entrevistado: tinha vários. Dama, dominó, um "bocado" tinha lá, xadrez, tinha um monte.

Entrevistador: você acha, Lucas, como disse ali no seu texto, você acha que participar do grupo $5^{\mathrm{a}}$ Dimensão foi bom?

Entrevistado: foi.

Entrevistador: Porquê?

Entrevistado: foi muito divertido, aprendi muitas coisas e gostei do pessoal.

Entrevistador: o que você acha que aprendeu lá?

Entrevistado: muitas coisas.

Entrevistador: vamos tentar lembrar alguma coisa legal que você aprendeu....

Entrevistado: aprendi a compartilhar com os amigos, ajudar os amigos e só.

Entrevistador: você já sabia jogar todos aqueles jogos?

Entrevistado: alguns. Aprendi a jogar também com a Fernanda e com um "bocado" de gente lá.

Entrevistador: quem era Fernanda?

Entrevistado: uma menina que estava lá com a gente.

Entrevistador: estudante?

Entrevistado: era.

Entrevistador: ah, universitária.

Entrevistado: "ahhannn"

Entrevistador: o que você aprendeu a jogar com ela?

Entrevistado: um "bocado" de jogo do Playstation, computador; com ela, com o Adriano, "maior legal" os meninos de lá.

Entrevistador: é, eu me lembro deles também. Mas eu lembro Lucas, que uma das coisas que quando você falou que aprendeu a compartilhar com os amigos, antes você não sabia compartilhar? 
Entrevistado: sabia, mas lá foi melhor.

Entrevistador: eu concordo com você; você já sabia compartilhar. Quando você estava sendo acompanhado no $5^{\text {a }}$ Dimensão, a Carol, professora, sugeriu algumas estratégias para você conseguir estudar melhor e aproveitar melhor o estudo. Lembra como foi isso?

Entrevistado: não.

Entrevistador: Ela te orientou, te ajudou a organizar o seu dia.

Entrevistado: Ah, lembro, ela passou uma tabela para mim, para me organizar e aí tinha que "botar" aquilo que tinha que fazer nos dias, a matéria, um "bocado" de coisas.

Entrevistador: era um planejamento do estudo. Isso funcionou?

Entrevistado: funcionou no começo, depois parei de fazer.

Entrevistador: e depois que você parou de fazer, atrapalhou tudo?

Entrevistado: voltou do jeito que era antes.

Entrevistador: como era antes?

Entrevistado: bagunçado.

Entrevistador: então, enquanto você seguia o planejamento de estudo foi bacana?

Entrevistado: foi, ficou melhor um pouco.

Entrevistador: ta! hoje que você estuda, de manhã ou de tarde?.

Entrevistado: de manhã.

Entrevistador: começa que horas e termina que horas?

Entrevistado: começa às 8 e acaba ao meio-dia.

Entrevistador: que série você está fazendo?

Entrevistado: $8^{\mathrm{a}}$.

Entrevistador: é o nono ano. E o resto do dia, o que é que você faz?

Entrevistado: eu faço o curso, de $2 \mathrm{~h}$ às 6 horas.

Entrevistador: de segunda a sexta?

Entrevistado: é!

Entrevistador: qual o curso?

Entrevistado: técnico em suporte.

Entrevistador: é na área de informática né?

Entrevistado: é.

Entrevistador: e no fim de semana?

Entrevistado: no fim de semana vou brincar.

Entrevistador: então... 
Entrevistado: saio com o meu primo, vou para a casa da minha irmã e só.

Entrevistador: de manhã você estuda na escola e quando tem fazer tarefa, pesquisa... Entrevistado: em casa, à noite, às vezes nunca...

Entrevistador: às vezes você deixa de fazer trabalho?

Entrevistado: por causa da preguiça.

Entrevistador: de que forma você acha que pode resolver isso hoje?

Entrevistado: não sei.

Entrevistador: numa planilha, com a divisão das tarefas...?

Entrevistado: é, sei lá.

Entrevistador: não tinha pensado nisso não? antes de você entrar na 5D, você acha que conseguia se perceber mais, olhar para você mais, conhecer você, ou isso você aprendeu depois, depois que participou da 5D?

Entrevistado: é, também. Antes e depois era a mesma coisa, mas depois ficou um pouco melhor né?

Entrevistador: antes você ouvia as pessoas te dizerem que você precisava ler mais?

Entrevistado: ouvia.

Entrevistador: depois da 5D você passou a ler mais?

Entrevistado: mais ou menos.

Entrevistador: só aquilo que passa na escola?

Entrevistado: é.

Entrevistador: você falou né Lucas, que com a entrada na $5 \mathrm{D}$ você percebeu que começou a participar mais das coisas, com os amigos lá dentro e tudo. De que forma você acha que a $5 \mathrm{D}$, projeto, contribuiu para isso? O que acontecia lá? o que acontecia que contribuiu para ocorrer.... não foi uma mudança, que você já era assim, mas você falou que começou a fazer isso mais vezes, ficou melhor. O que você acha que contribuiu para isso?

Entrevistado: porque lá tinha muita gente que tinha vezes em que eu sabia coisas a mais que os meninos lá, aí eles vinham, me perguntavam e eu sempre ajudava eles, "tipo" ajudava o próximo. Sempre ajudei eles e gostava ajudar os meninos de lá.

Entrevistador: você acha que lá tinha mais oportunidades ou as pessoas te buscavam mais para pedir ajuda.... o que é era diferente?

Entrevistado: é, me buscavam e viam como que eu podia ajudar eles lá dentro do projeto lá.

Entrevistador: e você se sentida de um jeito diferente quando você estava lá dentro, quando você estava no projeto e quando você estava no em outros lugares, como por exemplo, na escola?

Entrevistado: não. 
Entrevistador: da mesma forma?

Entrevistado: é.

Entrevistador: o que mudava então?

Entrevistado: nada. Lá era melhor porque tinha muitas pessoas assim, que eu sei que alguns gostavam de mim e tudo e lá era muito bom.

Entrevistador: você se sentia bem com pessoas que gostavam de você.

Entrevistado: era.

Entrevistador: você acha, Lucas, que depois da entrada no Projeto, com essa característica de ajudar os amigos, de cooperar, que você se viu fazendo mais isso, você acha que começou a usar isso em mais outro lugar ou fora da 5D continua da mesma forma.

Entrevistado: sempre quando alguém precisa de mim eu "tô" ajudando mas é como sempre, "tipo" algumas pessoas precisam de mim e aí eu ajudo, normal, do mesmo jeito que eu era lá sou com todo mundo.

Entrevistador: e você aprendeu mais alguma coisa lá no projeto?

Entrevistado: não, só isso mesmo, de ajudar o próximo e compartilhar.

Entrevistador: e sobre você mesmo, você aprendeu alguma coisa?

Entrevistado: não.

Entrevistador: de como você acha que você é, suas características, você acha que começou a ver de um jeito diferente, aprendeu alguma coisa nova sobre você.

Entrevistado: não.

Entrevistador: Lucas, você acha que antes de você ir para a $5 \mathrm{D}$, você já tinha percebido essa sua característica de ser um "cara" bom, que colabora e que ajuda? Você já tinha percebido isso antes?

Entrevistado: não.

Entrevistador: então foi lá que você teve a oportunidade?

Entrevistado: foi.

Entrevistador: Lucas, você disse que aprendeu muitas coisas com o Adriano, com a Fernanda, que eram estudantes universitários que jogavam com vocês no espaço da 5D. Você acha que foi "bacana" ter esses amigos universitários lá?

Entrevistado: foi muito bacana, gostei.

Entrevistador: você acha que eles são pessoas que serviriam de exemplo para você como estudantes?

Entrevistado: sim. 
Entrevistador: OK! você acha que essa amizade com eles, essa oportunidade de jogar, o fato deles serem universitários, você acha que isso ajudou você a perceber essa característica sua de ser um "cara" amigo, participativo...?

Entrevistado: é, acho que sim também.

Entrevistador: obrigada, Lucas. Acho que deu né....

Entrevistado: até hoje tenho comunicação eles, com o Adriano, com a Fernanda no Orkut, no MSN e só.

Nome: GCB - D162159

Unidade: BSB-LN

Entrevistadora: Gabriel, quando você entrou na $5^{\mathrm{a}} \mathrm{D}$, você tinha algumas dificuldades no dia a dia, em algumas situações específicas, então você entrou, começou a fazer parte do projeto. O que nós gostaríamos de saber, primeiramente, é se você se lembra quais eram suas dificuldades, o que você percebia de você naquela época que entrou na $5^{\mathrm{a}} \mathrm{D}$ ? Entrevistado: Percebi que era uma pessoa muito fechada, não falava muito, acho que tinha vergonha de falar, muitas vezes. Acho que a partir que eu entrei na $5^{\mathrm{a}} \mathrm{D}$, acho que continuei o mesmo, mas, tipo que nem na escola, eu tenho uma dúvida, eu falo com o professor, e isso eu não falava antes, tinha vergonha.

Entrevistadora: Você tava dizendo da dificuldade em relação ao professor, de perguntar as dúvidas?

Entrevistado: Quando eu entrei, acho que a partir disso, eu comecei a falar mais, sem ter medo de falar, assim, se falar besteira, foi, é isso; coisa que eu aprendi, eu acho, a falar.

Entrevistadora: De que forma você acha que o projeto e as atividades te ajudaram? Como?

Entrevistado: Acho que foi conversando com os estagiários, comecei a conversar mais, percebi que não é bobeira falar, vergonha. Você tem que falar mesmo o que você pensa, o que você acha.

Entrevistadora: Você acha que você está ficando mais livre para expressar o que você pensa?

Entrevistado: sim.

Entrevistadora: Mais tranquilo para falar o que você acha das coisas? É isso?

Entrevistado: Sim

Entrevistadora: A partir da relação com os estudantes?

Entrevistado: Sim, e também as conversar, né? Tipo, eu relacionava até a vida um do outro, o estudo muitas vezes, o que tem adiante, né? Eles me passaram também experiências.

Entrevistadora: Os estudantes?

Entrevistado: Que eles passaram assim, depois, de Ensino Médio, que eu tô agora. 
Entrevistadora: Você acha que a experiência deles como estudantes recém-saídos do Ensino Médio te ajudou?

Entrevistado: Acho que sim

Entrevistadora: Legal.

Entrevistado: Acho que é isso.

Entrevistadora: Gabriel, você lembra se quando você entrou no projeto, você tinha alguns momentos de dificuldade de memória, dificuldade de se lembrar de algumas coisas, isso acontecia com você?

Entrevistado: Acho que não, porque, Não sei.

Entrevistadora: Você não se lembra ou acha que não acontecia?

Entrevistado: Acho que não aconteceu não.

Entrevistadora: Tinha algumas dificuldades na escola, assim, em relação ao estudo, foi feita uma visita na sua escola, conversado com os seus professores, e combinaram algumas coisas, né? Parece que foi combinado de seus pais te ajudarem um pouco no estudo. Foi isso que aconteceu?

Entrevistado: Sim. Acho que minha mãe, muitas vezes eu converso com ela, porque eu estudo, ela me ajuda um pouco, até uma vez ela arrumou um amigo, não é amigo assim, é tipo...

Entrevistadora: Colega.

Entrevistado: É colega, para tirar dúvidas. Ele sabia mais a matéria que eu estava com dificuldade, que era matemática e ele me ajudava a tarde toda a estudar matemática e deu certo, né? No final do ano eu consegui passar em matemática, principalmente, que eu estava com dificuldade.

Entrevistadora: Você acha que o que mais contribuiu para você passar na matéria de matemática, o que foi?

Entrevistado: Ajuda também. Ajudava muito.

Entrevistadora: Você acha que neste ponto a $5^{\mathrm{a} D}$ ajudou em alguma coisa ou não?

Entrevistado: Acho que sim, é porque eu nunca levei assim material, mas eles falavam, vem para cá, trás material que eu vou te ajudar.

Entrevistadora: Você não trazia?

Entrevistado: Não, eu não trazia.

Entrevistadora: Você aproveitava para fazer outras coisas?

Entrevistado: É.

Entrevistadora: $\mathrm{O}$ que você gostava de fazer na $5^{\mathrm{a}} \mathrm{D}$ ?

Entrevistado: Conversar mesmo, conversar experiências, né? O que eles têm a passar para mim, talvez, daqui a pouco, eu tô saindo do Ensino Médio. 
Entrevistadora: Você acha que o convívio com os estudante foi bom pela experiência deles como estudante, é isso?

Entrevistado: Sim .

Entrevistadora: Legal. Você lembra se no começo, quando você entrou, se era um pouco mais difícil você dizer o que você queria ou o que você não queria? Dizer que você não queria alguma coisa ou queria alguma coisa? Ter iniciativa para propor uma atividade? Você se lembra se no começo isso acontecia com você?

Entrevistado: Sim, acontecia. Acho que até acontecia muito mais assim, porque eu já era uma pessoa tipo, com idade já que aquelas atividades não se encaixavam muito, e tal, mas eu ia, brincava, só para divertir, tudo bem, mas.

Entrevistadora: Você achava que as atividades não tinham muito a ver?

Entrevistado: É, mas era legal.

Entrevistadora: Você acha que isso acontecia em outras situações, mesmo com atividades legais, assim, em situações fora do projeto, por exemplo, de você não falar muito a sua opinião, o que você queria, o que você não queria. Acontecia isso fora? Sem ser na $5^{\mathrm{a} D}$ ?

Entrevistado: Acontecia o que?

Entrevistadora: Isso de você não conseguir falar muito o que você queria ou o que você não queria, o que você achava das coisa, fora da $5^{\mathrm{a}} \mathrm{D}$ ?

Entrevistado: Acho que sim. As vezes tinham algumas situações que eu não conseguia falar o que eu queria. Eu não conseguia falar, eu ficava calado também. Tipo, as vezes assim, dá vontade de falar, mas, tipo, que nem na escola, um fala, o outro fala e eu acabo desistindo um pouco de falar também.

Entrevistadora: Você acha que isso mudou ou continua?

Entrevistado: Acho que mudou um pouco, né? Acho que tento falar, principalmente quando não dá.

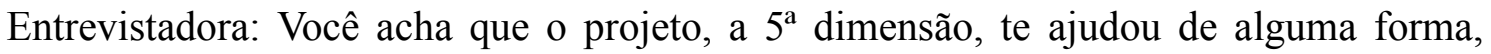
como o projeto contribuiu para essa mudança?

Entrevistado: para mudança, não tenho idéia. Acho que a falar e escrever bem, me ajudou a me expressar, acho que é isso.

Entrevistadora: Tinha algumas situações também Gabriel, de você as vezes sair com alguns amigos adolescentes e se perder, pegar o Ônibus e não saber direito, umas situações meio arriscadas, acontecia isso também naquela época?

Entrevistado: Acho que não, porque sempre quando eu saía eu ia com alguém, né? De confiança e tal e assim, eu não sou muito de andar de ônibus, essas coisas, mas ele, o amigo, sabe bem, eu nunca tive uma situação dessa não.

Entrevistadora: De você se perder? Ou de ficar com alguns amigos que preocupavam seus pai e sua mãe?

Entrevistado: Não.

Entrevistadora: Não? Não acontecia isso? 
Entrevistado: Não.

Entrevistadora: Então tá. Me conta uma coisa, o que mais você aprendeu no Projeto, o que mais que foi importante, interessante para você no Projeto da $5^{\text {a }}$ dimensão?

Entrevistado: No projeto? Acho que foi a experiência que eles passaram para mim que mostra que eu tenho que estudar, agora, principalmente. Também tem altas situações que você vê que eu necessito, tá entendendo?

Entrevistadora: O que por exemplo?

Entrevistado: Não, tipo, tem umas situações aí que a gente vê que, esqueci a pergunta.

Entrevistadora: Eu perguntei para você se o projeto, as atividades, o que você fez aqui na $5^{\text {a }}$ dimensão contribui para mais alguma coisa na sua vida? Foi importante para mais alguma coisa?

Entrevistado: Acho que foi isso que eu falei anteriormente, para mim foi importante a minha participação.

Entrevistadora: Tem mais alguma coisa que você queira falar, comentar sobre a sua participação no Projeto?

Entrevistado: Não.

Entrevistadora: E como é que você está hoje?

Entrevistado: Eu estou bem, assim, em comparação aos outros eu sou uma pessoa que pode se dizer normal, né? Coisa que, no início de meu acidente eu não achava, achava que eu era diferente, me tornara diferente e hoje eu vejo que sou uma pessoa normal e faço coisas normais.

Entrevistadora: Que todo o adolescente faz, é isso?

Entrevistado: É.

Entrevistadora: E você acha que começou a sentir assim ou passou a sentir assim depois do acidente? De que forma, o que contribuiu para isso?

Entrevistado: eu acho que, eu me achava diferente, principalmente porque eu gostava muito de jogar futebol, de sair né? Eu tinha quebrado a perna, eu me achava muito estranho, ficava muito desanimado com as coisas, e depois, assim, eu comecei a entender, eu também me achava ainda diferente, mas eu acho que achei diferente porque sofri o acidente e nem todas as pessoas sofrem acidente com eu, na minha idade, fui levando aí, acho que eu tô aprendendo, o verdadeiro significado que eu sou normal, sou um cara..

Entrevistadora: Você voltou a jogar futebol?

Entrevistado: sim.

Entrevistadora: Ah, legal, tá certo, tem mais alguma coisa que você queira falar? Entrevistado: não.

Entrevistadora: então tá, obrigada, viu? Obrigada pela sua participação. 
Nome: R

Unidade: BSB - LN

Entrevistadora: Rodrigo, a gente estava comentando aqui que o seu irmão falou que, às vezes, você fala de outro assunto diferente do que as pessoas estão conversando. Foi isso que ele te falou?

Entrevistado: Sim.

Entrevistadora: Por que você acha que isso acontece? Como que é?

Entrevistado: Tipo, meu irmão, por exemplo, está falando como jogar vôlei e eu penso em outro: "que tal a gente jogar espirobol, jogar handebol ou surfar?"

Entrevistadora: Você acha que isso acontece porque é difícil lembrar das coisas das quais as pessoas estão falando?

Entrevistado: Como assim?

Entrevistadora: Por exemplo, o seu irmão está falando de futebol, que foi o exemplo que você deu. É difícil ficar acompanhando tudo o que ele fala? Você acha que ele fala demais?

Entrevistado: Não. Eu acho que ele é muito inteligente.

Entrevistadora: Rodrigo, estávamos falando que você acha o seu irmão é muito inteligente.

Entrevistado: Sim.

Entrevistadora: E o que acontece então nessa hora, em que é difícil acompanhar o que ele está falando?

Entrevistado: Mas como assim?

Entrevistadora: Um exemplo que você falou: ele está falando de futebol e você vem com a ideia de falar do espirobol ou do handebol e eu te perguntei: "você acha que o seu irmão fala demais?" Você falou: "não. Acho que ele é muito inteligente". Então, o que acontece que você não consegue acompanhar o que ele está falando? Porque você começa a falar de handebol se ele está falando de futebol?

Entrevistado: Porque aparece na minha cabeça outro esporte.

Entrevistadora: É uma coisa que surge na sua cabeça?

Entrevistado: É como se fosse o mundo da imaginação. Vem uma nova coisa, tipo, eu to falando sobre...

Entrevistadora: Rodrigo, estávamos comentando sobre quando o seu irmão ta falando no assunto, e as vezes vem uma imaginação na sua cabeça e você começa a falar de outro assunto, por exemplo, outro esporte. Você falou que seu irmão é muito inteligente, que você não acha que ele fala demais, ele fala o que precisa, né?

Entrevistado: Ele pensa demais e gosta de estudar muito. 
Entrevistadora: Você também pensa demais?

Entrevistado: Pra dizer, pode ser, é, eu penso.

Entrevistadora: $\mathrm{O}$ que acontece quando alguém está falando e você não consegue acompanhar o que essa pessoa fala? Você acha que é difícil acompanhar o que a pessoa fala?

Entrevistado: É, acho que sim.

Entrevistadora: Será que é difícil lembrar de tudo o que ela fala?

Entrevistado: sim.

Entrevistadora: Como se chama isso?

Entrevistado: Não tenho a mínima ideia.

Entrevistadora: O que você acha que é difícil para você?

Entrevistado: $\mathrm{O} 9^{\circ}$ ano.

Entrevistadora: Na escola, é difícil?

Entrevistado: Isso.

Entrevistadora: Por que?

Entrevistado: Porque só cai coisas novas, que eu não sei, coisas difíceis, que eu não sei, que eu não consigo fazer.

Entrevistadora: Deixa eu te perguntar uma coisa, você participa do projeto $5^{\text {a }}$ dimensão, não é? Há bastante tempo, faz alguns anos. Ao longo de sua participação aqui na $5^{\text {a }}$ dimensão você conheceu muitos amigos, não foi?

Entrevistado: Sim.

Entrevistadora: Mais ou menos quantos amigos você acha que fez aqui?

Entrevistado: Milhares.

Entrevistadora: Deve ser difícil lembrar o nome de todos esses amigos, né?

Entrevistado: Sim.

Entrevistadora: E como é que você faz para lembrar o nome de todo mundo?

Entrevistado: Eu paro, olho bem para pessoa, entro na minha mente, penso, luto para poder saber, pergunto com que letra começa o nome da pessoa, por exemplo, se for Juliana, eu falo, com que letra começa? Então falo "J", então penso: "J”, aí chuto.

Entrevistadora: Então você usa uma estratégia?

Entrevistado: Sim.

Entrevistadora: Isso é muito bom! Por exemplo, quando estávamos naquele grupo de esportes, lembra do Mateus? Que tinha uma deficiência auditiva e utilizava sinais para .... pessoas. Você acha que isso pode te ajudar?

Entrevistado: Pode ser. 
Entrevistadora: ou a primeira letra do nome? Ou como você falou, você olha bem para pessoa e tenta ver uma característica dela?

Entrevistado: sim.

Entrevistadora: me fala o nome de alguém da $5^{\mathrm{a}} \mathrm{D}$, que você gravou assim?

Entrevistado: Elder.

Entrevistadora: Como você gravou o nome do Elder?

Entrevistado: De vê ele muitos dias, de conversar com ele muito e de conhecer um dia os pais dele, a irmã e tudo.

Entrevistadora: Quando você fala o nome "Elder" você lembra de todas as vezes que você encontrou com ele, dos pais dele, da irmã dele? É isso? Como se fosse fazendo uma imagem na sua cabeça?

Entrevistado: Não.

Entrevistadora: Não tem imagem?

Entrevistado: Não.

Entrevistadora: Eu me lembro que quando você entrou na $5^{a}$ dimensão, você gostava muito de abraçar as meninas, ficar elogiando, dando alguns galanteios e às vezes elas não gostavam e te pediam para parar? Isso acontecia?

Entrevistado: Sim.

Entrevistadora: E como era?

Entrevistado: Só que agora eu já notei que isso é errado e agora, devo perguntar para ela se posso ou não dar um beijo na bochecha, como se fosse dando um "oi".

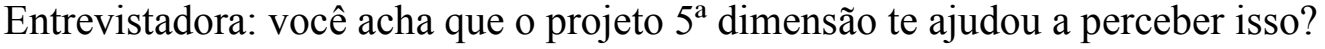

Entrevistado: Sim.

Entrevistadora: As próprias estudantes falaram isso para você, que era legal perguntar antes de beijar?

Entrevistado: Sim.

Entrevistadora: Eu assisti a um filme que tinha você e outra adolescente aqui no Sarah, que você fizeram um tipo de festas de adolescentes e filmaram, falando sobre esse comportamento que não se pode chegar assim abraçando e beijando, você lembra desse filme?

Entrevistado: lembro.

Entrevistadora: E como que era?

Entrevistado: Tinha um monte de gente em volta, tipo eu ligava o som, eu ficava dançando, quando o som acabava eu ia abraçar ela, aí ela me empurrava, eu fingia que tinha caído no chão, acho que só me lembro disso.

Entrevistadora: Tem muitas coisas aqui na $5^{a}$ Dimensão, né? É difícil lembrar de tudo? Entrevistado: Sim. 
Entrevistadora: Na escola, também é difícil lembrar?

Entrevistado: Mais ou menos.

Entrevistadora: Me dá um exemplo do que é difícil lembrar:

Entrevistado: Produtos notáveis, fórmula de Bhaskara, equação de segundo grau.

Entrevistadora: O que você faz para te ajudar a lembrar?

Entrevistado: Eu volto nas matérias que o professor passou, tipo, chego na aula que o professora passou sobre Bhaskara, vejo lá como é que é, volto, faço e lembro.

Entrevistadora: Então tem que está tudo escrito?

Entrevistado: Sim.

Entrevistadora: Você aprendeu mais alguma coisa no Projeto $5^{\mathrm{a}}$ Dimensão? Tenta lembrar desde a época que você entrou no Projeto, as pessoas que você conheceu. O que você aprendeu no Projeto $5^{\mathrm{a}}$ Dimensão?

Entrevistado: Eu aprendi que quando alguém que jogar, você pergunta para ela se ela gostaria de jogar com você ou não para fazer uma parceria a ela.

Entrevistadora: Você aprendeu então a interagir com as pessoas? Se aproximar?

Entrevistado: Sim.

Entrevistadora: E essa coisa de você ter estratégia para lembrar o nome das pessoas, escrever para lembrar o que acontece, foi uma coisa que você também aprendeu aqui na $5^{\text {a }}$ Dimensão?

Entrevistado: Foi.

Entrevistadora: As estudantes te ajudavam também com a escola?

Entrevistado: Ajudavam.

Entrevistadora: Você fazia dever aqui, como é que era?

Entrevistado: Tipo, quando eu precisava de ajuda em inglês, eu perguntava para elas, já que elas eram formadas e elas me ajudavam em inglês. O Adriano, que ele já se formou em matemática, só que ele não gostou e passou para outro, ele se lembrou um pouco da matemática, ele me ajudou na matemática.

Entrevistadora: Você falou o nome de um estudante, o Adriano. Como você aprendeu o nome dele? Você pegou alguma característica ou estratégia para lembrar do nome dele? Entrevistado: Sim.

Entrevistadora: Qual?

Entrevistado: Do jogador do Flamengo, Adriano, muito famoso, todo mundo conhece.

Entrevistadora: Então toda vez que você olha para Adriano, o estudante, você lembra de um jogador famoso do Flamengo que também chama Adriano.

Entrevistado: Eu lembro do nome, mas não me lembro do jogador. Eu lembro do nome Adriano e me lembro do Adriano. 
Entrevistadora: Entendi. Essa estratégia de lembrar o nome de pessoas famosas é bem interessante, né? Você costuma fazer isso com outros nomes? Por exemplo, tem uma terapeuta aqui no Setor que chama Bruna e ela me falou que você sempre lembra o nome dela porque você associa com Bruna Lombardi, é isso?

Entrevistado: Não. Eu associo com o nome do meu irmão, Bruno, só que coloco o nome do meu irmão no feminino, então me lembro.

Entrevistadora: Interessante. Você lembra o nome de mais alguma estudante?

Entrevistado: Lembrar assim, lembro da Lorena.

Entrevistadora: Como você fez para aprender o nome da Lorena?

Entrevistado: eu me apaixonei por uma menina que estudou comigo desde o prezinho até a $4^{\text {a }}$ série, quando eu parei de estudar. Até a $4^{\text {a }}$ ? É. Foi o último dia que eu pude ver ela, por que eu fiz até a $4^{\circ}$, voltei dois anos, ela foi passando, chegou no $9^{\circ}$ ano, se formou no ensino fundamental e agora eu acho que ela está no $3^{\circ}$ ano do ensino médio. Eu me lembro do nome da Lorena por causa dela.

Entrevistadora: E tem alguma outra estudante que você lembrou agora, ou alguém aqui da Equipe?

Entrevistado: A Juliana, porque tem uma menina da minha sala que eu estudo, que o nome dela é Juliana, e, desta Juliana da minha escola, eu gosto muito e eu penso nela e lembro de você e de outras Julianas.

Entrevistadora: Tem mais alguma coisa que você quer falar sobre o Projeto $5^{\text {a }}$ Dimensão, Rodrigo? O projeto te ajudou em mais alguma coisa?

Entrevistado: Sim. O Projeto $5^{\text {a }}$ Dimensão deu para gente uma blusa e isso me fez interagir de saber que tudo pode ser, que eu posso viver. Não, a $5^{\text {a }}$ Dimensão me trouxe harmonia, por me dar de presente está $5^{\mathrm{a}} \mathrm{D}$.

Entrevistadora: Legal. Então você quer continuar no Grupo? Só que agora é $5^{\mathrm{a}} \mathrm{D}$ Esportes? Quer continuar vindo aqui?

Entrevistado: Quero. Agora eu to achando o máximo, a $5^{\mathrm{a}} \mathrm{D}$ Esportes, porque todo mundo combinou de ser canoagem e canoagem você tem que fazer muita força para remar e neste ato de remar, isso pode me ajudar muito bem no braço, no meu lado esquerdo motor, que eu perdi no momento do acidente que eu sofri, que eu tive que vir para cá, para o Sarah, para eu poder retornar o meu jeito pessoal.

Entrevistadora: Você acha que a 5 D também te ajuda a lidar melhor com as dificuldades?

Entrevistado: Sim.

Entrevistadora: Por exemplo, essa dificuldade de lembrar o nome das pessoas, de lembrar das coisas, você acha que o Projeto te ajuda também?

Entrevistado: também.

Entrevistadora: Então ta bom, acho que é isso, né? Mais alguma coisa?

Entrevistado: Não.

Entrevistadora: Muito obrigado pela sua participação. 
Entrevistado: De nada.

Nome: LS

Unidade: BSB - LN

Entrevistadora: Lucas, você acabou de me dizer que acha legal vir para a 5D, o projeto $5^{\text {a }}$ Dimensão. Porque você acha que é bom? Você gosta?

Entrevistado: Gosto.

Entrevistadora: Do que você gosta?

Eu me lembro, Lucas, que logo que você começou na $5^{\text {a }}$ Dimensão, você estava tendo algumas dificuldades na escola, e você lembra disso?

Entrevistado: Não.

Entrevistadora: A gente lembra, por exemplo, que na hora de você criar uma história, produzir um texto, você tinha dificuldade, fazia um texto muito pequeno, e nós te demos uma idéia naquela época, que era de você seguir os passos, você lembra, para conseguir fazer o texto?

Entrevistado: Sim.

Entrevistadora: Era um roteiro, aqueles passos eram um roteiro.

Tem uma coisa também que a gente soube lá no comecinho, quando você começou a ser acompanhado e fazer amigos aqui, que a sua irmã te ensinou como você andar nas ruas perto da sua casa. Nem foi a gente, foi a sua irmã, quais as dicas que ela te deu naquela época?

Entrevistado: Eu não me lembro não.

Entrevistadora: Não? A gente lembra que ela te orientou assim, "passa na frente de tal coisa, tem um comércio aqui", lembrou, "tem o barzinho ali". Não? Então deixa eu ver se eu te ajudo em outra coisa. Essa história de eu não me lembro ainda é uma coisa que acontece hoje?

Entrevistado: Não.

Entrevistadora: Que ótimo.

Você acha que não acontece como antes o "não me lembro". O que será que aconteceu? Entrevistado: Sei não.

Entrevistadora: O que será que fez mudar a sua memória?

Entrevistado: Sei não.

Entrevistadora: Não?

A gente faz alguns trabalhos, alguns jogos aqui na $5^{\text {a }}$ Dimensão, brincadeiras né. Quais as que você acha mais legais?

Entrevistado: Fazer esporte... 
Entrevistadora: Esporte, que mais?

Entrevistado: Jogar no computador.

Entrevistadora: Computador.

Entrevistado: E conversar com as pessoas.

Entrevistadora: Sobre o quê você gosta de conversar aqui?

Entrevistado: Sobre o colégio, sobre o SARAH aqui, sobre as professoras...eu acho que só isso.

Entrevistadora: Professoras lá da sua escola?

Entrevistado: É.

Entrevistadora: Sobre a sua vida né?

Entrevistado: É.

Entrevistadora: O que mais, sobre você, sobre a sua vida, o que você gosta de conversar aqui?

Entrevistado: Eu não gosto muito de conversar não.

Entrevistadora: Aí você aproveita os jogos né, os jogos do computador.

Entrevistado: É.

Entrevistadora: Qual você acha mais legal do computador, qual jogo você curte mais?

Entrevistado: Jogo de corrida.

Entrevistadora: E tem mais um em segundo lugar.

Entrevistado: O de luta.

Entrevistadora: E dos esportes?

Entrevistado: O jogo? O de carro, corrida.

Entrevistadora: Dos esportes, das atividades de esporte, quais você mais gosta?

Entrevistado: Futebol, basquete, remo, quase todos.

Entrevistadora: É muito bacana, quase todos os esportes. Remo é uma coisa nova né? Entrevistado: É.

Entrevistadora: E o que você achou, achou que no começo ia gostar ou você acha que no começo você...

Entrevistado: No começo eu pensei que não ia gostar não, pensei que era chato.

Entrevistadora: E o que te fez mudar de idéia?

Entrevistado: Eu vi que era bom.

Entrevistadora: Como você viu que era bom, como você descobriu?

Entrevistado: Eu não sei explicar não. 
Entrevistadora: Os colegas sugeriram ir para o rio, para a canoagem, mas você acabou indo, não foi?

Entrevistado: Foi.

Entrevistadora: E foi lá que você descobriu que era legal?

Entrevistado: É.

Entrevistadora: Foi fazendo?

Entrevistado: Foi.

Entrevistadora: Ah, então primeiro você foi, experimentou e gostou.

O Lucas, e as outras coisas que a gente fazia lá na sala de recreio, você entrava no jogo do computador, jogava Playstation, essas coisas, você gosta, então você se divertia não é?

Entrevistado: É.

Entrevistadora: Você acha que elas te fizeram um pouco diferente?

Entrevistado: Sim.

Entrevistadora: Como?

Entrevistado: Os jogos que eu não sabia botar na Internet aí me ensinaram.

Entrevistadora: Ah, é mesmo, eu me lembro de você ter falado isso uma vez. Você aprendeu... aprendeu o quê? a entrar no jogo, como é que é?

Entrevistado: Botar a Internet no jogo.

Entrevistadora: Ah, tá. O que mais você...

Entrevistado: Sei não.

Entrevistadora: Você aprendeu a ligar o computador, entrar na Internet e jogar.

Entrevistado: É.

Entrevistadora: Porque antes você não tinha usado computador não.

Entrevistado: É.

Entrevistadora: Nesses jogos algumas coisas são escritas, não são?

Entrevistado: É.

Entrevistadora: E você precisava de alguma ajuda?

Entrevistado: Precisava, porque tinha algumas palavras lá que eu não sabia, como eu não sabia ler direito.

Entrevistadora: É, em inglês ou português?

Entrevistado: Português, inglês também.

Entrevistadora: E você acha que também ajudou né?....

Entrevistado: É. 
Entrevistadora: Lucas, uma vez a sua mãe falou que achava que você estava mais alegre, que você tava animado como você era antes, como você sempre foi. Você concorda com ela?

Entrevistado: Sim.

Entrevistadora: Você acha que está mais animado?

Entrevistado: É.

Entrevistadora: E você acha que foi ficando mais animado por que, de que jeito?

Entrevistado: Porque eu tinha coisas para brincar, essas coisas, porque aqui as pessoas tratam "eu" bem, e eu gostava de vir brincar.

Entrevistadora: Que bom as pessoas tratarem a gente bem, a gente se sente melhor não é.

Entrevistado: É, em casa eu não tinha nada o que fazer aí eu gosto de vir para cá.

Entrevistadora: E quando você quer fazer uma atividade, mas aquela atividade não pode ser naquela hora, como é que é isso para você?

Entrevistado: Tem que esperar a hora que der para "coisar".

Entrevistadora: Antes você já sabia fazer isso, esperar a hora?

Entrevistado: Não.

Entrevistadora: Não?

Entrevistado: Ficava agoniado para fazer logo o que eu queria.

Entrevistadora: Ficava agoniado. E quando foi que você começou a não ficar mais agoniado?

Entrevistado: Depois que comecei a vir para o SARAH.

Entrevistadora: Você lembra o que te ajudou aqui no SARAH a não ficar mais agoniado com as coisas que não eram do jeito que você queria?

Entrevistado: Vocês falaram para eu ter mais paciência, que quando tiver a hora certa aí dá para fazer o que eu quero, que tudo tem a hora certa de fazer.

Entrevistadora: Foi alguém que falou isso, foi uma atividade, como é que foi que falaram isso para você?

Entrevistado: Foi na atividade.

Entrevistadora: Você lembra quem?

Entrevistado: Não.

Entrevistadora: Ou foram várias pessoas.

Entrevistado: Foram várias pessoas.

Entrevistadora: Porque às vezes a pessoa fala "não, tenha paciência", "espera um pouco", e a gente não consegue, né?

Entrevistado: É. 
Entrevistadora: Como que você fez no dia de fazer a votação?

Entrevistado: Fez como assim?

Entrevistadora: Você queria um jogo e o grupo queria outro.

Entrevistado: Eu tenho que esperar um deles.... quiser trocar de esporte...

Entrevistadora: Esperar a hora de mudar de esporte né?

Entrevistado: É.

Entrevistadora: Tá bom.

Vou querer saber uma última coisa, Lucas. Não sei se é a última das últimas não, é a última linha. Tem mais alguma coisa que você acha que esse projeto $5^{\text {a }}$ Dimensão mudou em você? Te ajudou?

Entrevistado: Como assim...

Entrevistadora: Tem mais alguma coisa?

Entrevistado: Não.

Entrevistadora: Por exemplo, você disse que aprendeu a ter mais paciência?

Entrevistado: É.

Entrevistadora: Foi aqui que você aprendeu. Usar a Internet, ver os jogos na Internet, ler umas palavras novas, que a gente já viu. Tem alguma coisa mais?

Entrevistado: Fazer amizade com todos.

Entrevistadora: Eu concordo com você, eu também acho.

Entrevistadora: E você acha que hoje, depois de ter começado a vir aqui na $5^{\text {a }}$ Dimensão, você faz essas amizades e tem essa paciência de esperar as coisas em outros lugares?

Entrevistado: É.

Entrevistadora: Na escola, em casa, você acha que sim?

Entrevistado: Sim, eu acho.

Entrevistadora: Onde?

Entrevistado: $\mathrm{Na}$ escola, em casa.

Entrevistadora: Legal, muito bom. Ótimo, muito obrigada, tá, Lucas, valeu. Para onde você vai agora?

Entrevistado: Para a 5D, esporte.

Entrevistador: Você lembra o que é hoje? 
Nome: E

Unidade: BSB - LN

Entrevistador: Elder, hoje nós vamos conversar sobre você, sobre as coisas que você aprendeu, sobre coisas que você viveu. Você lembra como você era quando chegou aqui?

Entrevistado: não.

Entrevistador: Você não se lembra não?

Entrevistado: não.

Entrevistador: quando você começou a Quinta Dimensão... As pessoas diziam que você tinha algumas dificuldades, assim, o que era?

Entrevistado: às vezes, quando eu fazia atividade, eu demorava muito para saber como é que era a atividade.

Entrevistador: Ah, você melhorou hoje ...e o que mais? E você ficava na atividade?

Entrevistado: “Ahnn"?.

Entrevistador: e você ficava na atividade?

Entrevistado: um pouco porque às vezes eu não tinha muito interesse.

Entrevistador: não tinha interesse né?... E você fazia o quê nesse momento?

Entrevistado: quando... como assim?

Entrevistador: quando você não tinha interesse, tinha dificuldade de entender o que era para fazer, o que é que acontecia?

Entrevistado: eu fazia a atividade e não participava.

Entrevistador: não participava né? e você ficava mudando de uma coisa para outra?

Entrevistado: sim.

Entrevistador: é, né? Como é que era no Labirinto, você lembra? Como era?

Entrevistado: no Labirinto tinha algumas atividades que eu gostava e não. Às vezes tinha umas que eu não gostava e aí eu ficava mudando de sala. Tinha uma que eu ficava dois, três dias lá, aí até quando o labirinto ficou chato e aí deu uma idéia para o Og@MM para procurar mais jogos.

Entrevistador: foi, né? e você conseguia se lembrar de tudo o que você tinha para fazer? Entrevistado: como assim, no jogo?

Entrevistador: no jogo, mesmo no jogo. Você conseguia se lembrar de um dia para o outro, você lembrava das atividades?

Entrevistado: sim, porque "tipo", lá era assim... todo mundo podia dar uma sugestão e aí às vezes eu dava, alguém dava, de jogar o vídeo game do (termo incompreensível), aí tipo o Og@MM jogava com a gente, até que ele me deu um cronômetro e o "negócio" para dizer o horário e o tempo. Até que foi legal.. 
Entrevistador: foi legal e aí até que você se interessou mais pela atividade né? e, Euder, você lembra como é que era às vezes quando você estava no computador e algum estudante falava com você?

Entrevistado: Lembro!

Entrevistador: o que você fazia?

Entrevistado: às vezes, tem vezes que eu presto mais atenção no jogo do que no estudante.

Entrevistador: hum, isso mesmo

Entrevistado: e às vezes eu parava para conversar com eles...

Entrevistador: e às vezes nem parava né?

Entrevistado: é...

Entrevistador: então você às vezes tinha dificuldade de entender as coisas, né? demorava um pouco, você conseguia lembrar de algumas coisas, né? e às vezes você não falava muito com estudante né?

Entrevistado: é!

Entrevistador: você lembra se tinha facilidade ou não, como é que era na hora em que você tinha que fazer alguma escolha?

Entrevistado: quando eu fazia alguma escolha, "tipo", tinha umas atividades que eu escolhia fora do Sarah, na quadra, na piscina, dentro, só que sempre às vezes foi o pessoal que ficava falando...

Entrevistador: e que escolhia né?

Entrevistado: é!.

Entrevistador: Elder, e hoje você está diferente né? Como você está hoje?

Entrevistado: bem, "de bem com a vida".

Entrevistador: e o que você acha que está diferente hoje para você estar de "bem com a vida".

Entrevistado: O Sarah mudou o meu acompanhamento, que é de esportes, cada mês você faz um esporte. Nesse mês a gente está fazendo canoagem, mas acho que já parou, porque que era só um mês.

Entrevistador: e o que vai ser agora?

Entrevistado: a gente ainda vai decidir.

Entrevistador: mas, olha, antes de começar o esporte você já estava bem diferente, você lembra? Como é que está a 5D, você está conversando mais com os estudantes, menos, como é que tá?

Entrevistado: quando teve aquela troca de estudante até achei que parecia legal, conhecer mais gente, se enturmar mais... até fiquei mais animado assim com a idéia"...

Entrevistador: você começou a ficar mais falante né?

Entrevistado: é! (risos). 
Entrevistador: legal. E você começou a conhecer mais os colegas também?

Entrevistado: sim... muito não porque eram todos velhos, como o Lucas, o Rodrigo, a Betânia....

Entrevistador: já eram amigos?

Entrevistado: é, muito tempo.

Entrevistador: no começo você não falava tanto assim quando a gente tava numa reunião e tal, e hoje você é aí quase um líder do grupo né? você fala, você resolve, você vai lá e marca no quadro. O que você acha, Elder, que aconteceu para você mudar, para você aprender a fazer essas "coisas"?

Entrevistado: praticamente eu não sei o que aconteceu, "tipo" fiquei mais animado com o Sarah, com as atividades, porque antes as atividades eram só labirinto. E aí tinha gente que ficava mudando de idéia no \{termo incompreensível\}, "tipo" para ir passear no barco...

Entrevistador: então você ficou mais interessado em outras atividades, não foi? Agora há pouco a gente falou que você às vezes tinha assim.. demorava um pouco para entender uma atividade e ficava pulando de uma sala para outra no Labirinto.

Entrevistado: era.

Entrevistador: e agora? No ano passado, como é que estava, você ficava pulando lá ou você já conseguia escolher uma atividade para você fazer e ficar nela?

Entrevistado: eu já conseguia escolher uma atividade ... porque quando eu entrei não tinha muito interesse.... porque quando eu entrei, ficava vendo, achava os nomes ruins, e quando foi experimentar tinha uns jogos bons.

Entrevistador: Ah, você foi experimentar e descobriu muitas coisas boas né?

Entrevistado: tinhas uns jogos de criar zoológico, criar uma família.

Entrevistador: tudo bem. E você acha que foi legal conhecer os estudantes, interagir com eles, foi legal?

Entrevistado: é, né, foi; porque além de você conversar com eles, você pode fazer um monte de coisas, porque você tem que estar aqui na sexta-feira, quartas,.. só que agora é só sexta.

Entrevistador: que pena né? Elder você acha que aprendeu alguma coisa aqui no 5D, além dessas coisas que você está falando né? que você aprendeu a ficar mais no jogo, você escolheu coisas, você experimentou. Tem mais alguma coisa que você aprendeu?

Entrevistado: quando eu entrei no Sarah, eu não gostava muito de conversar, das pessoas, aí, hoje em dia, agora todo mundo é meu amigo.

Entrevistador: você aprendeu isso aqui?

Entrevistado: É.

Entrevistador: que coisa boa, você aprendeu até falar com o Og@MM que no começo você não gostava muito dele. E você acha, Elder, que você ainda está aprendendo 
alguma coisa, nesse grupo novo que você está de esporte, como você acha que está no grupo?

Entrevistado: Tô, porque quando você faz um esporte, você tem mais confiança em você, acredita mais em você... que é legal o esporte.

Entrevistador: acho que eu vou lá também (risos).

Entrevistado: risos.

Entrevistadora: você ficou com mais confiança em você? Que legal...E você acha que se sente mais confiante Elder, aqui no grupo, na Quinta Dimensão-esporte ou você acha que ficou mais confiante também lá na escola, em casa, em outros lugares que você vai?

Entrevistado: quando começou esse ano, eu falei para mim que poderia ser uma melhor pessoa, é, né? Até fui melhorando minhas notas, com 7 em matemática, ciências. Aí quando comecei a passar fiquei gostando mais do Sarah.

Entrevistador: e o Sarah também gosta mais de você, não porque você tirou notas boas, mas a gente gosta mais de você. Então está bom, Euder. Tem mais alguma coisa que você gostaria de dizer?

Entrevistado: não.

Entrevistador: sobre você... tem alguma coisa que você descobriu aqui dentro que você gosta? Coisas que você nunca tinha feito...

Entrevistado: quando eu entrei aqui tinha um monte de atividades, atividade que eu não tinha feito, que eu nunca tinha conhecido, muitas... "tipo" esse negócio de canoagem, eu nunca fiz canoagem e comecei a gostar.

Entrevistador: e vai ter outras coisas que você vai descobrir..

Entrevistado: é!

Entrevistador: eu falei agora há pouco que eu acho que você tem um potencial de líder, vejo que você gosta de estar no grupo, de ajudar a resolver as coisas. Você acha isso também ou não?

Entrevistado: como assim?

Entrevistador: você acha que tem capacidade para organizar o grupo, para propor uma atividade e tal?

Entrevistado: é, às vezes quando fico muito animado, eu faço isso, converso com as pessoas de uma atividade.

Entrevistador: e você acha que também pode ser assim na escola, Euder?

Entrevistado: sim, porque você aprende mais, vai aprender mais na escola.

Entrevistador: e você pode também falar mais com seus amigos, propor atividade... Então está bom. Quer dizer mais alguma coisa?

Entrevistado: não. 
Nome: B

Unidade: BSB - LN

Entrevistadora: A gente hoje queria saber de você, como você está hoje? Você veio, ficou internada um tempo, como é que você acha que está hoje?

Entrevistada: Hoje eu acho que eu tô... é claro, eu ia tá pior? Eu acho que me ajudou muito, tanto no colégio, eu tô bem melhor no colégio, acho que agora eu tô conseguindo...não é bem mais inteligente, não vou usar isso, eu não sou burra, claro, sou inteligente, tudo bem, eu tô pegando as coisas mais rápido, tô me organizando bem, hoje eu tô ótima.

Entrevistadora: Tá bem?

Entrevistada: Tô bem.

Entrevistadora: Você lembra Bruna, que você tinha, assim, às vezes uma dificuldade de memória, para se lembrar de alguma coisa, você lembra disso?

Entrevistada: Passei a fazer o que vocês me falaram, pegar um bloco de folha e colocar onde eu vejo mais, entendeu, onde eu vou mais, no meu quarto, essas coisas. Esqueço umas coisinhas de vez em quando, mas lembro quase tudo já.

Entrevistadora: Mas vai né?

Entrevistada: Hum hum.

Entrevistadora: Você usa agenda?

Entrevistada: Uso.

Entrevistadora: Isso também foi orientado para você na época né?

Entrevistada: Hum hum.

Entrevistadora: Você participou da quinta dimensão né, e essas questões para guardar as coisas, para você ter mais facilidade para lembrar, para descobrir essas estratégias, você acha que isso te ajudou?

Entrevistada: Ajudou.

Entrevistadora: Como?

Entrevistada: Me falando como poderia, as coisas que iam me ajudar. Passei a fazer e me ajudou.

Entrevistadora: Foi?

Entrevistada: Foi.

Entrevistadora: Aqui no projeto, tinham coisas que às vezes eram mais difíceis de lembrar?

Entrevistada: Tinha, normal. 
Entrevistadora: Tinha. E como você fazia para lembrar?

Entrevistada: Deixa eu ver. Acho que eu tinha mais ajuda aqui, das pessoas aqui, acho que eu procurava por elas.

Entrevistadora: É.. você procurava alguém e as pessoas faziam o quê? Te davam uma dica, te davam a resposta?

Entrevistada: A dica.

Entrevistadora: Te davam dicas né, entendi.

Quando você voltou para a escola, não sei se você lembra, você às vezes dizia para a gente que as amigas, as colegas de sala, não eram muito legais, que.....

Entrevistada: Eu era excluída.

Entrevistadora: É, você se sentia excluída.

Entrevistada: Sim.

Entrevistadora: A partir da sua participação na $5^{\mathrm{a}}$ Dimensão você se sentia assim também?

Entrevistada: Não.

Entrevistadora: Não?

Entrevistada: As pessoas aqui eram diferentes, não eram igual...., eram também mais velhas, mais maduras, sabiam lidar com as pessoas aqui. Aqui é um espaço diferente, o clima aqui é diferente.

Entrevistadora: E você acha que essa convivência aqui ajudou você naquela época para conviver na escola?

Entrevistada: Ajudou.

Entrevistadora: É?

Entrevistada: Oh. Eu acho que também hoje eu coloquei uma coisa na minha cabeça de que não vou esquentar com isso, tô no colégio para estudar, a minha mãe cansou de falar comigo, e eu coloquei na cabeça. Se viesse uma amiga que eu gostasse, beleza, hoje eu tenho uma amiga lá do Dom Bosco, que entrou no ano passado lá, a Beatriz, a gente sempre se fala, ela vai na minha casa, é difícil ela ir na minha casa, a mãe dela é meio "cri-cri". Eu vou sempre na casa dela, nunca deixei de falar, mesmo eu saindo para outro colégio, então, aquela coisa, somos amigas hoje.

Entrevistadora: E tá legal?

Entrevistada: Já é amiga suficiente para eu ser feliz, entendeu? Beleza.

Entrevistadora: Entendi. E você estava falando, assim, que essa coisa para lembrar das coisas, que você agora anota no papel e tal, tem alguma coisa que você aprendeu que você se lembra, na $5^{a}$ Dimensão, que você acha que te ajudou naquela época?

Entrevistada: Que eu lembro?

Entrevistadora: Não sei, às vezes um jogo, uma atividade, alguma coisa assim.. 
Entrevistada: Eu acho que os jogos também me ajudaram muito naquele raciocínio. Hoje o meu raciocínio está muito bom.

Entrevistadora: Tá legal?

Entrevistada: Tá, tá legal. Também tinha os jogos em que eu tinha que interpretar também eu tô.....tô boa, não, ótima, mas tô boa.

Entrevistadora: Tá bem?

Entrevistada: Dá para viver...

Entrevistadora: Tá legal...

Você tá no $1^{\circ}$ ano do Ensino Médio né, que a sua mãe falou. Como é que você acha que está, assim, em sala de aula, você consegue prestar atenção, escutar o que o professor fala, aprender, como é que está isso:

Entrevistada: Sim, porque às vezes também... às vezes uma coisinha que acontece já me chama à atenção, mas eu tô aqui e, opa, peraí, deixa eu ver aqui, de vez em quando. No bimestre lá no colégio, eu não fui bem, eu fiquei em muitas matérias, só que ela falou para eu estudar mais, recuperar essas matérias, e eu estou me adaptando no colégio, é um colégio novo, educação nova, professores novos, tudo novo, então eu estou me adaptando ainda, entendeu?

Entrevistadora: Mas você acha que consegue acompanhar a aula, você percebe quando se distrai em sala de aula?

Entrevistada: Sim.

Entrevistadora: Legal. Isso acontecia quando você estava jogando aqui na 5D, você lembra?

Entrevistada: De vez em quando sim.

Entrevistadora: Você se distraía?

Entrevistada: Sim.

Entrevistadora: E o que vocês faziam, o que o pessoal fazia quando você ficava mais distraída?

Entrevistada: Bruna, presta atenção

Entrevistadora: Alguém te chamava, assim, aí você voltava...

Entrevistada: É.

Entrevistadora: Entendi, tá bom. Qual é a matéria que você gosta hoje?

Entrevistada: Biologia.

Entrevistadora: Biologia. Antes também era biologia né?

Entrevistada: Biologia e agora estou começando a gostar de português, literatura, gramática, achando legal. Também eu gosto muito dos professores, eu adoro. A professora de biologia é mineirinha também, puxa muito o R, então, eu adoro.

Entrevistadora: Legal. E qual é a matéria que você não gosta?

Entrevistada: Química, matemática e física. Não, química e matemática. 
Entrevistadora: São os vilões, né, química, matemática e física.

Entrevistada: Física nem tanto, física é até tranquilo, só que mais mesmo assim é química e matemática. Tô indo bem...

Entrevistadora: Não gosta, mas tá indo bem...

Entrevistada: Tô indo bem.

Entrevistadora: Nessas matérias, você percebe que fica mais distraída do que o normal?

Entrevistada: Por ser a matéria em que tenho mais dificuldade não fico distraída...

Entrevistadora: Você fica mais atenta?

Entrevistada: Fico mais atenta. As matérias que eu não acho muito difícil, nem me chamam mais atenção, é tranquilo, e as matérias eu faço sem dificuldade então... Às vezes muita coisa me chama atenção mais do que quando estou tendo aula com as outras matérias.

Entrevistadora: Como é que é, não entendi? Quando a matéria é mais difícil...

Entrevistada: Eu tenho mais atenção, por ter mais dificuldade, quando a matéria não é muito difícil, eu me dou bem, às vezes eu presto atenção aqui, mas alguma coisinha que acontece eu já olho assim...

Entrevistadora: Então não depende só se você gosta da matéria ou não, é a matéria que você sabe que tem mais dificuldade você acaba prestando mais atenção?

Entrevistada: Sim.

Entrevistadora: Legal, isso é importante.

Entrevistada: Pois é.

Entrevistadora: E você já sabe o que vai fazer de vestibular, ou se você quer ou não fazer vestibular?

Entrevistada: Sim, eu quero fazer engenharia florestal.

Entrevistadora: Que legal.

Entrevistada: Sim. Se eu gostar de biologia também...

Entrevistadora: É uma boa.

Entrevistada: Tem a ver, só que é química também que cai né, por isso também, é tranquilo, eu posso passar, eu não tenho muita dificuldade em química.

Entrevistadora: É, tá bom. E no mais Bruna, como é que está a sua vida social? Você tem saído? Você tem amigas? Como é que está?

Entrevistada: Saio muito, saio mais com a minha amiga Beatriz, a gente sempre combina de ir lá no Pátio Brasil, que lá tem a parte de brinquedos, um monte de coisa, tem carrinho, negócio de fliperama. A gente sempre gosta de dançar no chamado pump, o tapete mágico, e a gente já tem quase 1 ano nesse lance juntas.

Entrevistadora: Que legal.

Entrevistada: Até ela falou um dia né, quando eu estava lá no Dom Bosco no ano passado a gente se conheceu né, a gente sempre ia lá toda segunda-feira dançar lá, ela 
até foi lá no começo desse ano a gente foi pela primeira vez, e até a tia que atendia a gente lá, sempre eu tava lá, né, a gente falava com ela, e a minha amiga chegou lá e ela perguntou "ué, cadê a sua amiga", ela "ah tia, saiu do colégio". Minha amiga até ficou assim e eu "oh meu Deus, calma amiga", e tem esses lances. Se enche demais a gente vai para o Codama, você conhece o Codama?

Entrevistadora: Não.

Entrevistada: Uma exposição de desenhos, sabe aqueles desenhos chineses..

Entrevistadora: Ah, sei.

Entrevistada: É, mangá, naruto... ela gosta. A primeira vez que eu fui foi no ano passado com ela, e a gente foi de novo esse ano.

Entrevistadora: Legal.

Entrevistada: Tem um monte de coisa lá. Lá tem aquele joguinho guittar hero, que a gente sempre joga lá em casa...

Entrevistadora: Você sai mais com a Beatriz ou tem outras amigas?

Entrevistada: Saio mais com a Beatriz.

Entrevistadora: Sai mais com a Beatriz...

Entrevistada: Em amigas, assim, saio mais com a Beatriz...

Entrevistadora: Mas tem outras amigas?

Entrevistada: Tem, tem sim. Poucas, mas tem.

Entrevistadora: É? Tá bom então.

Entrevistada: O melhor é com a Beatriz mesmo.

Entrevistadora: É, sempre tem uma amiga mais preferida né...

Entrevistada: Mesmo a gente morando em sentidos contrários, porque ela mora lá no Paranoá e eu em Taguatinga...

Entrevistadora: Nossa....

Entrevistada: Sei lá, onde o vento faz a curva entendeu, meio longe...

Entrevistadora: E aí tem que marcar de vez em quando... E vocês conseguem organizar isso.

Entrevistada: Sim.

Entrevistadora: Muito bom. Tá bom então. 
Nome: MB

Unidade: BSB - LN

Entrevistadora: A gente queria ouvir um pouquinho de você hoje sobre como você considera que você era antes. Lembra que você quando chegou aqui você tinha dificuldade, quando tinha muita coisa pra fazer, que ficava preocupada. Como era?

Entrevistadora: Você falava que tinha compromisso no final de semana e ficava assim.... Entrevistada: cheia de....

Entrevistadora: Meio confusa. Como era isso?

Entrevistada: eu ficava estressada, não sabia como organizar. Ficava muito nervosa e chorava por qualquer motivo.

Entrevistadora: Você chorava um bocado, né?

Entrevistada: qualquer coisinha eu começava a chorar.

Entrevistadora: Você lembra das coisas com as quais se preocupava?

Entrevistada: ah... não.

Entrevistadora: Você se candidatou para representante. E aí?

Entrevistada: aí, ao mesmo tempo em que eu fiquei feliz, eu fiquei muito preocupada, né. Porque tinha que ir lá à frente. Alguns ignoravam e ficavam enchendo o saco e depois que o diretor conversou com a turma, que eles tinham que aceitar, eu fiquei meio calma, mas quando foi ontem, teve conselho de classe da minha turma e a professora foi falar que tinha uns bagunceiros lá e tal e que teria que mudar ele de lugar. Falou um monte de coisa e a representante vai ter que ser mudada e aí na hora me deu um frio no coração. Eita. E agora? Vai ter gincana na escola da festa junina, quem levar mais garrafinhas de Coca e vai para o clube e eu estava incentivando a turma. Só que eu passei perguntando e ninguém tinha trazido, falando "não eu esqueci e vou trazer na segunda" e eu "não. Tranquilo". Aí assim, por causa da escola, às vezes não se interessa muito de apoiar nas atividades.

Entrevistadora: E aí você ficou preocupada com essas coisas?

Entrevistada: e aí na hora de ir lá na frente pra dar o aviso, a minha voz não sai e quando eu grito, por qualquer coisinha, a voz sai e fico "ah" e, quando eu vou dar um aviso, ninguém entende e parece que alguma coisa prende aqui na garganta.

$\mathrm{Na}$ hora, eu estava sentada e deu aquele frio, assim. Aí do nada, eu comecei a me preocupar e ficar descendo lágrima, igual a antes e eu não consigo controlar e vai descendo e eu vou pensando e aí tudo o mais vai... e eu não consigo.

Entrevistadora: Mas isso, Betânia, hoje você acha que é mais difícil do que antes ou é igual?

Entrevistada: acho que muitas coisas.... não... eu não vou pirar não. Muitas coisas mudaram pra melhor, é claro. Antes eu reclamava de muita coisa. Antes eu não conseguia, sei lá, organizar o que tinha que fazer e o momento certo. Agora não, eu estou mais tranquila. Assim, eu não estou levando tanto dever pra fazer em casa. Eu estou conseguindo adiantar tudo na escola, na sala de aula. Essas coisas assim. 
Entrevistadora: Você ainda fica muito ansiosa com essas coisas que têm que ser feitas? Entrevistada: acho que em parte sim.

Entrevistadora: É?

Entrevistada: Algumas coisas. É igual à professora mandou a gente fazer uma música de superação e eu falei pra menina na quinta-feira: "você traz a música". Até uns dias antes, que tinha que digitar a música pra professora colar no mural e aí eu falei "... você passou a música para o papel" e ela respondeu: "não. Eu perdi a folha" e eu fiquei um pouco preocupada. Quando foi ontem, eu falei "... você traz" e ela "tá bom" e hoje, quando ia ter aula da professora eu falei "... você trouxe? E ela disse "não" e eu "ta bom" e parece que meu coração meio que dá aviso pra não se preocupar. Aí acabou que no último horário, fizeram uma festinha pras professoras de Dia das Mães e não teve essa aula.

Entrevistadora: Entendi. Deixa só eu fazer um teste aqui Betânia.

Entrevistada: Volta aí um pedacinho, pra eu ver se está.

Entrevistadora: Me diz uma coisa. Você sente que antes, você ficava ansiosa antes de fazer as coisas e depois, você fazia numa boa?

$-\ldots$

Entrevistadora: Você diz que ficava apreensiva quando tinha dever e ainda tinha as coisas de casa pra fazer. E depois, quando você ia fazer, quando começava a fazer, você conseguia fazer numa boa?

Entrevistada: Depende... assim, do dever como era. Às vezes tem assim, de última hora. Você copia de um colega ou então, consegue numa boa, sem correria. Agora, eu consigo, mesmo um dever, pra amanha, eu levo pra casa, mesmo chegando da escola parque à noite, eu faço tranquila e se não dou conta...

Entrevistadora: Você está mais tranquila?

Entrevistada: Estou. Não estou mais tanto assim que fica doendo o dia todo de tanta preocupação.

Entrevistadora: Se você não dá conta, o que você faz?

Entrevistada: Eu peço ajuda das professoras da sala de apoio ou pra alguém que entendeu e então, me ajuda. Eu estou sempre com o dever na hora e coisa assim.

Entrevistadora: Então, antes, quando você estava ansiosa, você chorava, né? Hoje, você já consegue ficar mais tranquila e pedir ajuda a alguém?

Entrevistada: é.

Entrevistadora: Betânia, o que aconteceu pra você chegar nesse ponto hoje? O que você aprendeu com essas coisas? O que você acha e como você acha que aprendeu tudo isso? Entrevistada: Acho que esperando cada dia e que as coisas não mudam tudo de uma vez. Fui frequentar Unção do reino. Lá dão muito discurso pra gente não ficar preocupado com o dia de amanhã. Está ... essas coisas assim. Pra não ficar ansioso pelo dia de amanhã e também por conversar com pessoas que estão dando conselhos e outras formas de pessoas ligarem e você tira que é de proveito. 
Entrevistadora: Na quinta dimensão, às vezes você dizia que tinha que fazer o dever e que queria brincar. Você conseguiu aprender alguma coisa? Essa experiência te ajudou? Entrevistada: Acho que ajudou.

Entrevistadora: Como?

Entrevistada:

Entrevistadora: Noutro dia, você falou, no grupo de esporte que "quem levava a sério, melhorava". Não foi? Na quinta dimensão? Lembra disso que você falou?

Entrevistada:- sim.

Entrevistadora: Por que você falou?

Entrevistada: Que se você leva a sério alguma coisa, se você vai fazer pra dar certo, é melhor, assim, com vontade. Agora, se você faz só por fazer, né? Aí acho que não dá.

Entrevistadora: $\mathrm{O}$ que você acha que experimentou na quinta dimensão que te ajudou? Entrevistada: acho que o convívio com outras pessoas, com os estudantes. Ah. Muita coisa que eu não estou lembrando.

Entrevistadora: O que tem nesse convívio? Em que esses estudantes te ajudaram?

Entrevistada: Ah! Sei lá. Acho que a forma de toda vez chegar e cumprimentá-las e ter que conversar e cada sexta-feira ou quarta-feira com uma pessoa diferente, que ia conversando e ia conhecendo um pouco mais.

Entrevistadora: Elas ajudavam a se organizar? Ou você acha que aprendeu isso sozinha? Entrevistada: Eu acho que, nas primeiras que eu estava participando, que eu conversava e ajudava, mas a maior parte foi eu sozinha.

Entrevistadora: Foi experimentando coisas? Fazendo?

Entrevistada: sim. Tentando aquele que a Carol fez pra mim. Eu não fui seguindo olhando, mas decorei, pois não ia ficar seguindo um roteiro de um jeito, mas da forma que...

Entrevistadora: O que a Carol fez com você? Foi um roteiro?

Entrevistada: aquele roteiro. Não sei se você lembra.

Entrevistadora: Não sei.

Entrevistada: Um roteiro em que, de manhã, acordava, arrumava a cama, tomava café e depois ia ajudar a minha mãe a arrumar a casa, ajudar a fazer comida ...

Entrevistadora: Foi parecido com o que a gente fez no ano passado. Da agenda. Você se lembra?

Entrevistada: Lembro. Aquilo foi muito importante. Bem legal. Acho que aquilo me ajudou muito, porque, apesar de ser uma agenda grande e em quadradinhos, você olha tudo, está bem visível, você anota ali, sem preguiça. Deixa eu ver o que mais.

Agora, todo sábado, eu acordo de manhã, tomo café ou vou comprar o pão e já vou direto fazer as coisas. Ajudar a minha mãe a lavar a área, que eu sempre gosto de, pela 
manhã, lavar a área e vou ajudando. Meio-dia almoço e à tarde fica livre pra o que eu quiser fazer. Antes, à tarde, eu ajudava a minha mãe e era tudo bagunçado.

Entrevistadora: Bem embolado, né? Pelo que você está falando, você aprendeu uma rotina aqui e levou pra sua casa, né?

Entrevistada: é.

Entrevistadora: A rotina aqui, como era? Cumprimentar as pessoas, fazer as atividades, conversar? É isso?

Entrevistada: era viver em grupo. Dar sugestões, que aí eu falava mais. Não é tanta gente assim e o que você falar, ninguém vai rir, às vezes, dependendo.

Entrevistadora: Aí fica mais fácil de você conversar com as pessoas, né?

Entrevistada: é.

Entrevistadora: Você antes tinha medo de que as pessoas rissem de você?

Entrevistada: - muito e, até hoje, mas isso melhorou.

Entrevistadora:Melhorou?

Entrevistada: é, porque o povo é chato. Não tem lugar melhor do que quando venho aqui pro SARAH ou para o CTEF, pois eles são muito engraçados, apesar de serem meninos igual ao Rodrigo, a gente se diverte muito. Não é? Porque você vai para a escola, todo mundo é careta e não cumprimenta. Agora, lá no CTEF eu faço intimidade com todo mundo, apesar de não ir muito.

Entrevistadora: Aqui no SARAH, de vez em quando e é até bom que o seu pai saiba disso. Você que organiza as atividades, você quem chama as pessoas. É ela quem tem ideias. Como você se sente aqui, quando tem que falar com as pessoas?

Entrevistada: às vezes, meio tímida, porque na maioria das vezes, elas só escutam. E elas que já são mais experientes do que eu e tiveram essa mesma fase que eu e deveriam dar um monte de ideia e elas ficam caladas, aí eu vou...

Entrevistadora: Mas elas não te dão ideias?

Entrevistada: eita .....

Entrevistadora: Dão algumas ideias? Mas você se sente a vontade pra falar, mesmo que as pessoas só te escutem?

Entrevistada: às vezes, eu fico agoniada, porque eu gaguejo muito e atropelo nas palavras. É igual, às vezes eu estou conversando aqui, eu quero falar e perco a paciência comigo mesma.

Entrevistadora: É mesmo?

Entrevistada: é igual na frente da sala de aula. Eu começo a embananar as coisas $\operatorname{assim} .$.

Entrevistadora: Você se enrola, né?

Entrevistada: sim. 
Entrevistadora: Tá bom, Betânia. Você acha que seria importante pra você continuar no projeto?

Entrevistada: Sim.

Entrevistadora: Por quê?

Entrevistada: porque é uma oportunidade e, não só por isso, mas sei lá, muitas coisas. Pelo motivo de eu estar cada vez mais melhorando, tendo o apoio de vocês. Deixa eu ver o que mais. Por eu me sentir feliz quando venho pra cá, mesmo morando longe e essas coisas assim. Porque eu mudei muito e acho que cresci muito aqui. Imagine só se eu não tivesse a oportunidade, eu não seria quem sou hoje.

Entrevistadora: Quem você é hoje?

Entrevistada: sei lá.... Ah! Meu Deus! Acho que eu sou uma menina mais madura, não sei. Em algumas partes. Acho que eu estou crescendo mais. É como a professora disse: "isso é porque você está crescendo, você está vendo mais. Está se preocupando".

Entrevistadora: Você acha que hoje consegue resolver melhor os seus problemas? Entrevistada: com certeza. Porque antes, era aquela correria, aquele estresse. Às vezes, era como um estresse que se não houvesse aquela correria, não era nada. Tinha que ter aquela coisa assim.

Entrevistadora: E hoje, você está mais tranquila?

Entrevistada: estou e apesar de muita coisa ter mudado. Sei lá, ter ficado quase tudo mais fácil. No sentido de .... antes, eu me estressava muito por questão de pegar o ônibus, pois o ônibus demorava demais e, agora, estudando aqui na escola na W3, está passando na hora certa. A hora de sair, pra ir pra escola. Mesmo quando estou atrasada pra chegar na escola, dependendo do horário, vou tranquila. Eu não tenho mais aquela euforia, como eu tinha antes, pra tudo. Aquela coisa assim. Igual ao que uma professora disse hoje: "você é uma ótima representante". Quem disse isso: "não sofra antes. Quem sabe tem um motivo", essas coisas assim. E olha que, entre todas as representantes da $8^{\text {a }}$ série, agora lá na escola está com esse negócio de formatura de $8^{\mathrm{a}}$, a única que foi atrás da diretora fui eu, pra conversar com ela, me informar e eu ficava agoniada, porque que quem tem que dar o primeiro passo é a escola. A turma dá um monte de sugestão, mas às vezes não pode concordar antes da direção ver o que eles querem, o que vai ser.

Entrevistadora: Você fez bem em procurar a direção da escola.

Entrevistada: mas às vezes eu penso assim: "poxa, eu acho que não dá pra ser representante de turma, pois representante fala alto, como Coronel e eu não consigo. Outra coisa é que, na maioria das vezes, eu me sinto meio burra na sala. Aí, às vezes eu penso que se eu não fosse representante, eu estaria quieta e calada, sem falar nada e seria bem melhor.

Entrevistadora: Betânia, quando você está aqui, como por exemplo, no Grupo de Esporte, quando vocês têm que decidir alguma coisa, escolher (vocês escolheram a canoa), você foi uma das que tomou a frente, falou, conversou, convenceu as pessoas. Como você se sentiu nesse momento? Você ficou feliz com você mesma? Achou que foi tranquilo? 
Entrevistada: na hora, eu fiquei feliz, porque, imagina se eu não tivesse tomado. Eles iam ficar lá perdendo tempo e uma coisa que eu não agüento é, quando tem um dever, às vezes vou fazer um dever com a professora, eu quero na hora aquilo dali, se é agora, é agora, eu não vou ficar esperando não.

Entrevistadora: Foi legal então você ter conversado com os colegas?

Entrevistada: também é bom, porque são poucos e concordam. Agora, comparar com 34 cabeças na sala, que tudo...

Entrevistadora: Mas é bom porque você experimentou aqui, né?

Entrevistada: É. 